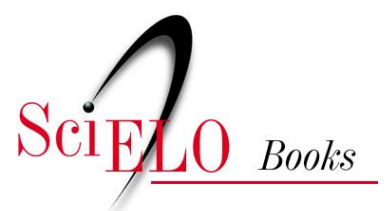

\title{
Partidos, ideologia e composição social
} um estudo das bancadas partidárias na Câmara dos Deputados

\author{
Leôncio Martins Rodrigues
}

\section{SciELO Books / SciELO Livros / SciELO Libros}

RODRIGUES, LM. Partidos, ideologia e composição social: um estudo das bancadas partidárias na Câmara dos Deputados [online]. Rio de Janeiro: Centro Edelstein de Pesquisas Sociais, 2009, 186 p.

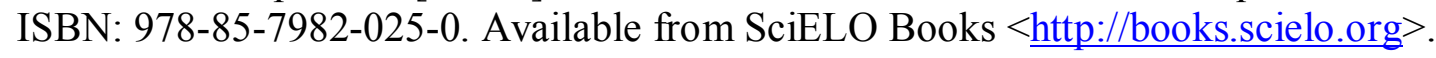

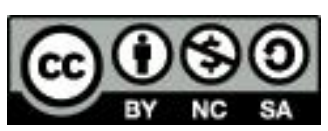

All the contents of this chapter, except where otherwise noted, is licensed under a Creative Commons Attribution-Non Commercial-ShareAlike 3.0 Unported.

Todo o conteúdo deste capítulo, exceto quando houver ressalva, é publicado sob a licença Creative Commons Atribuição Uso Não Comercial - Partilha nos Mesmos Termos 3.0 Não adaptada.

Todo el contenido de este capítulo, excepto donde se indique lo contrario, está bajo licencia de la licencia Creative Commons Reconocimento-NoComercial-CompartirIgual 3.0 Unported. 


\section{BIBLIOTECA VIRTUAL DE CIÊNCIAS HUMANAS}

\section{PARTIDOS, IDEOLOGIA E COMPOSIÇÃO SOCIAL}

\section{Leôncio Martins Rodrigues}

Tentro edelstein de pesquisas sociais 
Esta publicação é parte da Biblioteca Virtual de Ciências Humanas do Centro Edelstein de Pesquisas Sociais - www.bvce.org

Copyright (c) 2009, Leôncio Martins Rodrigues

Copyright (C) 2009 desta edição on-line: Centro Edelstein de Pesquisas Sociais Ano da última edição: 2002

\title{
Partidos, Ideologia e Composição Social
}

Um Estudo das Bancadas Partidárias na Câmara dos Deputados

\author{
Centro Edelstein de Pesquisas Sociais \\ www.centroedelstein.org.br \\ Rua Visconde de Pirajá, 330/1205 \\ Ipanema - Rio de Janeiro - RJ \\ CEP: 22410-000. Brasi \\ Contato: bvce@centroedelstein.org.br
} proprietários dos direitos autorais. A publicação ou partes dela podem ser

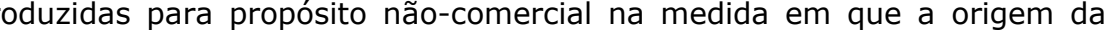
publicação, assim como seus autores, seja reconhecida.

ISBN 978-85-7982-025-0

Rio de Janeiro

2009 


\section{SUMÁRIO}

Lista de tabelas

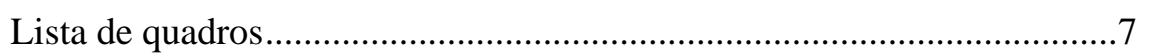

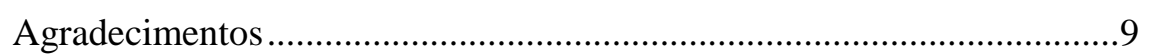

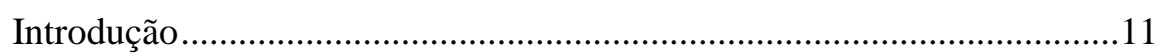

1. Os partidos brasileiros representam algo? .............................................16

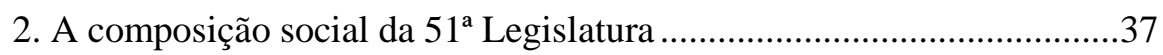

3. Ocupação, profissão e ideologia ........................................................4

4. Patrimônio, partido e ocupação ...............................................................59

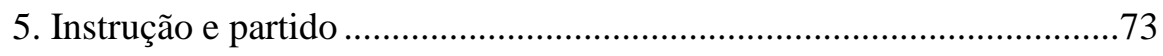

6. As profissões para a política................................................................... 84

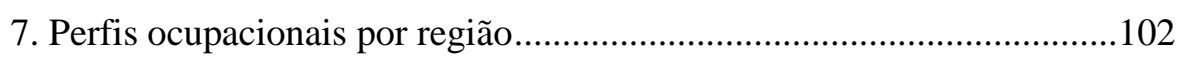

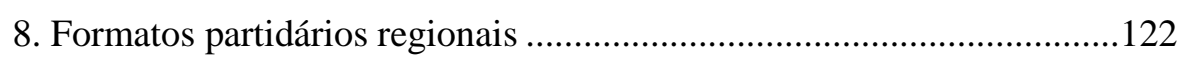

9. Em direção da estabilização?...............................................................143

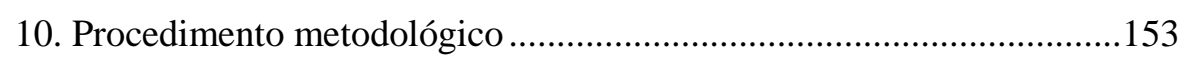

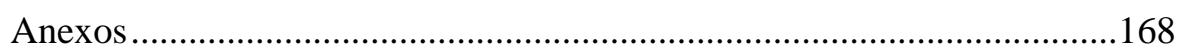

1. Profissões/ocupações desagregadas por bloco ideológico (\%)....168

2. Profissões/ocupações desagregadas por partido............................169

3. Profissões/ocupações desagregadas por patrimônio......................170

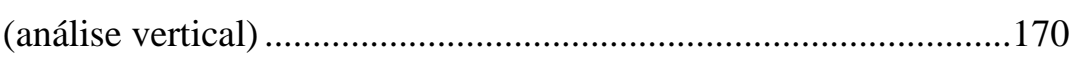

4 - Profissões/ocupações desagregadas por patrimônio....................171

(análise horizontal) ....................................................................171

5. Patrimônio por unidade da Federação ..........................................172

6. Deputados por Estado (51ª Legislatura - Eleição de 1998) .........173

7. Fragmentação e partidos efetivos por Estado................................175

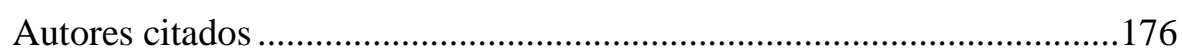




\section{LISTA DE TABELAS}

1. Principais grupos de profissões/ocupações por bloco ideológico (\%)...47

2. Principais grupos de profissões/ocupações por partido (\%) ....................48

3. Distribuição interpartidária do patrimônio ..............................................62

4. Faixas patrimoniais por profissões/ocupações agregadas.......................64

5. Principais profissões/ocupações agregadas por patrimônio......................65

6. Patrimônio por número de legislatura......................................................67

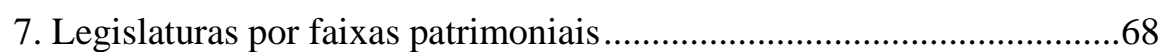

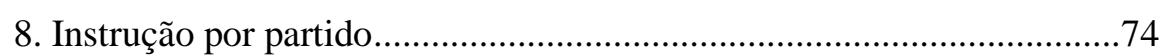

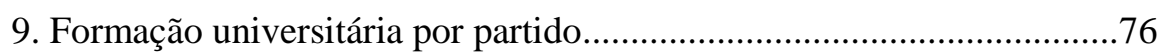

10. Profissões/Ocupações por região (\%) ...................................................105

11. Norte Novo: profissões/ocupações (n.a.) ...........................................107

12. Norte Antigo: Profissões/ocupações (n.a.) ..........................................108

13. Região Norte - Principais categorias ocupacionais agregadas (n.a.)

14. Região Nordeste - Profissões/ocupações ....

15. Região Nordeste - Principais categorias ocupacionais agregadas (\%)

16. Região Sudeste - Principais categorias profissionais (\%).

17. Região Sudeste - Principais categorias ocupacionais agregadas (\%) .115

18. Região Sul — Principais categorias ocupacionais agregadas (\%).......116

19. Região Sul - Categorias profissionais (n.a.).

20. Região Centro-Oeste - Principais categorias ocupacionais agregadas (\%) 118

21. Principais ocupações agregadas por região (\%) . .120
22. Proporção de cadeiras obtidas pelos partidos em cada região (\%) ..... 123

23. Índices de representação dos partidos nas regiões. 127

24. Cadeiras obtidas pelos partidos por região (\%) 128

25. Norte Novo - Cadeira por partido (n.a.)... 130

26. Norte Antigo - Cadeira por partido (n.a.). 130

27. Região Nordeste-Maiores colégios — Cadeiras por partido (n.a.) . 133

28. Região Nordeste - Pequenos colégios - Cadeiras por partido (n.a.)

29. Região Sudeste - Distribuição das cadeiras por Estado (\%)

30. Região Sul - Distribuição das cadeiras por Estado (\%).

31. Região Centro-Oeste — Distribuição das cadeiras por Estado (\%).... 142

32. Evolução dos seis partidos na CD. 146

33. Distribuição dos blocos ideológicos nas regiões e na CD (\%) (todas as legendas incluídas).

34. Índices de representação dos blocos ideológicos nas regiões .

35. Evolução dos blocos ideológicos (\%) 150 


\section{LISTA DE QUADROS}

1. Cadeiras por partido na $\mathrm{CD}$ .15

2. Distribuição das profissões/ocupações desagregadas na Câmara de Deputados (\%)

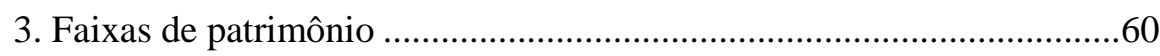

4. Distribuição dos deputados por faixa patrimonial ..................................60

5. Classificação dos partidos nas faixas patrimoniais................................62

6. Patrimônio - de casos na faixa média-alta e na faixa alta .....................66

7. Região Sudeste — Cadeiras obtidas na região (\%) ................................136

8. Região Sul — Cadeiras obtidas por partido (\%) .....................................139

9. Região Centro-Oeste - Cadeiras por partido (\%).................................141

10. Alterações da classificação das ocupações a partir das declarações de bens.

\section{PRINCIPAIS PARTIDOS DA PESQUISA}

PPB - Partido Progressista Brasileiro

PFL — Partido da Frente Liberal

PMDB - Partido do Movimento Democrático Brasileiro

PSDB - Partido da Socialdemocracia Brasileira

PDT - Partido Democrático Trabalhista PT — Partido dos Trabalhadores

PT — Partido dos Trabalhadores

\section{OUTROS PARTIDOS}

PTB - Partido Trabalhista Brasileiro

PSB - Partido Socialista Brasileiro

PC do B - Partido Comunista do Brasil

PPS — Partido Popular Socialista

PL — Partido Liberal

PMN — Partido da Mobilização Nacional

Prona - Partido da Reedificação da Ordem Nacional

PSC - Partido Social Cristão

PSD - Partido Social Democrático

PSL — Partido do Solidarismo Libertador

PST - Partido Social Trabalhista

PV - Partido Verde 


\section{AGRADECIMENTOS}

Embora este texto seja de minha exclusiva autoria, sem o apoio desinteressado de muitas pessoas e instituições, boa parte das análises que seguem não poderia ter sido feita. Devo mencionar especialmente a ajuda que recebi do ministro Costa Porto, então presidente do Supremo Tribunal Eleitoral, e do Dr. Ney Andrade Coelho, então secretário do STE, os quais me possibilitaram o contato com os Tribunais Regionais Eleitorais de todas as unidades da Federação e a obtenção das declarações de bens dos deputados eleitos para a $51^{\text {a }}$ Legislatura. Quero agradecer igualmente aos TREs dos 21 Estados que tiveram a gentileza de me enviar uma cópia das referidas declarações. À Fapesp e ao CNPq, duas instituições de importância inestimável para o desenvolvimento da pesquisa científica em nosso País, devo o apoio financeiro e institucional. A ambas, meu profundo reconhecimento.

A Antônio Octávio Cintra devo a indicação do "caminho das pedras" para a obtenção das declarações de bens dos parlamentares cuja utilidade poderá ser percebida na leitura do texto.

A Maria Tereza Sadek e Fernando Limongi agradeço a atenta e competente leitura crítica dos originais deste livro, assim como as preciosas sugestões de redação e de análise.

De Fernão Dias de Lima, no trabalho de assessoria computacional, contei não somente com a competência, mas com um apoio que foi muito além do simples profissionalismo ao atender com paciência e rapidez às minhas frequentes solicitações de novas tabelas e ao resolver os "pepinos" que iam aparecendo.

A Marcello Simão Branco devo o trabalho de levantamento da bibliografia mais recente sobre a composição do Legislativo e sobre partidos políticos.

Last but not least, não exagero ao dizer que este texto levaria muito mais tempo para ser terminado, e conteria muito mais falhas, não fosse o extraordinário empenho e dedicação de João Carlos da Silva e Maria Liene de Melo nos trabalhos de tabulação, feitura de tabelas, revisão do texto e sugestões de análise. A ambos e a todos acima mencionados quero manifestar meu profundo agradecimento. Obviamente, nenhuma das pessoas e instituições mencionadas tem qualquer responsabilidade por erros e falhas que possam ter ocorrido na tabulação dos dados e na sua interpretação. 


\section{INTRODUÇÃO}

Este trabalho tem como objeto principal a composição social das bancadas na Câmara dos Deputados de seis dos principais partidos brasileiros. Entendemos que os resultados da pesquisa indicaram que há uma relação consistente e coerente entre os meios socio-ocupacionais de recrutamento partidário e as orientações político-programáticas dos partidos na escala ideológica direita-centro-esquerda. Complementarmente, o exame das configurações partidárias resultantes das eleições de 1990, 1994 e 1998 mostrou um quadro multipartidário relativamente estável, com avanços mais fortes das correntes de centro, perdas pequenas da direita e ganhos também pequenos da esquerda.

\section{A operacionalização da pesquisa}

A pesquisa, sobre a qual se baseia este livro, utilizou como principal fonte de informação a publicação Deputados Brasileiros - Repertório Biográfico, do Centro de Documentação e Informação da própria Câmara dos Deputados (CD, daqui para frente), referente à $51^{a}$ Legislatura (19992003), eleita em outubro de 1998. Os parlamentares incluídos na pesquisa e as respectivas legendas partidárias pelas quais foram eleitos são as que constam da referida publicação. Posteriores trocas de legendas ou outras alterações na composição das bancadas partidárias não foram consideradas. Os efeitos das coligações, que possivelmente afetaram os resultados da eleição de 1998 para a CD, também foram ignorados. Interessou-nos a distribuição das cadeiras por partido.

Utilizamos também, como fonte primária, dados retirados de 401 declarações de bens que os candidatos a deputado federal entregaram aos tribunais regionais eleitorais de seus Estados ao solicitarem o registro de suas candidaturas. Todas as análises são feitas em termos quantitativos, expressos geralmente em porcentagem e sem referências pessoais. Trata- se de um estudo informativo, que se pretende, antes de tudo, de natureza estritamente acadêmica. Em nenhum momento houve de nossa parte a intenção de beneficiar ou prejudicar qualquer partido. Mas é possível que alguns trechos possam desagradar a políticos e simpatizantes dessa ou daquela tendência ideológica. Aceitamos que isso possa ocorrer ainda que nosso compromisso tenha sido apenas com o correto levantamento e interpretação dos dados. Não defendemos uma ciência política que se pretenda "engajada", embora aceitemos que o compromisso com a objetividade e o distanciamento valorativo do objeto nem sempre são fáceis de serem alcançados. Talvez sejam mesmo impossíveis, mas acreditamos que é uma meta que deve ser procurada.

No decorrer da exposição, procuramos evitar certos conceitos especializados assim como uma terminologia habitualmente usada pelos cientistas políticos. Procuramos deixar de lado todos os termos e expressões que poderiam tornar este livro de mais difícil leitura para os leigos. Alguns conceitos, porém, não puderam ser evitados, ainda que a intenção deste trabalho seja de oferecer informações tanto para os especialistas como para todos os que se interessam pela política brasileira.

\section{A temática}

A investigação das chamadas "bases sociais dos partidos" aproximase de uma abordagem cara às análises de inspiração marxista que tendem a vincular, de modo dependente, as representações políticas aos interesses das classes sociais ou, quando a análise se sofistica, às frações de classe ou aos estratos existentes no interior das classes. Desse ângulo, nesta pesquisa, o "caráter de classe" dos partidos seria aqui captado, de modo mais empírico, por meio de categorias e subcategorias profissionais e ocupacionais que integram suas bancadas.

Apesar de o tipo de análise e de o tema escolhido nesta pesquisa terem certo parentesco com enfoques marxistas, não segue daí a aceitação de interpretações que passam do social ao político de modo direto e mecânico. Uma das fraquezas desse tipo de análise, que reduz a autonomia do político, deriva de ignorar, ou minimizar, a complexidade das disputas políticas entre os múltiplos grupos de interesses nas democracias de massa, a transformação dos partidos em organizações complexas com interesses específicos e, especialmente, não ver o correlato aparecimento do político 
profissional que irá formar a classe política com valores e objetivos próprios. ${ }^{1}$

Mas, embora rejeitando os esquematismos que tendem a emergir nas análises "classistas" das condutas políticas, a escolha do objeto, as pressuposições, explícitas ou subjacentes da pesquisa, afastam-se também das abordagens de tipo institucional. Na verdade, o enfoque que adotamos e os pressupostos sobre os quais se baseia nossa abordagem estão mais próximos de uma sociologia política do que de uma ciência política stricto sensu, o que não significa que desconsideremos o papel das instituições, leis e regras que envolvem e balizam as tentativas de alcançar o poder por meio da conquista de votos.

Especificamente, lidamos com duas variáveis principais: a composição social das bancadas dos partidos (apreendidas por meio das profissões/ ocupações de seus integrantes) e os partidos focalizados do ângulo de suas bases sociais e regionais. Embora o estudo esteja limitado aos parlamentares de seis legendas, ele fornece informações sobre as fontes de recrutamento da parcela da classe política brasileira presente na Câmara dos Deputados. Entendemos também que os resultados da investigação devem acrescentar novos elementos para a avaliação dos partidos brasileiros. Procuramos captar as diferenças socioprofissionais entre partidos que se alinham em posições diferenciadas no tradicional leque ideológico direita-centro-esquerda. Ficaram para uma futura investigação as relações das orientações partidárias com outras variáveis, como idade,

\footnotetext{
${ }^{1}$ Não pretendemos discutir o conceito de "classe política". Digamos apenas que estamos entendendo por esse termo o conjunto de todos os que, nos sistemas democráticos, vivem não apenas para a política mas da política. Apesar das disputas e variações ideológicas internas, seus integrantes tendem a partilhar interesses comuns, tais como os benefícios materiais e simbólicos usufruídos pelos que têm alguma participação no sistema decisório. É necessário, para tanto, que o poder permaneça em mãos de alguma facção da classe política, mesmo que seja de facção adversária, e não vá para as mãos de um chefe militar, líder religioso, comandante de guerrilha ou secretário-geral de algum partido revolucionário. Certamente, essas observações são muito insuficientes como esforço de definição do conceito. Mas servem para este texto. Os que discordarem mais radicalmente do termo "classe política", leiam, em seu lugar, os políticos.
}

gênero $^{2}$ ou outras, eventualmente significativas para o estudo das orientações programáticas e ideológicas dos partidos.

\section{Os partidos selecionados}

Para o exame da composição das bancadas dos dezoito partidos que obtiveram ao menos uma cadeira na $\mathrm{CD}$, foram escolhidos o PPB, o PFL, o PMDB, o PSDB, o PDT e o PT. Convencionalmente, o PPB e o PFL são classificados pela maior parte dos pesquisadores e pela mídia como partidos de "direita", embora esse rótulo possa não ser de agrado dos seus dirigentes e seja rejeitado por parte de seus membros. O PMDB e o PSDB são convencionalmente considerados de "centro", rótulo que não é negado por seus dirigentes. O PDT e o PT são entendidos como partidos de "esquerda", designação aceita de bom grado pelos seus dirigentes e simpatizantes.

De nossa parte, estaremos usando esses conceitos no sentido convencional. Como muitos outros autores, temos muitas restrições às etiquetas direita, centro e esquerda e dúvidas quanto ao que realmente elas significam nas sociedades contemporâneas. No entanto, neste trabalho, para evitar perder tempo com uma discussão que não é essencial aos nossos propósitos, catalogamos essas legendas de acordo com o senso comum, tal como são entendidas habitualmente pela mídia, pela opinião pública e pela maioria dos cientistas políticos, brasileiros e brasilianistas, que estudam o nosso sistema partidário.

Dois critérios levaram à escolha das seis legendas partidárias: número relativamente elevado de cadeiras conquistadas na $\mathrm{CD}$ (ao menos, cerca de 5\% do total de deputados federais) e um perfil programático-

\footnotetext{
${ }^{2}$ A clivagem de gênero, certamente, é uma das mais importantes, mas não foi investigada agora. Adiantemos, apenas, que para a atual legislatura federal foram eleitas 29 deputadas $(5,7 \%$ da CD). Como se sabe, a participação das mulheres vem aumentando em todos os segmentos do mercado de trabalho. Nas instituições políticas brasileiras, inclusive no Senado, mais "fechado" e conservador, a proporção de senadoras vem crescendo, embora ainda seja pequena. $\mathrm{Na}$ CD, o grande salto veio depois das eleições de 1986, quando 166 mulheres se candidataram e 26 foram eleitas contra 58 e 8 , respectivamente, em 1978. Mas, em comparação com outros setores de atividade, no campo da política, o crescimento da participação feminina tem sido mais lento. (Informações mais abrangentes encontram-se em Avelar (1996), do qual retiramos esses últimos dados.).
} 
ideológico relativamente consistente e nítido. ${ }^{3}$ Contudo, para o exame da evolução dos blocos ideológicos e dos formatos partidários nas circunscrições estaduais, o PTB e outros pequenos partidos foram levados em consideração.

Os seis partidos selecionados para a pesquisa compreendiam $84 \%$ das cadeiras da CD. Tomando como ponto de referência as eleições de 1990, a proporção de cadeiras ocupadas por eles passou de $75 \%$ em 1990 para $84 \%$ em 1998.

Quadro 1

Cadeiras por partido na $\mathrm{CD}$

\begin{tabular}{|c|c|c|}
\hline Partido & Bancada N & $\%$ \\
\hline 1. PFL & 105 & 20,5 \\
\hline 2. PSDB & 99 & 19,3 \\
\hline 3. PMDB & 83 & 16,2 \\
\hline 4. PPB & 60 & 11,7 \\
\hline 5. PT & 59 & 11,5 \\
\hline 6. PDT & 25 & 4,9 \\
\hline Total & 431 & 84,0 \\
\hline Outros partidos & 82 & 16,0 \\
\hline
\end{tabular}

${ }^{3}$ Pelo requisito "número de cadeiras", a rigor, o PDT, com 4,9\% das cadeiras ganhas em 1998, deveria ficar de fora da pesquisa. O PTB, com 6,0\%, seria incluído. Mas tivemos alguma hesitação quanto à inserção, ou não, da bancada do PTB na pesquisa. Essa legenda obteve, em 1998, 31 cadeiras, seis a mais do que o PDT. Do ângulo do critério quantitativo, preenchia uma das condições. Mas seu perfil ideológico não pareceu tão nítido a ponto de possibilitar uma classificação ideológica menos sujeita à controvérsia. Acrescente a esses argumentos o fato de ser seu índice de migração partidária demasiadamente elevado e muito mutável. Na década de 1990,44\% dos seus deputados mudaram de partido. Na legislatura de 1991/1995, entre os 45 deputados que passaram pela legenda do PTB, 22 abandonaram o partido (Melo, 2000, p. 224). Na atual legislatura, em maio de 2001, quando iniciamos a redação deste texto, o PTB estava com 26 deputados, tendo perdido, portanto, cinco cadeiras. Mas em maio de 2002 estava com 34 deputados. Do prisma ideológico, na avaliação da maioria dos pesquisadores, o PTB é colocado no campo da direita; na do DIAP (Departamento Intersindical de Assessoria Parlamentar), é classificado como de centrodireita.

\section{OS PARTIDOS BRASILEIROS REPRESENTAM ALGO?}

Este capítulo divide-se em duas secções: a primeira expõe algumas das críticas mais frequentemente dirigidas ao sistema partidário do País por importantes cientistas políticos brasileiros e brasilianistas. A segunda traz as avaliações mais amenas de outros pesquisadores que, com base em pesquisas mais recentes, concluem que o sistema partidário brasileiro tem mais representatividade, consistência ideológica e disciplina parlamentar do que afirmam os mais críticos.

\section{As críticas}

Entre os cientistas políticos que têm pesquisado o sistema político brasileiro, provavelmente o brasilianista Scott Mainwaring — autor de muitos e importantes estudos sobre o tema - está entre os mais críticos. A ausência de disciplina partidária seria uma das características negativas mais salientes dos nossos principais partidos (Mainwaring, 1993). Para o pesquisador norte-americano, em relação ao seu nível de desenvolvimento econômico, "o Brasil pode ser um caso único de subdesenvolvimento partidário no mundo [...] Os partidos brasileiros, no longo prazo, dificilmente seriam capazes de servir de suporte para a democracia" (Mainwaring, 1995, pp. 354 e 391). Em trabalho mais recente, Scott Mainwaring voltou a acentuar, dessa vez de modo mais aprofundado e amplo, a fraca institucionalização dos nossos partidos, o individualismo e a autonomia dos políticos brasileiros ante sua organização partidária, a predominância dos sistemas de patronagem, do clientelismo e do patrimonialismo (Mainwaring, 1999). Mesmo em comparação com outros países da América Latina, onde as estruturas partidárias seriam frágeis e o papel dos partidos no jogo político mais fraco do que na Europa, o sistema partidário brasileiro estaria entre os últimos em termos de seus índices de institucionalização (Mainwaring \& Scully, 1994).

${ }^{1}$ Contudo, os autores ressalvam que, apesar de organizativamente fracos, com pouco enraizamento na sociedade e predominância das personalidades sobre os partidos (características divididas, na América Latina, com os sistemas partidários da Bolívia, Peru e Equador), os partidos brasileiros teriam "perfis ideológicos relativamente claros no plano das elites" e que não seria "correto afirmar que todos os partidos se assemelham, que não são 
Essas avaliações retomam ideias desenvolvidas há mais tempo por Mainwaring em artigo redigido em colaboração com Aníbal Pérez Lirian sobre a atuação dos partidos na Assembleia Nacional Constituinte (ANC). Os autores insistem sobre o elevado coeficiente de indisciplina partidária de nossos partidos. Apenas os de esquerda se salvariam. Os "níveis de lealdade absoluta [dos constituintes em relação aos seus partidos] demonstram o mesmo padrão geral: partidos de esquerda altamente disciplinados, partidos catch-all ${ }^{2}$ pouco disciplinados e o PDT na posição intermediária" (Mainwaring \& Lifian, 1998, p. 120). Os resultados da pesquisa teriam revelado que os três grandes partidos catch-all brasileiros apresentaram grande variação interna nos níveis de lealdade, fidelidade e coesão. O PMDB seria um dos mais indisciplinados.

Mainwaring e Lifian entendem que o melhor caso para se comparar com o Brasil seria o dos EUA, onde os partidos são mais indisciplinados do que os da Europa Ocidental. Entre 1984 e 1994, a média do nível de disciplina partidária absoluta no Senado norte-americano foi de 78,0\% para os democratas e $77,2 \%$ para os republicanos; na Câmara de Deputados, a média para os democratas foi $80,4 \%$ e para os republicanos, $75,8 \%$. Na ANC brasileira, foi de 53,1\% a 50,9\% (antes e depois de 25 de junho de 1988, quando foi criado o PSDB). Mas, na Constituinte, os partidos de esquerda brasileiros alcançaram, segundo os autores, "níveis de unidade absoluta muito mais altos do que os norte-americanos" (Mainwaring \& Lifian, 1998, p. 127). No geral, e para ficarmos na América Latina, os partidos brasileiros, além de pouco institucionalizados, seriam bem mais indisciplinados do que os partidos da Argentina, da Venezuela e do Uruguai (idem, p. 128).

'verdadeiros` partidos - ou que "são atores sem importância” (Mainwaring \& Scully, 1994, p. 63).

${ }^{2}$ Literalmente, partidos "pegam tudo". O termo, de Otto Kirchheimer, usado para indicar as mudanças nos sistemas partidários europeu após a II Guerra, generalizou-se entre os cientistas políticos. O autor alemão, falecido em 1965, defende a ideia de que os grandes partidos burgueses de representação individual, por um lado, e os partidos socialistas de integração (class-mass parties), por outro, transformaram-se, após a II Guerra, em catch-all parties. Sendo altos os custos das derrotas eleitorais, para chegar ao governo precisam captar votos onde for possível e, portanto não podem ser partidos de uma só classe (Kirchheimer, 1996).
Vale observar, de passagem, que Scott Mainwaring, como outros autores, entende que "sistemas presidencialistas são em geral desfavoráveis para a criação de coalizões [partidárias] estáveis" (Mainwaring, 1993, p. 49). A "ausência de disciplina partidária, característica saliente dos principais partidos, de 1985 para cá", teria "contribuído para o enfraquecimento dos partidos" (idem, p. 64). ${ }^{3}$

Na realidade, a visão negativa do sistema partidário é predominante entre os brasilianistas. Barry Ames, outro pesquisador norte-americano que tem estudado o sistema político brasileiro, chega mesmo a considerar que "no plano nacional, os partidos brasileiros dificilmente poderiam ser considerados partidos políticos" (Ames, 2001, p. 269). Embora de modo mais atenuado e fundado em razões diferentes, vão na mesma direção às considerações de David Samuels sobre a política brasileira (Samuels, 1997) e também as de Frances Hagopian sobre a persistência das formas de política tradicional em Minas Gerais (Hagopian, 1996). ${ }^{4}$

${ }^{3}$ Embora o autor norte-americano, nesse artigo, corretamente chame a atenção para muitos aspectos negativos do funcionamento do sistema político brasileiro, não parece bem resolvida a direção da relação de causa e efeito entre presidencialismo e fragilidade dos partidos. Em algumas passagens, são os partidos indisciplinados e a fragmentação partidária que impedem o presidente de governar; em outras, a relação causal vai na direção inversa. Alguns exemplos: "O sistema presidencialista brasileiro se mostrou inimigo do fortalecimento dos partidos porque os presidentes se veem obrigados a depreciar o Congresso e os partidos" (Mainwaring, 1993, p. 64). Em outras passagens, os principais responsáveis pelo mau funcionamento do sistema político brasileiro são os próprios partidos: "Os partidos brasileiros, nos dois períodos democráticos [anterior e posterior ao golpe militar de 641 , foram indisciplinados e incapazes de oferecer uma base de sustentação estável para os presidentes] (Mainwaring \& Perez, 1998, p. 36)". A partir daí, sendo presidencialismo e partidos igualmente culpados, e o parlamentarismo não podendo funcionar adequadamente, as perspectivas para a continuidade da democracia brasileira não parecem nada boas: "No Brasil, devido à indisciplina dos partidos e à extrema fragmentação partidária, um governo parlamentarista enfrentaria obstáculos desanimadores" (idem, p. 70). "Se permanecem dúvidas acerca da viabilidade do sistema parlamentarista no Brasil, a combinação de presidencialismo, partidos frouxos e um sistema partidário fragmentado mostra-se cada vez mais impraticável” (idem, p. 71). Entretanto, convém assinalar que, mais recentemente, Mainwaring - citando os dados do estudo de Figueiredo e Limongi sobre as votações na Câmara dos Deputados - reconhece o aumento da disciplina partidária após o fim da Constituinte.

${ }^{4}$ O estudo de Frances Hagopian (1996) sobre a persistência de clãs políticos, das modalidades tradicionais e modernas de clientelismo e de novas formas de autoritarismo, 
Apesar de acrescentarem novos enfoques metodológicos e de destacarem aspectos importantes da nossa política, os pesquisadores norteamericanos não têm o monopólio dos diagnósticos negativos e prognósticos pessimistas sobre o sistema político brasileiro e os riscos que partidos fracos e pouco representativos ofereceriam para a estabilidade democrática. Muitas vezes reproduzem juízos já difundidos por cientistas políticos brasileiros, jornalistas, membros da própria classe política e eleitores. ${ }^{5}$

A avaliação de Mainwaring retoma, na verdade, uma ideia já expressada por Bolívar Lamounier e Rachel Meneguello em meados da década de 1980: "Em perspectiva comparada, o Brasil é um caso notório de subdesenvolvimento partidário. Se partirmos do pressuposto de que partidos fortes e bem enraizados na sociedade são indispensáveis à consolidação democrática, nossa discussão deve centrar-se desde o início nessa longa história de descontinuidade e debilidade" (Lamounier \& Meneguello, 1986, p. 9). ${ }^{6}$

Entre as novas democracias latino-americanas - escreveu por sua vez Maria D’Alva Gil Kinzo, outra conceituada analista do sistema partidário brasileiro - o Brasil é o caso mais problemático da experiência partidária. Aqui ainda não assistimos à emergência de um sistema partidário de perfil definido e duradouro. $\mathrm{O}$ presente quadro partidário caracteriza-se por sua mutabilidade, fragilidade e fragmentação [Kinzo, 1993, p. 95].

está limitado a Minas Gerais, mas muitas de suas observações podem ser estendidas para a política brasileira.

Observa Paulo Sérgio Peres, na mais ampla avaliação da bibliografia sobre as interpretações críticas do sistema partidário brasileiro que conhecemos, que "as desconfianças quanto à efetividade da democracia e de suas instituições representativas no Brasil não surgiram de repente [...] e muitas das análises e propostas de reforma política reivindicadas atualmente possuem raízes bem mais antigas" (Feres, 2000, p. 19).

${ }^{6}$ Salienta Paulo Sérgio Feres que "Mainwaring nada mais faz do que sintetizar a análise huntingsartoriana de Lamounier e Meneguello $(1986$, p. 9) que já haviam salientado que a 'complexidade da sociedade brasileira, a razoável modernidade do aparelho de Estado, para não falar no dinamismo da economia, tudo isso forma um contraste intolerável com o evidente subdesenvolvimento das instituições de intermediação política'. Dessa maneira, não Mainwaring (1992), mas Lamounier e Meneguello (ibidem) que merecem crédito pela conclusão de que '[...] o Brasil é um caso notório de subdesenvolvimento partidário - (Peres, p. 89).
Na mesma direção, Olavo Brasil de Lima Jr. entendia, em começos da década de 1990, que os resultados de suas pesquisas levavam a "um quadro bastante sombrio" da natureza da representação parlamentar e que dificilmente se poderia dizer que nós estaríamos diante de um "sistema parlamentar estável" (Lima Jr., 1993a, p. 101). A instabilidade do quadro institucional envolveria todo o sistema político: "Não há dúvida [...] de que o quadro institucional brasileiro é de grande instabilidade, aí incluído o sistema partidário" (Lima Jr., 1993b, p. 62). O autor diagnosticava, pessimisticamente, que o estado dos partidos políticos seria "particularmente alarmante" e que a representação política brasileira estava "passando por grave crise, cujo desenlace é inteiramente imprevisível", estando a "representatividade do Congresso consideravelmente abalada" (Lima Jr., 1993b, p. 26). Obviamente, Lima Jr. não cometeria a ingenuidade de atribuir todos os males do sistema político brasileiro aos partidos, mas, como as citações acima indicam, parte importante das deficiências da representação democrática no País viria do nosso sistema partidário (além, obviamente, das características específicas do sistema eleitoral).

\section{Alguns indicadores}

Mais didática e sinteticamente, os aspectos negativos que, de modo geral, são ressaltados pela ala mais crítica referem-se:

1) Ao excessivo número de partidos, ou seja, à alta fragmentação partidária que começara com a Constituinte. ${ }^{7}$ Entre 1982 e 1994, o número de partidos que concorreu em alguma eleição chegou a 68. Mas o número de partidos legais foi diminuindo. No final de 1995, apenas 23 haviam obtido o registro definitivo (Nicolau, 1996, pp. 14-17).

Entre 1980 e 1994, o número de partidos que concorreu em alguma eleição chegou a sessenta.

\footnotetext{
${ }^{7}$ De fato, a fracionalização partidária e a marcha para o multipartidarismo iniciaram-se já na ANC. Os resultados das eleições posteriores levaram ao aumento do número dos partidos que poderíamos chamar de "partidos de tamanho médio" (Rodrigues, 1995) e ao equilíbrio entre os blocos de direita, centro e esquerda (Fernandes, 1995). Mais diretamente, o declínio do PMDB, a criação do PSDB e a ascensão do PT contribuíram para o aumento do coeficiente de fragmentação.
} 
2) À fragilidade dos partidos, expressa pela descontinuidade em sua existência, meras legendas criadas para atender a projetos pessoais, "partidos" que pouco tempo depois desapareceriam ou perderiam qualquer influência na política brasileira, se é que alguma vez tiveram alguma.

3) Às sucessivas mudanças de partidos por parte dos políticos, aspecto que se vincula à falta de coesão, de disciplina e de fidelidade partidárias. De fato, as rápidas e constantes trocas de legendas mostram índices que impressionam. Entre 1983 e 1987, 31,3\% dos deputados mudaram de partido; entre 1987 e 1991, 27,5\%; entre 1991 e 1999, 26,9\%. Entre 1983 e 1999, de um total de 2329 deputados federais, entre titulares e suplentes, $686(29,4 \%)$, migraram para outras legendas (Melo, 2000, p. 210). Jairo Nicolau, examinando a trajetória dos 513 deputados federais eleitos em 1994, verificou que 64,6\% tinham trocado de partido pelo menos uma vez (Nicolau, 1996, p. 65). Entre janeiro de 1991 e abril de 1993, Carlos Alberto Novaes encontrou 174 trocas de partido (Novaes, 1994, p. 113).

4) À falta de consistência ideológico-programática, fato que possibilitaria coligações eleitorais (notadamente em âmbito municipal, mas também estadual e federal) as mais esdrúxulas, em princípio incompatíveis programaticamente, agregando partidos que em outros municípios ou Estados são adversários. Nesse ponto, seriam paradigmáticos os casos de partidos que competem entre si nos Estados, mas que apoiam, no plano federal, um mesmo candidato a presidente.

5) À patronagem, ao clientelismo e ao patrimonialismo, que seriam, de acordo com Scott Mainwaring (Mainwaring, 1999), os traços mais salientes do sistema partidário e eleitoral brasileiro e teriam sobrevivido, com extensão variada segundo a região, à abertura democrática e às transformações mais recentes da sociedade.

6) Ao individualismo dos políticos, característica que levaria à competição intrapartidária, à predominância das estratégias pessoais sobre as coletivas, à ocultação, quando de campanhas eleitorais, dos programas e, às vezes, das legendas dos partidos, de acordo com os interesses pessoais dos candidatos.

7) À indisciplina partidária, outra marca dos partidos brasileiros, ponto muito difundido na opinião pública e salientado em muitos trabalhos acadêmicos. A tese poupa apenas os partidos de esquerda, os únicos que seriam dotados de alguma consistência organizatória, programática, coesão e disciplina.

Um dos resultados desse "subdesenvolvimento político" seria a profunda instabilidade do nosso sistema partidário, sua incapacidade de representar interesses sociais e, basicamente, de servir de canal de intermediação entre o poder público e a sociedade. No limite, seu mau funcionamento constituiria um fator de risco para a continuidade e a consolidação do processo democrático no País.

\section{Repensando algumas teses...}

Mas apesar de as análises anteriores apontarem para muitos aspectos que, inegavelmente, revelam coeficientes baixos de representatividade, de estrutura organizatória e de coerência ideológica dos partidos brasileiros, um conjunto de pesquisas mais recente começou a questionar os julgamentos mais negativos e pessimistas, mostrando um outro lado do funcionamento do nosso sistema partidário. Esses estudos encontraram partidos com perfis ideológicos mais nítidos e diferenciados, com patamares mais altos de disciplina e de fidelidade partidárias, capazes paradoxalmente de coexistir com altas taxas de migração e fragmentação partidária, corrupção e individualismo de uma parcela ponderável dos políticos. No final, as novas pesquisas permitem indagar se os partidos brasileiros seriam efetivamente a geleia geral, inorgânica, amorfa, incompetente e corrupta, como crê a opinião pública e uma parcela dos cientistas políticos.

Com respeito à atuação dos partidos na Assembleia Nacional Constituinte, por exemplo, o estudo de Ricardo Corrêa Coelho - utilizando uma metodologia diferente da de Mainwaring e Lifian e de outros brasilianistas $^{8}$ - chegou a outros resultados sobre a auto-identificação

${ }^{8}$ As críticas de Ricardo Corrêa dirigem-se não apenas ao estudo de Mainwaring e Lifian, mas também aos de Samuels (1996) e Ames e Power (1990). Mas não seria possíve reproduzir aqui as divergências metodológicas entre Ricardo Corrêa Coelho e os brasilianistas. $\mathrm{O}$ estudo das votações no Legislativo tem mais problemas do que pode parecer para os leigos. Para os fins de nossa pesquisa, a discussão sobre esse ponto não é necessária. Queremos apenas apontar a inexistência de consenso. 
ideológica dos deputados, a disciplina partidária e outros indicadores de consistência e fidelidade partidárias. A partir desses dados, Ricardo Coelho conclui que os partidos políticos representados na ANC, longe de terem sido "organizações artificiais e amorfas, incapazes de representar interesses sociais e de controlar a ação de suas bancadas, foram os seus atores decisivos" (Coelho, 1999, p. 254). Apesar da ação dos diferentes lobbies, grupos de interesses e facções suprapartidárias (como o surgimento do Centrão em fins de 1987), o pesquisador, com base na análise das votações mais importantes e de todo o desenvolvimento dos trabalhos constituintes, entende que o "controle das decisões continuou [...] estritamente partidário e orientado pelo PMDB" (Coelho, 1999, p. 254).

Mas talvez a Constituinte, ao contrário do que entendem Scott Mainwaring e Aníbal Pérez Liñan (1998, p.107), não tenha sido "uma boa oportunidade para um estudo mais detalhado sobre a disciplina partidária numa legislatura do Terceiro Mundo". A Constituinte iniciou-se numa conjuntura muito especial que marcou o retorno do País a uma nova fase de sua vida política. Tratava-se de um momento de adaptação dos grupos de interesses, das correntes políticas e das várias elites a um novo contexto institucional em que o grau de incerteza, para os partidos e para os políticos, havia se elevado em virtude de uma competição mais livre e mais dura pelo voto de um eleitorado profundamente renovado pelo seu fantástico crescimento num curto espaço de tempo. ${ }^{9}$

O novo contexto institucional abriu às várias facções da classe política - agora livres da canga militar e com menos barreiras para a colonização do Estado - estratégias e alianças eleitorais que propiciavam ou estimulavam novas formações partidárias necessárias para a ocupação e repartição de um aparelho estatal imenso que oferecia milhares de postos na administração pública direta ou indireta, nas empresas estatais e nos legislativos federal, estaduais e municipais. A ANC foi um momento especial, não só de reorganização partidária como de renovação das elites políticas brasileiras. Para veteranos e novatos, a ascensão, permanência ou

${ }^{9}$ Na última eleição direta antes do movimento militar de 1964, a de outubro de 1960 para a Presidência da República, o número de eleitores registrado foi de 15,5 milhões e o de votantes, 12,6 milhões. Na primeira eleição direta para a Presidência da República, a de 15 de novembro de 1989 ( $1^{\circ}$ turno), que elegeu Collor, esses números foram, respectivamente, 82 milhões e 72,3 milhões. entrada na classe política em reestruturação (quase $60 \%$ de seus membros na ANC estavam no primeiro mandato) levavam a mudanças de legendas e elevavam os coeficientes de indisciplina em organizações partidárias ainda em formação ou ainda não consolidadas, pouco preparadas para atuar na nova ordem democrática.

A ANC era soberana em suas deliberações. Essa condição sugeria a crença de que os dispositivos legais inseridos na nova Carta teriam o condão de modelar o futuro do País. Se, de fato, da ANC sairia um "Novo Brasil" é algo que se pode duvidar. Mas o que não é de se duvidar é que ela iria fixar algumas das mais importantes regras do jogo político, de acordo com a visão e com os interesses próprios de cada facção que acreditava estar plantando as sementes para sua futura hegemonia. Interesses corporativos, econômicos, setoriais e regionais de toda espécie ficaram mais acesos do que nunca a fim de tentar garantir (e cristalizar ad infinitum) na nova Constituição benefícios coletivos e seletivos materiais assim como disposições políticas que acreditavam lhes ser vantajosos na disputa pelo poder.

Assim, muito mais do que tenderia a acontecer se já existisse um desenho institucional anterior cujos componentes básicos fossem preservados, o caráter fundacional da Constituinte favoreceu acordos e alianças que, embora não totalmente aleatórias diante das diferenciações ideológicas e de classe, aproximavam e separavam os parlamentares nas votações sobre questões específicas que tendiam a passar por cima dos partidos, aumentando assim as taxas de indisciplina partidária. ANC:

Como assinala Stéphane Monclaire, um dos principais estudiosos da

Numerosos constituintes buscaram o apoio ou tentaram formar coteries fundadas no pertencimento a uma mesma região, a uma mesma profissão, a uma mesma religião ou aos mesmos interesses econômicos. Desse modo, na ANC, apareceram e desapareceram ao longo dos debates, impuseram-se e dividiram-se ao sabor das reuniões, uma dezena de associações (no sentido weberiano do termo), tais como o NoNeCo, agrupando 292 constituintes dos Estados do Norte, do Nordeste ou do Centro-Oeste; o Grupo dos Evangélicos, instrumento dos deputados protestantes; o Centro Democrático; o Grupo dos 32; o Centrinho, aliás Grupo da Razão, ou 
ainda Grupo do Consenso, ativado por constituintes, amiúde muito minoritários em seus partidos de origem, ou por vezes marginalizados em um desses grupos; e sobretudo o Centrão [...] [Monclaire, 1991, p. 79]. ${ }^{10}$

Entretanto, mesmo não sendo a ANC o momento mais adequado para aquilatar a fidelidade e a disciplina partidárias, em nossa pesquisa sobre os partidos, a ideologia e a distribuição da composição socio-ocupacional na ANC, pudemos constatar que os partidos efetivos (efetivos, relevantes ou significativos, como se queira) possuíam o que então denominamos "núcleo dominante", ou seja, uma categoria socioprofissional majoritária que formava a espinha dorsal de cada legenda e lhe dava a tonalidade ideológica e a orientação político-programática (Rodrigues, 1987, p. 87).

Claramente, os que se definiam mais à esquerda eram os mais favoráveis ao intervencionismo econômico, à reforma agrária e mais hostis ao capital estrangeiro, enquanto os que se definiam mais à direita tinham posições inversas. Além disso, a proporção de deputados que se autoclassificaram como de direita moderada e de centro aumentava entre o grupo dos empresários enquanto, inversamente, entre os parlamentares de profissões intelectuais, manuais e de nível médio, crescia a proporção dos que se declaravam de esquerda. Havia, pois, não somente certa consistência ideológica a diferenciar os partidos como também correspondência entre a composição social das bancadas e suas preferências políticas e programáticas. $^{11}$

Outros achados contra a tese da "geleia geral" vão na mesma direção. Paradoxalmente, Maria D' Alva Gil Kinzo que endossa a visão geral pessimista do sistema partidário brasileiro, ao analisar a posição dos

\footnotetext{
${ }^{10}$ Monclaire, que estudou detalhadamente o jogo político interno na Constituinte, salienta as consequências do acúmulo de mandatos (constituinte/parlamentar) nos resultados das votações, o peso da intervenção do Executivo - do Presidente Sarney, mais concretamente -, a força dos numerosos lobbies e de outros interesses, abertos ou ocultos, de cuja atuação resultou a Constituição de 1988. Cf. também Monclaire (1992) e especialmente Monclaire 8c. Barros Filho (1988).

${ }^{11}$ Para fins de análise da composição socio-ocupacional da Constituinte, agregamos as diferentes profissões/ocupações em quatro grupos principais: 1) as profissões intelectuais (advogados, engenheiros, médicos, professores etc.); 2) empresários urbanos, rurais ou de atividades mistas; 3) servidores públicos e tecnocratas do Estado da administração pública direta e indireta etc.; e 4) profissões manuais e técnicas de nível médio.
}

partidos na Constituinte em 33 votações importantes, encontrou perfis partidários muito definidos que se aproximavam bastante dos que achamos em nossa pesquisa. A autora conclui que "clivagens ideológicas substanciais se manifestaram entre os partidos" (Kinzo, 1993, p. 77). O apoio à redução da intervenção do Estado decresce, nota Kinzo, à medida que se passa do PFL ao PDS, deste para o PMDB, PSDB, PDT e PT. Os dois partidos considerados mais à esquerda (PT e PDT) são os mais nacionalistas e os mais estatizantes. Mais importante ainda: as posições dos partidos nos Estados seriam notavelmente semelhantes à dos partidos no Congresso (quer dizer, no plano federal). Além disso, comparando as diferenças partidárias entre as regiões, Kinzo considera que as "variações regionais não são marcantes a ponto de anularem os traços gerais que delineiam perfis distintos entre os principais partidos" (Kinzo, 1993, p. 82). No final, os dados da pesquisa de Maria D’Alva Gil Kinzo indicaram consistência ideológica dos partidos em âmbito nacional e coerência com as posições assumidas por eles nos Estados.

Também Rachel Meneguello, em estudo que efetuou posteriormente sobre as relações entre o Executivo federal e os partidos políticos no período entre 1984 e 1997, emite uma opinião mais positiva sobre o sistema partidário brasileiro. Com base em dados de sua pesquisa, Rachel Meneguello, de algum modo, revê sua avaliação pessimista anterior ao concluir que "a lógica subjacente à definição das bases governamentais é uma lógica partidário-parlamentar" e que "a natureza partidária das equipes de governo mostra que os partidos são agentes centrais do funcionamento dos governos no período" (Meneguello, 1998, p. 150). ${ }^{12}$

Outro estudo que sugere mudança de posição é o de Scott Mainwaring, Rachel Meneguello e Timothy Power sobre os partidos conservadores brasileiros. Desse trabalho estão ausentes as avaliações negativas anteriores sobre os partidos brasileiros. Apesar de assinalarem que os deputados conservadores, comparativamente, trocam mais frequentemente de legenda e são mais dependentes do clientelismo "como mecanismo de sustentação das carreiras políticas" (Mainwaring, Meneguello \& Power, 2000, p. 93), os autores observaram uma clara diferenciação programática dos partidos conservadores. $\mathrm{O}$ fato possibilitaria

\footnotetext{
${ }^{12}$ Rachel Meneguello examinou a composição dos ministérios nos governos de Tancredo Neves, José Sarney, Fernando Collor, Itamar Franco e Fernando Henrique Cardoso. 
sua classificação em termos ideológicos, podendo os partidos ser diferenciados "com base em suas posições programáticas", o que permite também "uma localização clara [dos partidos] na escala esquerda-direita. "A imagem, antes prevalecente, de partidos não programáticos, com apenas pequenas diferenças entre si, é enganosa [...]” (Ibidem, p. 42).

Mais significativamente ainda, os autores consideram que as posições dos partidos no Congresso Nacional (1990 e 1997) "na escala esquerdadireita, emergem de forma notavelmente consistente" (Mainwaring, Meneguello 8z. Power, 2000, p. 42).

Outro pesquisador, André Singer, num trabalho polêmico sobre as disposições políticas do eleitorado, vai um pouco mais longe. Segundo o autor, o perfil ideológico dos partidos seria detectado por parte importante do eleitorado. Singer entende que, apesar de cerca de $60 \%$ dos eleitores não saberem a distinção entre direita e esquerda, a identificação ideológica influencia o voto e é particularmente importante para $44 \%$ do eleitorado. Mais ainda: pelo menos uma parcela do eleitorado (mais o de esquerda do que o de direita) seria sensível às "traições" partidárias e capaz de punir trânsfugas (Singer, 1999).

\section{... E reavaliando alguns indicadores}

$\mathrm{Na}$ onda do "movimento revisionista", contribuição importante tem sido o exame de alguns indicadores do grau da consistência dos partidos. Vejamos alguns dos principais.

A lógica ideológica das coligações partidárias — Um aspecto do sistema partidário brasileiro que geralmente tem servido de base para sua avaliação negativa são as coligações partidárias. Permitidas pela legislação, mesmo em eleições proporcionais, elas são frequentes. Muitas vezes unem legendas ideológica e programaticamente discrepantes. Para a opinião pública, as coalizões nas eleições proporcionais seriam mais uma evidência da inconsistência programática dos partidos brasileiros. De fato, para citar apenas dois casos: nas eleições de 1990, o PMDB teve 59\% e o PSDB $62 \%$ de seus parlamentares eleitos em coligações. Nessa eleição, cerca de $80 \%$ dos deputados eleitos o foram por meio de coligações de seus partidos (Novaes, 1994, p. 111).
Contudo, as coligações não são tão aleatórias como habitualmente se tende a crer, o que diminui seu significado como indicador da inconsistência programática dos partidos. Na grande maioria das vezes, as coligações se fazem entre partidos com alguma afinidade ideológica: partidos de direita entre si, partidos de direita com partidos de centrodireita, partidos de esquerda entre si e partidos de esquerda com partidos de centro-esquerda. Embora haja coligações inconsistentes, a maioria obedece à lógica da afinidade ideológica (Novaes, 1994, p. 113).

Posteriormente, e na mesma direção, Rogério Schmitt, no seu estudo sobre coligações partidárias nas eleições para a CD (período de 1986 a 1994), mostrou que as coligações consistentes (que se realizam no interior do mesmo bloco ideológico) corresponderam a $65,9 \%$ do total e as inconsistentes (esquerda com a direita) chegaram somente a $15,5 \%$ do total (Schmitt, 1998, p. 107). A conclusão do autor é de que, aceitando-se as coligações mais ou menos consistentes (partidos do centro com partidos de direita e esquerda), "quase nove em cada dez alianças se deram entre partidos situados em posições idênticas ou contíguas do espectro ideológico" (idem, ibidem).

As migrações partidárias - Outro ponto de crítica aos partidos e políticos brasileiros, como vimos, diz respeito às mudanças de legendas, consideradas excessivas e reveladoras de falta de programas e de ausência de compromisso ideológico dos Míticos e também dos partidos que acolhem calorosamente os trânsfugas, Mas aceitando o pressuposto, quase de senso comum, de que o rompimento da imposição autoritária do bipartidarismo, o retorno ao regime democrático e ao jogo do mercado eleitoral dificilmente poderiam deixar de provocar uma reacomodação partidária da classe política, os indicadores de trocas de legendas devem ser interpretados a partir de uma sequencia temporal, considerando especialmente os mesmos contextos institucionais. No caso, a evolução do fenômeno deveria ser medida dentro da situação de continuidade democrática, num período mais ou menos longo, incluindo pelo menos três eleições consecutivas. ${ }^{13}$

${ }^{13}$ É difícil apontar o número de eleições a partir do qual a continuidade dos fenômenos, no interior de um nova ordem política, provoca um conjunto de pequenas alterações que indicam uma tendência que se desenha sem que haja alteração institucional, quero dizer, 
Nesse sentido, são importantes os dados da pesquisa de Jairo Nicolau que abrangem uma série mais longa de migração partidária na CD (1980 a 1994) e indicam a redução da taxa de troca de legenda. No período, segundo o autor, o fato relevante a destacar foi "a tendência à diminuição constante do índice [de migrações], a partir de 1985; ou seja, o impacto das trocas de legenda sobre a composição das bancadas é cada vez menor" (Nicolau, 1996, p. 69). De modo mais preciso, decaiu de 16,7 trocas para 5,4, em $1994 .{ }^{14}$

Mas, mesmo que aceitemos que as taxas de migração partidária no Brasil sejam muito elevadas, há outras indicações que atenuam seu papel como elemento comprobatório da inconsistência programática dos nossos partidos. Ocorre que as trocas de legenda não são inteiramente aleatórias e são influenciadas por variáveis de tipo ideológico-programático que diferem de partido para partido.

Por exemplo: Rogério Schmitt, no seu estudo sobre as mudanças de legenda na CD da 49 ${ }^{\mathrm{a}}$ Legislatura (1991 - 1995), mostrou que "a migração partidária não é um fenômeno majoritário entre a classe política, e mesmo entre os que a praticam, é predominantemente realizada dentro dos mesmos blocos ideológicos" (Schmitt, 1999, p. 131).

Nesse aspecto, os resultados da pesquisa sobre essa legislatura vão na mesma direção dos de Carlos Alberto Novaes relativos à Legislatura anterior, eleita em 1990. Segundo Novaes, os alinhamentos majoritários na CD correspondem aos cortes clássicos entre esquerda e direita. Repetem "o desenho ideológico das coligações eleitorais ideológicas" ainda que alinhamentos ideológicos não signifiquem organicidade partidária "ou

obedecendo às mesmas regras do jogo. Indagando-se por quantas legislaturas o tipo de estruturação partidária que classifica de "predominante" deve manter essa condição, Sartori sugere que "três maiorias absolutas consecutivas podem ser indicação suficiente, desde que o eleitorado pareça estabilizado" (Sartori, 1982, p. 228, grifos nossos). Talvez o número de três renovações de legislaturas pudesse ser tomado também como um período mínimo capaz de possibilitar uma melhor avaliação dos fenômenos de volatilidade eleitoral e partidária.

14 Muitos fatores influenciam as trocas de legendas, tais como mudanças institucionais, criação de novos partidos, transformações socioeconômicas, novas leis eleitorais etc. Para o período estudado, Jairo Nicolau apresenta três motivos principais para explicar a troca de legendas entre 1985 e 1994: conflitos de natureza ideológico-pragmática no partido de origem; conflito de natureza pessoal no interior do partido de origem e maximização das oportunidades eleitorais (Nicolau, 1996, p. 70). mesmo fidelidade partidária e prática legislativa colegiada". "As estruturas partidárias são frágeis, mas as afinidades ideológicas conformam campos estáveis" (Novaes, 1994, pp. 114 e 113).

Pode-se também questionar a dimensão dos efeitos negativos das trocas de legendas sobre a organização e o funcionamento dos partidos, especialmente quando medida pela disciplina das bancadas no Congresso. Carlos Ranulfo de Melo, em sua pesquisa sobre as migrações partidárias, mostrou que os partidos podem mostrar-se disciplinados em plenário e, ao mesmo tempo, ter altas taxas de migração. De acordo com Melo, a explicação residiria na estrutura de punições e recompensas existentes no Legislativo. A troca de partidos seria uma forma de comportamento racional buscada pelos parlamentares para aumentar suas oportunidades de êxito na carreira política. Melo enfatiza a distinção entre coesão partidária e disciplina no parlamento. Os partidos poderiam ser disciplinados em plenário, mas fracamente coesos, sendo a baixa coesão indicada pela elevada rotatividade dos deputados entre as legendas (Melo, 1999 e 2000). Por isso, embora admitindo a fraca disciplina partidária em plenário, o pesquisador entende que essa variável não poderia ser transformada num "atributo por excelência para um diagnóstico sobre os partidos brasileiros" (Melo, 2000, p. 223).

A organização partidária - A visão de senso comum sobre os partidos brasileiros é de que, excetuando-se os partidos de esquerda, os demais não passariam de legendas despidas de qualquer estrutura organizatória. Contudo, há um achado intrigante que indica a necessidade de verificar com mais rigor quão desestruturados são os partidos brasileiros. O cientista político Barry Ames, ao estudar organização partidária local nas eleições presidenciais de 1989, afirma que "apesar da curta história dos partidos brasileiros, de suas frágeis estruturas organizatórias e da falta de coesão ideológica (pelo menos quando comparadas com partidos europeus), os eleitores manifestaram certos apegos habituais a um determinado partido ou a uma orientação ideológica geral" (Ames, 1994, p. 16).

A partir da análise da distribuição dos votos dos candidatos à Presidência, o pesquisador norte-americano conclui que seu estudo mostra a importância da organização partidária local sobre os resultados eleitorais: 
A análise sugere que o apoio e a mobilização dos partidos foram efetivamente valiosos, tendo exercido um grande impacto sobre o destino das principais candidaturas [...] Embora Collor de Mello pudesse ter saído vitorioso, o "fenômeno Collor" foi, com toda certeza, uma exceção. Em uma eleição normal, a organização local teria sido decisiva, ou seja, a impressão de que os partidos estavam mortos não passa de um exagero [idem, p.9]. ${ }^{15}$

A disciplina partidária - No sentido de favorecer uma reavaliação dos partidos brasileiros, os trabalhos de Argelina Cheibub Figueiredo e de Fernando Limongi provavelmente foram os que tiveram maior impacto ao oferecer novos dados para a reflexão sobre a coesão, a disciplina e a coerência ideológica dos partidos no Legislativo Federal. Os autores examinaram como os membros das várias bancadas votaram num período posterior à Constituinte (1989-1998). A partir do estudo de várias votações importantes, Cheibub e Limongi concluem — de modo surpreendente para as concepções tradicionais sobre os partidos brasileiros - que os partidos, na CD (períodos de 1989-1993 e 1989-1998), mostraram forte coesão e um posicionamento programático consistente (Figueiredo \& Limongi, 1995 e 1999).

Os partidos, de acordo com os autores, podem ser dispostos num contínuo ideológico em que as "coalizões contíguas", notadas também por outros pesquisadores, são a regra. Comparando o encaminhamento dos líderes com os votos das bancadas, Fernando Limongi e Argelina Figueiredo verificaram que a coesão e a disciplina dos partidos no período haviam sido elevadas. Três blocos ideológicos foram caracterizados pelos autores: a direita (PDS, PFL e PTB), o centro (PMDB e PSDB) e a esquerda (PDT e PT). Em geral, os partidos do mesmo bloco ideológico votaram de maneira similar.

É certo que havia diferenças no tocante à disciplina interna das bancadas. Os deputados dos partidos de esquerda eram os mais obedientes às decisões da maioria da bancada, mais propensos a acompanhar as decisões das suas lideranças. No caso do PT, observam Limongi e

\footnotetext{
${ }^{15}$ Obviamente, Ames sabe que os candidatos que contavam com as mais fortes organizações partidárias não conseguiram passar para o segundo turno. Entende, porém, que "seus respectivos desempenhos teriam sido ainda mais fracos sem o apoio das mesmas" (Ames, 1994, p. 30).
}

Figueiredo, a unanimidade de voto tendia a ser a regra. Mas também os partidos de direita mostraram coesão, especialmente quando os três partidos que formavam o grupo votavam da mesma maneira. Em 109 desses casos, entre 1989 e 1993, a coesão média do PDS chegou a 87,9\%, a do PFL, a $89,3 \%$ e a do PTB, a 78,1\%. No entanto, quando a direita se dividia, a coesão interna dos partidos tendia também a declinar. No total, $89 \%$ do plenário votou de modo disciplinado. "Os partidos — afirmam os autores - apresentaram considerável coesão média no período como um todo [...] O quadro que emerge da análise revela um padrão de coalizões partidárias que é coerente com a disposição dos partidos num continuum ideológico. Podemos falar tranquilamente em partidos de direita, de centro e de esquerda" (Figueiredo \& Limongi, 1999, p. 75).

Em outras pesquisas sobre a disciplina partidária na $\mathrm{CD}$, Argelina Cheibub Figueiredo e Fernando Limongi calcularam em 0,894 a probabilidade de que um parlamentar qualquer votasse com a liderança de seu partido, "taxa suficiente - no dizer dos pesquisadores - para predizer com acerto, 93,7\% das votações nominais". Mas as probabilidades do voto disciplinado variam com os partidos: para o PT e o PFL, os mais disciplinados, as taxas seriam de 0,973 e 0,901; para o PMDB e o PTB, os mais indisciplinados, seriam de 0,857 (Limongi \& Figueiredo, 1998, pp. 83 e 90$){ }^{16}$

Índices elevados de disciplina no Legislativo foram também encontrados por Maria Herminia Tavares de Almeida e Maurício Moya em pesquisa que investigava a opinião dos congressistas sobre as áreas em que entendiam ser necessária a atuação empresarial em contraposição à do

\footnotetext{
${ }^{16}$ É possível ver uma relação entre as variações nos índices de disciplina partidária dos vários partidos (avaliados pelas votações no plenário da $C D$ ) e o grau de homogeneidade da composição sócio-ocupacional das bancadas. PFL c PPB, numa ponta, e PT, na outra, são socialmente muito diferentes quanto às suas bancadas: entre os dois primeiros, os empresários e deputados de maior patrimônio são majoritários, enquanto no PT predominam os professores, profissionais liberais e sindicalistas de baixo patrimônio. Mas são, comparativamente, menos divididos internamente do que o PMDB e o PSDB. A hipótese surgida no decorrer de nossa pesquisa (mas que não será testada) é de que, ceteris paribus, os partidos internamente mais coesos socialmente (no caso os partidos de direita e de esquerda) são mais disciplinados do que os de centro, menos coesos do ponto de vista de sua composição social. A identificação ideológica, que resulta em maior disciplina partidária, viria da menor diversidade social das bancadas.
} 
Estado. Novamente, a distribuição por partido mostrou uma significativa diferença entre congressistas dos vários partidos ao longo do clássico gradiente direita-centro-esquerda: os parlamentares dos partidos mais à esquerda inclinando-se por mais intervencionismo e, os mais à direita, por menos (Almeida \& Moya, 1997), tendência encontrada há alguns anos também por Rodrigues (1987) e Kinzo (1993).

Mais recentemente, Jairo Nicolau tratou também do tema da disciplina partidária na $50^{\mathrm{a}}$ Legislatura da Câmara dos Deputados $\left(1^{\circ} \mathrm{de}\right.$ fevereiro de 1995 a 31 de janeiro de 1999) durante o primeiro governo de Fernando Henrique Cardoso. Medindo o fenômeno pela obediência dos parlamentares à indicação dos líderes das bancadas quando das votações em plenário, o autor encontrou índices altos de disciplina partidária. Tal como Fernando Limongi e Argelina Figueiredo haviam observado na sua pesquisa, os índices variaram segundo os partidos e as matérias em votação, mas, na maioria dos casos, foram elevados. Jairo Nicolau distinguiu três blocos de partidos definidos segundo os coeficientes de disciplina: 1) partidos com valores próximos de $100 \%$ : PC do B e PT; 2) partidos cujas taxas variaram em torno de 90\%: PFL, PDT, PSDB, PSB e PTB; e 3) partidos com taxas mais baixas, em torno de $80 \%$ : PPR/PPB, PMDB e PL (Nicolau, 2000, p.726). Esses resultados - se não são comprovantes de fidelidade partidária, de coerência ideológico-programática e de coesão, qualidades que se supõe existir nos países desenvolvidos - sugerem um mapa partidário menos desestruturado e instável, com um menor potencial de risco para a consolidação da democracia no País.

Os resultados das investigações dos cientistas políticos citados há pouco permitem indagar quão "subdesenvolvido" seria o sistema partidário brasileiro. Uma pesquisa que possibilita uma avaliação comparativa dos partidos brasileiros com os de outros países encontra-se na obra de Paulo Sérgio Feres. O autor procurou verificar empiricamente e de modo mais amplo o grau de instabilidade do sistema político brasileiro por meio da mensuração de seus índices de volatilidade eleitoral e ideológica. A escolha do índice de volatilidade, utilizado para comparações entre países, permite localizar o País no mapa-múndi partidário, possibilitando juízos mais relativizados sobre nossos partidos.

Os resultados dos cálculos de Peres indicam que, de facto, a taxa de volatilidade eleitoral média brasileira é elevada comparativamente às da
Europa, "embora não tão elevada a ponto de não podermos falar em qualquer tipo de estruturação estável [...]" (Peres, 2000, p. 140) ${ }^{17} \mathrm{Em}$ comparação com a América Latina, estaria num nível intermediário. Mais ainda: Peres entende que o sistema partidário brasileiro apresentaria uma estabilidade média suficientemente elevada para "invalidar a afirmação de que seja totalmente inconsistente" (idem, p. 142).

Mais importante ainda para a avaliação do caso brasileiro são os resultados da análise diacrônica. Elas indicam que o nosso sistema partidário estaria, cada vez mais, estruturando as preferências eleitorais (idem, p. 151).

Os índices de volatilidade ideológica, que medem as variações das preferências do eleitorado entre blocos de partidos de direita, centro e esquerda constituem outro parâmetro importante de comparação entre o Brasil e vários países da Europa. Nesse aspecto, embora a volatilidade brasileira seja muito mais elevada do que as dos sistemas europeus e de sua média, os achados de Peres indicam decréscimo desse índice nesse curto período de vivência democrática, sendo a volatilidade ideológica brasileira, entre 1994 e 1998, menor do que a de qualquer país europeu (Peres, 2000, p. 159). O resultado geral da pesquisa de Paulo Sérgio Peres é de que a instabilidade sistêmica do sistema político brasileiro mostra uma dinâmica de declínio.

Conjugando os dados sobre a volatilidade eleitoral com os de outras pesquisas - influência das organizações partidárias locais nos resultados eleitorais, trocas de legenda, tipos de coligações, disciplina das bancadas nas votações na $\mathrm{CD}$, perfis ideológicos no Congresso e nas assembleias

17 Peres utilizou a fórmula desenvolvida por Mogens Pcdersen (1980, 1990), também utilizada, com alguma variação, por Stefano Bartolini e Peter Mair (Bartolini \& Mair, 1990). A fórmula, bastante simples, serviu para introduzir um indicador quantitativo nas discussões sobre as hipóteses do desalinhamento partidário na Europa. Destinou- se, portanto, a testar a hipótese de desestruturação de sistemas estáveis. No caso brasileiro, nota Paulo Sérgio Peres, com razão, que a intenção foi medir possível estabilização de um sistema em formação. As fórmulas que permitem a construção de índices de volatilidade partidária e ideológica são conhecidas pelos cientistas políticos que trabalham sobre sistemas partidários e eleitorais Para os leitores leigos, o conhecimento da fórmula não é necessário para acompanhar a argumentação do autor, razão pela qual abstemo-nos de reproduzi-la. O leitor interessado encontrará em Jairo Nicolau (1997) e em Peres (2000), entre muitos outros autores, uma descrição da fórmula. 
legislativas etc. —, parece ser mais correto trabalhar com a hipótese de que o sistema partidário brasileiro está em processo de estruturação e não com a de que se trata de um sistema em desestruturação ou intrinsecamente incapaz de organização.

Certamente, o ritmo de avanço partidário pode ser objeto de controvérsias e pode ser entendido como demasiadamente lento. Mas a direção das mudanças parece-nos indicar o fortalecimento dos partidos, tanto no que se refere à configuração de seu perfil ideológico, capacidade de expressar demandas da sociedade, como no que se refere à sua capacidade de dar sustentação partidária aos governos.

É possível imaginar, nesse ponto, que os diagnósticos mais críticos sobre os partidos brasileiros - e mesmo alarmistas quanto ao futuro da democracia entre nós - decorressem, muitas vezes, do fato de analisar um sistema partidário ainda em formação depois dos longos anos de governos militares, de vigência de eleições apenas semicompetitivas típicas dos regimes autoritários (Nohlen, 1994). ${ }^{18}$ Não havia ainda decorrido um período mais longo de vivência democrática que fizesse com que a concorrência entre partidos favorecesse a eliminação do mercado eleitoral das legendas inexpressivas, sem maiores compromissos com correntes ideológicas, grupos de interesses e outras linhas de clivagem da sociedade. ${ }^{19}$ Por isso, é possível que as opiniões então emitidas pela corrente mais crítica fossem hoje diferentes.

\section{Conclusão}

Os trechos dos trabalhos dos autores que citamos não transmitem a complexidade das suas análises e argumentos. Muita coisa importante de seus trabalhos foi deixada de lado. Nossa justificativa é de que nos concentramos nos pontos em que seus achados indicavam a necessidade de uma reavaliação dos juízos sobre os partidos brasileiros. Não houve a pretensão de um arrolamento amplo do que tem sido escrito nesses últimos

18 Dieter Nohlen associa eleições competitivas a sistemas democráticos; eleições semicompetitivas, a sistemas autoritários, e eleições não competitivas, a sistemas totalitários (Nohlen, 1994).

${ }^{19}$ Sobre a formação dos partidos no período de 1985-1994, cf. Jairo Nicolau (Nicolau, 1996), especialmente capítulo I , "Partidos e Legislação Partidária no Brasil (1985-1994)". anos e muito menos de tomar partido (sem trocadilho) sobre a correção dos levantamentos, da metodologia, da interpretação dos dados coletados e das conclusões derivadas de levantamentos bem mais complexos e sofisticados do que poderiam sugerir as passagens que citamos. Interessou-nos apenas mostrar que algumas das opiniões (negativas) mais difundidas sobre o sistema partidário do País deveriam ser matizadas.

Desse ponto de vista, acreditamos que os aspectos que destacamos cumpriram, pelo menos em parte, esse papel. Mas há um ponto que merece ser levantado: a maioria dos trabalhos referidos, tanto os que insistem mais duramente sobre a falta de consistência dos partidos quanto os que deles oferecem uma visão mais benigna, estão no campo do que se poderia denominar de abordagens de tipo institucional. As fontes sociais de recrutamento das lideranças dos partidos têm sido pouco estudadas.

O presente estudo pretende acrescentar alguns elementos para a avaliação dos partidos brasileiros de uma perspectiva que se aproxima mais de uma sociologia política. Basicamente, para repetir o que foi anunciado inicialmente, o fulcro do trabalho é a composição socio-ocupacional das bancadas na legislatura eleita em 1998. Entendemos que o levantamento da composição ocupacional das bancadas indica diferenças significativas entre os partidos, singularizando-os e fazendo com que suas cúpulas representem interesses socioeconômicos diferenciados, relativamente compatíveis com as posições políticas assumidas pelos seus representantes na CD. 


\section{A COMPOSIÇÃO SOCIAL DA 51 a LEGISLATURA}

Este capítulo expõe, no início, a classificação ideológica dos seis partidos incluídos na pesquisa. Em seguida, analisa os resultados do levantamento sobre a composição social da Câmara dos Deputados, pela qual se vê que o recrutamento para a classe política brasileira vem basicamente de quatro segmentos ocupacionais: o setor empresarial, as profissões liberais, o funcionalismo público e o magistério.

\section{As classificações ideológicas}

A definição do PPB e o do PFL como partidos de direita, do PMDB e do PSDB, como partidos de centro e do PDT e do PT, como partidos de esquerda é a que tem sido adotada mais recentemente por quase todos os pesquisadores brasileiros e brasilianistas. Por exemplo, (em ordem cronológica crescente das datas de publicações): Bolívar Lamounier (Lamounier, 1989); Luís Fernandes (Fernandes, 1995); Fernando Limongi e Argelina Figueiredo (Limongi 8.L Figueiredo, 1995); Olavo Brasil de Lima Jr. (1997); David Samuels (Samuels, 1997); Rachel Meneguello (Meneguello, 1998); Rogério Schmitt (Schmitt, 1998 e 1999); André Singer (Singer, 1999); Carlos Ranulfo Melo (Melo, 1999); Amorim Neto (2000); Scott Mainwaring, Rachel Meneguello e Timothy Power (Mainwaring, Meneguello \& Power, 2000); Barry Ames (Ames, 2001) e André Marenco dos Santos (Santos, 2001 e 2000).

Há, no entanto, algumas divergências com relação a essa caracterização. Para Maria D'Alva Gil Kinzo, o PT seria o único "realmente de esquerda", observação que parece correta à luz não apenas das posições político-programáticas como da composição social da bancada petista. Para a pesquisadora, PDT e PSDB estariam na posição de centro-esquerda; o PMDB e o PTB ocupariam o centro do espectro; a posição de centro-direita caberia ao PL, ao PDC, ao PFL e ao PDS (Kinzo, 1993, p.79). ${ }^{1}$

${ }^{1}$ Maria D’Alva Kinzo apoia-se numa escala de distância ideológica a partir de avaliações feitas pelos próprios deputados dos legislativos estaduais em pesquisa efetuada pela autora em 1989. Trata-se, pois, de uma classificação com "base empírica", que não vem do juízo da pesquisadora, razão pela qual é especialmente relevante.
Já Carlos Alberto Novaes classificou o PDT e o PSDB como de centro-esquerda e o PMDB, como de centro-direita (Novaes, 1994, p. 111). Tal como Kinzo e Novaes, o DIAP definiu o PDT como sendo de centroesquerda. ${ }^{2}$

Outra classificação que foge da habitual é a de Olavo Brasil de Lima Jr. que, em 1993, colocou o PMDB entre os partidos de direita, junto com o PDS, o PFL e o PTB. O PSDB foi incluído entre os partidos de esquerda, ao lado do PCB e do PDT (Lima Jr., 1993, p. 61). ${ }^{3}$

A discussão sobre a "verdadeira" e "correta" caracterização programática dos seis partidos é um assunto no qual não queremos entrar. Nossa hipótese era de que haveria diferenças significativas na composição social das respectivas bancadas - verificáveis empiricamente pelos segmentos socioprofissionais nelas presentes - e de que a essas diferenças corresponderiam posições políticas programáticas e ideológicas, convencionalmente tidas como de direita, de centro e de esquerda. A partir de estudos anteriores, esperávamos encontrar, como de fato aconteceu, proporção significativamente diferente de grupos ocupacionais no interior das bancadas partidárias. A suposição, quase intuitiva e lógica, era de que, ceteris paribus, os parlamentares, segundo suas origens e seus status socioeconômicos, tenderiam a candidatar-se por partidos que mais se aproximassem de suas convicções ideológicas e que, idealmente, mais atendessem aos seus interesses pessoais. Está implícita a suposição de que posições políticas e ideológicas têm alguma relação com o modo como as

${ }^{2}$ A classificação do PDT como um partido de centro-esquerda talvez seja a mais apropriada à luz, inclusive, das diferenças na sua composição social que encontramos na pesquisa e não apenas de sua orientação política (nacionalista e estatizante), que levou esse partido, no Congresso, a votar de modo muito semelhante ao PT e ao PC do B, entendidos indiscutivelmente como de esquerda. Mas, aqui, preferimos evitar caracterizações mais específicas, mesmo porque as fronteiras dos campos ideológicos não são assim tão nítidas. Além disso, o número de parlamentares do PDT nos pareceu pequeno demais para possibilitar a criação de uma quarta categoria, a de centro-esquerda. Uma vez que, como assinalamos, esse partido vinha, nos últimos tempos, marchando ao lado do PT e dos partidos habitualmente considerados como de esquerda, o PDT foi incluído, nas análises dos blocos ideológicos, no da esquerda, junto com o PT.

Citamos alguns trabalhos mais recentes num rápido levantamento que provavelmente deixou de lado outros autores importantes. Se assim for, apresentamos antecipadamente nossas desculpas. 
pessoas obtêm sua subsistência, seu prestígio, sua legitimidade e seu poder, quero dizer, como se localizam na sociedade.

Não se esperava que os partidos possuíssem bancadas internamente homogêneas e radicalmente diferenciadas umas das outras. De fato, como dados de outros estudos e levantamentos já haviam indicado, o recrutamento parlamentar de cada partido efetua-se em meios sociais e ocupacionais variados, mas o fato não exclui sobrerrepresentações de determinados grupos ocupacionais nas suas bancadas (Fleischer, 1981; Rodrigues, 1987; Braga, 1998; Marques \& Fleischer, 1999; Santos, 2000; Istoé/Senhor/Editora Três, 1991; Folha de S. Paulo, 1998 e 1994). A expectativa, assim, era de que seriam encontradas correlações significativas entre a composição das bancadas (singularizadas pelo peso de certos segmentos profissionais no seu interior) e suas orientações políticas, como nossa pesquisa sobre a Constituinte já havia mostrado. ${ }^{5}$

Desse prisma, a expectativa seria de que os partidos considerados de direita tivessem entre seus deputados uma maior proporção de empresários e pessoas de alta renda enquanto, nos partidos considerados de esquerda, a expectativa seria de uma maior proporção de parlamentares originários das classes médias e das classes trabalhadoras e populares. Já os partidos classificados como de centro teriam proporcionalmente menos empresários e trabalhadores e mais parlamentares originários de estratos sociais

\footnotetext{
${ }^{4}$ Assim formulada, a tese fica excessivamente marxista. Mas não parece inteiramente equivocada se não for tomada de modo exclusivo. No caso específico, a afinidade ideológica e a identificação social não são as únicas variáveis a serem levadas em conta nas escolhas individuais das legendas. Uma variável importante a guiar as opções dos que pretendem entrar para a classe política é o cálculo que cada candidato faz de suas chances de êxito eleitoral ao escolher esse ou aquele partido. Apesar disso, estamos supondo que as preferências se fazem dentro de um leque ideológico; que empresários geralmente não concorrem por partidos de esquerda, os quais, em contrapartida, tendem a ser preferidos por operários, professores e intelectuais.

5 Neste livro, como dissemos inicialmente, não foi possível incorporar o exame dos programas dos partidos. Digamos apenas, com ululante simplismo, que as votações no Congresso e as posições adotadas na política nacional indicam que os partidos tidos como de "esquerda" tenderam sistematicamente a favorecer o intervencionismo estatal, as posições nacionalistas e as medidas tidas como redistributivas; os partidos tidos como de "direita" favoreceram o mercado, a abertura da economia e a redução do intervencionismo governamental, o controle da inflação. Em que medida as respectivas posições atenderam aos interesses do "povo" ou da "Nação" não interessa aqui.

intermediários. Sua orientação política, diante das demandas desses dois grandes segmentos sociais e atores políticos, seria mais matizada, orientada para a conciliação. Mais concretamente: os partidos de direita tenderiam a recrutar seus membros principalmente (ainda que não de modo exclusivo) entre proprietários, homens de negócio, executivos, administradores de empresas e altos funcionários da administração pública; os de esquerda tenderiam a recrutar, em maior proporção, assalariados de classe média, membros das profissões intelectuais de renda mais baixa, professores do setor público, pequenos funcionários e ex-dirigentes sindicais; e os partidos de centro teriam uma distribuição profissional e ocupacional mais heterogênea, profissional e socialmente, com maior proporção de professores, profissionais liberais, membros das profissões intelectuais modernas ao lado de empresários, de executivos e diretores de empresas, de proprietários urbanos e rurais, mas sem a existência de parcela significativa de representantes vindos das classes médias baixas e populares.

\section{Fontes de recrutamento partidário}

As atividades empresariais, as profissões liberais, $o$ alto funcionalismo e o magistério constituem, nessa ordem, os principais segmentos ocupacionais e profissionais de onde veio a quase totalidade dos parlamentares da $51^{\mathrm{a}}$ Legislatura Federal. Os deputados que foram (ou ainda são) empresários do setor urbano e os que foram profissionais liberais compõem as profissões/ocupações mais numerosas. Juntas, as duas chegam a 56\% da CD. A proporção de ex-professores é também elevada em todos os partidos, especialmente no PT. Da administração pública, por sua vez, vieram $18 \%$ do total de deputados.

A categoria "empresário" abrangeu não apenas os proprietários mas também os executivos, diretores de empresas, gerentes e administradores de empresas urbanas, rurais e mistas. A dimensão do empreendimento e o ramo da atividade não foram levados em conta, mas convém informar que, do total de parlamentares incluídos na categoria, 25\% eram pequenos empresários; $40 \%$, médios e 35\%, grandes (Silva, 2002). ${ }^{6}$

${ }^{6} \mathrm{O}$ autor utilizou dados dessa mesma pesquisa para aprofundar o estudo do grupo de parlamentares que foram (ou são) empresários. João Carlos da Silva classificou como pequenos empresários os deputados com patrimônio inferior a 500 mil reais; como médios 
O segundo segmento profissional a servir de fonte de recrutamento político são as profissões liberais tradicionais. Os advogados (ou os bacharéis em Direito) compõem o principal grupo (27\% do total de deputados). Em segundo lugar vêm os diplomados em Medicina (14\%), seguidos pelos formados em Engenharia (13\%). No entanto, se a contagem for feita considerando o exercício efetivo da profissão (última ocupação antes de ser eleito para algum posto político) e não o diploma, a proporção de advogados cai para $10 \%$, a de engenheiros para $6 \%$ e os médicos passam para o primeiro lugar, com $12 \%$ do grupo. ${ }^{7}$ Os dentistas, farmacêuticos e veterinários constituem um grupo muito reduzido, de menos de $1 \%$ do total da CD.

O terceiro setor ocupacional na ordem do fornecimento de membros para a classe política é a administração pública, ou mais exatamente, as altas instâncias da burocracia dos governos estaduais (9\%) e do governo federal $(5 \%)$. Do baixo e médio funcionalismo vieram somente $2 \%$ dos parlamentares.

O magistério é o quarto setor na ordem de importância das profissões que qualificam para a vida a política. Contando todos os níveis da atividade docente, $16 \%$ dos deputados foram professores (81 casos). Desse total, ao menos $71 \%$ vieram do magistério superior: $41 \%$ do ensino público e $30 \%$ do privado ${ }^{8}$.

Aqueles que denominamos "comunicadores" constituem um grupo relativamente grande de parlamentares se considerarmos o reduzido número de pessoas localizadas nesse segmento ocupacional no mercado de trabalho. Os "comunicadores" são principalmente jornalistas (quinze casos) e radialistas/locutores (catorze casos), os quais, juntos com quatro apresentadores de tevê, formam $6 \%$ da CD. Mas, como sabemos, os

empresários, deputados com patrimônio entre 500 mil e dois milhões de reais; e como grandes empresários, os deputados que tinham patrimônio acima de dois milhões (Silva, 2002, p. 54).

${ }^{7}$ Trata-se de um ponto que não será desenvolvido aqui, mas o exercício da profissão de médico constitui um trampolim importante para a entrada na classe política. Aliás, foram médicos alguns dos principais políticos brasileiros, como Adhemar de Barros, governador do Estado de São Paulo, e Juscelino Kubitschek, governador de Minas e, depois, presidente da República.

${ }^{8}$ Dissemos "ao menos" porque há catorze casos de atividades docentes não identificadas. locutores e apresentadores da rádio e da televisão dispõem de um instrumento importante de "popularização" da candidatura junto às camadas de mais baixa renda, o que tende a baratear suas campanhas e facilitar o êxito eleitoral. Já os jornalistas tendem a ser mais "populares" numa fatia menor do eleitorado, possivelmente de níveis mais elevados de escolaridade. Mas trata-se de uma das profissões que, em toda parte e em épocas diferentes, tem contribuído bastante para a composição dos parlamentos ocidentais.

No grupo das "profissões religiosas" (dezoito casos), há ampla predominância de pastores: dezesseis contra somente dois padres. O fato é indicativo de uma disposição das igrejas protestantes e das seitas de crentes de investir diretamente na representação política nacional bem maior do que os padres da Igreja católica, dos quais uma parte dá mais importância às formas de atuação e de pressão política extraparlamentares.

Os empregados não manuais em serviços (catorze casos) são representados majoritariamente por bancários e técnicos: cinco e quatro deputados, respectivamente. O grupo dos trabalhadores industriais é formado quase exclusivamente pelos metalúrgicos. Juntos com um gráfico, compõem a "bancada operária" na CD $(1,4 \%)$.

Por fim, catalogamos como "políticos profissionais" os parlamentares que, stricto sensu, nunca chegaram a exercer uma atividade profissional e que começaram as atividades políticas muito cedo, antes mesmo de terminarem os estudos superiores.

Os parágrafos anteriores sobre as profissões/ocupações e sobre a coleta de dados condensam e às vezes repetem informações mais detalhadas que se encontram no capítulo 10, "Procedimento Metodológico". O leitor interessado em mais explicações sobre a operacionalização da pesquisa pode buscá-las no referido capítulo. Mas, a rigor, a leitura do capítulo 10 é dispensável para a compreensão do conteúdo da análise e pode ser deixada de lado por ora.

No exame do quadro a seguir, deve-se ter em conta que as porcentagens referem-se ao número de profissões/ocupações e não ao de parlamentares, os quais podem ter exercido, concomitantemente, como de fato exerceram, mais de uma atividade ocupacional. Mas, quando no texto está indicada a porcentagem de uma dada profissão ou ocupação, essa 
mesma porcentagem indica também a proporção de parlamentares que exerciam essa profissão quando entraram para a política, o que não implica que não pudessem ter outra, ou outras, ao mesmo tempo.

Quadro 2

Distribuição das profissões/ocupaç̃es desagregadas na Câmara de Deputados (\%)

\begin{tabular}{|l|c|}
\hline Categorias Ocupacionais & 28,5 \\
\hline 1. Empresários urbanos & 10,1 \\
\hline 3. Empresários rurais & 4,9 \\
\hline 4. Empresários "mistos" (urbanos e rurais) & 27,1 \\
\hline 5. Profissionais liberais tradicionais & 4,5 \\
\hline 6. Profissões intelectuais & 6,4 \\
\hline 7. Magistério público superior & 9,4 \\
\hline 8. Outros professores & 4,9 \\
\hline 9. Altos funcionários do governo federal & 9,0 \\
\hline 10. Altos funcionários de governos estaduais & 1,8 \\
\hline 11. Altos funcionários de governos e câmaras municipais & 1,8 \\
\hline 12. Baixo e médio funcionalismo público & 2,5 \\
\hline 13. Diretores de bancos estatais & 6,4 \\
\hline 14. "Comunicadores" & 3,5 \\
\hline 15. Pastores e padres & 2,7 \\
\hline 16. Empregados não manuais em serviços & 1,4 \\
\hline 17. Trabalhadores industriais qualificados & 0,6 \\
\hline 18. Lavradores e trabalhadores rurais & 0,8 \\
\hline 19. "Políticos” & 0,4 \\
\hline 19. Sem informação & 84,6 \\
\hline
\end{tabular}

Obs.: A soma das porcentagens é superior a $100 \%$ porque 84 deputados têm mais de uma ocupação/profissão. No corpo do texto, as porcentagens, que nas tabelas aparecem com uma decimal, estarão sempre arredondadas.

\section{OCUPAÇÃO, PROFISSÃO E IDEOLOGIA}

O capítulo expõe, no início, a relação entre os grupos socio-ocupacionais que formam as bancadas e os blocos ideológicos (direita, centro e esquerda). Em seguida, a mesma problemática é focalizada do ângulo de cada um dos partidos individualmente. A conclusão final é de que há uma vinculação consistente entre as posições políticas e programáticas, por um lado, e a composição social das bancadas partidárias, por outro.

\section{Os perfis dos blocos}

No capítulo anterior, mostramos a distribuição das profissões/ocupações na totalidade da representação parlamentar. Agora, procuraremos indicar as relações entre a composição das bancadas e suas orientações ideológicas. Para uma primeira visualização, os partidos estarão agrupados em três blocos ideológicos ao longo do eixo direita-centroesquerda, cada bloco com dois dos partidos, de acordo com a definição ideológica estabelecida no início do capítulo 2.

Para os cálculos porcentuais, os números absolutos de deputados dos dois partidos de cada tendência ideológica foram somados, sendo a base de cálculo porcentual o número total de parlamentares de cada bloco. Desse modo, as profissões/ocupações dos partidos com bancadas numericamente maiores pesam mais na composição dos blocos ideológicos, o que deve ser levado em conta.

Antes de iniciarmos o exame da distribuição ocupacional nos blocos, convém destacar dois aspectos principais:

1) A pequena variação de setores sociais nos recrutamentos partidários: empresários, profissionais liberais, funcionários públicos $\mathrm{e}$ professores; dos quais vem a maior parte dos integrantes da classe política.

2) A sobrerrepresentação de alguns desses setores em cada bloco segundo o perfil ideológico dos partidos. 


\section{A distribuição das profissões}

No conjunto, percebe-se, pelo exame da Tabela 1 (infra), que a distribuição relativa dos grupos de ocupação/profissão tende a ser coerente com as etiquetas ideológicas dos seis partidos, quero dizer, com as orientações políticas e ideológicas que se espera de segmentos ocupacionais localizados diferentemente na escala social. Focalizando os três blocos ideológicos, vê-se que, no da direita, os deputados que tiveram (ou têm) atividades empresariais perfazem cerca de $64 \%$ do bloco; a proporção de empresários cai para $42 \%$ entre os parlamentares dos partidos de centro e desce ainda mais entre os partidos de esquerda (8\%). Na extremidade mais baixa da escala social, deputados que foram trabalhadores industriais e lavradores chegam a $10 \%$ no bloco de esquerda contra $0,6 \%$ no da direita. Somando a eles os empregados não manuais em serviços $(12 \%$, em porcentagem redonda), esses parlamentares de origem popular ou de classe média representam $22 \%$ dos membros das bancadas dos partidos de esquerda e 2\% nas bancadas dos de direita. Essas categorias "populares" estão ausentes entre os partidos de centro (Cf. anexo 1).

Os parlamentares que, antes de se tornarem políticos profissionais, tinham profissões/ocupações liberais e intelectuais distribuem-se de modo relativamente semelhante nos blocos de centro e de esquerda (mais ou menos um terço), mas estão em proporção um pouco menor no bloco da direita. Já a proporção de parlamentares que eram professores tende a crescer conforme se vai da direita para a esquerda. No bloco PDT/PT chega a $30 \%$, contra $9 \%$ no bloco PPB/PFL.

Os pastores e padres estão em maior número na direita e na esquerda do que no centro, mas lidamos com um número pequeno de casos, o que permite supor que a relação de causa e efeito (profissão religiosa-ideologia) possa não existir.

Os casos de parlamentares que "sempre foram políticos", quero dizer, que se elegeram muito cedo para alguma função de representação política e nunca exerceram outra atividade além da de "político profissional", estão no bloco de centro, e no de esquerda. Mas, tal como no caso das profissões religiosas, seu número é muito pequeno para indicar uma tendência. Assim, para resumir:
No bloco da direita, após os empresários, vêm os parlamentares que foram profissionais liberais e, depois, os que tinham cargos públicos elevados, sendo essas duas últimas categorias praticamente equivalentes. A proporção de ex-professores é baixa (cerca de 8\%).

No bloco do centro, a proporção de empresários (em comparação com o bloco da direita) diminui cerca de vinte pontos percentuais enquanto a de ex-profissionais liberais aumenta nove pontos, ficando a de exfuncionários praticamente igual à da encontrada na direita. A de exprofessores eleva-se para $16 \%$.

No bloco da esquerda, o peso dos empresários, da alta burocracia e da tecnocracia governamental declina acentuadamente. A proporção de parlamentares vindos do magistério sobe para $30 \%$, quase o dobro da encontrada no centro e 3,5 vezes a da encontrada na direita. Neste bloco, a proporção de deputados que foram empregados não manuais em serviços, operários industriais e lavradores forma a terceira categoria, depois dos profissionais liberais e dos professores. $\mathrm{Na}$ realidade, as profissões liberais tradicionais compõem um grupo ocupacional fortemente representado nos três blocos ideológicos. O fato é indicativo de que se trata de um ramo de atividade internamente bastante heterogêneo. Alguns grandes nomes, de muita legitimidade, podem conseguir uma taxa elevada de conversão de capital cultural e intelectual em capital econômico e chegar a rendimentos muito altos, superiores a de muitos empresários. Outros (principalmente jovens em início de carreira) podem estar nos estratos intermediários de renda e status. Portanto, o segmento das profissões liberais, em si mesmas, possibilita muita flexibilidade de situações ocupacionais, de status e de renda e, assim, de opções ideológicas e alianças com outros segmentos profissionais e classes sociais.

No conjunto, a distribuição das profissões/ocupações, ou dos segmentos de classe social, ou frações de classe - como se quiser encontrada nas bancadas partidárias coincide amplamente com a relação clássica entre posição social e orientação política:

1. Alta proporção de empresários na direita, menor proporção no centro e quase inexistente na esquerda.

2. Alta proporção de deputados que exerceram profissões liberais e intelectuais nos três blocos, embora um pouco mais elevada no do centro e 
principalmente no da esquerda.

3. Forte presença de professores nos partidos de esquerda, e mais fraca entre os partidos de centro e de direita.

4. Muitos funcionários das altas administrações públicas dos Estados e da União nos partidos de direita e de centro.

5. Proporção de trabalhadores manuais e empregados não manuais no interior das bancadas dos partidos de esquerda muito mais elevada do que a encontrada nos partidos de direita e de centro. ${ }^{1}$

Tabela 1

Principais grupos de profissões/ocupações por bloco ideológico (\%)

\begin{tabular}{c|c|c|c|c} 
Profissões/Ocupações & $\begin{array}{c}\text { Direita } \\
\text { PPB/PFL }\end{array}$ & $\begin{array}{c}\text { Centro } \\
\text { PMDB/PSDB }\end{array}$ & $\begin{array}{c}\text { Esquerda } \\
\text { PDT/PT }\end{array}$ & Total \\
\hline Empresários & 63,6 & 42,3 & 8,4 & 43,5 \\
\hline Profissões liberais & 21,2 & 30,2 & 33,3 & 27,1 \\
\hline Setor público & 20,6 & 20,9 & 6,0 & 17,5 \\
\hline Magistério & 8,5 & 15,9 & 29,7 & 15,8
\end{tabular}

Esses dados dão uma indicação geral das principais fontes de recrutamento partidário cruzadas por bloco ideológico. As categorias profissionais/ocupacionais foram apresentadas de modo agregado para facilitar a visualização, o que deixou de lado outras categorias de frequência menor e as subdivisões inferiores. Mas elas estão apresentadas de modo mais detalhado no anexo 1.

\section{Os perfis partidários}

Examinamos a relação profissão/ocupação, para fins de uma primeira abordagem, em pares de direita, centro e esquerda (tabela 1, supra), os quais serão agora analisados separadamente a fim de detectar as especificidades entre os partidos de cada bloco ideológico. Desagregados os blocos, a

\footnotetext{
${ }^{1}$ Para facilidade de expressão, na maioria das vezes, falamos no presente quando nos referimos à formação profissional dos parlamentares. De fato, em muitos casos, talvez na maioria, antes de cada profissão/ocupação deveria se antepor o prefixo "ex": ex-professores, ex-advogados etc., porque a ocupação não é mais exercida com a entrada na classe política. Não acontece a mesma coisa com os empresários, especialmente os proprietários, que podem, mesmo à distância, manter-se na direção de seus empreendimentos. Em alguns casos, a atividade político-parlamentar pode, até mesmo, ajudar os negócios.
}

análise de cada legenda isolada mostrou que os traços principais que singularizavam os pares persistem em cada partido integrante, o que reforça, por outro ângulo, a classificação ideológica de cada partido. Mas a desagregação revelou também diferenças significativas que individualizam os dois partidos de cada um dos três blocos. Do ângulo de nosso objetivo, as legendas partidárias que compõem a direita, o centro e a esquerda, apesar de poderem ser reunidas numa mesma configuração programática e política, têm diferenças significativas quanto a aspectos de sua composição social.

Tabela 2

Principais grupos de profissões/ocupações por partido (\%)

\begin{tabular}{c|c|c|c|c|c|c|c} 
Profissões/Ocupações & PPB & PFL & PMDB & $\begin{array}{c}\text { Partido } \\
\text { PSDB }\end{array}$ & PDT & PT & CD \\
\hline Empresários & 68,4 & 60,9 & 46,9 & 38,4 & 20,0 & 3,4 & 43,5 \\
\hline Profis. liberais & 18,3 & 22,9 & 28,9 & 31,3 & 52,0 & 25,4 & 27,1 \\
\hline Setor público & 15,0 & 23,8 & 22,9 & 19,3 & 12,0 & 3,4 & 17,5 \\
\hline Magistério & 6,7 & 9,6 & 15,6 & 16,2 & 20,0 & 33,9 & 15,8 \\
\hline N & 60 & 105 & 83 & 99 & 25 & 59 & 513
\end{tabular}

Claramente, a proporção de empresários (todos os tipos) declina quando se passa da direita para a esquerda. A proporção de profissionais liberais tradicionais tem um desenvolvimento mais complexo. Do PFL até o PDT, aumenta a importância dos deputados que exerceram atividades liberais. A bancada do PPB é a que tem menos deputados desse segmento. O PT vem em seguida. Esses dois partidos estão abaixo da proporção encontrada na CD. Com relação ao setor público (todos os níveis da administração incluídos), a tendência é de diminuição de parlamentares vindos do funcionalismo à medida que se passa dos partidos de direita para os de esquerda. Mas o PPB constitui exceção porque tem relativamente menos ex-funcionários do que o PFL e do que os dois partidos de centro. No PT, a proporção de funcionários é muito pequena. No caso do magistério (todos os níveis docentes), a tendência é bastante nítida: a presença de professores nas bancadas aumenta linearmente quando se vai da direita para a esquerda. O PPB é a legenda cuja bancada tem menos professores; a do PT é a que tem mais, com uma diferença de 27 pontos porcentuais entre os dois partidos. 
Essas observações, baseadas na tabela 2, visam oferecer uma rápida caracterização socio-ocupacional dos partidos. Nas páginas que se seguem esses grupos serão analisados mais detalhadamente a fim de se destacar as particularidades de cada um deles.

\section{Os Empresários}

À direita, tanto no PPB como no PFL, os deputados que tinham (ou tiveram) ocupações de tipo empresarial (urbana/rural) perfazem mais do que a maioria absoluta das bancadas, com o PPB (68\%) superando o PFL (61\%). A categoria dos empresários é também alta no PMDB (47\%); declina entre os parlamentares do PSDB (38\%); cai para 20\% no PDT e é praticamente inexistente no PT (3\%). ${ }^{2}$ Assim, PPB, PFL e PMDB têm, em suas bancadas, proporção mais elevada de empresários do que a existente no conjunto da CD $(43,5 \%)$.

\begin{tabular}{l|c|c|c|c|c|c}
\multicolumn{7}{c}{ Empresários (todos os setores) } \\
PPB & PFL & PMDB & PSDB & PDT & PT & Total da CD \\
\hline 68,4 & 60,9 & 46,9 & 38,4 & 20,0 & 3,4 & 43,5
\end{tabular}

Na desagregação dos tipos de atividades empresariais (urbana, rural e mista), o PPB continua majoritário nos três subsetores, mesmo que o PFL, como veremos mais adiante, possua a maior proporção de parlamentares na faixa patrimonial mais alta. As bancadas do PPB, PFL e PMDB têm, cada uma, porcentagens de deputados que foram (ou são) empresários superiores à do total da $\mathrm{CD}$. A presença de empresários no PMDB é relativamente elevada, acima da existente na Câmara. Uma diferença importante separa especificamente o PSDB dos dois partidos de direita e também do PMDB. Entre os tucanos, a porcentagem de empresários rurais é bastante baixa (8\%), ao passo que, no PMDB, chega a $12 \%$, subindo para $15 \%$ no PFL e para $17 \%$ no PPB. Já no tocante à proporção de empresários do setor

\footnotetext{
${ }^{2}$ Convém relembrar que não está sendo considerada a dimensão do empreendimento empresarial e nem tampouco estão separados proprietários e diretores, gerentes e administra dores assalariados. Essa diferenciação não pôde ser feita neste trabalho, mas, para informações mais detalhadas sobre a composição do grupo empresarial na $\mathrm{CD}$, cf. Silva
} (2002). urbano, os tucanos estão mais perto do PMDB. No bloco dos partidos de esquerda, a diferença entre PDT e PT é acentuada.

\begin{tabular}{l|c|c|c|c|c|c} 
Empresários urbanos \\
PPB & PFL & PMDB & PSDB & PDT & PT & Total da CD \\
\hline 40,0 & 40,0 & 30,1 & 27,3 & 12,0 & 3,4 & 28,5
\end{tabular}

Na comparação entre os setores, em todos os partidos, a proporção de empresários rurais é inferior à de empresários do setor urbano, fato indicativo de uma menor participação direta dos empresários rurais na política nacional. Mas não há alteração na distribuição relativa por legenda embora, nesse ponto, PSDB e PDT praticamente não se diferenciem.

\begin{tabular}{c|c|c|c|c|c|c} 
Empresários rurais \\
PPB & PFL & PMDB & PSDB & PDT & PT & Total da CD \\
\hline 16,7 & 15,2 & 12,0 & 8,1 & 8,0 & - & 10,1
\end{tabular}

As mesmas observações podem ser estendidas para a subcategoria dos empresários com atividades mistas, com os dois partidos de direita e mais o PMDB possuindo mais empresários do setor do que a proporção existente na totalidade da CD. Por isso, levando em conta o espaço ocupado por empresários na bancada do PMDB, talvez a localização mais correta para os peemedebistas seria no centro-direita.

\begin{tabular}{l|c|c|c|c|c|c} 
Empresários em atividades mistas \\
PPB & PFL & PMDB & PSDB & PDT & PT & Total da CD \\
\hline 11,7 & 5,7 & 4,8 & 3,0 & - & - & 4,9
\end{tabular}

\section{As Profissões Liberais}

Trata-se de um grupo ocupacional com forte presença nas bancadas de todos os partidos (mínimo de 18,0\% no PPB e máximo de 52\% no PDT). Tal como no caso dos professores, a proporção de deputados que foram profissionais liberais tende a aumentar conforme se vai da direita para a esquerda, apesar de a bancada do PT, como já ressaltado, estar abaixo da do PDT e da dos dois partidos de centro e do total da CD. Ainda assim, está acima do PPB e do PFL. 
Obviamente, a proporção de cada categoria profissional nas bancadas varia em relação à proporção da participação das outras categorias. Se os empresários, por exemplo, são fortemente representados numa bancada, nela sobra menos espaço para outras profissões/ocupações. Nos dois partidos de direita, é a forte presença dos empresários, o que reduz o peso dos profissionais liberais. No caso do PT, o espaço dos profissionais liberais é diminuído em razão do número elevado de deputados petistas que eram professores, empregados de serviços, trabalhadores manuais e lavradores. Apesar disso, uma forte presença das profissões liberais e intelectuais na representação parlamentar tende a ser um indicador de disposições políticas e ideológicas partidárias mais à esquerda, embora seja um indicador menos forte do que o volume de deputados originários das classes assalariadas, exsindicalistas, na maioria dos casos.

Profissões liberais tradicionais

\begin{tabular}{c|c|c|c|c|c|c} 
PPB & PFL & PMDB & PSDB & PDT & PT & Total da CD \\
\hline 18,3 & 22,9 & 28,9 & 31,3 & 52,0 & 25,4 & 27,1
\end{tabular}

\section{As Profissões Intelectuais}

O número de parlamentares das profissões liberais tradicionais, como já vimos, é muito superior ao das demais profissões de nível superior que foram aqui designadas como "profissões intelectuais". 3 As bancadas do PPB e do PFL são as que possuem as menores proporções de deputados dessa categoria, o que indicaria uma tendência linear de crescimento da proporção de profissões intelectuais à medida que se vai da direita para a esquerda, se não fosse o fato de a bancada do PT possuir uma proporção mais baixa de profissionais desse segmento do que a do PSDB.

Não parece ocasional o peso proporcionalmente mais elevado das profissões intelectuais no PT e no PSDB (e nos partidos de esquerda de modo geral). Na CD eleita em 1990, 13,5\% dos deputados do PSDB e

\footnotetext{
3 Há relativamente poucos deputados que vieram do que chamamos de profissões intelectuais, isto é, todas as profissões de escolaridade formal de nível superior. A designação foi adotada para distinguir essas profissões do bloco das profissões liberais tradicionais em que estão os médicos, os advogados, os engenheiros e alguns veterinários e farmacêuticos. Nas profissões intelectuais predominam os economistas (seis casos) e os sociólogos (cinco casos).
}

$17,4 \%$ do PT eram formados em ciências humanas, de longe as porcentagens mais elevadas entre os partidos grandes e médios e mais do dobro da porcentagem média da CD (6,7\%). Na legislatura eleita em 1994, a proporção para o PSDB declinou para $8,1 \%$, mas ainda assim continuou superior às dos demais partidos relevantes. No PT, a proporção dos formados em ciências humanas subiu para $16,3 \%$, quase duas vezes e meia a porcentagem do total da CD (6,6\%) (Marques \& Fleischer, 1999, pp. 106 e 107).

Profissões intelectuais

\begin{tabular}{c|c|c|c|c|c|c} 
PPB & PFL & PMDB & PSDB & PDT & PT & Total da CD \\
\hline 1,7 & 1,9 & 2,4 & 9,1 & 8,0 & 5,1 & 4,5
\end{tabular}

\section{Os Professores}

Essa categoria ocupa um espaço importante em todos os seis partidos. Mas chamam a atenção as diferenças de cada bancada. Num movimento inverso ao da categoria dos empresários e no mesmo sentido do das profissões liberais e intelectuais (mas de modo mais acentuado), a porcentagem de professores, como já vimos, tende a crescer conforme se passa da direita para a esquerda. Pode-se, pois, prognosticar que quanto maior a proporção de parlamentares (por extensão, de políticos) que foram professores, mais à esquerda o partido tenderá situar-se. Na bancada do PT, cerca de um terço dos deputados exerciam o magistério antes de entrarem para a classe política; na do PDT, um quinto. ${ }^{4}$

Somente nesses dois partidos de esquerda, a porcentagem de professores é maior do que a existente no total da CD (15,8\%). No PFL, $10 \%$ e, no PPB 7\% vieram do magistério. Nos dois partidos de centro, a proporção de professores está em torno de 16\%, isto é, numa posição intermediária entre os partidos de esquerda e de direita. A maior proporção de professores entre os parlamentares petistas tem a ver com a participação

\footnotetext{
${ }^{4}$ Os professores, muitos da elite acadêmica brasileira, sempre tiveram uma presença forte no PT, tanto na representação parlamentar como no aparelho partidário, para não falar dos simpatizantes e compagnons de route. Dos dezesseis deputados petistas eleitos em 1986 para a $\mathrm{CD}$, cinco eram professores, a categoria mais numerosa. A proporção dos eleitos reflete a de candidatos. Nessa eleição, 19,6\% dos candidatos do PT para a CD eram professores (os metalúrgicos chegaram a 11,4\%) (Rodrigues, 1990).
} 
sindical dos docentes, em especial do setor público. Para as principais lideranças, a instituição sindical serve, inicialmente, de meio de acesso à atividade política não parlamentar e, posteriormente, como possível degrau para a obtenção de algum cargo eletivo, entrada na classe política e consequente abandono da atividade sindical. ${ }^{5}$

Não se deve ver nessa observação nenhum juízo valorativo, contra ou a favor, da passagem do campo de atividades da representação profissional para o da representação política. Um argumento a favor (seguramente endossado pelos dirigentes sindicais que atravessaram a ponte que liga os dois campos) é de que a eleição de dirigentes sindicais aumenta a força dos trabalhadores nos órgãos legislativos, o que parece verdade. Um arrazoado na direção contrária é de que os sindicatos perdem lideranças com mais experiência. Outro argumento contra é de que, ante as chances de transição para o campo político, muitas das ações das lideranças sindicais podem estar basicamente (embora geralmente não de modo explícito) em função da preparação da futura entrada na classe política. Em outros termos: a atuação dos diretores de sindicatos (especialmente as que atraem mais a atenção dos meios de comunicação) pode estar mais em função dos projetos eleitorais dos que conseguiram ascender nas estruturas sindicais do que dos interesses da categoria profissional que representam.

Professores (todos os níveis e setores)

\begin{tabular}{c|c|c|c|c|c|c} 
PPB & PFL & PMDB & PSDB & PDT & PT & Total da CD \\
\hline 6,7 & 9,6 & 15,6 & 16,2 & 20,0 & 33,9 & 15,8
\end{tabular}

A separação da categoria dos professores em "professores do magistério público superior" e em "outros professores", ${ }^{6}$ embora não traga

${ }^{5} \mathrm{O}$ avanço do sindicalismo no setor público, principalmente entre funcionários da educação e da saúde, favoreceu, na bancada petista, o aumento do número de professores e médicos. Não se trata de um fenômeno restrito ao Brasil e ao Terceiro Mundo. Em todos os países desenvolvidos, enquanto as taxas de sindicalização do setor de mercado decaíam, aumentavam as do setor público. Uma análise da expansão do sindicalismo de funcionários e de seu declínio entre os trabalhadores industriais e manuais encontra-se em Rodrigues (1999).

6 A categoria "outros professores" engloba principalmente os docentes do ensino superior (23 casos) e um grupo de professores cujo nível e setor empregatício não conseguimos identificar (46 casos). Desconfiamos, porém, que se trata de professores do ensino médio, provavelmente público. As razões vêm do fato de os parlamentares que trabalhavam em diferenças que alterem a tendência geral da concentração dos docentes nos partidos de esquerda, reforça, contudo, algumas diferenças. Está no PT a maior porcentagem de deputados que vieram do ensino público superior (10\%) e, de longe, os que vieram da subcategoria de "outros professores" (24\%), mais do dobro da porcentagem existente no PDT e muitas vezes superior à da existente no PPB (2\%). No total, um terço dos deputados petistas saíram do magistério.

Professores do ensino público superior
\begin{tabular}{c|c|c|c|c|c|c|c} 
PPB & PFL & PMDB & PSDB & PDT & PT & Total da CD \\
\hline 5,0 & 4,8 & 8,4 & 6,1 & 8,0 & 10,2 & 6,4 \\
PPB & PFL & PMDB & PSDB & PDT & PT & Total da CD \\
\hline 1,7 & 4,8 & 7,2 & 10,1 & 12,0 & 23,7 & 9,4
\end{tabular}

\section{Os Funcionários}

Fortes diferenças existem no que tange ao peso das ocupações governamentais nas seis legendas. O PFL, o PMDB e o PSDB são os partidos que mais têm ex-funcionários públicos: cerca de um quinto de seus parlamentares vieram desse setor (excluindo os professores). No PPB, a proporção de funcionários públicos é relativamente baixa (15\%) e no PT ainda mais (3\%). Mas, se contássemos os professores do setor público superior que têm emprego no Estado, a proporção de funcionários aumentaria no $\mathrm{PT}^{7}$ A dimensão do espaço da burocracia pública em cada

instituições mais legítimas c importantes (as grandes universidades) geralmente não deixavam de assinalar as universidades em que se formaram. Consequentemente, oferecem a informação. Já as razões da suspeita de se tratar do ensino público vêm do fato de que a atividade sindical na área da educação, essencial para a entrada de professores de renda média na classe política, localiza-se essencialmente no setor público.

7 André Marenco dos Santos encontrou, para a CD eleita em 1994, 3,4\% de funcionários públicos no PFL e observou um declínio persistente do segmento dos funcionários públicos entre os parlamentares (Santos, 1997, p. 93). Mas, como indica outro trabalho do mesmo autor, a proporção de funcionários, que vinha declinando (20,3\% em 1954 para 8,3\% em 1990 e 9\% em 1994) (Santos, 1997, p. 93), elevou-se significativamente nas eleições de 1998 (Santos, 2000). Para a CD da 51ª Legislatura, a porcentagem de funcionários 
legenda tende a declinar quase linearmente conforme se vai da direita para a esquerda, sendo o PPB a exceção.

Ocupações governamentais (todos os níveis)

\begin{tabular}{c|c|c|c|c|c|c} 
PPB & PFL & PMDB & PSDB & PDT & PT & Total da CD \\
\hline 15,0 & 23,8 & 22,9 & 19,3 & 12,0 & 3,4 & 17,5
\end{tabular}

As ocupações governamentais, quando decompostas por níveis de governo, mostram algumas diferenças que distinguem os partidos dentro dos blocos ideológicos. A grande diferença, no caso do PFL, que eleva o espaço dos funcionários em sua bancada, é a elevada proporção $(11 \%)$ de seus deputados que ocupavam altos postos da administração federal, mais do que o dobro da de parlamentares do mesmo setor na CD (5\%). Desse segmento do alto funcionalismo federal não há nenhum membro nas bancadas do PDT e na do PT e somente 3\% na do PPB. Mas o PFL tem também uma elevada parcela de deputados que possuíam altos postos na administração pública estadual (11\%). Nesse plano, é superado somente pelo PMDB (16\%).

Na bancada do PT, na qual é muito baixa a proporção de funcionários, nenhum dos seus parlamentares ocupava alto posto na burocracia federal. Provavelmente, o número elevado de deputados do PFL que foram altos funcionários dos governos federal e estaduais antes de se elegerem pela primeira vez - e do PMDB, no que diz respeito aos governos estaduais - explica-se pelo tempo que esses partidos estiveram no governo. De todo jeito, qualquer que seja a razão, o dado sugere estreita vinculação do PFL com a alta administração pública, devendo-se notar que somente $2 \%$ dos membros de sua bancada vieram do baixo funcionalismo.

Altos funcionários da administração federal

\begin{tabular}{c|c|c|c|c|c|c} 
PPB & PFL & PMDB & PSDB & PDT & PT & Total da CD \\
\hline 3,3 & 10,5 & 4,8 & 6,1 & - & - & 4,9
\end{tabular}

apresentada por Marenco dos Santos está muito próxima da nossa: 17,9\% e 17,5\%, respectivamente.
Altos funcionários da administração estadual

\begin{tabular}{c|c|c|c|c|c|c} 
PPB & PFL & PMDB & PSDB & PDT & PT & Total da CD \\
\hline 8,3 & 11,4 & 15,7 & 6,1 & 8,0 & 1,7 & 9,0
\end{tabular}

Altos funcionários da administração municipal

\begin{tabular}{|c|c|c|c|c|c|c|}
\hline PPB & PFL & PMDB & PSDB & PDT & PT & Total da CD \\
\hline 1,7 & - & 1,2 & 5,1 & 4,0 & - & 1,8 \\
\hline \multicolumn{7}{|c|}{ Baixo e médio funcionalismo público } \\
\hline PPB & PFL & PMDB & PSDB & PDT & $\mathrm{PT}$ & Total da CD \\
\hline 1,7 & 1,9 & 1,2 & 2,0 & - & 1,7 & 1,8 \\
\hline
\end{tabular}

As categorias profissionais e ocupacionais minoritárias

As profissões/ocupações mencionadas acima são, de longe, as mais comuns entre os parlamentares. Além de relativamente numerosas no mercado de trabalho, são também as que mais adequadamente preparam e motivam para a atividade política, traço que parece o mais importante. Mas convém apontar, para permitir uma visão mais abrangente da composição da atual legislatura, as proporções de parlamentares que tinham outras profissões/ocupações antes de serem eleitos pela primeira vez para algum cargo eletivo.

Os pastores e padres compreendem 10\% dos deputados do PPB, mas somente $2 \%$ dos do PFL. Essa proporção do PPB é elevada se lembrarmos que, nas ocupações religiosas, estão apenas $4 \%$ do total de parlamentares. Nos demais partidos examinados, a proporção de pastores e padres é pequena, com a exceção do PDT, no qual se encontram $4 \%$.

\section{As Classes Populares}

$\mathrm{Na}$ categoria dos empregados não manuais do setor de serviço (bancários e técnicos, na maior parte), não se encontrou nenhum deputado do PSDB, do PMDB e do PDT. No PFL e no PPB, há menos de $2 \%$. No PT, pula para $17 \%$. Nesse partido, a porcentagem de trabalhadores manuais qualificados é de $9 \%$; no PFL, de $1 \%$. Nas bancadas dos outros partidos não há ninguém originário da classe operária industrial. Os deputados que eram 
lavradores e trabalhadores rurais são apenas $0,6 \%$ das cadeiras. Em números absolutos, são apenas três, dos quais os dois do PT eram dirigentes sindicais antes de serem eleitos.

No total de deputados da CD de "origem operária" ou "popular", $86 \%$ foram dirigentes sindicais ( 21 casos). No total de deputados petistas da mesma origem social, todos foram sindicalistas; dos vinte ex-professores do mesmo partido, onze vieram do sindicalismo.

Esses últimos segmentos, que formam o que se poderia chamar de representação popular na $\mathrm{CD}$, não chegam a $5 \%$ do total de parlamentares. Sua distribuição por legenda é bastante diferenciada.

No PSDB, PMDB e PDT inexistem deputados que tivessem sido, em sua última ocupação, empregados, operários ou lavradores. ${ }^{8}$ Nos dois partidos de direita, a porcentagem de deputados de "origem popular" ou de "classe média-baixa" (a classificação é necessariamente genérica) é quase inexistente, ao passo que chega a $31 \%$ na bancada petista, o que significa cerca de seis vezes a proporção de parlamentares dessa origem na CD (5\%). Assim, o que não deveria surpreender, o peso de deputados "vindos de baixo" aumenta à medida que se vai da direita para a esquerda. Mas deve-se observar que, na bancada do PDT, não há nenhum deputado dos segmentos populares.

Empregados, operários e lavradores

\begin{tabular}{c|c|c|c|c|c|c} 
PPB & PFL & PMDB & PSDB & PDT & PT & Total da CD \\
\hline 1,7 & 2,0 & - & - & - & 30,5 & 4,7
\end{tabular}

\footnotetext{
${ }^{8}$ Stricto sensu, talvez fosse mais correto classificar profissionalmente a maioria desses casos como "sindicalistas" ou como "diretores de sindicatos" porque, antes de entrarem para a classe política, passaram um bom período na direção de entidades sindicais. Segundo cálculos do DIAP (Boletim, outubro de 1998), 39 sindicalistas foram eleitos para a CD, dos quais 34 pelo PT, três pelo PC do B, um pelo PFL e um pelo PPB. Entre os petistas, a grande maioria poderia ser classificada genericamente como sendo de classe média, entre os quais, havia sete professores, cinco metalúrgicos e cinco bancários, as categorias mais numerosas. A lista do DIAP inclui entre os sindicalistas um deputado do PT gaúcho que, no Repertório Bibliográfico, se definiu como "advogado e empresário". Contudo, pelos critérios que estabelecemos, foi classificado como empresário (provavelmente seria um pequeno empresário). Sendo assim, a proporção de sindicalistas do PT diminui ligeiramente, de 34 para 33 parlamentares.
}

A proporção de empregados, operários industriais e lavradores na bancada do PT é cerca de 6,5 vezes à do total da $\mathrm{CD}$ e destoa fortemente da dos demais partidos. Mas, pelos dados das eleições de 1998, a fração de trabalhadores eleitos pela bancada petista parece estar em declínio enquanto a dos de estratos médios parece estar aumentando. Para a $51^{\mathrm{a}}$ Legislatura, entre os 59 deputados do PT eleitos, 28 (47\%) chegaram à CD pela primeira vez. Entre esses, apenas um era operário (metalúrgico e dirigente sindical). Em contrapartida, onze professores (39\%) estavam entre os recémchegados. Pode-se ver aqui, novamente, o declínio dos sindicatos dos metalúrgicos (dos quais provinha a maior parte dos operários que conseguiam chegar à $\mathrm{CD}$ ) e a ascensão do sindicalismo do setor público e de classe média. 


\section{PATRIMÔNIO, PARTIDO E OCUPAÇÃO}

Este capítulo traz os dados relativos às declarações de bens dos parlamentares. $\mathrm{O}$ cruzamento dos valores patrimoniais com as profissões/ocupações e com as legendas partidárias mostrou-se congruente com a classificação ideológica dos partidos e com a distribuição socioocupacional das bancadas.

\section{As declarações de bens}

O exame das declarações de bens dos deputados da $51^{\text {a }}$ Legislatura, que indica a dimensão do patrimônio, forneceu outros elementos para a localização dos parlamentares no espaço social ou, no jargão marxista, para o exame do "caráter de classe" da organização partidária. Convém esclarecer que se trata da declaração de bens e não da de renda e, portanto, não dizem respeito aos ganhos dos parlamentares, mas ao seu patrimônio. ${ }^{1}$

Foram aproveitadas para a pesquisa 401 declarações de bens. Faltaram, pois, 112 de seis Estados. ${ }^{2}$ Embora representem 78,2\% da CD, as 401 declarações não são representativas do total de parlamentares porque não se trata de uma amostra uma vez que seis unidades da Federação ficaram integralmente excluídas. Por isso, os dados sobre os bens dos membros das bancadas dos seis partidos devem ser tomados como indicação que somente sugerem tendências e situações. Em contraposição - e nesse ponto de modo mais seguro - , as declarações referentes aos 21 Estados serviram como controle das reclassificações que procedemos das profissões/ocupações declaradas no Repertório. Mas, se as 401 declarações de bens não valem como representativas do universo da $\mathrm{CD}$, dão-nos dados completos sobre o subuniverso de todos os parlamentares de 21 unidades da

\footnotetext{
${ }^{1}$ Para registro da candidatura no Tribunal Regional Eleitoral, os candidatos devem entregar, juntamente com outros documentos, uma declaração de seus bens (lei 9.504/97, artigo 11). Amazonas, Bahia, Goiás, Sergipe, Maranhão e Paraíba. Além das declarações que faltaram desses Estados, por vários motivos, outras não puderam ser aproveitadas (mais informações no capítulo 10, "Procedimento Metodológico").
}

Federação, fato que permitiu a construção das seguintes faixas patrimoniais (valores declarados em 1998 e referentes ao exercício de 1997).

Quadro 3

Faixas de patrimônio

\begin{tabular}{|l|r|}
\hline Baixo patrimônio & Menos de $200 \mathrm{mil}$ \\
\hline Médio-baixo patrimônio & 200 mil a menos de $500 \mathrm{mil}$ \\
\hline Médio-alto patrimônio & De 500 mil a 2 milhões \\
\hline Alto patrimônio & Mais de 2 milhões \\
\hline
\end{tabular}

$\mathrm{O}$ exame do quadro abaixo mostra que pouco mais da metade dos 401 deputados estão nas faixas de médio-baixo e baixo patrimônio. Cerca de $30 \%$ declararam bens no valor inferior a 200 mil reais, valor que chamamos de "baixo patrimônio". Na faixa com patrimônio superior a 2 milhões de reais estão $16 \%$ dos 401 deputados.

Quadro 4

Distribuição dos deputados por faixa patrimonial

\begin{tabular}{|c|c|c|}
\hline Faixas patrimoniais & $\mathrm{N}$ & $\%$ \\
\hline Baixo patrimônio & 112 & 27,9 \\
\hline Médio-baixo & 106 & 26,5 \\
\hline Médio-alto & 120 & 29,9 \\
\hline Alto & 63 & 15,7 \\
\hline Total & 401 & 100,0 \\
\hline
\end{tabular}

O exame do patrimônio dos deputados dos 21 Estados revelou um padrão de distribuição por partido congruente com os achados relativos à distribuição das ocupações/profissões das bancadas na $\mathrm{CD}$ e com a ideologia dos partidos. Conforme se vai da direita para a esquerda do espectro ideológico, a porcentagem de deputados nas faixas de valor patrimonial mais elevado tende a decrescer no interior das bancadas. Em outras palavras: os partidos cuja proporção de membros de suas bancadas que foram (ou são) empresários é alta têm relativamente mais deputados nas faixas de maior patrimônio, ou seja, o PFL e o PPB. Os partidos com menos empresários têm uma proporção mais baixa de parlamentares com

${ }^{3}$ A fixação do número de faixas (quatro) e de seus limites foi feita após o exame da distribuição de todos os valores individuais. Combinou-se dois critérios: diferenças relativamente significativas entre as fronteiras e número de casos que permitisse cruzamentos com outras variáveis. 
patrimônio elevado (PMDB e PSDB), enquanto os partidos que têm pouquíssimos empresários entre seus deputados têm uma bancada parlamentar com patrimônio mais baixo (PDT e PT).

Sob esse enfoque, e de modo um pouco caricatural, PFL e PPB formariam a "classe alta" dos partidos; o PMDB e o PSDB, a "classe média" e PDT e PT, a "classe baixa". Cabe ressalvar, porém, que o PDT, do prisma patrimonial, está mais próximo do PSDB e do PMDB do que do PT, o que, novamente, vai a favor da conceituação do PDT como centroesquerda. O PFL, em comparação com o $\mathrm{PPB}$, tem maior proporção de deputados na faixa de patrimônio mais elevado (29\% contra 22\%). Caso os dados da Bahia estivessem incluídos, a diferença a favor do PFL provavelmente ficaria maior porque $44 \%$ dos deputados baianos eram empresários e dos vinte integrantes da bancada do PFL, exatamente 50\%.

O PSDB e o PMDB, em comparação com os dois partidos mais à direita, têm proporcionalmente, num polo, menos deputados nas faixas de patrimônio elevado, mas, no polo oposto, proporcionalmente menos do que o PDT e o PT nas faixas de baixo patrimônio (tabela 3, infra). Na comparação entre os dois partidos do centro, os parlamentares do PMDB declararam bens de valor um pouco mais elevado do que os do PSDB, aliás, como seria de se esperar em razão do número menor de empresários entre os tucanos. O PT não possui nenhum deputado nas faixas com elevado e médio-alto patrimônio enquanto o PDT possui $9 \%$ na de alto e $18 \%$ na de médio-alto. Mais indicativo, talvez, do patrimônio mais baixo dos deputados petistas na comparação com os pedetistas é a proporção dos parlamentares dos dois partidos de esquerda na faixa patrimonial mais baixa: $80 \%$ dos deputados do PT contra $41 \%$ do PDT. $^{4}$
Tabela 3

Distribuição interpartidária do patrimônio

\begin{tabular}{c|c|c|c|c|c}
\multirow{2}{*}{ Partido } & \multirow{2}{*}{ Baixo } & \multicolumn{2}{|c|}{ Faixas patrimoniais } & \multirow{2}{*}{ Alto } & \multirow{2}{*}{} \\
\cline { 3 - 4 } & & Médio-Baixo & Médio-Alto & & \\
\hline PT & 80,4 & 19,6 & 0 & 0 & 51 \\
\hline PDT & 40,9 & 31,8 & 18,2 & 9,1 & 22 \\
\hline PMDB & 19,3 & 24,2 & 40,4 & 16,1 & 62 \\
\hline PSDB & 20,2 & 30,9 & 35,8 & 13,1 & 84 \\
\hline PFL & 12,8 & 24,3 & 34,3 & 28,6 & 70 \\
\hline PPB & 9,8 & 23,5 & 45,1 & 21,6 & 51 \\
\hline Outros & 31,1 & 31,1 & 23,0 & 14,8 & 61
\end{tabular}

Em todos os seis partidos houve parlamentares que declararam um patrimônio baixo. Nessa faixa, estão cerca de $30 \%$ dos membros da CD. Tomando como critério a proporção de deputados nas faixas de alto e de médio-alto patrimônio, as bancadas partidárias dessa $51^{\text {a }}$ Legislatura poderiam ser assim ordenadas em ordem decrescente de riqueza ${ }^{5}$ :

Quadro 5

Classificação dos partidos nas faixas patrimoniais

\begin{tabular}{|c|c|c|c|}
\hline Alto patrimônio & $(\%)$ & Alto + médio-alto patrimônios & $(\%)$ \\
\hline $1^{\circ} \mathrm{PFL}$ & 29 & $1^{\circ} \mathrm{PPB}$ & 67 \\
\hline $2^{\circ} \mathrm{PPB}$ & 22 & $2^{\circ} \mathrm{PFL}$ & 63 \\
\hline $3^{\circ} \mathrm{PMDB}$ & 16 & $3^{\circ} \mathrm{PMDB}$ & 56 \\
\hline $4^{\circ} \mathrm{PSDB}$ & 13 & $4^{\circ} \mathrm{PSDB}$ & 49 \\
\hline $5^{\circ} \mathrm{PDT}$ & 9 & $5^{\circ} \mathrm{PDT}$ & 27 \\
\hline $6^{\circ} \mathrm{PT}$ & - & $6^{\circ} \mathrm{PT}$ & - \\
\hline
\end{tabular}

Nota-se a congruência entre os perfis ideológicos dos partidos, a distribuição socio-ocupacional dos parlamentares e o valor dos bens: as bancadas com mais empresários têm mais parlamentares nas faixas mais elevadas de bens e estão nas legendas que são consideradas de direita. De modo geral, a diminuição da proporção de empresários nas bancadas dos

\footnotetext{
${ }^{5}$ A ordenação tem a ver com a porcentagem de integrantes de cada bancada que estão em cada faixa de patrimônio e nada tem a ver com a média dos valores patrimoniais dos

membros de cada bancada.
}

\footnotetext{
${ }^{4} \mathrm{O}$ fato de $80 \%$ dos membros da bancada do PT localizar-se na faixa de patrimônio mais baixo deve-se provavelmente ao elevado número de seus deputados que foram empregados bancada), além do grande número de professores.
} 
seis partidos coincide com a diminuição da proporção de parlamentares com alto patrimônio.

No caso do PSDB e do PMDB, os empresários têm uma presença importante (46\%, no PMDB; 37\%, no PSDB), mas, ao contrário do que acontece no PFL e no PPB, não formam a maioria das respectivas bancadas. Especialmente entre os tucanos, os profissionais liberais, as profissões intelectuais, os professores, os diretores de bancos estatais ${ }^{6}$ e outros segmentos profissionais de classe alta ou de média-alta são categorias mais representadas do que em outras legendas e repartem o espaço com os empresários. A redução do volume de empresários nesses dois partidos de centro faz com que, em termos do montante do patrimônio, peemedebistas e tucanos situem-se num patamar abaixo de seus colegas do PFL e do PPB. Os partidos considerados como de esquerda, com poucos empresários, são também os que têm, relativamente, o maior número de deputados com patrimônio mais baixo.

O cruzamento da distribuição patrimonial com a distribuição profissão/ocupação mostra que o grupo dos empresários tende a ser o mais rico. Das 401 declarações, 63 deputados (16\%) declararam bens no valor acima de 2 milhões de reais ("alto patrimônio", na nossa classificação). Embora todos nessa faixa fossem empresários, isso não significa que todos os deputados que foram (ou são) empresários têm alto patrimônio. Na faixa mais baixa, por exemplo, havia $11 \%$ de empresários que faziam companhia para $26 \%$ de profissionais liberais, $13 \%$ de ex-funcionários e $28 \%$ de professores.

Mas esses números (que se encontram na tabela 4) precisam ser vistos com cuidado para que um viés não se introduza na interpretação dos dados. A porcentagem de cada faixa é afetada pelo número absoluto de parlamentares existente e m cada categoria profissional. Quanto maior o número de deputados de cada profissão/ocupação, se todos os demais fatores forem iguais, mais elevada é a chance de que haja maior número da categoria em todas as faixas patrimoniais.

${ }^{6}$ Como vimos, 6\% dos membros do PSDB e do PMDB foram diretores de bancos estatais. No PFL e no PPB, assim como no PT, não registramos nenhum caso. No PDT, foram $4 \%$ dos integrantes da bancada.
As porcentagens da tabela 4 indicam as proporções de casos dentro de cada faixa de patrimônio. Por exemplo: a existência de $100 \%$ de empresários na faixa de alto patrimônio significa que dos 63 deputados nessa faixa todos eram empresários. Acontece que, na tabela 4, o cálculo porcentual foi feito tendo como base o número de profissão/ocupação e muitos deputados indicaram mais de uma. Assim, havia empresários que tinham outra profissão. Os profissionais liberais e professores que tinham alto patrimônio eram também empresários, razão pela qual, como dissemos, dos 63 casos de parlamentares de alto patrimônio, todos eram empresários, o que não significa dizer que todos os empresários tivessem alto patrimônio.

Tabela 4

Faixas patrimoniais por profissões/ocupações agregadas

\begin{tabular}{|c|c|c|c|c|}
\hline \multirow{2}{*}{ Profissão/Ocupação } & \multirow{2}{*}{ Baixo } & \multicolumn{2}{|c|}{ Faixas patrimoniais } & \multirow{2}{*}{ Alto } \\
\hline & & Médio-Baixo & Médio-Alto & \\
\hline Empresários & 10,7 & 24,5 & 55,8 & 100,0 \\
\hline Profissionais liberais & 25,9 & 32,1 & 30,0 & 9,5 \\
\hline Setor público & 13,4 & 25,5 & 15,0 & 6,3 \\
\hline Magistério & 27,7 & 16,0 & 15,8 & 4,8 \\
\hline Outras ocupações & 42,84 & 19,82 & 17,6 & 12,73 \\
\hline Soma das \% & 120,54 & 117,92 & 134,2 & 133,3 \\
\hline $\begin{array}{l}\text { Total das ocupações/ } \\
\text { profissões (n.a.) }\end{array}$ & 135 & 125 & 161 & 84 \\
\hline Total de casos (na.) & 112 & 106 & 120 & 63 \\
\hline
\end{tabular}

Obs.: As somas das porcentagens são superiores a $100 \%$ pois alguns deputados possuem mais de uma profissão/ocupação.

Mas a relação entre a dimensão do patrimônio e a ocupação pode também ser investigada de outro ângulo, tomando-se como base de cálculo, não a distribuição de ocupações/profissões no interior de cada faixa patrimonial, mas das faixas patrimoniais no interior das profissões/ocupações. Tem-se, desse modo, outra percepção da distribuição patrimonial dentro de cada categoria ocupacional. 
Focalizada do ângulo das profissões/ocupações, vê-se na tabela 5 (infra) que somente 6\% dos profissionais liberais tinham alto patrimônio. A maior parte, cerca de $67 \%$, estava nas faixas de médio-baixo e médio-alto patrimônios. No grupo dos professores, $44 \%$ estavam na faixa de baixo patrimônio. Nesse enfoque, dos 168 parlamentares classificados como empresários (42\% das 401 declarações de bens), 7,0\% tinham baixo patrimônio, porcentagem relativamente pequena.

Os deputados que vieram do setor público concentram-se nas faixas de baixo e médio-baixo patrimônio (66\%). Mas há também $28 \%$ desse grupo que se localiza na faixa média-alta. Nesse caso, são geralmente deputados que vieram dos altos escalões do governo federal. Entre os dezesseis deputados que ocuparam altos cargos no governo federal, a metade estava na faixa de médio-alto patrimônio. Dos oito casos de parlamentares que eram das administrações municipais, somente um tinha médio-alto patrimônio e nenhum estava na faixa mais elevada.

Dos 21 parlamentares (5\% de 401) que eram operários, empregados não manuais de serviços e lavradores, quinze estavam na faixa de baixo patrimônio, cinco na de médio-baixo e um na de médio-alto. (Esses dados encontram-se nos anexos 3 e 4 e não aparecem na tabela 5.)

Tabela 5

Principais profissões/ocupações agregadas por patrimônio

\begin{tabular}{l|c|c|c|c}
\multirow{2}{*}{$\begin{array}{c}\text { Faixas } \\
\text { patrimoniais }\end{array}$} & \multicolumn{4}{|c}{ Profissões/Ocupações } \\
\cline { 2 - 5 } & Empresários & $\begin{array}{c}\text { Profis. } \\
\text { liberais }\end{array}$ & $\begin{array}{c}\text { Setor } \\
\text { público }\end{array}$ & Magistério \\
\hline Baixo & 7,1 & 27,6 & 23,4 & 44,3 \\
\hline $\begin{array}{l}\text { Médio- } \\
\text { baixo }\end{array}$ & 15,5 & 32,4 & 42,2 & 24,3 \\
\hline Médio-alto & 39,9 & 34,3 & 28,1 & 27,1 \\
\hline Alto & 37,5 & 5,7 & 6,3 & 4,3 \\
\hline $\mathrm{N}$ & 168 & 105 & 64 & 70 \\
\hline Total & 100,0 & 100,0 & 100,0 & 100,0
\end{tabular}

\section{Uma hierarquia das profissões por patrimônio}

A fim de se ter uma visualização mais simples (e grosseira) da hierarquia do patrimônio pela última ocupação dos parlamentares, o quadro
6 traz, em escala decrescente, as ocupações/profissões ordenadas segundo a posição de cada uma delas na soma das porcentagens nas faixas de médioalto + alto patrimônios. A maior proporção de casos de parlamentares com patrimônio superior a 500 mil reais (médio-alto + alto patrimônios) encontra-se entre os deputados que foram diretores de bancos estatais. Trata-se, porém, no total, de somente dez casos. Os empresários são proporcionalmente bem mais numerosos quando se considera somente a faixa de alto patrimônio (acima de 2 milhões de reais). No grupo dos empresários, os de maior patrimônio são os que têm empreendimentos mistos (rurais e urbanos).

Quadro 6

Patrimônio — de casos na faixa média-alta e na faixa alta

\begin{tabular}{|l|l|}
\hline Profissão/Ocupação & $\%$ \\
\hline Diretores de bancos estatais & 80 \\
\hline Empresários mistos & 78 \\
\hline Empresários urbanos & 77 \\
\hline Empresários rurais & 77 \\
\hline "Políticos" & 67 \\
\hline Alto funcionalismo federal & 56 \\
\hline Profissionais liberais tradicionais & 40 \\
\hline Profissões intelectuais & 39 \\
\hline Altos funcionários de administrações estaduais & 39 \\
\hline Outros professores & 32 \\
\hline Pastores e padres & 31 \\
\hline Professores do ensino público superior & 31 \\
\hline Comunicadores & 21 \\
\hline Altos funcionários de administrações municipais & 12 \\
\hline Empregados não manuais de serviços & 9 \\
\hline Baixo e médio funcionalismos & 0 \\
\hline Trabalhadores industriais qualificados & 0 \\
\hline Lavradores & 0 \\
\hline
\end{tabular}


De modo geral, o patrimônio tende a crescer com a idade, o que significa dizer que cresce com o tempo numa (ou mais) atividade ocupacional. No caso dos deputados, tempo na profissão significa também tempo de vida na classe política ou, mais especificamente, número de legislaturas para as quais foi eleito, aí incluindo passagens anteriores por outros cargos eletivos (amiúde, ocupação de algum cargo no setor público por indicação política, sem disputa eleitoral). Há algumas evidências que indicam correlação positiva entre número de legislaturas e aumento do valor dos bens. ${ }^{7}$

Tabela 6

Patrimônio por número de legislatura

\begin{tabular}{l|c|c|c|c|c}
\multirow{2}{*}{$\mathrm{N}^{\mathrm{N}}$ de legislaturas } & \multirow{2}{*}{ Baixo } & \multicolumn{2}{|c|}{ Faixas patrimoniais } & \multirow{2}{*}{ Alto } & \multirow{2}{*}{$\mathrm{N}$} \\
\cline { 3 - 4 } & & Médio-Baixo & Médio-Alto & & \\
\hline Uma & 59,8 & 38,7 & 35,0 & 20,6 & 163 \\
\hline Duas & 25,9 & 34,9 & 30,8 & 31,8 & 123 \\
\hline Três & 9,8 & 17,0 & 19,2 & 23,8 & 67 \\
\hline Quatro ou mais & 4,5 & 9,4 & 15,0 & 23,8 & 48 \\
\hline Total & 100,0 & 100,0 & 100,0 & 100,0 & \\
\hline $\mathrm{N}$ & 112 & 106 & 120 & 63 & 401 \\
\hline
\end{tabular}

Obs.: Foram considerados como estando em "primeira legislatura" os parlamentares que ingressaram na CD pela primeira vez. Casos de retorno após um intervalo não foram considerados como "novatos". 8

As tabelas 6 e 7 referem-se à distribuição patrimonial correlacionada com o número de legislaturas. Por elas, vê-se que a proporção de deputados nas faixas patrimoniais mais altas cresce com o número de legislaturas. A tabela 6 indica que, dos 112 casos de parlamentares que constituem a faixa de baixo patrimônio, $60 \%$ estavam em sua primeira legislatura, enquanto os que tinham quatro ou mais legislaturas eram apenas $5 \%$. No outro extremo, na mesma tabela, vê-se que só $21 \%$ (treze casos) dos que tinham alto patrimônio estavam na primeira legislatura.

\footnotetext{
${ }^{7}$ Uma análise um pouco mais acurada da relação entre a atividade política e o patrimônio necessitaria considerar etapas anteriores da carreira, o que não pudemos fazer aqui.

${ }^{8}$ Esse critério que adotamos difere, por exemplo, do de André Marenco dos Santos que classificou como novatos os parlamentares que além de estarem ingressando na CD faziam
} seu retorno após uma ausência (Santos, 2000, p. 65).
A tabela 7, tendo agora como variável independente o número de legislaturas, mostra como o montante do patrimônio tende a crescer com o tempo de casa: $41 \%$ dos parlamentares com baixo patrimônio estavam na primeira legislatura federal. Dos 163 casos de calouros, 8\% tinham alto patrimônio antes de entrar na $\mathrm{CD}$, o que sugere que já eram ricos, seja por patrimônio próprio seja por tempo em outros cargos eletivos do Legislativo ou do Executivo (vereador, deputado estadual, prefeito). No outro extremo, $31 \%$ dos que tinham quatro ou mais legislaturas estavam na faixa de alto patrimônio. Por essa tabela, vê-se como a proporção de casos na faixa de baixo patrimônio tende a diminuir conforme aumenta o número de legislaturas, enquanto no lado oposto cresce a porcentagem de casos na faixa de alto patrimônio à medida que aumenta o número de legislaturas.

Mas a tabela mostra também que $31 \%$ dos deputados, apesar de estarem com quatro ou mais legislaturas, estavam nas faixas de baixo e médio-baixo patrimônios, o que significa que o patrimônio não aumentou significativamente com o tempo de exercício do mandato. Essa tendência, no entanto, é minoritária porque $69 \%$ dos parlamentares com quatro ou mais legislaturas estavam no grupo de médio-alto e alto patrimônios. No caso dos que estavam na primeira legislatura, a porcentagem dos que tinham médio-alto e alto patrimônios cai para $34 \%$.

\section{Tabela 7}

Legislaturas por faixas patrimoniais

\begin{tabular}{l|c|c|c|c|c|c|c|c|c}
\multirow{2}{*}{ Patrimônio } & \multicolumn{8}{c|}{ Legislaturas } \\
\cline { 2 - 12 } & \multicolumn{2}{|c|}{ Uma } & \multicolumn{2}{|c|}{ Duas } & \multicolumn{2}{c|}{ Três } & \multicolumn{2}{c|}{$\begin{array}{l}\text { Quatro ou } \\
\text { mais }\end{array}$} \\
\cline { 2 - 12 } & $\mathrm{N}$ & $(\%)$ & $\mathrm{N}$ & $(\%)$ & $\mathrm{N}$ & $(\%)$ & $\mathrm{N}$ & $(\%)$ & $\mathrm{N}$ \\
\hline Baixo & 67 & 41,1 & 29 & 23,6 & 11 & 16,4 & 5 & 10,4 & 112 \\
\hline $\begin{array}{l}\text { Médio- } \\
\text { baixo }\end{array}$ & 41 & 25,1 & 37 & 30,1 & 18 & 26,9 & 10 & 20,8 & 106 \\
\hline Médio-alto & 42 & 25,8 & 37 & 30,1 & 23 & 34,3 & 18 & 37,5 & 120 \\
\hline Alto & 13 & 8,0 & 20 & 16,2 & 15 & 22,4 & 15 & 31,3 & 63 \\
\hline $\mathrm{N}$ & 163 & 100,00 & 123 & 100,0 & 67 & 100,0 & 48 & 100,0 & 401
\end{tabular}

É provável que a entrada na classe política possibilite o acréscimo do patrimônio, mas os dados anteriores não constituem exatamente uma prova do enriquecimento por meio da política, ainda que isso possa ter ocorrido. 
Outros fatores que não estão sendo avaliados nesta pesquisa podem ter favorecido o crescimento do patrimônio. Basta lembrar que, para a maioria das pessoas - e os membros da classe política não seriam exceção - o patrimônio tende a aumentar com a idade. De qualquer forma, há muitas indicações, embora não oferecidas por esta pesquisa, de que a própria atividade política - mesmo quando exercida segundo todos os cânones da respeitabilidade e da decência - possibilita não apenas o aumento do poder, da influência e do status (como seria de se esperar), mas também da renda e do patrimônio. Se assim for, a continuidade na $\mathrm{CD}$ por várias legislaturas tenderia, por si mesma, a levar ao crescimento do patrimônio, tanto mais significativo quanto, em termos relativos, mais baixa for a origem socioeconômica do parlamentar ou, mais exatamente, quanto mais baixo eram o status e a renda proporcionados pelo último emprego antes da primeira eleição para uma função pública.

Em outras palavras: a ascensão na escala social é relativamente mais significativa para os membros das classes trabalhadoras e médias que entram e ascendem na política do que para os membros das classes altas, os que já possuíam renda e status elevado, prestígio intelectual, influência social e política e outros atributos que são valorizados nas sociedades ocidentais. Dessas observações não se devem deduzir quaisquer diferenças quanto aos coeficientes de competência e honestidade derivados das origens sociais. Trata-se apenas de mera constatação (de senso comum ainda que talvez não politicamente correta) de que os integrantes da fração parlamentar da classe política que vieram mais de baixo são os que realizam uma ascensão social mais acentuada do que os que vieram mais de cima. ${ }^{9}$

Entretanto, se as tabelas anteriores mostram a tendência para o aumento do valor dos bens em decorrência de uma carreira política de êxito, mostram também que a proporção dos que entram ricos na política é relativamente baixa e que, consequentemente, as portas do sistema político

\footnotetext{
${ }^{9}$ No caso de altas lideranças sindicais - presidentes de centrais, federações e sindicatos importantes - que se deslocam para o campo parlamentar, a mudança pode significar vantagens econômicas e ascensão social, mas nem sempre implica aumento da influência política. Na verdade, pode significar até mesmo redução se o sindicalista não possuir os atributos necessários para a atuação competente na arena parlamentar. Se isso acontecer, o ex-líder sindical perde o controle de uma instituição importante enquanto, na $\mathrm{CD}$, é apenas um em 513.

não estão inteiramente fechadas para os que vieram das classes populares ou das classes médias. Outros trunfos, como sabemos, ajudam na ascensão política: redes familiares, associações e sindicatos, popularidade alcançada em outros setores de atividade, apoio da estrutura partidária etc.

Seguramente, um exame do restante das declarações de bens, dos Estados cujos TRE não as forneceram, poderia levar a correções nos quadros anteriores e, talvez, a pequenas alterações. Além disso, entre as 401 declarações utilizadas na pesquisa, pode ter havido também muitas declarações incompletas, de modo intencional ou não. Mas infelizmente se subestimações ou ocultação de bens aconteceram - não houve maneira de calcular, ou mesmo estimar grosseiramente, a magnitude dos erros e, portanto, em quanto alterariam os valores anteriores. De qualquer forma, como se verificou, houve muita confluência com os dados sobre profissão/ocupação, dimensão do patrimônio e ideologia partidária, o que permite supor que a maior parte das declarações trazia informações confiáveis no sentido de não se afastarem demasiadamente da realidade.

\section{Diferenças internas na representação parlamentar}

Como indicaram as tabelas e quadros anteriores, há na representação parlamentar forte diversidade econômica. $\mathrm{Na} \mathrm{CD}$, formalmente todos os integrantes são iguais entre si, mas, assim como acontece no corpo eleitoral, os eleitores que são também iguais entre si, por possuírem o mesmo número de votos, não o são do ponto de vista social, educacional, econômico, político e de outros atributos. O corpo parlamentar, na realidade, embora cada deputado tenha um voto, é bastante heterogêneo não apenas quanto às filiações partidárias, mas também quanto aos níveis de renda, de educação, de status, de influência política etc.

Além de existir um sistema de estratificação com base nas disparidades de patrimônio e renda, do prisma educacional, a CD possui, num polo, uma elite composta por parlamentares, com elevado nível de escolaridade, alguns com mestrado e doutorado e, no outro, um segmento de baixo nível de educação formal. Mas há outros elementos de diferenciação. Seria possível distinguir também os que vieram da elite e que há gerações ocupam postos no Estado e militam na política (os dois aspectos estão habitualmente relacionados) e os que estão há pouco tempo 
na classe política; os que vieram de famílias tradicionais e os de famílias de imigrantes, com alto ou baixo patrimônios; os que ascenderam com o apoio de redes familiares e os que subiram por esforço próprio. Uma análise da eventual influência desses atributos e das clivagens político-partidárias que podem produzir, das opções partidárias a que podem levar, está fora do alcance deste trabalho. Ficam apenas os dados relacionados à distribuição de bens, a partir dos quais se têm uma ideia da divisão socioeconômica interna da Câmara dos Deputados. Esquematicamente, seguindo as distribuições das profissões/ocupações nas faixas patrimoniais, seria possível distinguir quatro classes.

Os empresários (168 casos) estariam concentrados na classe alta e na média-alta (77\%). Na classe média-baixa estão somente $7 \%$ deles e, na média-média, $15 \%$. Portanto, a tendência predominante dos deputados que eram empresários é de estarem nas duas faixas superiores.

Os profissionais liberais (123 casos) distribuem-se de modo relativamente equitativo pelas classes média-alta (34\%), média-média (31\%) e média-baixa (29\%). (Os 6\% de profissionais liberais que estão na classe alta são também empresários.) Claramente, as profissões liberais admitem situações mais variadas de patrimônio (e provavelmente de renda), com ligeira maioria relativa na classe média-alta. A mesma observação é extensiva às profissões intelectuais, com a ressalva de que uma porcentagem um pouco mais elevada de deputados de profissões intelectuais está no grupo de baixo patrimônio $(40 \%$ e $28 \%$, comparativamente), o que sugere, de modo geral, patrimônios mais baixos para as profissões intelectuais em comparação com as profissões liberais.

Os professores (setenta casos) estão principalmente na classe médiabaixa (44\%). O restante divide-se pelas classes média-média $(24 \%)$ e média-alta $(27 \%)$. Na classe alta, há $4 \%$ de professores, mas ocorre que são também empresários.

Entre os deputados que vieram do setor público (74 casos em 401), dezesseis tinham altos cargos da administração federal: oito estão na classe média-alta, cinco na classe média-média, dois na classe média-baixa e um na classe alta. A alta administração tende, pois, a possibilitar patrimônios mais elevados do que o magistério, as profissões intelectuais e a liberais, pelo menos a julgar pela situação encontrada na $\mathrm{CD}$. Entre os que vieram das administrações públicas estaduais (31 casos), 45\% estão na classe média-média, $29 \%$ na média-alta e $16 \%$ na média-baixa. Vindos das administrações municipais, encontramos oito parlamentares: dois na classe média-baixa, cinco na classe média-média e somente um na classe médiaalta.

Dos dez parlamentares que eram diretores de bancos estatais, dois estão na classe alta, seis estão na classe média-alta, um na classe médiamédia e um na classe média-baixa.

Dos 29 comunicadores, dezessete estão na classe média-baixa; seis na média-média e quatro na média-alta. A maior parte dos comunicadores está, assim, na classe média-baixa, mas dois deputados que estão nessa categoria fazem parte da classe alta (mas são também empresários).

Entre onze empregados não manuais, sete estão na classe médiabaixa, três na média-média e um na média-alta. Dos sete trabalhadores manuais qualificados, cinco estão na classe média-baixa e dois na classe média- média. Os três lavradores estão todos na classe média-baixa, o que não é surpreendente (ver anexo 4).

Para finalizar, convém dizer outra vez que a inserção dos casos em cada uma das classes elaboradas se fez a partir do valor patrimonial das 401 declarações de bens dos parlamentares e não do total dos 513 deputados. Além disso, independentemente do setor de atividade ocupacional ou da profissão, o valor do patrimônio é afetado por muitas outras variáveis, sendo a idade e o tempo na $C D$ duas variáveis importantes. Para a totalidade da CD existe, portanto, uma margem de erro que não é possível calcular. Os valores na delimitação das classes e as categorias ocupacionais que a integraram devem ser tomados somente como indicações da estratificação social entre os parlamentares da $51^{\mathrm{a}}$ Legislatura. 


\section{INSTRUÇÃO E PARTIDO}

Este capítulo divide-se em duas partes: a primeira traz os dados sobre a formação educacional dos parlamentares distribuídos por legenda. Direito, seguido de Medicina são os diplomas mais comuns. A segunda parte mostra a composição social dominante de cada bancada formada pelos segmentos profissionais e ocupacionais dos quais foram recrutados majoritariamente os parlamentares de cada bancada.

A avaliação dos níveis de escolaridade dos parlamentares e de sua formação universitária traz outros elementos para a caracterização dos seis partidos. De modo geral, os níveis de escolaridade do total dos deputados são elevados: $82 \%$ têm algum diploma de curso superior ${ }^{1}$ (tabela 8 ), o que indica que as pessoas com baixa escolaridade têm mínimas chances de chegar a deputado federal. Mas alguns chegam. Do total de deputados (todas as legendas incluídas), $4 \%$ não completaram o segundo grau. Como tendência, os partidos mais à esquerda, comparativamente, têm mais parlamentares com mestrado/doutorado completo do que os partidos de direita. O PT é o partido com a maior porcentagem de deputados com pósgraduação (14\%), bem mais do que o PFL e o PPB (apenas 5\% e 7\%, respectivamente).

Depois da bancada petista, PDT e PSDB vêm em segundo e terceiro lugar como os partidos que possuem, relativamente, mais deputados com mestrado/doutorado completo. No entanto, é entre os petistas que se encontra a maior porcentagem de parlamentares que não terminaram o segundo grau (9\%), bem mais do que nos outros partidos. O PT singularizase, portanto, por ter, num polo, a maior proporção de deputados com a mais baixa escolaridade e, noutro, com a mais alta. A discrepância na formação dos parlamentares petistas pode ser explicada pela forte presença, por um lado, de professores em sua bancada (mais estimulados profissionalmente a fazer uma pós-graduação) e, por outro, de trabalhadores manuais qualificados e de lavradores de baixa escolaridade.

\footnotetext{
1 Porcentagem calculada excluindo os parlamentares para os quais não conseguimos
} informação (dezessete casos).
O PPB, em que se encontra a maior proporção de empresários e de deputados com patrimônio elevado, é o segundo partido, após o PT, em porcentagem de parlamentares que não têm curso superior. Com a exceção do PT, a bancada pepebista possui um nível de escolaridade um pouco mais baixo do que a dos demais partidos.

Entre os deputados do PT a situação é oposta à do PPB: alto capital cultural de boa parte de seus membros que têm curso de pós-graduação, numa bancada em que os níveis gerais de escolaridade e de patrimônio são os mais baixos entre os seis partidos. No PPB, convivem uma proporção elevada de parlamentares de renda elevada e outra de escolaridade baixa em comparação com outras bancadas (PT excluído)

Tabela 8

Instrução por partido

\begin{tabular}{|c|c|c|c|c|c|c|c|}
\hline \multirow{2}{*}{ Instrução } & \multicolumn{6}{|c|}{ Partidos } & \multirow{2}{*}{$\begin{array}{c}\text { Total da } \\
\text { CD }\end{array}$} \\
\hline & PPB & PFL & PMD & PSDB & PDT & PT & \\
\hline $\begin{array}{l}1^{\circ} \text { grau incompleto a } \\
2^{\mathrm{o}} \text { incompleto }\end{array}$ & 1,9 & 2,9 & 2,6 & 2,1 & 4,2 & 8,9 & 3,6 \\
\hline $2^{\circ}$ grau completo & 11,1 & 5,8 & 6,3 & 5,2 & 4,2 & 3,6 & 6,5 \\
\hline Superior incompleto & 3,7 & 5,8 & 7,5 & 8,2 & 0 & 14,3 & 7,7 \\
\hline Superior completo & 75,9 & 80,6 & 73,6 & 73,2 & 79,2 & 58,9 & 73,3 \\
\hline Mestrado/doutorado & 7,4 & 4,9 & 10,0 & 11,3 & 12,4 & 14,3 & 8,9 \\
\hline $\mathrm{N}$ & 54 & 103 & 80 & 97 & 24 & 56 & 495 \\
\hline
\end{tabular}

Obs.: Estão excluídos da base de cálculo os parlamentares sobre os quais não constavam informações sobre a escolaridade.

As variações nos níveis de escolaridade das bancadas dos partidos relacionam-se com as atividades profissionais/ocupacionais que os parlamentares exerciam antes de entrarem na vida política, atividades que estão, por sua vez, relacionadas ao tipo de diploma (Direito, Medicina, Engenharia, na maioria dos casos). Ao que parece, a pós-graduação deve ter sido menos importante nas ocupações anteriores dos membros das bancadas do PPB e do PFL (em que a proporção de empresários e altos funcionários do governo federal é maior) do que nos partidos de esquerda e de centro que têm, proporcionalmente, mais ex-professores nas suas bancadas e que necessitavam do diploma de pós-graduação para a ascensão na profissão. 
Chamam à atenção, ainda, as discrepâncias entre o PPB e o PT. A proporção de parlamentares do PPB que não tem curso superior (20\%) é a mais alta entre todas as bancadas, superando a do PT que vem em segundo lugar (17\%) (tabela 9). No entanto, quando se compara a proporção dos que iniciaram um curso superior, mas não a terminaram, encontramos apenas $3 \%$ de casos entre os parlamentares do PPB ao passo que, entre os petistas, a proporção sobe para 14\%. Uma hipótese, aqui, seria a de que, nos grupos de renda mais elevada, os que entram para uma universidade, ou algum instituto de ensino superior, tendem a terminar os estudos enquanto, de outra parte, muitos dos que se dedicam (ou se dedicaram) a uma atividade de tipo empresarial não se interessaram pelo diploma de nível superior. Do lado petista, a explicação poderia estar na maior proporção de tentativas frustradas de obtenção de um diploma por pessoas de renda baixa. Provavelmente, a alta incidência, entre os petistas, de parlamentares que entraram, mas não terminaram um curso universitário se explicaria em função do tipo de carreira política que distinguiria os políticos dos dois partidos: idade de início da atividade política; impossibilidade de arcar com os custos dos estudos etc.

Em todos os seis partidos, a porcentagem de formados em Direito é bastante superior à dos que possuem outros diplomas de grau superior. Dois partidos desviam-se ligeiramente dessa norma: em primeiro lugar o PDT, com um "excesso" de bacharéis em Direito (52\%), cerca de $20 \%$ a mais do que os outros partidos; e, em segundo, o PT, com um "excesso" de parlamentares com formação em algum curso de ciências humanas $(20 \%)$, mais do que o dobro da bancada do PPB (8\%) e do PFL (6\%), o que reforça a ideia de algum tipo de associação entre "formação humanística" e disposições políticas mais à esquerda em contraposição a alguma formação mais técnica, como Engenharia, que teria correlação mais forte com preferências políticas comparativamente mais à direita (tabela 9). A proporção de formados em Engenharia no PPB e no PFL é cerca do dobro da encontrada no PT, no PDT e no PSDB.
Tabela 9

Formação universitária por partido

\begin{tabular}{|c|c|c|c|c|c|c|c|}
\hline \multirow{2}{*}{ Diploma } & \multicolumn{7}{|c|}{ Partidos } \\
\hline & PPB & PFL & PMDB & PSDB & PDT & PT & $\mathrm{CD}$ \\
\hline Direito & 31,7 & 35,2 & 30,3 & 31,3 & 52,0 & 20,3 & 31,0 \\
\hline Medicina & 6,7 & 11,4 & 15,2 & 14,5 & 16,0 & 11,9 & 13,1 \\
\hline Engenharia & 15,0 & 16,2 & 14,1 & 7,2 & 8,0 & 8,5 & 11,7 \\
\hline Humanas & 8,3 & 5,7 & 13,1 & 9,6 & 16,0 & 20,3 & 10,5 \\
\hline Economia & 18,3 & 20,0 & 10,1 & 19,3 & 4,0 & 10,2 & 14,8 \\
\hline Exatas & 3,3 & 3,8 & 9,1 & 6,0 & 0 & 1,7 & 5,8 \\
\hline $\begin{array}{l}\text { Outro } \\
\text { curso }\end{array}$ & 5,0 & 2,9 & 3,0 & 1,2 & 8,0 & 8,5 & 4,1 \\
\hline Incompleto & 3,3 & 5,7 & 8,1 & 7,2 & 0 & 13,6 & 7,4 \\
\hline Não tem & 20,0 & 10,5 & 8,1 & 12,0 & 8,0 & 16,9 & 12,8 \\
\hline $\mathrm{N}$ & 60 & 105 & 99 & 83 & 25 & 59 & 513 \\
\hline
\end{tabular}

Uma avaliação sociológica geral

Como vimos nas tabelas anteriores, em todas as bancadas há uma categoria socio-ocupacional predominante, mas nenhuma bancada está composta só por parlamentares vindos dessa categoria. Os dados das tabelas e dos quadros anteriores mostraram que os partidos têm celeiros diferentes (mas preferenciais) de recrutamento. $\mathrm{O}$ fato não elimina a existência de uma ordem de importância dos variados setores socio-ocupacionais dentro das instâncias dirigentes partidárias, ordem definida pelo espaço que esses setores ocupam nas bancadas de cada legenda. No final, a presença, ou a ausência, de certos setores sociais constitui um elemento indicativo do perfil partidário.

A existência de mais de um segmento social nas bancadas possibilita combinações variadas de categorias socioeconômicas. Em algumas legendas, uma só categoria é amplamente hegemônica; em outras, existe uma divisão de espaço relativamente mais equilibrada dentro da bancada, resultante da presença de outras categorias com as quais a categoria predominante pode conviver. Certamente, em princípio, a ampliação da gama de interesses sociais no interior dos partidos aumenta o arco de 
representatividade da organização partidária e suas chances de êxito eleitoral. Mas algumas combinações são incompatíveis em razão de interesses, valores e objetivos estruturalmente opostos. Segmentos importantes de empresários podem "combinar" sem muitos problemas com profissionais liberais e com membros da alta administração pública, mas não com segmentos extraídos das classes assalariadas.

Em contraposição, intelectuais, professores e profissionais liberais, por exemplo, podem "combinar" (e frequentemente "combinam") com lideranças sindicais originadas de classes trabalhadoras. Nesse sentido, é significativo que a pesquisa não tenha encontrado, numa mesma bancada partidária, parcelas importantes de empresários, professores e trabalhadores.

É justamente a combinação singular dessas categorias que individualizam os partidos e os fazem diferentes entre si. Considerando seu espaço no interior das bancadas, têm-se combinações que revelam a composição social dominante dentro da representação parlamentar e, com alta probabilidade, nos órgãos máximos dos partidos. O conceito de composição social dominante, semanticamente, inspira-se no de "coalizão dominante" de Ângelo Panebianco (Panebianco, 1988), no qual, porém, a coalizão dominante designa os grupos que, pertencendo ou não ao partido, controlam suas "zonas de incerteza" mais vitais, como as finanças partidárias, o sistema de comunicação, as relações com o meio externo etc.

No caso desta pesquisa, usamos o termo composição social dominante para definir a combinação de categorias socioeconômicas majoritárias no interior da representação parlamentar que têm papel decisivo na determinação da ideologia, do programa, das metas e das estratégias dos partidos.

Em algumas das legendas examinadas, apenas uma categoria socioocupacional - pelo espaço que ocupa na bancada — pode ser definida como dominante no interior da composição. O perfil ideológico do partido é, então, mais nítido e homogêneo. Em outras legendas há mais equilíbrio entre as categorias que formam as respectivas bancadas, resultando daí opções políticas menos nítidas, conflitos internos mais fortes, menor disciplina partidária e um perfil ideológico mais difuso. De modo mais geral, entendemos que é a composição social dominante que imprime a marca do partido, que leva as pessoas, com maior ou menor grau de consciência, a se identificar com essa ou aquela legenda e a abominar outras.
A partir do espaço distinto ocupado pelos segmentos socioeconômicos nas bancadas, tentaremos caracterizar socialmente os seis partidos. Apesar dos riscos do esquematismo sociologizante, abdicar dessa tentativa significaria também abdicar da possibilidade de os partidos serem caracterizados socialmente, seja em razão de uma impossibilidade metodológica (obtenção de informações seguras, por exemplo), seja porque não existiriam diferenças socio-ocupacionais significativas entre os partidos nas sociedades pós-industriais. A classe política teria alcançado grande autonomia ante os grupos sociais. A primeira suposição reduziria excessivamente o potencial analítico da sociologia política. A segunda implicaria que as diferenças nas orientações políticas dos partidos não teriam vinculações com as categorias profissionais e ocupacionais que neles têm posições de comando.

Essa posição significaria, na realidade, entender que as diferenças sociais observáveis e observadas entre os partidos se deveriam ao acaso das opções individuais, distribuídas aleatoriamente, sem nenhum tipo de vinculação com os vários meios externos ao sistema partidário. No limite, essa posição leva à impossibilidade de uma sociologia da política. Mas as observações, quase de senso comum, da vida dos partidos, de suas lideranças, dos meios de onde vieram, indicam que os partidos não são programática e politicamente iguais. Por isso mesmo, tendem a atrair para suas fileiras e a ganhar o voto de pessoas socialmente diferentes. Se assim é, cabe tentar entendê-los sociologicamente, o que não necessariamente obriga-nos a negar toda autonomia para as variadas facções da classe política. É o que tentaremos fazer nas linhas seguintes.

$P P B$ - Esse partido tem um perfil social relativamente homogêneo: os empresários constituem a categoria amplamente predominante, $68 \%$ dos membros da bancada, a mais alta entre todos os partidos. As profissões liberais tradicionais estão fracamente representadas: somente $18 \%$, a mais baixa na CD. Nesse grupo, há seis casos de deputados que, juntamente com as atividades empresariais, tinham outra profissão. Se aceitarmos que a ocupação empresarial tende a ser dominante, a presença de outras profissões/ocupações não contribui significativamente para fazer a bancada do PPB mais heterogênea do ponto de vista socio-ocupacional. Sem contrapartida relevante de outros segmentos sociais, o PPB tem uma composição social em que os deputados que tinham (ou têm) atividades 
ligadas aos negócios e t o mercado no setor urbano ou rural são totalmente dominantes. O formato dessa composição coloca o PPB numa situação polar à do PT: entre os pepebistas, o segmento dominante é o dos empresários, ligados mais ao setor de mercado do que ao estatal; entre os petistas, a composição social dominante inclui professores, trabalhadores e empregados. Se aos aspectos socio-ocupacionais acrescentarmos as características do perfil educacional das duas bancadas, a polaridade entre PPB e PT fica ainda mais saliente, o que ajuda a explicar o antagonismo político-ideológico entre os dois partidos.

PFL - A composição social dominante desse partido é também empresarial, quase igual à do PPB $(68 \%$ e $61 \%$ de empresários, respectivamente). Mas o PFL recrutou bem mais no setor governamental do que o PPB (22\% contra 13\%), e mais do que os outros partidos. A discrepância é mais acentuada quando se focaliza apenas o alto funcionalismo federal. A distribuição ocupacional dos membros da bancada peefelista sugere um partido com fortes raízes no aparelho estatal, notadamente no do governo federal. A composição social dominante do PFL é formada por um setor empresarial acompanhado por uma proporção menor, mas importante, de profissionais liberais e de membros da alta burocracia federal e estadual. Para uma melhor avaliação da composição dessa legenda, cumpre acrescentar que o PFL é o partido com a maior proporção de empresários que são também profissionais liberais (8\%) e altos funcionários $(8 \%)$.

Assim como no PPB, e considerando as declarações de bens, tem-se uma legenda relativamente homogênea, com a maior parte de seus integrantes nas faixas patrimoniais mais elevadas dos quais, uma boa parte, iniciou a carreira política pelos altos escalões das administrações públicas federal e estaduais.

$P M D B$ - Seu perfil socioeconômico é menos nitidamente marcado. A fração de empresários é predominante, mas não majoritária. A proporção de profissionais liberais, de profissões intelectuais e de professores é relativamente elevada, superior à do PPB e à do PFL, mas inferior à dos dois partidos de esquerda. Em contraposição, no exame da distribuição das declarações de bens por partido, a proporção de parlamentares peemedebistas na faixa de alto patrimônio vem em terceiro lugar (16\%), mas muito distante do PFL (29\%) e do PPB (22\%). Relembremos, por fim, para uma avaliação mais adequada da composição social dominante do PMDB, que não há, na sua bancada, deputados recrutados entre operários ou empregados do setor de serviços, para não falarmos de lavradores.

Algumas monografias sobre o PMDB (Kinzo, 1988; Melhem, 1998) indicam que as posições relevantes na organização partidária peemedebista são controladas por um setor empresarial de formação mais recente, sem a tradição de mando e de participação na política nacional, como no caso do PFL. Sendo assim, provavelmente a fração empresarial na bancada do PMDB - majoritária, mas sem maioria absoluta - tenha mais dificuldade para se impor e para definir a orientação partidária ainda que possa manter considerável poder de veto. Essa distribuição de forças entre as categorias socio-ocupacionais sugere, em comparação com outros partidos, uma organização com mais dificuldade para a definição de interesses, manutenção da coesão ideológica, da disciplina interna e com mais conflitos entre suas facções. Talvez por essa razão as pesquisas sobre disciplina partidária na CD (citadas no capítulo 1) classifiquem o PMDB como o partido de bancada mais indisciplinada.

$P S D B$ - A composição social dominante desse partido é dada pela união de uma intelectualidade de renda elevada com setores empresariais, minoritários, mas importantes. As parcelas da intelligentsia que, nesses últimos anos, ascenderam política, econômica e socialmente - quer dizer, que conseguiram uma taxa elevada de conversão de capital cultural em capital econômico - estão unidas a uma fração das classes empresariais ilustradas. Pelos dados da pesquisa, o setor empresarial no PSDB é preponderantemente urbano. A participação de parlamentares que eram (ou são) empresários rurais é muito pequena, inferior à de todos os outros partidos, exceto o PT. A fração intelectual é predominante e parece dar o tom ao partido. Essa caracterização fundamenta-se empiricamente no peso que têm, na sua bancada, as profissões intelectuais, os altos funcionários da União, os profissionais liberais e os professores.

A face intelectual marcou o PSDB desde o seu início. Como notaram Jales Ramos Marques e David Verge Fleischer, ao examinarem a composição social dos quarenta deputados e oito senadores tucanos no período final da Assembleia Nacional Constituinte (ANC), havia no grupo dos "pais fundadores" do PSDB poucos empresários rurais e funcionários públicos e "muitos advogados e juízes, e ainda um pouco mais de 
profissionais da saúde, educação, jornalismo do que a média da ANC" (Marques \& Fleischer, 1999, p. 105). Então (junho de 1988), a proporção de advogados e juízes, entre os primeiros tucanos, era de $30 \%$ contra a média de 9\% da ANC. Os parlamentares formados em Economia continuaram ocupando um bom espaço na representação do PSDB. Na CD eleita em 1990, havia 8\% de economistas, porcentagem muito superior à encontrada nos demais partidos e apenas superada pela existente no PDT (19\%). Na de 1994, os economistas eram 11,3\%, mais do dobro da existente em outras legendas e no total da CD $(4,7 \%)$.

Outro traço a singularizar o partido reside na proporção de seus deputados formados em ciências humanas: $14 \%$ contra, por exemplo, $7 \%$ do PFL e 5\% do PDS. Os tucanos, na legislatura eleita em 1990, vale lembrar, eram superados apenas pelo PT, com $17 \%$. Na legislatura que saiu da eleição de 1994 , a bancada tucana possuía $8,1 \%$ de formados em ciências humanas, porcentagem superada apenas pela do PT $(16,3 \%)$ (Marques \& Fleischer, 1999, pp. 106 e 107). Na atual, como vimos, a proporção de diplomados em alguma disciplina de ciências humanas é de $13 \%$, superada apenas pela do PT (20\%) e pela do PDT (16\%).

PDT - Trata-se de um partido com poucos empresários, poucos deputados recrutados do setor público e nenhum parlamentar originário das classes trabalhadoras. As profissões liberais tradicionais são majoritárias, com grande peso dos advogados. A proporção de parlamentares vindos do setor produtivo e de outras camadas relevantes da sociedade brasileira é pequena. A composição social dominante corresponde a um grupo majoritário de profissionais liberais seguido de um grupo pequeno de empresários urbanos.

$P T$ - A fração da intelectualidade (entendida num sentido amplo) também é predominante na bancada petista (com mais professores do que o PSDB), mas esse grupo aparece junto a uma fração importante, mas minoritária de membros das classes populares (trabalhadores, empregados não manuais e lavradores). Além disso, praticamente não há empresários entre os seus integrantes, como na representação tucana. A composição social dominante estaria, pois, integrada pela intelligentsia da classe média burocrática e por lideranças operárias que, com a redemocratização, conseguiram entrar para a classe política por intermédio dos grandes sindicatos (geralmente metalúrgicos) e empregados não manuais (geralmente bancários). Além disso, se o patrimônio serve de indicação, a intelligentsia petista, em comparação com a tucana, veio de camadas mais baixas, das classes médias relativamente cultas, mas de baixo patrimônio e provavelmente também de baixa renda. ${ }^{2}$ Trata-se, portanto, de grupos com certa incongruência de status (antes da ascensão para a classe política), o que explicaria a preferência por um partido de esquerda e a aliança com setores das classes trabalhadoras em ascensão. É uma hipótese que vem do exame conjunto das ocupações/profissões, dos níveis de patrimônio e da formação educacional da maioria da bancada do PT e que, talvez, possa ser rejeitada mediante um exame mais pormenorizado da carreira individual e da origem familiar dos seus integrantes. ${ }^{3}$

\section{Conclusão}

Os dados relativos à composição socio-ocupacional, à dimensão patrimonial, aos níveis de escolaridade e à formação universitária das bancadas mostram que os seis partidos brasileiros se diferenciam não apenas quanto à ideologia (a face mais visível da vida dos partidos), mas também quanto aos segmentos sociais neles representados. Essa face sociológica permite dizer - sem ignorar a dinâmica interna das disputas parlamentares e dos interesses individuais dos políticos - que os conflitos partidários e as lutas políticas na $\mathrm{CD}$ têm um coeficiente elevado de correspondência com as composições sociais dos partidos.

Não há aqui nenhuma novidade, mas, no caso brasileiro, aceitar a suposição acima significa também atribuir ao nosso sistema partidário alguma consistência em termos de sua representatividade, mesmo que se

${ }^{2}$ Como vimos, há muitos professores na bancada petista, quer dizer, deputados com escolaridade relativamente alta. A grande maioria tem baixo patrimônio. Pelos dados de doze declarações de bens de vinte ex-docentes da bancada petista, onze deles estão na faixa de baixo patrimônio e um está na de médio-baixo. Nenhum, portanto, está nas faixas patrimoniais superiores.

${ }^{3}$ Como vimos, PT e PSDB têm, nas suas bancadas, parte importante vinda de camadas cultas da população. Nesse ponto, uma diferença entre os dois partidos vem do fato de que os deputados petistas com alto nível educacional compartilham lugar na bancada com colegas de baixa escolaridade. Já a intelectualidade tucana convive com um grupo importante de empresários (ou ex-empresários) de alta escolaridade. É possível, pois, que na competição interna por postos importantes na bancada e na $\mathrm{CD}$, a situação da intelligentsia petista seja mais confortável do que a dos tucanos. 
possa ter uma avaliação negativa de seu funcionamento (e de grande parte da classe política brasileira).

Nessa colocação, o risco do esquematismo sociológico é forte. Os partidos modernos, nas democracias de massa - estamos cansados de saber —, não são meros reflexos de classes sociais, como aparece em muitas análises marxistas, entre eles Gramsci. ${ }^{4}$ A composição social das bancadas não é a única variável a ser levada em conta no estudo das orientações partidárias. Uma análise mais sofisticada necessitaria considerar diferenças regionais, valores e crenças que não são diretamente dedutíveis das variadas formas de vinculação com o sistema social, além naturalmente das ambições individuais de ascensão que podem levar os políticos a orientações e comportamentos descolados dos seus meios de origem. A consideração desses aspectos, entretanto, ultrapassa de longe os objetivos mais modestos deste trabalho que visou apresentar alguns dados e jogar algumas hipóteses para a discussão.

\section{AS PROFISSÕES PARA A POLÍTICA}

Este capítulo traz um quadro da composição do Legislativo dos principais países democráticos. Em todos eles, o recrutamento para a classe política é efetuado de um número pequeno de profissões e ocupações: empresários, advogados, professores, funcionários públicos e sindicalistas. A proporção dessas categorias nos parlamentos ocidentais varia com a votação dos partidos. A participação de lavradores e trabalhadores agrícolas é baixa em toda parte. A de operários manuais, atualmente, é fraca, inclusive em democracias em que ela já foi elevada e em que a esquerda está no poder.

A relação entre as tendências político-ideológicas dos seis partidos e as ocupações/profissões predominantes em suas bancadas não é seguramente um achado surpreendente. Poucos autores põem em dúvida algum tipo de relação entre os partidos e determinadas camadas sociais, grupos étnicos e linguísticos, religiões, faixas etárias, áreas geográficas e outras divisões que resultam em clivagens programático-ideológicas, políticas e partidárias. De nossa parte, ao acentuarmos as diferenças de espaço que as categorias socioprofissionais ocupam nos diferentes partidos não queremos trazer junto a afirmação de que as lideranças partidárias são "representantes" de segmentos sociais ou ocupacionais, de classes, de grupos de status ou algo parecido. Nas democracias de massa, uma orientação político-eleitoral "exclusivista" (no sentido de mirar apenas para poucos setores sociais) pode levar partidos e políticos a perder eleitores, fato que reduziria as suas chances de alcançar ou permanecer no poder. Hoje, esse comportamento eleitoralmente reducionista não é habitual na classe política. Para se ter êxito eleitoral, é preciso adaptar-se às tendências dominantes no eleitorado, às vezes contrariar seus próprios "interesses de classe" e os de certos grupos de pressão amigos. Afinal, pelo menos em certa medida, pode-se concordar com Downs quando afirma: "Os partidos formulam políticas para ganhar eleições e não ganham eleições para formular políticas" (Downs, 1957, p. 28).

Mais do que nunca, a disputa nas democracias de massa obriga os políticos a ampliar suas mensagens para sensibilizar interesses societais mais amplos do que os existentes nas cúpulas partidárias, funcionando, de algum modo, como catch-all parties. Mas esse ponto não será discutido aqui porque se refere mais precisamente às estratégias de maximização de
${ }^{4}$ Gramsci entende que cada partido é a expressão "de um grupo social e de um só grupo partidos (Gramsci, 1968) 
votos dos partidos. A ele fizemos menção apenas para eliminar a ideia de que, ao trabalharmos com o tema das vinculações entre composição social, orientação político-programática e ideologia, estivéssemos sustentando a tese de que as categorias ocupacionais predominantes nas suas cúpulas constituiriam a única variável a afetar a conduta partidária.

Mais promissor para o entendimento dos meandros tortuosos da luta pelo poder nas democracias de massa (que depende da quantidade de votos recebidos e envolve, pois, a conquista de eleitores) é partir da existência de uma complexa rede de interações que se efetuam principalmente entre: 1) interesses (e valores) específicos dos políticos na qualidade de membros da classe política e 2) os das categorias socioeconômicas dominantes no interior de cada partido. No primeiro caso, o objetivo principal é de continuar, e se possível ascender, no interior do sistema de poder, aspecto que pode ser denominado "ambição política". No segundo caso, os políticos necessitam do apoio de segmentos específicos (regionais, econômicos, associativos, institucionais, religiosos, étnicos, clientelísticos etc.) que os apoiam e que são habitualmente designados como as "bases" que os políticos precisam "escutar" e com as quais precisam manter contatos com certa frequência.

São os níveis superiores desses segmentos - em caso de vitória dos respectivos partidos, numa complexa e hierárquica rede distributiva preferencial - que irão usufruir dos benefícios seletivos que vêm da conquista de parcelas do aparelho governamental em disputa e que constituem os prêmios que os vencedores auferem (distribuição diferenciada de cargos públicos aos correligionários, amigos e parentes, informações privilegiadas, favorecimento em concorrências e, às vezes, apropriação e desvio indébito de recursos públicos).

Ao contrário do que acontece nas eleições para cargos executivos, na luta por postos nos legislativos, os candidatos têm maior margem de autonomia em suas propostas políticas e na defesa de interesses corporativos, associativos e setoriais que podem representar abertamente. Em eleições proporcionais, de escolha personalizada dos candidatos, como as brasileiras, políticos podem eleger-se defendendo interesses de segmentos específicos da sociedade dos quais podem mesmo transformar-se em porta-vozes nos órgãos legislativos. E ao contrário do que acontece em disputas majoritárias, em que as probabilidades de vitória aumentam com a ampliação dos espaços de captação de votos, nas disputas proporcionais, a delimitação das bases de apoio pode significar precisamente a chance de permanecer na classe política na medida em que permite a conservação de um eleitorado fiel.

À medida, porém, que se eleva o patamar da disputa, como sabem muito bem os políticos e os especialistas de marketing, aumenta a necessidade de conseguir votos em camadas e setores mais amplos do eleitorado. Faz-se necessário, pois, alargar as mensagens e promessas a fim de atender expectativas mais variadas e segmentadas. Apesar disso, a ampliação do campo de captação de adeptos e de votos não exclui preferências relativas por linhas políticas e propostas de governo que, justamente, individualizam os partidos e os fazem diferentes uns dos outros, mesmo nas democracias de massa. Essas diferenças interpartidárias não vêm do eleitorado, mas dos grupos e segmentos sociais que controlam os escalões superiores das organizações partidárias, aí incluídas as suas representações parlamentares.

\section{As fontes de abastecimento da classe política}

A análise socio-ocupacional das bancadas dos partidos poderia também ser feita do prisma do recrutamento para a classe política. Seus membros são, em toda parte, preferencialmente extraídos de um número bastante pequeno de segmentos profissionais e ocupacionais, como vimos inicialmente. Trata-se de pessoas que desenvolveram, pela formação educacional ou pela tradição familiar, "o gosto pela política"; pessoas que geralmente estão próximas do sistema de poder por conexões familiares e/ou sociais ou, ainda, que ocupam posições importantes em instituições que necessitam manter algum tipo de atividade de pressão sobre os poderes públicos (associações empresariais, sindicatos de trabalhadores, ONGs e outros tipos de associações). A CD que analisamos está longe de ser uma exceção na comparação com outros países. A preponderância, em sua composição, de alguns poucos segmentos ocupacionais e profissionais não resulta de nosso passado elitista, nem das marcas autoritárias e das desigualdades sociais do Brasil contemporâneo. 
Em toda parte, algumas profissões/ocupações - talking professions, chattering classes - estimulam aptidões e preparam para a política. ${ }^{1}$ Pipa Norris cita, entre essas profissões, os altos funcionários, os professores, os jornalistas e os advogados, os quais juntamente com empresários compõem o grosso da representação parlamentar na maioria dos países (Norris, 1996). Mattei Dogan, por sua vez, inclui entre as profissões du verbe et de la plume os sindicalistas (Dogan, 1999, p. 174).

Essas profissões e ocupações são as que aperfeiçoam as habilidades de expressão, de convencimento, de sedução, de argumentação e de aperfeiçoamento da arte oratória, instrumento essencial para conquistar adeptos e assegurar posição de liderança entre os próprios integrantes da classe política. Não há futuro para o político profissional sem o domínio da oratória. ${ }^{2}$ Apesar dos dotes individuais sempre necessários, algumas profissões qualificam melhor para os debates parlamentares e públicos. Esse é particularmente o caso dos bacharéis em Direito, em especial na fase de sistemas políticos com participação eleitoral limitada.

\section{Os advogados e os magistrados}

A magistratura foi um dos principais celeiros de recrutamento para a classe política na maioria dos países ocidentais. ${ }^{3} \mathrm{Na}$ III República francesa, por exemplo, de cada cinco deputados, dois eram advogados (Dogan, 1999,

\footnotetext{
${ }^{1}$ Em todos os países, em famílias de tradição de participação política, a escolha da formação educacional pode ser já resultante da intenção de preparar os jovens para o recebimento da herança política do clã e garantir a continuidade da família no sistema de poder. (Um interessante estudo sobre continuísmo político regional, atravessando gerações, encontra-se em dois artigos de Letícia Bicalho Canêdo. A autora toma o caso da própria família no interior de Minas Gerais, por meio do qual se vê a reprodução da tradição política do clã. Cf. Canêdo, 1998 e 1999.)

${ }^{2}$ Era na oratória que Michels localizava a fonte da dominação dos líderes nos países democráticos: "O fundamento da supremacia dos chefes [...] é a virtude oratória. Não há multidão que escape da força estética e emotiva da palavra [...] No regime democrático, os chefes natos são oradores e jornalistas" (Michels, 1924, pp. 71-72). A afirmação pode ser estendida para todos os grandes chefes políticos, em especial para as lideranças populistas.

3 No Brasil, como mostra José Murilo de Carvalho, no período imperial, além da magistratura, houve também importante participação de militares, padres e fazendeiros. Mas, em todo o período, houve mudanças na importância desses setores. A dos padres, por exemplo, declinou a partir de 1886, enquanto aumentou a dos bacharéis em Direito (Carvalho, 1980)
}

p. 177); nos EUA eram 35\% (1990); no Reino Unido, 13\% (1992); em Portugal, 21\% (1987); na Grécia, 38\% (1990); na Suíça, 17\% (1991); no Japão e França, $6 \%$ (1986 e 1990); no Canadá, 19\% (1988) e na Austrália, $11 \%$ (1987).

A importância de uma categoria profissional na política tende a variar segundo os resultados de cada eleição. No caso da França, 1986 foi um ano particularmente ruim para advogados e magistrados. Nesse ano, na Assembleia Nacional havia somente 38 advogados num total de 577 parlamentares. Mas, em 1993, o número subiu para 56 (9,7\%) (Dogan, 1999 , p. 197). De modo geral, a presença relativa de advogados tendeu a declinar na maioria dos países à medida que ocorria a universalização do sufrágio e a ascensão de lideranças recrutadas de outros meios, entre os quais a docência e o sindicalismo.

\section{Professores}

Na Itália, na legislatura de 1987-1992, 20\% dos deputados eram professores do ensino secundário e do superior, contra $12 \%$ de advogados e notários. Na de 1992-1994, os professores (de todos os níveis de ensino) chegavam a $19 \%$ contra $11 \%$ de advogados (Briquet, 1999, p. 76). Na França, em 1981, sob o governo socialista de Mitterand, de cada três deputados um era professor. "A expressão 'República dos Professores' não era, portanto, exagerada" (Dogan, 1999, p. 180). Em 1981, os professores da escola elementar francesa eram a categoria mais representada entre os comunistas: $30,4 \%$ contra 27,3\% dos candidatos vindos das classes trabalhadoras (Thiébault, 1988, p. 9).

Na França, na IV República, a maioria dos deputados que haviam sido professores de liceus era de tendência socialista ou comunista enquanto a maioria dos docentes de universidade tendia para o MRP (Mouvement Républican Populaire - Movimento Republicano Popular), para a ala radical ou para a moderada desse partido. No começo do século, os professores do ensino público de primeiro grau dividiam-se entre o Partido Radical e o Partido Socialista, e em meados do século XX, entre esse último e o Partido Comunista (Dogan, 1999, p. 79).

Uma análise mais detalhada da categoria docente na vida parlamentar e política pressuporia levar em conta as disciplinas e os tipos de instituições 
de ensino para detectar as possíveis diferenças de orientação partidária da elite acadêmica e as do baixo clero universitário, atentando para as possíveis diferenças de inclinação política dos docentes das escolas públicas e das escolas privadas. Ocorre que, na bibliografia internacional, nem sempre essas distinções são feitas. Outras vezes, os dados sobre professores dos vários níveis aparecem desagregados, dificultando comparações internacionais.

Considerando apenas o caso da França, em que a diferenciação entre os níveis de ensino aparece nas fontes que consultamos, percebe-se o fenômeno do aumento da proporção de professores do ensino elementar nos órgãos de representação sem que houvesse declínio da presença do alto clero universitário, o que redundou no incremento geral da participação dos professores. Uma explicação para o fato talvez resida no aumento do ativismo sindical dos docentes. A hipótese aqui é a de que os professores do ensino básico, ao mesmo tempo, são mais numerosos e necessitam contar com o apoio corporativo e sindical para serem eleitos. Os grandes nomes do mundo acadêmico não só têm uma base eleitoral corporativa mais estreita como provavelmente dispõem de outros trunfos e apoios para entrar na carreira política.

Essas observações vêm do exame de dados sobre a presença dos instituteurs na Assembleia Nacional Francesa. Até 1893, nunca foram mais do que três (em números absolutos). Nesse mesmo ano, os deputados vindos do ensino superior e do médio chegavam a 33. Na IV República, porém, entre 1945 e 1958, 66 mestres do ensino básico e 99 do magistério superior foram eleitos para a Assembleia Nacional. Nos anos seguintes, houve redução na representação parlamentar dos professores dos níveis inferiores; em 1986, 149 professores do ensino superior e médio foram eleitos para a Assembleia Nacional, contra 66 do ensino elementar. Em 1993, havia 87 parlamentares do primeiro grupo em contraposição a somente quinze instituteurs (Dogan, 1999, p. 197).

\section{Funcionários públicos}

Outra categoria que cresceu nos parlamentos foi a dos funcionários e membros da administração pública. Na Alemanha de Bonn, $40 \%$ dos membros do Bundestag eram funcionários. Na França, os altos funcionários da Assembleia Nacional francesa passaram de 4\% em 1946 para $18 \%$ em 1993 (Dogan, 1999, p. 195). O espaço ocupado pelos funcionários, no entanto, exibe muita variação quando se comparam os legislativos nacionais. Por volta de 1990, os membros da burocracia pública compreendiam 33\% dos deputados da Dieta japonesa (1990) e 20\% da Assembleia Nacional francesa (1986) e 11\% da Câmara dos Comuns do Reino Unido (1992). Mas eram somente 5\% do Parlamento de Israel (1992) (Inter-Parliamentary Union, 1990-1992, apud Norris, 1996 pp. 188-189).

\section{Os empresários e homens de negócios}

Os homens de negócios, executivos, comerciantes e empresários de modo geral, ${ }^{4}$ por sua vez, tendem a ter uma presença forte na Câmara Baixa da maioria dos países, inferior apenas à dos advogados, mas superior à dos professores (de acordo com a fonte citada). No entanto, com exceção dos EUA, raramente compõem muito mais do que $20 \%$ dos parlamentares. A proporção oscila significativamente segundo os países e, provavelmente, segundo as eleições e os partidos que vão ao poder.

Como seria de se esperar, industriais e comerciantes estão em maior número nos partidos de direita e de centro (cf. Gatti, 1999; Briquet, 1999; Norris, 1996; Loewenberg \& Patterson, 1979, cap. 3: "Membership"). Exceto o caso dos Estados Unidos, na maioria das democracias desenvolvidas, a proporção de homens de negócios nas Câmaras Baixas oscila bastante. No total de deputados, os empresários seriam 6\% na França (em 1986) e no Japão (em 1990); 30\% nos EUA (em 1990); $22 \%$ na Austrália e no Canadá (em 1987 e 1988); 13\% no Japão (em 1990); $12 \%$ na Suíça (em 1991); $20 \%$ na Nova Zelândia (em 1990) e 24\% no Reino Unido (em 1992) (Inter-Parliamentary Union, apud Norris, 1996, p. 188-189).

Dados de outra fonte indicam que os empresários e os homens de negócios, na década de 1970, raramente ultrapassavam um quarto do total dos parlamentares das democracias dos países desenvolvidos (Loewenberg \& Patterson, 1979, p.70). Já salientamos que a participação relativa das profissões e dos celeiros de recrutamento da classe política tende a mudar

${ }^{4}$ Business and finances, na classificação da Inter-Parliamentary Union (apud Norris, 1996, pp. 188-189). 
com as variações dos resultados das eleições. A presença dos empresários geralmente cresce com as vitórias eleitorais dos partidos de direita. $\mathrm{Na}$ Itália, por exemplo, o êxito da coligação Polo da Liberdade (direita), nas eleições italianas de março de 1994, elevou a proporção de profissionais liberais e de empresários no parlamento italiano em detrimento dos parlamentares que vinham das funções públicas, da burocracia partidária e dos sindicalistas, dos membros de associações profissionais e culturais. $\mathrm{Na}$ legislatura de 1994, a participação dos industriais, executivos e comerciantes - que representava $5 \%$ dos deputados na legislatura de 19871992 - pulou para 16\% (Briquet, 1999, p. 259).

\section{Agricultores}

A proporção de agricultores, em toda parte, é geralmente baixa: $2 \%$ no Reino Unido; $3 \%$ na França e no Japão e, nos EUA, 4\%. A Nova Zelândia (15\%), a Suíça $(13 \%)$ e o Israel $(8 \%)$ fogem da regra (Norris, 1996, pp. 188-189).

\section{Os operários e os sindicalistas}

Desde começos do século XX, com as inevitáveis oscilações e variações segundo os países, trabalhadores industriais e sindicalistas vinham ampliando sua presença nos organismos políticos. Foi no Reino

\footnotetext{
${ }^{5}$ Esses números devem ser tomados como indicações gerais e são um pouco antigos, mas encontram reforço em outros que se referem à década de 1970 e que sugerem uma tendência relativamente consolidada, o que permite suspeitar que, nesse terreno, não houve mudanças importantes nesses últimos anos. Na década de 1970, os agricultores, na Câmara de Deputados norte-americana, eram então apenas 3\%; no Reino Unido, 4\%; na Assembleia Nacional francesa, 7\%; no Bundestag da República Federal Alemã, 6\%; na Câmara de Deputados italiana, $2 \%$. A de trabalhadores manuais, em todos esses parlamentos (e em outros que não reproduzimos para não cansar ainda mais o leitor), não foi além da média de $7 \%$, porcentagem alcançada apenas na França, na Suécia e na Finlândia (Loewenberg Patterson, 1979, p. 70). A dificuldade da comparação decorre, em parte, do fato de as categorias profissionais usadas pelos pesquisadores dos diferentes países não serem padronizadas. Em certos casos, ocupações existentes em estatísticas de alguns países não aparecem nas de outros, provavelmente porque estão agregadas a categorias mais amplas. De qualquer modo, as porcentagens que reproduzimos permitem visualizar os principais traços da representação profissional nos parlamentos de alguns países e ter algum elemento de comparação com o Brasil.
}

Unido que a participação da classe operária aconteceu mais cedo e mais significativamente. O Partido Trabalhista foi a via de ascensão das classes trabalhadoras ou, mais exatamente, das lideranças sindicais. Em 1906, todos os 29 parlamentares que foram eleitos sob os auspícios do Comitê de Representação Trabalhista, que precedeu o Labour Party, eram operários (Guttsman, 1963, p. 227). Estima-se que em 1918 eram trabalhadores 87\% da bancada do Labour (Radice, Vallance \& Willis, 1987, p. 33).

Ocorre que o Partido Trabalhista foi, em larga medida, uma criação dos sindicatos e deles (especialmente dos grandes) permaneceu dependente por longo tempo. A proporção de operários e dirigentes sindicais fora dominante na representação trabalhista, em particular porque as candidaturas para a Câmara dos Comuns eram apresentadas, apoiadas e financiadas pelas organizações sindicais. De modo mais evidente do que em outros países, o Partido Trabalhista foi o canal de participação da classe trabalhadora no sistema político, participação entendida pelos líderes sindicais como possível de ser efetuada no interior da sociedade mais capitalista da época.

Apesar disso, nem todos os candidatos sustentados pelos sindicatos eram dirigentes sindicais: alguns eram militantes de base, outros eram membros ativos do partido (recrutamento endógeno). "Mas, no geral, os sindicalistas apoiados pelos sindicatos eram de origem operária, mesmo quando eram pessoas que não mais exercessem ocupações próprias das classes trabalhadoras e possivelmente tivessem ascendido socialmente antes mesmo de entrarem para a Casa dos Comuns" (Guttsman, 1963, p. 237).

Mas a tendência favorável à ascensão parlamentar de membros das classes trabalhadoras começou a ser reinvertida a partir de meados da década de 1970. Segundo Von Beyme (1983, apud Norris, 1996, p. 186), somente $1 \%$ dos membros do Bundestag, em começos de 1980, eram operários ou artesãos assalariados. "O número dos sindicalistas no Bundestag alemão tem declinado rapidamente desde 1980. Entre 1972 e 1980, aproximadamente $16 \%$ dos parlamentares eram sindicalistas. Essa proporção baixou continuamente até menos de 3\% em 1990" (Wessels, 1997, p. 84). Em 1992, somente 10\% dos parlamentares britânicos eram trabalhadores (Norris, 1996, pp. 188-189). 
Na Dinamarca, apesar da importância do Partido Socialdemocrata na política nacional, apenas 4,5\% dos deputados do partido definiam-se como "operários". Na Austrália, no final do século XIX, a divisão entre parlamentares que tinham profissões manuais e os de não manuais era aproximadamente a mesma. Mas, por volta de 1990, apenas 6\% eram trabalhadores manuais. No Japão, onde a política raramente envolveu membros da classe operária, no período de pós-guerra, a proporção de trabalhadores girou em torno de 7,5\% (Norris, 1996).

$\mathrm{Na}$ França - que tem uma esquerda forte e que teve um partido comunista importante —, nas eleições de 1973, 1978 e 1981 para a Assembleia Nacional, pouquíssimos operários foram eleitos, inclusive pela bancada do $\mathrm{PCF}^{6}$ (Parti Communiste français - Partido Comunista francês). Embora os comunistas valorizassem os trabalhadores manuais na escolha para as listas partidárias, em nenhuma daquelas legislaturas os operários eleitos pelo PCF para a Assembleia Nacional ultrapassaram 8,1\% do total da bancada comunista. Em três delas, nenhum foi eleito. No PS, a proporção de operários era ainda mais baixa: nunca, em qualquer das referidas legislaturas, os operários representaram mais do que $4 \%$ do total da bancada e, numa delas, nenhum trabalhador conseguiu se eleger. A proporção de operários no PCF, depois de 1981, ficou sempre abaixo de $8,1 \%$ e a de classe média, depois de representar $100 \%$ da bancada comunista na eleição de 1973, oscilou entre 55,5\% (1978), 83,4\% (1981), $72,9 \%$ (1981) e 74,4\% (ainda em 1981) (Guedé \& Rozenblum, 1981, apud Collovald, 1985, p. 42).

Na Itália, na bancada comunista da Câmara de Deputados (19871992), os operários eram somente 7\%, contra $13 \%$ de advogados e notários e 18\% de professores (Briquet, 1999, pp. 276-277).

\footnotetext{
${ }^{6}$ Depois da Segunda Guerra Mundial, até começos de 1980, a votação do PCF oscilara sempre em torno de $20 \%$ do total de votos. Em novembro de 1945 , o partido havia obtido $28,6 \%$. Apesar das perdas em eleições subsequentes, em 1978 ainda chegou a 20,6\% mas, na de 1981 , baixou para $16,1 \%$ e, a partir daí, seguiu declinando (dados retirados de Mackie \&. Rose, 1991). No primeiro turno das eleições presidenciais de abril de 1995, o candidato comunista Robert Hué teve menos de $9 \%$ dos votos.
}

\section{Homogeneização da classe política}

As pesquisas não indicam apenas a redução da presença da classe operária, mas também o desaparecimento da velha aristocracia que dominava os parlamentos europeus nas fases anteriores à democracia de massa. Na Grã- Bretanha, o resultado do declínio da nobreza, por um lado, e dos mineiros, metalúrgicos e mecânicos do Partido Trabalhista, por outro, foi um Parlamento socialmente mais homogêneo (Norris \& Lovenduski 1997, p. 159). "Os membros do Parlamento são tipicamente de classe média, de meia idade, do sexo masculino e brancos" (Radice, Vallance \& Willis, 1987, p. 37).

A seleção e a ordem de apresentação dos candidatos nas listas eleitorais feitas pelos partidos é uma variável importante na composição dos órgãos de representação. Na seleção de candidatos, os socialistas tendiam a dar preferência às profissões liberais, aos empregados de escritórios e, acima de tudo, aos professores de nível superior, enquanto os comunistas tinham clara preferência pelos operários e depois pelos professores do magistério de nível secundário e elementar (Thiébault, 1988, p. 89).

O modo de seleção de candidatos afeta a composição das bancadas, pois são os partidos que selecionam os candidatos nos quais aos eleitores podem votar. Os "primeiros eleitores" são, pois, os órgãos partidários selecionadores de candidatos (locais, regionais ou nacionais). Os partidos de direita, na escolha dos candidatos, têm preferência pelos de status econômico elevado, tais como funcionários governamentais de alto nível, homens de negócios, executivos, engenheiros ou membros das profissões liberais. "O mais notável aspecto dos candidatos de direita [na França] é a alta proporção de funcionários de alto nível, especialmente antigos alunos da Escola Nacional de Administração (ENA), o que mostra a vantagem, para os membros da elite administrativa, de pertencimento a parcelas do poder" (Thiébault, 1988, p. 89). ${ }^{7}$

\footnotetext{
7 Weber tendia a acreditar que empresários, trabalhadores e médicos teriam mais dificuldades para viver para a política porque não são substituíveis em seu trabalho, como os dificuldades para viver para a política porque não são substituíveis em seu trabalho, como os
que vivem de renda. Exemplo contrário seria o do advogado. Sua importância na política ocidental, depois do surgimento dos partidos, nada teria de casual (Weber, 1964, p. 1065). Mas Weber escrevia antes da ascensão do sindicalismo como uma das fontes de poder e da máquina sindical como uma das mais poderosas instituições da sociedade capitalista
} 
Não teríamos condições de apresentar, neste trabalho, resultados mais exaustivos e atualizados da composição dos legislativos dos diversos países. Os números mostrados nas páginas anteriores, ainda que restritos a alguns países ocidentais, servem para indicar, por um lado, as principais categorias socioeconômicas das quais é geralmente recrutado o pessoal político e, por outro, as diferenças nacionais que, por sua vez, costumam variar sob a ação de múltiplos fatores. As oscilações do clima político, mais para a direita ou para a esquerda, podem conduzir ao fortalecimento ou ao enfraquecimento dos partidos nos organismos de representação e às subsequentes alterações na morfologia da classe política nacional.

Um exemplo dos efeitos de transformações na estrutura social (habitualmente as mais salientadas) foi, no passado, o crescimento dos partidos de esquerda que se apoiavam eleitoralmente sobre os trabalhadores industriais, empregados e intelectuais. Essas mudanças, conjugadas com a extensão do sufrágio para as classes populares, possibilitaram, na maioria dos países europeus, o aumento do número de operários e de assalariados no sistema de poder. Desse modo, o crescimento dos votos favoráveis aos partidos de esquerda tendeu a afetar a composição da classe política, aumentando a participação de parlamentares recrutados dos sindicatos e de outras associações de trabalhadores e empregados.

Paradoxalmente, enquanto declinava a proporção de trabalhadores, aumentava a de funcionários e dirigentes das organizações partidárias. Em outros termos: as formas de recrutamento endógeno, nesse caso, tenderam a ganhar precedência sobre as formas de recrutamento lateral, de organizações vizinhas, como os sindicatos. Na Itália, entre 1948-1958, somente um quarto dos deputados socialistas e comunistas tinha vindo do sindicalismo. Na República alemã do período anterior à reunificação, os deputados que fizeram sua carreira por meio do Partido Socialdemocrata eram mais numerosos do que os sindicalistas. Mattei Dogan considera mesmo que se poderia estabelecer uma lei sociológica válida para muitos países europeus na primeira metade do século XX: "Quando o número de

democrática. Em contrapartida, o exemplo brasileiro, da legislatura que examinamos, mostra a elevada presença de empresários e médicos. No caso, o que parece contar não é o tempo disponível para o exercício da política mas os trunfos de que dispõem certos grupos socioocupacionais para entrar na classe política. deputados comunistas e socialistas cresce, a proporção de sindicalistas entre os deputados dessas mesmas tendências diminui”" (Dogan, 1999, p. 188).

A elevação do nível de escolaridade dos parlamentares de todos os partidos, o recrutamento majoritariamente em segmentos da classe média educada e a diminuição do número de aristocratas e trabalhadores no interior dos parlamentos atuaram a favor da homogeneização social da classe política. Apesar disso, alguns dados sugerem que diferenças significativas permanecem quando se coteja a representação parlamentar de partidos de esquerda com a dos de direita.

Mas as diferenças tendem a ser de outra natureza, diversa da que opôs, no passado, trabalhadores e empresários, ou o Trabalho e o Capital. Hoje, uma clivagem significativa é a que opõe os que estão ligados ao mercado e os que estão ligados ao Estado, o que conduz a uma oposição entre setor privado e setor público e que parece pôr em confronto principalmente segmentos das classes médias com os da classe alta.

A bancada do Partido Trabalhista britânico é dominada pelos empregados do setor público: professores do ensino superior e médio, jornalistas, administradores dos governos municipais, pesquisadores políticos, funcionários dos sindicatos e de serviços de bem-estar. Em contraste, entre os conservadores, há mais empresários do setor privado, diretores de companhia, assessores financeiros e advogados [Norris \& Lovenduski, 1997, p. 166].

Na mesma direção, vale observar que, nos EUA — onde os partidos ideológicos não tiveram o mesmo papel que na Europa Ocidental e os catch-all parties logo se desenvolveram —, subsistem discrepâncias importantes na composição da representação legislativa. Nas eleições de 1992, agricultores e operários manuais representavam uma minoria entre os democratas e republicanos, respectivamente $3 \%$ e $6 \%$. Já empresários e banqueiros perfaziam $12 \%$ entre os democratas e aumentavam para $25 \%$ entre os republicanos. Mas os advogados eram em maior número entre os democratas (37\%) do que entre os republicanos (27\%) (Herrnson, 1997, p. 203).

Além do treino profissional, o espaço ocupado pelos segmentos profissionais no interior da classe política depende também da oferta de candidatos disponíveis desses segmentos na sociedade: se seu número 
absoluto é extremamente reduzido, a probabilidade maior, se todos os demais fatores forem iguais, é de que os membros desses grupos sejam numericamente pouco expressivos no interior do sistema político. Contudo, a quantidade não é, nem de longe, a variável mais relevante porque cada meio profissional e ocupacional específico (como empresários e proprietários, jornalistas, advogados, professores, padres e pastores etc.) é sempre muito minoritário ante a massa de eleitores e, no entanto, são desses segmentos que sai a maior parte dos políticos. ${ }^{8}$ Além da dimensão quantitativa da oferta de candidatos à classe política, outras variáveis contam, tais como recursos materiais, instrução, redes familiares e sociais, apoios associativos e corporativos e atividades profissionais que proporcionem tempo disponível para dedicar-se à política, especialmente no início, quando os protopolíticos ainda não podem obter rendimentos da atividade, isto é, não se transformaram em políticos profissionais e não estão ainda vivendo da política.

Como já mencionamos, a representação dos segmentos ocupacionais assinalados no interior dos partidos varia com as mudanças que ocorrem na estrutura social, nas instituições, nas leis eleitorais e no desenvolvimento da própria organização partidária. Portanto, a composição interna do pessoal político, mesmo quando certas profissões e ocupações se prestam melhor para a participação política, dificilmente deixa de refletir as fases de desenvolvimento econômico e o formato do regime. ${ }^{9}$ Sendo assim, a composição e as características do corpo político estão sujeitas às idas e vindas das disputas pelo poder e podem sofrer mudanças radicais no caso de eventos marcantes que interrompam bruscamente uma linha de continuidade institucional e inaugurem uma "nova época".

\footnotetext{
${ }^{8}$ Aqui estamos pensando em sociedades democráticas em que a via para o poder são as disputas eleitorais. No Brasil e em outros países menos desenvolvidos, as Forças Armadas deveriam ser incluídas entre os meios de recrutamento de lideranças políticas. Mas a ampla participação de militares na política, mesmo em situação de normalidade constitucional, é sempre sinal de um sistema democrático instável e de fraca profissionalização da política. Afinal, como assinalou Shumpeter, "a democracia é o governo dos políticos" (Shumpeter, 1961, p. 316).

9 As regras partidárias e eleitorais de escolha dos candidatos constituem outra variável importante a afetar a natureza das bancadas e de suas lideranças, como acentuam, por exemplo, Fowler \& McClure, 1989; Norris \& Lovenduski, 1997 e Rush, 1969.
}

\section{O caso brasileiro}

À luz dos dados que apresentamos, caberia indagar em que medida a composição socio-ocupacional do Legislativo federal brasileiro difere significativamente da que existe nos países de tradição democrática mais antiga e sólida, com sistemas partidários supostamente muito mais eficientes, organizados e representativos do que os nossos. Seria difícil tentar qualquer resposta mais específica sem que muitas outras páginas fossem acrescentadas a este texto. Na rubrica "países de tradição democrática mais antiga e sólida" está um leque de situações que são diferentes hoje no próprio bloco das democracias ricas e que variaram no tempo no interior de cada uma delas.

Apesar das diferenças entre os países e das variações ao longo das histórias nacionais, a rápida vista-d'olhos nas profissões/ocupações das bancadas parlamentares de alguns países não conduziu à confirmação da tese de que, pelo menos desse ângulo, os partidos brasileiros são um exemplo aberrante no panorama das democracias contemporâneas, embora o peso dos segmentos empresariais, no nosso caso, pareça mais alto.

Para comparações mais precisas, porém, seria necessário levar em conta as diferenças das metodologias adotadas pelos pesquisadores nos vários países para a classificação das origens profissionais dos parlamentares. Seria possível dizer que, em nossa pesquisa, os critérios que utilizamos ampliaram a classe dos empresários e proprietários em geral ao nela incluir os administradores, gerentes, proprietários de escolas, de hospitais e de todo tipo de empreendimento capaz de produzir lucro. A inclusão desses segmentos, contudo, levou a um crescimento muito pequeno da categoria dos "empresários": apenas $2,4 \%$ no total da CD. Por isso não achamos que o amplo espaço dos empresários na classe política brasileira se deva a uma questão de metodologia. Para explicar o fato seria necessário examinar outras variáveis sociais e institucionais que afetam a competição política no País, tarefa que claramente exigiria outra pesquisa. Fica, portanto, apenas a constatação do fenômeno.

Já com relação a outras categorias ocupacionais, as diferenças entre o Brasil e os outros países não parecem tão profundas. A diminuta proporção de trabalhadores manuais e de lavradores encontrada na nossa CD, como vimos, não é muito diferente da de outros países desenvolvidos, onde 
também os trabalhadores e membros das classes baixas são minoritários, inclusive nas bancadas dos partidos de esquerda. Encontramos semelhanças entre nós e eles também no peso de determinadas categorias socioprofissionais. Em toda parte, e não somente no Brasil, o melhor indicador do grau de esquerdismo tende a ser a proporção de professores nas bancadas partidárias, entre outras coisas, porque a presença de trabalhadores manuais é pequena e a de sindicalistas do setor privado está declinando. Consequentemente, quanto mais professores, mais à esquerda tende estar o partido. Mas uma distinção deve ser feita de maneira a se considerar separadamente as orientações ideológicas da "baixa docência" e as da "alta docência", isto é, os professores do magistério elementar e os do segundo grau com professores do ensino superior e, especialmente, os das grandes universidades e os de outras menos importantes. Trata-se de um aspecto que provavelmente teria relações com as preferências partidárias mas que não pôde ser examinado aqui pela dificuldade em identificar com precisão, na coleta de dados, os níveis e setores do magistério. ${ }^{10}$

Por fim, cabe chamar a atenção para uma variável de natureza institucional que vem das regras do sistema eleitoral. A composição das bancadas partidárias depende da política de oferta de candidatos aos eleitores por parte dos partidos. Essa política, entre muitos outros fatores, sofre a influência do sistema eleitoral em vigor em cada país. No caso dos sistemas eleitorais de tipo distrital (plurality) que favorecem o bipartidarismo, a apresentação de candidaturas em "circunscrições seguras" (em que tradicionalmente um dos partidos costuma ter a preferência dos eleitores) aumenta muito as chances de quem concorre pela legenda habitualmente vencedora. Além disso, esses sistemas tornam mais transparentes as estratégias dos partidos, ou melhor, de suas direções, com relação aos tipos de representantes que desejam ter no Parlamento, levando em conta as probabilidades de agradar aos eleitores. Para os candidatos de "distritos seguros", para os que desejam entrar para a classe política, ganhar numa circunscrição significa ganhar antes noutra arena, isto é, conseguir ser apresentado como candidato pela máquina partidária local. Em alguns países, como na Austrália e no Reino Unido, essa indicação requer dos

\footnotetext{
${ }^{10}$ Em português, a mesma palavra (professor) é habitualmente utilizada para designar docentes de todos os níveis do ensino, enquanto em outros países o próprio idioma já estabelece uma distinção.
}

candidatos bom tempo de militância no partido. ${ }^{11}$ Consequentemente, as composições das bancadas dependem mais das ofertas das direções dos partidos (ou de seus organismos locais, quando elas dispõem de alguma autonomia) do que das escolhas dos eleitores.

\section{Conclusão}

O número de países referidos antes é muito limitado para deles se extrair conclusões mais seguras. Os exemplos da distribuição socioocupacional de outros parlamentos que citamos destinaram-se somente a permitir alguma comparação com a situação brasileira. Apesar disso, pensamos que, à luz desses primeiros dados, os seguintes elementos de similitude entre o Brasil e os outros países podem ser indicados:

1. Heterogeneidade e seletividade ocupacional no recrutamento de membros e candidatos por parte de partidos de tendências ideológicas diferentes, incidindo sobre um pequeno grupo de categorias profissionais, como os professores, os profissionais liberais, os funcionários públicos e os empresários.

2. Importância de categorias como funcionários, professores e profissionais liberais, das talking professions e das profissões que permitem mais tempo livre e/ou grande flexibilidade no horário de trabalho sem graves prejuízos para a renda pessoal, como acontece com alguns tipos de funcionários públicos, com os professores, com os jornalistas, com os intelectuais e com os dirigentes sindicais.

3. Participação relevante, mas minoritária dos empresários, executivos e homens de negócio no interior dos parlamentos das democracias capitalistas.

\footnotetext{
${ }^{11}$ Os partidos australianos funcionam segundo rígida disciplina parlamentar, especialmente o Labour Party. Votos contrários às decisões dos partidos são extremamente raros. A média de tempo de filiação partidária, de militância e trabalho voluntário no partido era de 12,3 anos para candidatos à Câmara de Representantes australiana. (McAllister, 1997, p. 20). No Reino Unido, a força dos aparelhos partidários pode ser percebida na indicação dos candidatos ao Parlamento: quando das eleições gerais de 1992, 95\% dos candidatos do Partido Trabalhista e $90 \%$ dos candidatos do Partido Conservador haviam sido indicados pelas organizações locais desses partidos (Norris Lovenduski, 1995, p. 89, apud McAllister, 1997).
} 
4. Baixa proporção de parlamentares originários das classes operárias e populares e, mais ainda, de agricultores e camponeses.

5. Aumento, no interior dos partidos, da proporção de empresários, homens de negócios, comerciantes e pessoas de classe alta à medida que se caminha para a direita do espectro ideológico e, num sentido contrário, aumento de políticos de classe média (intelectuais, funcionários, professores do ensino médio), e em menor medida, de trabalhadores (geralmente, sindicalistas) quando se caminha para o centro e para a esquerda.

\section{PERFIS OCUPACIONAIS POR REGIÃO}

Este capítulo focaliza a composição socioeconômica da Câmara dos Deputados do prisma das regiões e unidades das federações. Nas bancadas do Norte e Nordeste, os empresários estão fortemente representados. A proporção de parlamentares vindos das classes trabalhadores é relativamente mais elevada no Sul. Nesse Estado, a proporção de ex-funcionários é muito baixa. No que tange aos Estados, é no Rio que se encontrou a maior proporção de parlamentares vindos do setor público, especialmente do baixo funcionalismo. A porcentagem de deputados que foram diretores de bancos estatais é, comparativamente, alta na bancada de Minas Gerais.

\section{As diferenças regionais}

As formas específicas de estrutura social e outras características locais devem, de algum modo, aumentar ou diminuir a importância dos vários segmentos ocupacionais e profissionais como celeiros de abastecimento das facções da classe política. Nas áreas de níveis mais baixos de modernização e desenvolvimento - como mostra a história política de outros países -, parcela majoritária da classe política vem habitualmente das camadas altas. Essa tendência principal não exclui desenvolvimentos nacionais particulares, retrocessos por períodos mais ou menos longos, desdobramentos nacionais mais demorados e variados.

Apesar disso, o desenvolvimento das sociedades ocidentais foi na direção da ampliação do sufrágio e da participação das classes médias e trabalhadoras no sistema decisório. A democratização do sistema político, a ampliação do corpo eleitoral e a diversificação da representação são fenômenos vinculados à expansão do capitalismo industrial e à modernização das sociedades ocidentais.

No caso brasileiro, o processo, de modo geral, foi semelhante. Ao longo do desenvolvimento econômico e da modernização do País, as elites tradicionais, vindas das velhas famílias e da oligarquia rural, foram perdendo espaço no interior da classe política para lideranças políticas saídas da classe empresarial de origem imigrante mais recente, das novas classes médias e, mais ultimamente, das classes trabalhadoras. No plano 
nacional, o sentido desse desenvolvimento é incontestável embora se possa discutir seu ritmo, sua extensão e suas consequências.

Mas há muitas diferenças quanto aos níveis de modernização das regiões do País e quanto às configurações políticas regionais. $\mathrm{O}$ esquema esperado de correspondência entre o político e o social, segundo modelo do ocorrido em outras épocas e entre outros países, no momento, está reproduzido apenas parcialmente nas regiões brasileiras.

De modo mais concreto: embora seja possível localizar padrões e regularidades regionais nas conexões entre as bancadas dos partidos e seus ambientes, cumpre proceder com prudência quando se pensa em generalizações. No que tange às relações entre a importância de certos segmentos socio-ocupacionais de classe alta, por um lado, e o grau de modernização das regiões no seu conjunto, por outro, somente algumas tendências muito gerais podem ser constatadas quando se comparam as cinco grandes regiões. A estrutura social de cada uma, e de cada Estado, fornece apenas um dado tipo de cenário no qual se travam as disputas políticas cujo desenrolar é influenciado pelas histórias políticas locais, conflitos entre chefes políticos de natureza variada, acordos que se estabelecem segundo uma lógica conjuntural dos cálculos de ganhos e perdas.

Desse modo, por exemplo, os deputados que são ou foram empresários ocupam quase a metade das bancadas no Norte e Nordeste. Nessas duas regiões, há pouquíssimos deputados que foram trabalhadores e empregados. A conclusão quase instantânea, principalmente pelos dados sobre a força dos partidos nas regiões, seria de que, nas mais atrasadas, as elites políticas originárias das classes empresariais e das classes altas, de modo geral, tenderiam a predominar. Mas a relação entre graus de modernização e composição da classe política local é mais complexa e requer análises mais detalhadas. O grupo empresarial tem mais peso no Sul do que no Sudeste, embora esta última região seja a mais desenvolvida e modernizada. A proporção de parlamentares originários das classes trabalhadoras é maior no Rio Grande do Sul do que em São Paulo, bem mais industrializado; a proporção de parlamentares do Norte que eram profissionais liberais ou tinham ocupações intelectuais é a mais baixa entre todas as regiões, porém muito próxima das encontradas no Sul e no CentroOeste. No Nordeste, a proporção de ex-profissionais liberais é elevada, mas a de professores é baixa. Já no Norte, os parlamentares que vieram do magistério são numerosos, com proporção aproximada à encontrada no Sul.

$\mathrm{Na}$ verdade, os padrões partidários regionais, como não poderia deixar de ser, dependem das suas unidades constitutivas. Essas unidades, quer dizer, os Estados, formam uma arena política própria, com forte autonomia ante o sistema político nacional. Cada unidade da Federação é um sistema (ou um subsistema) com feições próprias. O resultado é que cada Estado pode ter traços muito diferentes dos que predominam na região a qual pertence.

O fator determinante é a força de cada partido na região e nos Estados. Se um segmento ocupacional é expressivo num partido, e esse partido é forte na circunscrição em apreço, esse segmento ocupacional tenderá também a ser expressivo na bancada da circunscrição. Esta é uma primeira observação necessária para orientar a próxima análise. A segunda destina- se a chamar a atenção para o fato de que, agora, estaremos trabalhando com todos os partidos parlamentares e não apenas com os seis cuja relação entre composição social e ideologia foi examinada.

Os deputados que foram (ou são) empresários representam $48 \%$ das bancadas do Norte e do Nordeste. As profissões liberais e intelectuais são particularmente expressivas no Nordeste (38\%). Está também no Nordeste, em comparação com outras regiões, a maior porcentagem $(24 \%)$ de deputados que tinham cargos na administração pública (governos federal, estaduais e municipais); a menor está no Sul (8\%) ${ }^{1}$. Os professores, considerando todos os níveis do magistério, estavam fracamente representados no Nordeste $(9 \%)$, porcentagem que sobe para $20 \%$ no Norte e no Sudeste. Os deputados que foram trabalhadores manuais, lavradores ou empregados não manuais do setor de serviços — das classes populares, de modo geral - representavam 9\% das bancadas dos Estados do Sul, 5\% das do Sudeste e Centro-Oeste, mas só 3\% das do Norte e do Nordeste.

\footnotetext{
${ }^{1}$ Estão excluídos da base de cálculos os diretores de bancos estatais. Esse segmento representa 3\% das bancadas regionais do Norte, Nordeste, Sudeste e Sul, inexistindo no Centro-Oeste.
} 
Tabela 10

Profissões/Ocupações por região $(\%)$

\begin{tabular}{|c|c|c|c|c|c|c|}
\hline \multirow[t]{2}{*}{ Profissões/Ocupações } & \multicolumn{6}{|c|}{ Região } \\
\hline & $\mathrm{N}$ & $\mathrm{NE}$ & SE & $\mathrm{S}$ & $\mathrm{CO}$ & $\mathrm{CD}$ \\
\hline Empresários urbanos & 27,7 & 27,8 & 29,1 & 31,2 & 24,4 & 28,5 \\
\hline Empresários rurais & 18,5 & 13,9 & 5,6 & 5,2 & 12,2 & 10,1 \\
\hline Empresários mistos & 1,5 & 6,6 & 4,5 & 5,2 & 4,9 & 4,9 \\
\hline $\begin{array}{l}\text { Profissões liberais } \\
\text { tradicionais }\end{array}$ & 21,5 & 34,4 & 23,5 & 26,0 & 26,8 & 27,1 \\
\hline $\begin{array}{l}\text { Profissões } \\
\text { intelectuais }\end{array}$ & 6,2 & 3,3 & 6,1 & 2,6 & 2,4 & 4,5 \\
\hline $\begin{array}{l}\text { Magistério público } \\
\text { superior }\end{array}$ & 7,7 & 5,3 & 6,7 & 5,2 & 9,8 & 6,4 \\
\hline Outros professores & 12,3 & 3,3 & 13,4 & 6,5 & 14,6 & 9,4 \\
\hline $\begin{array}{l}\text { Altos cargos do } \\
\text { governo federal }\end{array}$ & 4,6 & 6,6 & 5,0 & 1,3 & 4,9 & 4,9 \\
\hline $\begin{array}{l}\text { Altos cargos dos } \\
\text { governos estaduais }\end{array}$ & 9,2 & 14,6 & 6,1 & 5,2 & 7,3 & 9,0 \\
\hline $\begin{array}{l}\text { Altos cargos dos } \\
\text { governos municipais }\end{array}$ & 0 & 1,3 & 3,4 & 1,3 & 0 & 1,8 \\
\hline $\begin{array}{l}\text { Baixo e médio } \\
\text { funcionalismos } \\
\text { públicos }\end{array}$ & 3,1 & 1,3 & 2,2 & 0 & 2,4 & 1,8 \\
\hline $\begin{array}{l}\text { Diretores de bancos } \\
\text { estatais }\end{array}$ & 3,1 & 2,6 & 2,8 & 2,6 & 0 & 2,5 \\
\hline Comunicadores & 4,6 & 3,3 & 8,9 & 5,2 & 12,2 & 6,4 \\
\hline Pastores e padres & 3,1 & 2,6 & 5,0 & 3,9 & 0 & 3,5 \\
\hline $\begin{array}{l}\text { Empregados não } \\
\text { manuais em serviços }\end{array}$ & 0 & 3,3 & 2,8 & 2,6 & 4,9 & 2,7 \\
\hline $\begin{array}{l}\text { Trabalhadores } \\
\text { industriais } \\
\text { qualificados }\end{array}$ & 1,5 & 0 & 1,7 & 3,9 & 0 & 1,4 \\
\hline Lavradores & 1,5 & 0 & 0 & 2,6 & 0 & 0,6 \\
\hline "Políticos" & 0 & 0,7 & 1,1 & 1,3 & 0 & 0,8 \\
\hline Sem informação & 1,5 & 0 & 0,6 & 0 & 0 & 0,4 \\
\hline $\begin{array}{l}\text { Soma das \% das } \\
\text { profissões/ocupações }\end{array}$ & 127,6 & 130,9 & 128,5 & 111,8 & 126,8 & 126,7 \\
\hline $\mathrm{N}$ & 65 & 151 & 179 & 77 & 41 & 513 \\
\hline
\end{tabular}

Obs.: A soma das porcentagens é maior do que $100 \%$ porque há deputados com mais de uma profissão/ocupação.

\section{Região norte: as diferenças internas}

A apreensão mais exata da composição da representação parlamentar nortista requer um exame das características das unidades que integram a região. Por isso, examinaremos separadamente os Estados que compõem o que denominamos "Norte Novo" (Acre, Amapá, Rondônia, Roraima e Tocantins) e os que formam o "Norte Antigo" (Amazonas e Pará).

Norte Novo - A representação parlamentar na CD desse bloco é amplamente dominada pelos empresários que compõem a metade do total dos deputados da sub-região (vinte parlamentares). No Acre e em Roraima, entre os empresários, predominam os de atividade rural. Após o grupo empresarial, vêm os parlamentares do setor público, os profissionais liberais e os professores. Esses quatro segmentos ocupam quase todo o espaço de representação do Norte Novo. No total dos cinco Estados, todos os parlamentares possuem pelo menos uma dessas profissões/ocupações (tabela 11).

Norte Antigo - Do ponto de vista socioprofissional, o perfil do Estado do Amazonas aproxima-se do dos pequenos Estados do Norte Novo em razão do enorme peso dos empresários: entre os oito deputados eleitos pelo colégio eleitoral desse Estado, seis tinham (ou têm) atividades empresariais; dois foram professores e um era profissional liberal.

Contudo, o perfil social da bancada do Pará (dezessete cadeiras na CD) aproxima-se mais do de outros grandes Estados no sentido de haver maior heterogeneidade no recrutamento político. Em parte, isso é devido à maior magnitude dessa circunscrição eleitoral. Os parlamentares que vieram do meio empresarial repartem a primeira posição com os que eram profissionais liberais: cinco casos, respectivamente. Quatro parlamentares foram professores e há também um caso de trabalhador manual qualificado e um ex-lavrador. 
Tabela 12

Tabela 11

Norte Novo: profissões/ocupações (n.a.)

\begin{tabular}{l|c|c|c|c|c|c}
\multicolumn{1}{c|}{ Profissões/Ocupações } & $\mathrm{AC}$ & $\mathrm{AP}$ & $\mathrm{RO}$ & $\mathrm{RR}$ & $\mathrm{TO}$ & Total \\
\hline Empresários urbanos & 1 & 2 & 2 & 2 & 3 & 10 \\
\hline Empresários rurais & 4 & 0 & 1 & 3 & 1 & 9 \\
\hline Empresários mistos & 0 & 0 & 0 & 0 & 1 & 1 \\
\hline Profissões liberais tradicionais & 1 & 1 & 3 & 3 & 1 & 9 \\
\hline Profissões intelectuais & 0 & 2 & 0 & 1 & 0 & 3 \\
\hline Magistério público superior & 1 & 1 & 0 & 0 & 0 & 2 \\
\hline Outros professores & 2 & 1 & 2 & 0 & 0 & 5 \\
\hline Altos cargos do governo federal & 1 & 0 & 0 & 1 & 0 & 2 \\
\hline $\begin{array}{l}\text { Altos cargos de governos } \\
\text { estaduais }\end{array}$ & 1 & 0 & 1 & 0 & 2 & 4 \\
\hline $\begin{array}{l}\text { Altos cargos de governos } \\
\text { municipais }\end{array}$ & 0 & 0 & 0 & 0 & 0 & 0 \\
\hline Baixo e médio funcionalismos & 1 & 0 & 0 & 0 & 1 & 2 \\
\hline Diretores de bancos estatais & 0 & 0 & 0 & 0 & 1 & 1 \\
\hline Comunicadores & 1 & 0 & 0 & 0 & 0 & 1 \\
\hline Pastores e padres & 0 & 0 & 0 & 0 & 1 & 1 \\
\hline $\begin{array}{l}\text { Empregados não manuais em } \\
\text { serviços }\end{array}$ & 0 & 0 & 0 & 0 & 0 & 0 \\
\hline $\begin{array}{l}\text { Trabalhadores industriais } \\
\text { qualificados }\end{array}$ & 0 & 0 & 0 & 0 & 0 & 0 \\
\hline Lavradores & 0 & 0 & 0 & 0 & 0 & 0 \\
\hline "Políticos" & 13 & 8 & 9 & 10 & 11 & 50 \\
\hline Sem informação & 8 & 8 & 8 & 8 & 40 \\
\hline $\begin{array}{l}\text { Soma das \% das } \\
\text { profissões/ocupações }\end{array}$ & 0 & 0 & 0 & 0 \\
\hline N & 0 & 0 & 0 & 0 & 0 \\
\hline & 1 & & & \\
\hline
\end{tabular}

Norte Antigo: Profissões/ocupações (n.a.)

Profissões/Ocupações

\begin{tabular}{l|c|c|c}
\hline Empresários urbanos & 6 & 2 & 8 \\
\hline Empresários rurais & 0 & 3 & 3 \\
\hline Empresários mistos & 0 & 0 & 0 \\
\hline Profissões liberais tradicionais & 0 & 5 & 5 \\
\hline Profissões intelectuais & 1 & 0 & 1 \\
\hline Magistério público superior & 1 & 2 & 3 \\
\hline Outros professores & 1 & 2 & 3 \\
\hline Altos cargos do governo federal & 1 & 0 & 1 \\
\hline Altos cargos dos governos estaduais & 1 & 1 & 2 \\
\hline Altos cargos dos governos municipais & 0 & 0 & 0 \\
\hline Baixo e médio funcionalismos & 0 & 0 & 0 \\
\hline públicos & 0 & 1 & 1 \\
\hline Diretores de bancos estatais & 0 & 2 & 2 \\
\hline Comunicadores & 0 & 1 & 1 \\
\hline Pastores e padres & 0 & 0 & 0 \\
\hline Empregados não manuais em serviços & 0 & 1 & 1 \\
\hline Trabalhadores manuais qualificados & 0 & 1 & 1 \\
\hline Lavradores & 0 & 0 & 0 \\
\hline "Políticos" & 0 & 0 & 0 \\
\hline Sem informação & 11 & 21 & 32 \\
\hline Soma das \% das profissões/ocupações & 8 & 17 & 25 \\
\hline N & 0 & & \\
\hline
\end{tabular}

As principais características da região podem ser visualizadas de modo mais rápido se agruparmos as categorias profissionais da tabela 12 nos quatro grupos principais de recrutamento da classe política brasileira: as camadas empresariais, as profissões liberais tradicionais (médicos e advogados, na sua maioria), a burocracia pública e o magistério. Os empresários de todos os setores compõem $48 \%$ da bancada da região Norte. 
Em seguida, estão os profissionais liberais e os professores. Os que tinham cargos no setor público vêm em quarto lugar. (Em razão do pequeno número de casos na maioria das caselas, os dados da tabela estão em números absolutos. Os totais estão em porcentagens).

\section{Tabela 13}

Região Norte - Principais categorias ocupacionais agregadas (n.a.)

\begin{tabular}{c|c|c|c|c|c|c|c|c} 
Profissão/Ocupação & $\mathrm{PA}$ & $\mathrm{AC}$ & $\mathrm{AM}$ & $\mathrm{AP}$ & $\mathrm{RO}$ & $\mathrm{RR}$ & $\mathrm{TO}$ & Total \\
\hline Empresários & 5 & 5 & 6 & 2 & 3 & 5 & 5 & 47,7 \\
\hline Profissões liberais & 5 & 1 & 0 & 1 & 3 & 3 & 1 & 21,5 \\
\hline Magistério & 4 & 3 & 2 & 2 & 2 & 0 & 0 & 20,0 \\
\hline Setor público & 1 & 3 & 2 & 0 & 1 & 1 & 3 & 16,9 \\
\hline $\mathrm{N}=65$ & 17 & 8 & 8 & 8 & 8 & 8 & 8 & 106,1
\end{tabular}

\section{O Nordeste}

Como no Norte, os empresários constituem o grupo de mais peso entre os deputados da região. Quase a metade dos integrantes da bancada nordestina tinha (ou tem) alguma atividade de tipo empresarial, urbana, rural ou mista. Seguem-se os deputados que exerciam alguma profissão liberal e os que tinham algum emprego na alta administração pública, especialmente nas burocracias estaduais. Ao contrário do que acontece no Norte, o grupo dos professores veio em quarto lugar. As classes trabalhadoras não forneceram nenhum deputado, mas há cinco que eram empregados não manuais do setor de serviços (quatro técnicos e um bancário).

A análise comparativa do perfil social das unidades que formam a região nordestina revela muitas variações entre os Estados, com fortes desníveis intra-regionais. Em Pernambuco, Paraíba, Alagoas e Sergipe, os parlamentares que foram (ou são) empresários compõe mais da metade das bancadas de cada um desses Estados. Em Pernambuco, chega mesmo a 64\%. Entre os deputados que foram (ou são) funcionários, a maior parte veio do alto funcionalismo estadual que, na região, é mais do dobro dos que saíram da administração federal. Já o funcionalismo municipal não é uma boa fonte de recrutamento para a classe política nordestina: somente dois parlamentares começaram a carreira política vindos da burocracia dos municípios.
Tal como foi feito para a região Norte, a fim de poder captar de modo mais rápido e compacto as diferenças nas variações ocupacionais entre os Estados nordestinos, a tabela seguinte traz os resultados agregados nos quatro grandes segmentos que compõem a classe política brasileira da região.

A proporção de deputados que foram (ou são) profissionais liberais, na região Nordeste, está um pouco acima da proporção nacional que é de $32 \%$. A de empresários já é mais elevada. Em comparação com os $48 \%$ da bancada nordestina, no total da $\mathrm{CD}$, há $44 \%$. No setor público, a diferença com relação à $\mathrm{CD}$ é também elevada: $24 \%$ contra $18 \%$. Mas com relação aos professores, em cotejo com os $16 \%$ de docentes da $\mathrm{CD}$, há somente $9 \%$ de deputados que exerciam o magistério.

Em contraposição, quanto às classes populares, a região como um todo possui somente $3 \%$ de parlamentares que, quando entraram na classe política, eram empregados não manuais do setor de serviços. Em troca, não há, em todas as unidades que formam a região, trabalhadores industriais, proporção que, na $\mathrm{CD}$, é também bastante baixa (1\%). 


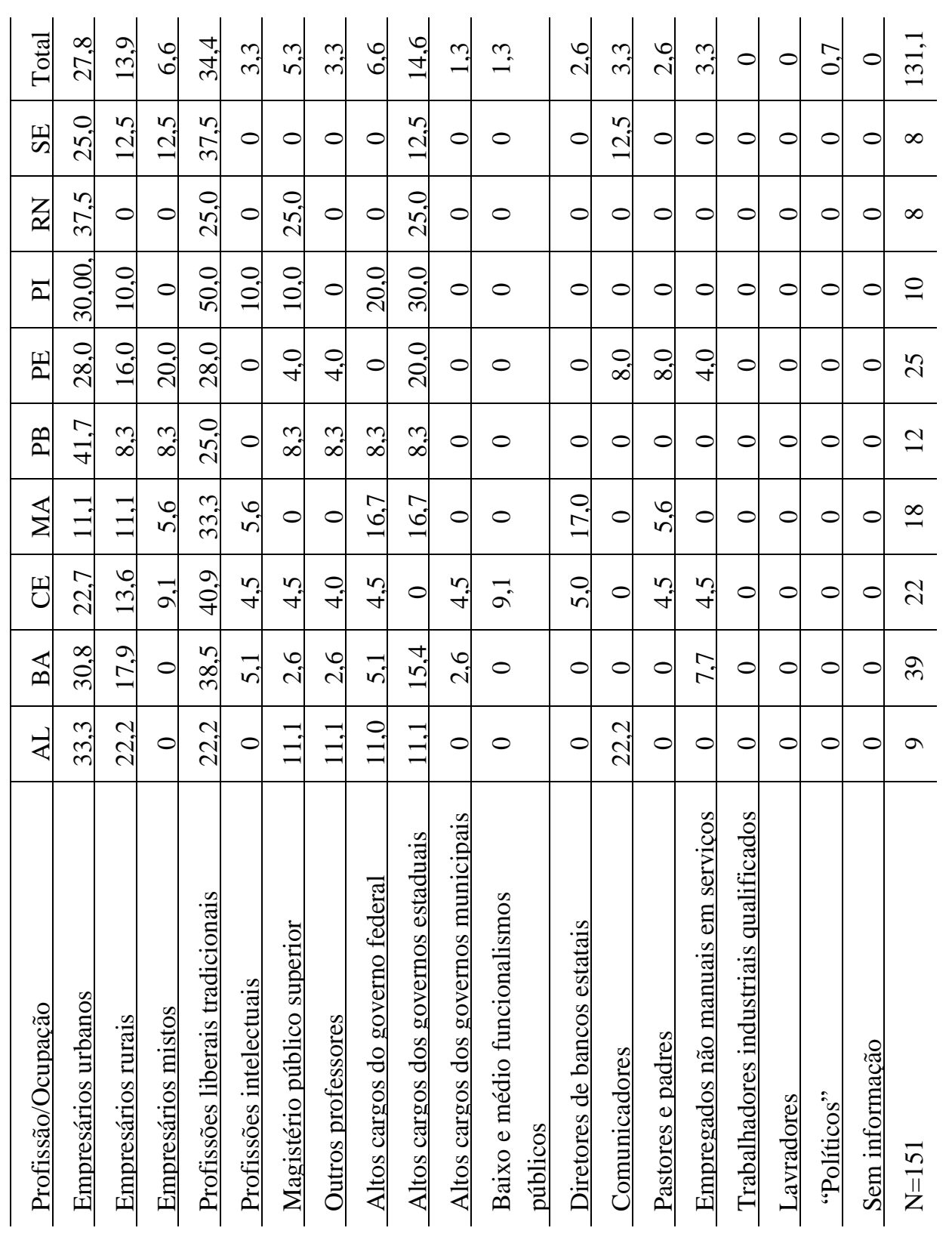

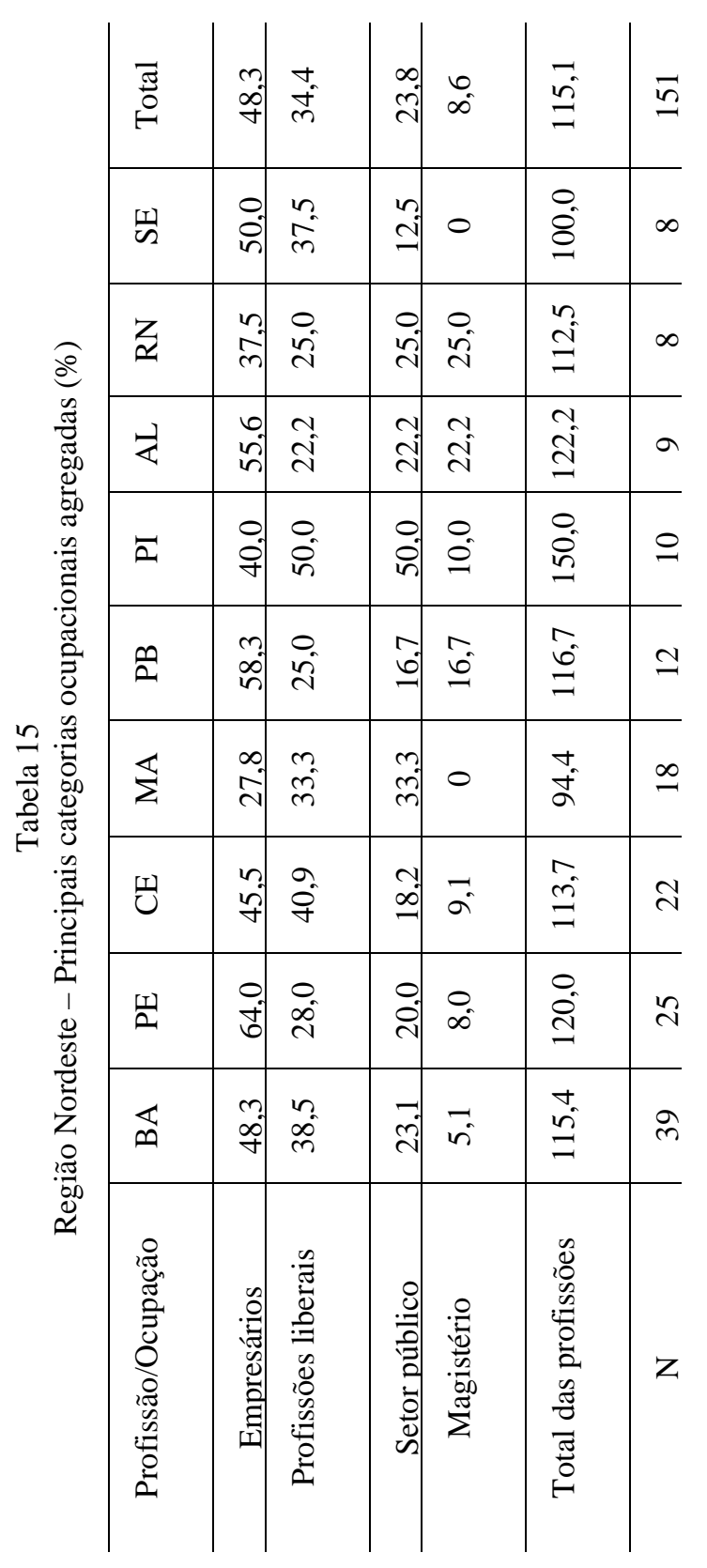




\section{O Sudeste}

Tal como nas regiões anteriormente examinadas, há diferenças fortes entre os Estados do Sudeste quanto aos meios sociais de recrutamento para a classe política. A proporção de empresários do setor urbano, na bancada paulista $(31 \%)$, é a mais elevada dos três Estados. Mas, no tocante à proporção de empresários do setor rural, Minas está à frente de São Paulo e do Rio de Janeiro. Neste último, nenhum parlamentar era (ou é) empresário rural. Na verdade, na bancada carioca, não há também empresários do setor misto.

Na bancada mineira, chama a atenção a baixa proporção de exprofissionais liberais (somente 13\%), muito inferior à encontrada nos outros Estados. Quanto ao setor público, do alto funcionalismo federal, o dado saliente é a baixíssima proporção, na bancada paulista, de deputados que vieram desse segmento (1\%), em contraposição aos $10 \%$ do Espírito Santo, $8 \%$ de Minas e $7 \%$ do Rio. (Do total da região, $19 \%$ dos integrantes da bancada do Sudeste saíram dos vários escalões do setor público.) Aqui, chama ainda a atenção o fato de não se encontrar na bancada potiguar nenhum parlamentar que tenha vindo do funcionalismo estadual ou municipal ou do baixo funcionalismo em geral. Mas deve-se levar em conta que, no caso desse Estado, lidamos com um número baixo de casos (apenas dez deputados).

Ainda em Minas, o dado que chama a atenção são os $6 \%$ dos integrantes da bancada que foram diretores de bancos estatais. A proporção, em termos absolutos, pode parecer baixa, mas, desse grupo profissional, não havia nenhum parlamentar na bancada paulista e somente $2 \%$ na carioca. A bancada do Espírito Santo registra 10\% de ex-diretores de bancos do Estado (um caso), mas vale aqui a observação precedente quanto à baixa magnitude desse colégio eleitoral.

Com relação ainda ao setor governamental como fonte de recrutamento para a classe política, vale notar - contando todos os escalões e níveis de governo - que a bancada do Rio, com $26 \%$, supera todas as outras, possuindo mais do dobro (sempre em termos percentuais) de deputados que foram funcionários do que São Paulo (11\%), Minas (17\%) e Espírito Santo (10\%) e bem superior ao total da CD (18\%). Nesse ponto, o traço peculiar da bancada carioca, ao contrário das demais, é a proporção relativamente elevada de deputados que vieram do baixo e médio funcionalismos $(7 \%)$, bem mais alta do que os $2 \%$ do total da região. Devese notar que, na Câmara, só 3\% dos parlamentares vieram desse segmento.

Por fim, no que diz respeito à bancada mineira, salienta-se que, embora a magnitude desse colégio eleitoral seja elevada, com 53 deputados, não há, nela, nenhum parlamentar originário das classes populares. Mas a proporção desses casos é pequena também em São Paulo e no Rio (3\% e $4 \%$, respectivamente). Em contraposição, o número de comunicadores na bancada mineira (13\%) é o maior entre os quatro Estados.

Tabela 16

Região Sudeste - Principais categorias profissionais (\%)

\begin{tabular}{l|c|c|c|c|c} 
Profissão/Ocupação & SP & MG & RJ & ES & Total \\
\hline Empresários urbanos & 31,4 & 28,3 & 26,1 & 30,0 & 29,1 \\
\hline Empresários rurais & 4,2 & 13,2 & 0 & 0,0 & 5,6 \\
\hline Empresários mistos & 4,2 & 9,4 & 0 & 0 & 4,5 \\
\hline Profissões liberais tradicionais & 25,7 & 13,2 & 30,4 & 30 & 23,5 \\
\hline Profissões intelectuais & 5,7 & 7,5 & 6,5 & 0 & 6,1 \\
\hline Magistério público superior & 8,6 & 5,6 & 4,3 & 10,0 & 6,7 \\
\hline Outros professores & 17,1 & 13,2 & 10,9 & 0 & 13,4 \\
\hline Altos cargos do governo federal & 1,4 & 7,5 & 6,5 & 10,0 & 5,0 \\
\hline Altos cargos dos governos estaduais & 7,1 & 3,8 & 8,7 & 0 & 6,1 \\
\hline Altos cargos dos governos municipais & 2,9 & 3,8 & 4,3 & 0 & 6,1 \\
\hline Baixo e médio funcionalismos públicos & 0 & 1,8 & 6,5 & 0 & 2,2 \\
\hline Diretores de bancos estatais & 0 & 5,7 & 2,1 & 10,0 & 2,8 \\
\hline Comunicadores & 7,1 & 13,2 & 8,7 & 0 & 8,9 \\
\hline Pastores e padres & 4,3 & 3,8 & 6,5 & 10,0 & 5,0 \\
\hline Empregados não manuais em serviços & 2,9 & 0 & 4,3 & 10,0 & 2,8 \\
\hline Trabalhadores industriais qualificados & 2,9 & 0 & 1 & 0 & 1,7 \\
\hline Lavradores & 0 & 0 & 0 & 0 & 0 \\
\hline "Políticos" & 1,4 & 0 & 0 & 10,0 & 1,1 \\
\hline Sem informação & 0 & 0 & 0 & 10,0 & 0,6 \\
\hline Total das profissões/ocupações (\%) & 126,9 & 130,0 & 126,8 & 140,0 & 131,2 \\
\hline N & 70 & 53 & 46 & 10 & 179 \\
\hline
\end{tabular}


Obs.: As somas das porcentagens são maiores do que $100 \%$ porque há deputados com mais de uma profissão/ocupação.

A tabela 17, com os resultados agregados dos quatro principais segmentos ocupacionais, permite uma apreensão sintética das diferenças entre as unidades do Sudeste. A bancada com maior proporção de empresários é a de Minas Gerais, com mais da metade dos seus integrantes recrutados dessa camada. Seguem São Paulo, Espírito Santo e Rio de Janeiro.

A elevada proporção de empresários entre os parlamentares mineiros reduz o espaço para outras profissões/ocupações, como os profissionais liberais, sempre uma fonte importante de abastecimento da classe política. Em Minas, os deputados que vieram desse segmento são apenas 13\%, proporção inferior à do total da região (24\%) e bem abaixo da de São Paulo $(26 \%)$ e da do Rio (30\%).

Com relação aos professores, a bancada paulista é a que possui a maior proporção: $26 \%$, quase o dobro da encontrada na carioca. Na verdade, também nas bancadas dos outros Estados há relativamente poucos professores.

Tabela 17

Região Sudeste - Principais categorias ocupacionais agregadas (\%)

\begin{tabular}{l|c|c|c|c|c} 
Profissão/Ocupação & SP & MG & RJ & ES & Total \\
\hline Empresários & 40,0 & 50,9 & 26,1 & 30,0 & 39,1 \\
\hline Profissões liberais & 25,7 & 13,2 & 30,4 & 30,0 & 23,5 \\
\hline Magistério & 25,7 & 18,9 & 15,2 & 10,0 & 20,1 \\
\hline Setor público & 11,4 & 17,0 & 26,1 & 10,0 & 16,8 \\
\hline Soma das \% & 102,8 & 100,0 & 97,8 & 80,0 & 99,5 \\
\hline $\mathrm{N}=179$ & 70 & 53 & 46 & 10 & 99,5
\end{tabular}

Obs.: Em algumas colunas, a soma das porcentagens é inferior a $100 \%$ porque outras profissões/ocupações além das indicadas na tabela não foram incluídas; em outra coluna, a soma é superior a $100 \%$ porque muitos parlamentares têm ou tiveram mais de uma ocupação/profissão.

\section{O Sul}

O conjunto dos Estados da região Sul distingue-se dos outros, especialmente do Nordeste, pela proporção muito baixa de seus parlamentares que vieram do setor público. Por exemplo: somente $8 \%$ contra $24 \%$ do Nordeste, a maior proporção do País. A porcentagem de deputados que vieram da área empresarial é de 42\%, abaixo da do Nordeste e da do Norte (48\%). Mas há fortes diferenças entre os três Estados sulistas. Na bancada do Paraná, 60\% eram (ou são) empresários, a segunda maior proporção entre os Estados depois de Pernambuco (64\%). ${ }^{2} \mathrm{Na}$ bancada paranaense, em compensação, a proporção de deputados que foram profissionais liberais é de somente $13 \%$, a mais baixa do País.

Tabela 18

Região Sul — Principais categorias ocupacionais agregadas (\%)

\begin{tabular}{l|c|c|c|c} 
Profissões/Ocupações & PR & SC & RS & Total \\
\hline Empresários & 60,0 & 31,3 & 29,0 & 41,6 \\
\hline Profissões liberais & 13,3 & 31,3 & 35,5 & 26,0 \\
\hline Magistério & 6,7 & 18,8 & 12,9 & 11,7 \\
\hline Setor público & 10,0 & 12,5 & 3,2 & 7,8 \\
\hline $\mathrm{N}=77$ & 30 & 16 & 31 & 87,1
\end{tabular}

No conjunto, os três Estados do Sul possuem o traço comum de possuírem, em suas bancadas, poucos deputados que vieram do setor público. No caso do Rio Grande do Sul, os dois aspectos que fazem esse Estado contrastar com os outros dois da própria região e mais ainda com os outros do País (com os do Nordeste particularmente) vêm: 1) da baixíssima proporção de deputados que eram funcionários públicos (3\%, um caso, na verdade) e 2) da proporção baixa dos que eram (ou são) empresários (29\%).

\footnotetext{
${ }^{2}$ Entre os Estados com magnitude 8, como Amazonas, Roraima e Tocantins, os empresários representam, respectivamente, $75 \%$; 63\% e $63 \%$ da bancada.
} 
Tabela 19

Região Sul - Categorias profissionais (n.a.)

\begin{tabular}{l|c|c|c|c} 
Profissões/Ocupações & PR & SC & RS & Total \\
\hline Empresários urbanos & 40,0 & 31,3 & 22,6 & 31,2 \\
\hline Empresários rurais & 6,7 & 0 & 6,5 & 5,2 \\
\hline Empresários mistos & 13,3 & 0 & 0 & 5,2 \\
\hline Profissões liberais tradicionais & 13,3 & 31,3 & 35,5 & 26,0 \\
\hline Profissões intelectuais & 3,3 & 0 & 3,2 & 2,6 \\
\hline Magistério público superior & 3,3 & 12,5 & 3,2 & 5,2 \\
\hline Outros professores & 3,3 & 6,3 & 9,7 & 6,5 \\
\hline Altos cargos do governo federal & 0 & 6,3 & 0 & 1,3 \\
\hline Altos cargos de governos estaduais & 6,7 & 6,3 & 3,2 & 5,2 \\
\hline Altos cargos de governos municipais & 3,3 & 0 & 0 & 1,3 \\
\hline Baixo e médio funcionalismos públicos & 0 & 0 & 0 & 0 \\
\hline Diretores de bancos estatais & 0 & 6,3 & 3,2 & 2,6 \\
\hline Comunicadores & 6,7 & 0 & 6,5 & 5,2 \\
\hline Pastores e padres & 6,7 & 0 & 3,2 & 3,9 \\
\hline Empregados não manuais em serviços & 3,3 & 6,3 & 0 & 2,6 \\
\hline Trabalhadores industriais qualificados & 0 & 0 & 9,7 & 3,9 \\
\hline Lavradores & 0 & 6,3 & 3,2 & 2,6 \\
\hline "Políticos" & 0 & 0 & 3,2 & 1,3 \\
\hline Sem informação & 0 & 0 & 0 & 0 \\
\hline N & 30 & 16 & 31 & 77
\end{tabular}

Essa proporção adquire maior significado ante a existência de $13 \%$ de trabalhadores manuais na bancada gaúcha (três metalúrgicos e um lavrador). Embora as comparações inter e intrarregionais revelem sempre a existência de singularidades, o caso gaúcho indica um padrão mais nitidamente diferenciado em razão da maior diversificação ocupacional no recrutamento da facção da classe política para a CD.

\section{O Centro-Oeste}

No conjunto do Centro-Oeste, os deputados que foram (ou são) empresários chegam a 42\%. A categoria dos empresários é seguida pela categoria dos profissionais liberais e pela dos professores (27\% e $24 \%)$. A proporção dos que foram funcionários antes de entrarem para a classe política é de apenas 15\%. No Distrito Federal, nenhum dos parlamentares veio do magistério, enquanto no Mato Grosso do Sul nenhum deles foi do setor público.

Tabela 20

Região Centro-Oeste - Principais categorias ocupacionais agregadas (\%)

\begin{tabular}{l|c|c|c|c|c} 
Profissões/Ocupações & GO & DF & MT & MS & Total \\
\hline Empresários & 47,1 & 37,5 & 37,5 & 37,5 & 41,5 \\
\hline Profissões liberais & 23,5 & 37,5 & 25,0 & 25,0 & 26,8 \\
\hline Magistério & 17,6 & 0 & 25,0 & 62,5 & 24,4 \\
\hline Setor público & 23,5 & 12,5 & 12,5 & 0 & 14,6 \\
\hline N & 17 & 8 & 8 & 8 & 41
\end{tabular}

\section{Conclusão}

A tabela 21 possibilita uma visão conjunta da distribuição das principais ocupações nas cinco regiões. Sem esquecer as discrepâncias existentes no interior de cada uma delas, pode-se ter uma visão comparativa geral das principais características sociais das bancadas. Com exceção do Sudeste, o grupo de deputados que eram (ou são) empresários está acima de $40 \%$ em todas as regiões, sendo que as porcentagens mais altas estão localizadas no Nordeste e Norte. A mais baixa proporção de empresários está no Sudeste. Mas, para esse resultado, pesaram muito os índices cariocas em que o setor empresarial forneceu poucos políticos para essa legislatura federal. Em contraposição, no tocante aos ex-funcionários públicos, os números do Rio (26\%) superam, ainda que ligeiramente, os do Nordeste. 
Em São Paulo, a proporção de parlamentares que veio da burocracia pública é de apenas $11 \%$, mas ainda assim superior à da região Sul como um todo e, notadamente, maior do que a do Rio Grande do Sul (3\%) e também do que a do Paraná (10\%), os únicos que estão, nesse aspecto, juntamente com o Pará (6\%), abaixo dos índices paulistas. Em São Paulo, em contrapartida, a proporção de deputados que veio do setor docente é a mais elevada (26\%) de todas as bancadas, com exceção da do Mato Grosso do Sul que possui cinco docentes entre seus oito deputados.

Seria tentador buscar conexões entre a composição social das bancadas partidárias nos Estados e as características do hábitat de onde saem suas lideranças e de onde obtêm votos. Um estudo, de Gláucio Ary Dillon Soares, hoje já um clássico no gênero, analisando em termos macro a votação dos partidos sob a constituição do de 1946, mostrou as relações entre variáveis socioeconômicas e variáveis políticas. ${ }^{3}$ Em princípio é difícil rejeitar a ideia de que as formações partidárias e as elites políticas não tenham algum tipo de relação com as características ambientais de onde são recrutadas as chefias partidárias.

Em geral, podemos aceitar que os partidos refletem, de algum modo, as especificidades de seu hábitat e concordar com Gláucio Ary Dillon Soares - sem cair em um rígido determinismo infraestrutural, que o autor rejeita - que o "desenvolvimento das forças produtivas é de importância fundamental para a compreensão do comportamento político, em geral, e das preferências partidárias, em particular" (Soares, 1973, p. 215). Mas é difícil, no caso de nosso objeto, passar das características ambientais para os reflexos na vida política, na organização partidária e, mais ainda, fixar algumas "leis" gerais para a explicação de casos concretos. Múltiplos fatores intervenientes específicos tendem a alterar a "norma" geral. Mais problemático ainda é

${ }^{3} \mathrm{O}$ autor distinguiu duas áreas geoeconômicas, a de São Paulo, a do Rio e a do então Estado da Guanabara, mais os Estados do Sul, representando o Brasil desenvolvido, e as demais regiões brasileiras, representando o Brasil subdesenvolvido. A pesquisa evidenciou relações significativas entre a força dos partidos e as características do meio socioeconômico. De modo geral, nos Estados mais desenvolvidos, os partidos de esquerda e os partidos de tipo populista tendiam a ser favorecidos enquanto, nas áreas mais atrasadas, os conservadores saíram-se melhor. Para mais informações, ver Soares (1973). localizar quais aspectos específicos são relevantes, porque certos resultados concretos vêm da correlação de múltiplos fatores que necessitariam ser controlados, tarefa difícil em virtude de seu intricado entrelaçamento.

Tabela 21

Principais ocupações agregadas por região (\%)

\begin{tabular}{c|c|c|c|c|c|c}
\multirow{2}{*}{ Profissões/Ocupações } & \multicolumn{7}{|c}{ Região } \\
\cline { 2 - 7 } & $\mathrm{N}$ & $\mathrm{NE}$ & $\mathrm{SE}$ & $\mathrm{S}$ & $\mathrm{CO}$ & $\mathrm{CD}$ \\
\hline Empresários & 47,7 & 48,3 & 39,1 & 41,6 & 41,5 & 43,5 \\
\hline $\begin{array}{l}\text { Profissões liberais } \\
\text { tradicionais }\end{array}$ & 21,5 & 34,4 & 23,5 & 26,0 & 26,8 & 27,1 \\
\hline Setor público & 16,9 & 23,8 & 16,8 & 7,8 & 14,6 & 17,5 \\
\hline Magistério & 20,0 & 8,6 & 20,1 & 11,7 & 24,4 & 15,0 \\
\hline $\mathrm{N}$ & 65 & 151 & 179 & 77 & 41 & 513
\end{tabular}

No nosso caso, qualquer tentativa de relacionar a composição das bancadas estaduais dos partidos e certos traços do sistema social das circunscrições eleitorais ultrapassaria os objetivos desta pesquisa. Para detectar, por exemplo, como as diferenças na dimensão da burocracia estatal podem ter efeitos sobre a composição das lideranças partidárias seria necessário um levantamento do peso das respectivas administrações locais. Mas, como se viu no exame das composições das bancadas, são os níveis superiores da burocracia pública, e não os mais baixos, que aumentam as proporções do setor público no interior da classe política. Estudos que procurassem encontrar ligações entre o volume de funcionários nos Estados e a proporção de funcionários nas bancadas teriam que levar em conta essa particularidade. Nesse aspecto, quer dizer, nos diferenciais relativos à capacidade dos variados setores de se transformarem em celeiros de abastecimento de quadros políticos, muitas outras variáveis parecem relevantes. No caso do setor público seria necessário, para começar, ter dados sobre os níveis de escolaridade dos funcionários (que podem afetar suas orientações valorativas e políticas), sobre os sistemas de admissão (mais clientelísticos ou mais racionalizados), sobre a existência ou não de organizações sindicais capazes de atuação relativamente autônoma ante as elites locais etc.

O exame das diferenças regionais nas composições socioprofissionais das bancadas dos Estados mostrou um quadro complexo que não é 
diretamente dedutível dos níveis de desenvolvimento econômicos e de "modernização" locais. Os Estados têm histórias políticas singulares. Mas, sem esquecer os desdobramentos que vêm dos azares da vida política, das rivalidades entre chefias locais que afetam a composição das cúpulas particulturais de cada meio que levam a determinadas composições das bancadas e não o contrário. Essa linha de causação não exclui que elites políticas busquem preservar, na medida do possível, o contexto social e econômico que favorece sua permanência no poder. Podem ser, como já foi estudado, obstáculos para a mudança. Nesse caso, funcionariam como variáveis independentes.

Esta pesquisa, porém, não oferece elementos para a investigação desses aspectos. Para isso, as correlações partidárias deveriam ser buscadas com as características de cada Estado, ou seja, com as arenas estaduais nas quais são eleitos os parlamentares para a $\mathrm{CD}$. Mas isso não foi feito. $\mathrm{O}$ capítulo focalizou apenas as distribuições das profissões/ocupações dos partidos em relação às regiões e Estados, tal como elas emergem da composição das bancadas no seu conjunto.

\section{FORMATOS PARTIDÁRIOS REGIONAIS}

Este capítulo descreve os formatos partidários que resultaram das eleições de 1998 para a Câmara dos Deputados e mostra a evolução dos partidos e blocos ideológicos nas cinco grandes regiões e subsistemas estaduais nas eleições de 1990, 1994 e $1998 .{ }^{1}$ O exame revelou forte discrepância na força dos partidos nas regiões e unidades da Federação. Esquenzaticamente, a conclusão é de relativa estabilidade do sistema partidário com algumas mudanças que indicam continuidade de tendências anteriores. A principal delas parece ser o declínio do PMDB e, mais ainda, a do PDT De algum modo, o capítulo afastou- se da temática central do livro mas sua inclusão pareceu necessária para dar uma visão do desempenho dos partidos na $\mathrm{CD}$, locus da pesquisa.

\section{Os partidos nas grandes regiões ${ }^{2}$}

Embora seja possível detectar elementos de similitude nos grupos de Estados de cada região, uma análise mais detida das unidades da Federação que as compõem expõe facetas singulares que precisam ser examinadas por Estado. Ocorre, como já se enfatizou, que cada região, em termos de suas unidades componentes, apresenta muitas semelhanças e muitos desníveis. No Norte, do ponto de vista geopolítico, destacam-se, por um lado, dois Estados de enorme extensão territorial e mais antigos administrativamente (Amazonas e Pará) e, de outro, o conjunto de Estados pequenos (do ponto de vista de sua população) e de criação mais recente. No Nordeste, Bahia, Ceará e Pernambuco, pela dimensão populacional e pelo nível de desenvolvimento, diferenciam-se das demais pequenas unidades federativas da região. No Sudeste, o Espírito Santo separa-se dos três grandes (SP, MG e RJ) em razão da baixa dimensão do corpo eleitoral e da magnitude do

${ }^{1}$ Seguimos a classificação do IBGE com relação à divisão regional do País e aos Estados incluídos nas áreas denominadas "grandes regiões". O Estado do Tocantins, que poderia geograficamente ser colocado no Centro-Oeste, é incluído na região Norte; o Maranhão, que se encontra ao norte de Tocantins, está no Nordeste.

${ }^{2}$ Neste capítulo, uma vez que o foco de interesse não é a composição social mas os formatos partidários, introduzimos nas tabelas os dados de outras legendas que estão agregadas na rubrica "outros partidos". Quando necessário, alguma informação sobre esse grupo foi fornecida. 
colégio. Os outros Estados da região, por sua vez, aproximam-se pelo fato de possuírem grande corpo eleitoral e magnitudes elevadas e, do ângulo econômico, pelos níveis mais altos de desenvolvimento; porém, têm tradições políticas diferentes. No Sul, Paraná, Santa Catarina e Rio Grande do Sul são três casos de cultura e realidade políticas fortemente diferenciadas. No Centro-Oeste, a participação do Distrito Federal no grupo introduz uma unidade com características muito discrepantes das outras.

Com essas observações, vejamos inicialmente a distribuição das forças partidárias em cada região. $\mathrm{O}$ aspecto que mais chama a atenção, quando se focaliza a força regional de cada partido, medida pela proporção de cadeiras obtidas em cada região, é a preponderância do PFL no Nordeste. Daí vieram cerca de $45 \%$ dos parlamentares peefelistas. No Sudeste, o desequilíbrio na força dos partidos não foi tão forte: PPB, PDT, PSDB e PT têm, nas suas bancadas, mais de $40 \%$ das cadeiras obtidas nas unidades da região. No Sul, PDT e PPB foram favorecidos. Por fim, no Centro- Oeste, região de baixa magnitude eleitoral, o PMDB obteve os melhores resultados. O PDT, aí, não ganhou nenhuma cadeira.

Tabela 22

Proporção de cadeiras obtidas pelos partidos em cada região (\%)

\begin{tabular}{|c|c|c|c|c|c|c|c|c|}
\hline \multirow[b]{2}{*}{ Regiões } & \multicolumn{6}{|c|}{ Partidos } & \multirow{2}{*}{$\begin{array}{c}\text { Outros } \\
\text { partidos }\end{array}$} & \multirow{2}{*}{$\begin{array}{c}\text { Total } \\
\text { na } \\
\text { CD }\end{array}$} \\
\hline & PPB & PFL & PMDB & PSDB & PDT & PT & & \\
\hline Norte & 15,0 & 16,2 & 12,0 & 13,3 & 16,0 & 8,5 & 8,5 & 12,7 \\
\hline Nordeste & 11,7 & 44,7 & 34,9 & 27,3 & 8,0 & 16,9 & 35,4 & 29,4 \\
\hline Sudeste & 43,3 & 24,8 & 20,5 & 43,4 & 48,0 & 44,2 & 35,4 & 34,9 \\
\hline Sul & 23,3 & 9,5 & 18,1 & 8,0 & 28,0 & 11,9 & 12,2 & 15,0 \\
\hline $\begin{array}{l}\text { Centro- } \\
\text { Oeste }\end{array}$ & 6,7 & 4,8 & 14,5 & 8,0 & 0 & 8,5 & 8,5 & 8,0 \\
\hline Total & 100,0 & 100,0 & 100,0 & 100,0 & 100,0 & 100,0 & 100,0 & 100,0 \\
\hline $\mathrm{N}$ & 60 & 105 & 83 & 99 & 25 & 59 & 82 & 513 \\
\hline
\end{tabular}

Os dados da tabela 22 indicam as fortes desigualdades na penetração relativa dos partidos nas regiões. A partir daí, considerando o fato de que, na esquerda, $44 \%$ dos deputados do PT e $48 \%$ dos do PDT vieram do Sudeste; que este último partido saiu-se muito mal no Nordeste; que somente $10 \%$ das cadeiras na bancada do PFL vieram do Sul e que o Norte contribuiu com somente 9\% dos parlamentares do PT, seria tentador deduzir que a direita é forte em áreas mais atrasadas (eleitorado "menos informado" e "politizado", predominância das oligarquias locais, do coronelismo etc., são alguns dos fatores invocados) e que a esquerda e o centro saem-se melhor nas áreas mais desenvolvidas (eleitores mais informados, menor clientelismo, melhor escolarização da população são, neste caso, alguns dos fatores mais invocados).

No entanto, ao contrário do que seria de se esperar pela lógica da influência do meio circundante, PPB, PSDB, PDT e PT praticamente se igualam no Sudeste desenvolvido, isto é: um partido de direita, um de centro e dois de esquerda são fortes na mesma região. O PPB, de direita, teve fraco desempenho no Norte e especialmente no Nordeste, mas situouse em segundo lugar no Sul, logo depois do PMDB e à frente do PT enquanto o PMDB, de centro, ocupou o segundo lugar no Nordeste e ficou muito mal colocado no Sudeste.

As observações acima não devem levar à tese de que não se pode extrair nenhuma correlação entre a força dos partidos e outras variáveis de natureza socioeconômica indicativas de níveis diferenciados de desenvolvimento. Na verdade, se fosse para aprofundar a avaliação dessas relações, as características regionais deveriam ser desagregadas em muitas outras variáveis ambientais e correlacionadas com resultados de diversas eleições, além de controlar muitos e muitos outros fatores intervenientes.

Apesar dessas ressalvas, parece que, com alguma prudência, pelo menos duas indicações gerais podem ser extraídas da tabela anterior: 1) os partidos mais à direita tendem a obter melhores resultados nas regiões menos desenvolvidas; 2) os partidos de centro e de esquerda tendem a conseguir melhores resultados nas regiões mais desenvolvidas, especialmente no Sudeste. As evidências mais salientes dessas duas tendências são, por um lado, as elevadas proporções de deputados do Nordeste e do Norte que se elegeram sob a legenda do PFL e, de outro, os bons resultados do PT, PDT e PSDB, no Sudeste. São apenas tendências gerais, que encontram exceção (mas não desmentido) na alta proporção, como já foi notada, de parlamentares do PPB vindos do Sudeste e do Sul e pelo grande número de membros da bancada do PMDB que foram eleitos no Nordeste. 
Para avançar no exame do desempenho dos partidos por região ou, mais precisamente, do espaço que os deputados de cada região têm nas bancadas federais, é necessário controlar as deformações trazidas pelas dimensões das magnitudes eleitorais dos distritos estaduais, quero dizer, do número de cadeiras de cada unidade da Federação na $\mathrm{CD}$. São precisamente as diferenças na magnitude das representações estaduais que fazem com que, do ângulo da influência dos partidos na Câmara dos Deputados (e na política nacional), seja melhor obter melhores resultados nas circunscrições de alta magnitude eleitoral do que nas de baixa. ${ }^{3}$

Para avaliar a dimensão da influência regional dos partidos, o viés decorrente das diferenças das magnitudes das circunscrições pode ser eliminado pela utilização de outra metodologia. Pode-se comparar a proporção de cadeiras obtidas pelos partidos nas regiões com a proporção de cadeiras a que cada região tem na $\mathrm{CD}$. $\mathrm{O}$ resultado da divisão em que o dividendo é a porcentagem de cadeiras nos distritos eleitorais (regiões, no caso) e, o divisor, a porcentagem de cadeiras das regiões na CD, permite avaliar quanto cada partido é favorecido ou prejudicado pelos resultados de seu desempenho. Isso significa o quanto cada resultado regional aumenta ou diminui a proporção de cadeiras da legenda na $\mathrm{CD}$. O resultado superior a um indica sobrerrepresentação; o inferior a um indica sub-representação e o igual a um indica situação de equilíbrio: o partido, neste caso, obteve na circunscrição a mesma porcentagem de cadeiras que a região tem na CD. Usando esse cálculo, vejamos as dimensões das representações partidárias nas regiões.

No Norte, PFL $(2,1)$, PSDB $(1,6), \operatorname{PMDB}(1,2)$ e PPB $(1,1)$ estão sobrerrepresentados, quero dizer, alcançaram porcentagens maiores de cadeiras nessa região do que a porcentagem da região na Câmara. O PT e o PDT foram muito mal, com 0,6 e 0,5 respectivamente.

No Nordeste, apenas o PFL está ligeiramente sobrerrepresentado, com índice de 1,1. Os demais partidos estão todos sub-representados, embora a sub-representação dos partidos de esquerda seja mais acentuada

\footnotetext{
${ }^{3}$ Como notou Olavo Brasil de Lima Jr. de modo mais radical: "a interação, definida pelo texto constitucional brasileiro, entre a Federação e o sistema representativo, constitui a chave mais importante para explicar a fragmentação do sistema congressual brasileiro" (Lima Jr., 1997, p. 11).
}

do que a sofrida pelos partidos de centro: o PT e o PDT apresentaram índices de 0,2 e 0,1, respectivamente, enquanto o PMDB e o PSDB chegaram a 0,7 e a 0,6 .

No Sudeste, não há nenhum partido sobrerrepresentado. O PSDB $(0,7)$ é o partido que mais se aproxima de uma representação equilibrada. $\mathrm{O}$ PDT $(0,2)$ e o PMDB $(0,3)$ são os mais sub-representados.

No Sul, o PMDB $(1,3)$, o PPB $(1,2)$ e o PT $(1,1)$ estão sobrerrepresentados. Nessa região, o PFL $(0,9)$ está ligeiramente subrepresentado. O PDT $(0,6)$, ainda mais. O PSDB permaneceu com mesmo índice do Sudeste $(0,7)$.

O Centro-Oeste constitui um caso de certa forma singular porque os traços discrepantes são bem mais salientes do que os encontrados nas outras grandes regiões. Assim, o PDT aí não elegeu nenhum deputado. O PMDB foi o que, de longe, obteve o melhor resultado $(3,7)$, tanto na comparação com os índices que conseguiu em outras regiões como em comparação com os de outras legendas dentro do próprio Centro-Oeste. Após o PMDB, o PSDB é o segundo de melhor realização: 2,4; seguem-se o PFL e o PT, ambos com 1,5 , e depois o PPB $(1,2){ }^{4}$

Os números da tabela 23 servem somente como indicadores de sobrerrepresentação ou sub-representação. Ainda que sobrerrepresentado num dado distrito eleitoral, no caso, numa região, o partido, aí, pode não ter tido bons resultados em contraste com outros partidos. A sobrerrepresentação viria do fato de que esse partido também teria uma proporção muito pequena de cadeiras na CD.

\footnotetext{
4 Devo ao colega e amigo Fernando Limongi a sugestão para esses cálculos de sobrerrepresentação e sub-representação. Contudo, eventuais erros na realização dos cálculos são de minha exclusiva responsabilidade.
} 
Tabela 23

Índices de representação dos partidos nas regiões

\begin{tabular}{l|c|c|c|c|c|c|c}
\multirow{2}{*}{ Regiões } & \multicolumn{7}{|c}{ Partidos } \\
\cline { 2 - 8 } & PPB & PFL & PMDB & PSDB & PDT & PT & Outros \\
\hline Norte & 1,1 & 2,1 & 1,2 & 1,6 & 0,5 & 0,6 & 0,8 \\
\hline Nordeste & 0,2 & 1,1 & 0,7 & 0,6 & 0,1 & 0,2 & 0,7 \\
\hline Sudeste & 0,4 & 0,4 & 0,3 & 0,7 & 0,2 & 0,4 & 0,5 \\
\hline Sul & 1,2 & 0,9 & 1,3 & 0,7 & 0,6 & 1,1 & 0,9 \\
\hline $\begin{array}{l}\text { Centro- } \\
\text { Oeste }\end{array}$ & 1,2 & 1,5 & 3,7 & 2,4 & 0 & 1,5 & 2,1
\end{tabular}

Resultados dos partidos nas regiões

Outra maneira de medir a influência relativa dos partidos em cada região (considerada como uma circunscrição, distrito ou colégio eleitoral) é verificar não qual a proporção de deputados de uma região no total da bancada partidária (como foi feito na tabela 22), mas a proporção de deputados obtida por cada partido no total da região. Visto desse ângulo, a força do PFL no Norte e no Nordeste diminui embora não o derrube da posição de primeiro partido.

No Norte, na distribuição das 65 cadeiras que a região dispõe na CD, o PFL conseguiu 26\%. O PPB, o outro partido da direita, obteve somente $14 \%$, bem abaixo do PFL. O PSDB ficou em segundo lugar, com 20\%, seguido pelo PMDB com $15 \%$. Os dois partidos de esquerda tiveram péssimos resultados, notadamente o PDT, que só conseguiu $6 \%$ e o PT, muito sub-representado na região, ficou com 8\%. A análise combinada desses dois indicadores mostra a dificuldade do principal partido de esquerda brasileira de alcançar, no Norte, bons resultados para a Câmara (tabela 24).

No Nordeste, das 151 cadeiras em disputa, 31\% foram para o PFL e à considerável distância ficaram o PMDB e o PSDB. Mesmo assim, em termos do total de parlamentares eleitos no Nordeste, os do PFL (que tem $45 \%$ de sua bancada formada por parlamentares eleitos por Estados da região, lembremos) não alcançam um terço do total regional. O PMDB chegou em segundo, mas muito próximo do PSDB; o PPB ficou abaixo de $5 \%$ e o PDT só elegeu dois parlamentares (1,3\% do total).
Tabela 24

Cadeiras obtidas pelos partidos por região (\%)

\begin{tabular}{l|c|c|c|c|c|c}
\multirow{2}{*}{ Partidos } & \multicolumn{7}{|c}{ Regiões } \\
\cline { 2 - 7 } PFL & $\mathrm{N}$ & $\mathrm{NE}$ & $\mathrm{SE}$ & $\mathrm{S}$ & $\mathrm{CO}$ & Total na CD \\
\hline PPB & 26,2 & 31,1 & 14,5 & 13,0 & 12,2 & 20,5 \\
\hline PMDB & 13,8 & 4,6 & 14,5 & 18,1 & 9,8 & 11,7 \\
\hline PSDB & 15,3 & 19,2 & 9,5 & 19,5 & 29,2 & 16,2 \\
\hline PDT & 6,2 & 1,3 & 6,7 & 9,1 & 0 & 4,9 \\
\hline PT & 7,7 & 6,6 & 14,5 & 16,9 & 12,2 & 11,5 \\
\hline Outros & 10,8 & 19,3 & 16,2 & 13,0 & 17,1 & 15,9 \\
\hline Total & 100,0 & 100,0 & 100,0 & 100,0 & 100,0 & 100,0 \\
\hline N & 65 & 151 & 179 & 77 & 41 & 513
\end{tabular}

Uma avaliação geral da força dos partidos

A análise combinada dos três enfoques anteriores permite uma avaliação mais segura sobre a representatividade dos partidos nas cinco grandes regiões. No Norte e Nordeste, qualquer que seja o ângulo de abordagem, a posição predominante do PFL não é abalada. PMDB e PSDB, nessas duas regiões, estão emparelhados, depois do PFL. Os dois partidos de esquerda, especialmente o PDT, tiveram aí maus resultados. Foram acompanhados pelo PPB, o que faz do PFL o único partido de direita relevante nas duas regiões. O PMDB e o PSDB disputam as posições de centro, com ligeira vantagem para os tucanos.

No Sudeste, o PSDB é o principal partido, relativamente distanciado dos demais. Esse partido ficou com cerca de um quarto das cadeiras que cabem à região na $\mathrm{CD}$. $\mathrm{O}$ voto de direita repartiu-se de modo equitativo entre o PFL e o PPB, dando a cada um deles 26 cadeiras. Na esquerda, as preferências foram para o PT que elegeu mais do dobro dos parlamentares que o PDT no conjunto da região: 26 contra 12. O PMDB ficou somente com dezessete cadeiras $(10 \%)$ 
No Sul, o PMDB, com $20 \%$ dos lugares, é o primeiro partido, seguido do PPB (18\%) e do PT (17\%). O PSDB (10\%) ficou atrás do PFL (13\%). O PDT, entre os partidos que estamos examinando, acabou em último lugar $(9 \%)$.

Nos Estados do Centro-Oeste, o PMDB e o PSDB alcançaram ótimos resultados, ficando ambos com quase a metade dos 41 deputados a que a região tem direito. O PMDB ganhou doze cadeiras e o PSDB, oito. O PFL e o PT conseguiram, cada um, cinco parlamentares. O PDT não elegeu ninguém.

\section{A distribuição de força nos estados}

A comparação entre as regiões oferece uma primeira visão geral da força regional dos partidos, mas requer uma segunda análise mais detalhada. Os perfis partidários não são iguais no interior das unidades da Federação que compõem cada grande região. São os Estados que constituem os colégios eleitorais que formam a arena no interior da qual se travam as disputas pelas cadeiras na CD (e outras instâncias), sendo os governadores uma das peçaschave para os resultados das disputas políticas, como mostrou Abrucio (1998) em sua análise do papel dos governadores na transição para a democracia.

Os Estados do Norte - No caso dessa região, parece ser necessária uma separação do bloco dos novos Estados (ex-territórios), de um lado, do bloco dos Estados mais antigos, Amazonas e Pará, de outro. No Norte Novo (quarenta cadeiras), o PFL e o PSDB elegeram, respectivamente, dez e oito deputados. O PPB e o PMDB vieram a seguir com sete e seis cadeiras. Os partidos de esquerda tiveram maus resultados: o PDT fez três parlamentares e o PT, dois. Para a má performance dos dois partidos de esquerda, a "contribuição" do Tocantins, do Amapá e de Roraima foi especialmente relevante porque nem o PT nem o PDT conseguiram qualquer cadeira nesses colégios.

No Norte Antigo (Amazonas e Pará), os resultados de 1998 também não foram bons para os dois partidos de esquerda, em especial para o PDT que só elegeu um deputado (no Pará). O PFL continuou como o principal partido da sub-região, com $28 \%$ das 25 cadeiras em disputa. Mas, aqui, o PPB teve resultados inferiores aos dos Norte Antigo: dos nove deputados eleitos por essa legenda na região Norte, sete vieram do Norte Novo.
Tabela 25

Norte Novo - Cadeira por partido (n.a.)

\begin{tabular}{l|c|c|c|c|c|c|c|c}
\multirow{2}{*}{ Estado } & \multicolumn{10}{|c}{ Partido } \\
\cline { 2 - 10 } & PPB & PFL & PMDB & PSDB & PDT & PT & Outros & Total \\
\hline Acre & 1 & 3 & 1 & 0 & 1 & 2 & 0 & 8 \\
\hline Amapá & 0 & 2 & 1 & 3 & 0 & 0 & 2 & 8 \\
\hline Rondônia & 0 & 2 & 1 & 2 & 2 & 0 & 1 & 8 \\
\hline Roraima & 4 & 0 & 1 & 2 & 0 & 0 & 1 & 8 \\
\hline Tocantins & 2 & 3 & 2 & 1 & 0 & 0 & 0 & 8 \\
\hline $\mathrm{N}$ & 7 & 10 & 6 & 8 & 3 & 2 & 4 & 40
\end{tabular}

A comparação entre o bloco do Norte Novo e o do Norte Antigo não indica nenhuma diferença de relevo, a não ser a discrepância na votação do PPB nas duas sub-regiões: sete cadeiras no Norte Novo e somente duas no Norte Antigo. Nas duas sub-regiões, o PFL e o PSDB ficaram em primeiro e segundo lugares. O PT, no Norte Novo, conseguiu duas cadeiras (no Acre), mas não elegeu ninguém nos demais Estados. No Norte Antigo, o PT também malogrou no Amazonas, mas conseguiu três cadeiras no Pará.

Tabela 26

Norte Antigo - Cadeira por partido (n.a.)

\begin{tabular}{c|c|c|c|c|c|c|c|c}
\multirow{2}{*}{ Estado } & \multicolumn{7}{|c}{ Partido } \\
\cline { 2 - 10 } & PPB & PFL & PMDB & PSDB & PDT & PT & Outros & Total \\
\hline Amazonas & 1 & 4 & 0 & 1 & 0 & 0 & 2 & 8 \\
\hline Pará & 1 & 3 & 4 & 4 & 1 & 3 & 1 & 17 \\
\hline $\mathrm{N}$ & 2 & 7 & 4 & 5 & 1 & 3 & 3 & 25
\end{tabular}

Os Estados do Nordeste - Nove unidades da Federação formam a região. Desprezando, neste momento, as singularidades de cada Estado, dois blocos poderiam ser construídos: o dos grandes Estados, definido pelos colégios com magnitude acima de vinte: Bahia (39 cadeiras), Pernambuco (25) e Ceará (22) com um total de 86 parlamentares; e o dos colégios eleitorais de magnitude menor do que vinte: Maranhão (18), Paraíba (12), Piauí (10), Alagoas (9), Rio Grande do Norte (8) e Sergipe (8), num total de 65. 
No bloco dos três maiores colégios nordestinos — excluindo-se outros partidos e considerando apenas os seis que entraram na pesquisa direita e centro praticamente se equivalem, com ligeira vantagem para a direita. A esquerda, representada pelo PT e pelo PDT, ficou com apenas $9 \%$ (oito em 86) das cadeiras na CD a que o bloco "dos três grandes" teria direito. O PDT ganhou apenas uma cadeira. Do mesmo modo, na direita, os méritos vão para o PFL, com $34 \%$ dos lugares. O PPB elegeu somente quatro parlamentares nesses três colégios eleitorais somados. No centro, o PSDB superou o PMDB, especialmente em virtude dos resultados obtidos pelos tucanos no Ceará: doze deputados dos dezenove que elegeu nos três Estados. Os resultados do PMDB (onze cadeiras) estão mais bem distribuídos nesse bloco.

Do prisma ideológico, a votação conseguida pelo PSB em Pernambuco (oito deputados), único Estado brasileiro em que esse partido teve uma votação expressiva, afeta a comparação. Se as cadeiras obtidas pelo PSB fossem somadas às do PT e PDT os números para a esquerda seriam melhores. Nesse bloco dos colégios eleitorais maiores, os "outros partidos" tiveram resultado expressivo: $17 \%$ do total das cadeiras, em razão basicamente dos azares da política local e do personalismo.

Ainda no bloco dos três maiores colégios eleitorais do Nordeste, o quadro partidária mostra acentuados desníveis quanto à força dos partidos em cada um dos Estados. Na Bahia, o PFL ficou com 51\% das 39 cadeiras em disputas; o PSDB obteve apenas $15 \%$, porcentagem que não pode ser vista muito negativamente face aos resultados ainda piores das demais legendas (PPB e PDT ficaram abaixo dos 3\%). Em razão do predomínio do PFL, o índice baiano de fragmentação partidária é um dos mais baixos $(0,68)$ do País, com apenas 3,2 partidos efetivos. Essa é, na verdade, uma

\footnotetext{
${ }^{5} \mathrm{O}$ crescimento da votação socialista iniciou-se com a saída do governador Miguel Arraes do PMDB e sua adesão ao PSB. Em fevereiro de 1990, Miguel Arraes rompeu formalmente com o PMDB, candidatou-se a deputado federal nas eleições de 3 de outubro desse ano e obteve 339.197 votos. O segundo colocado, das cinco cadeiras conquistadas pelo PSB no Estado, obteve somente 23.102 votos. O quarto e quinto colocados não chegaram a quatro mil votos. Dos onze socialistas eleitos no País (2,1\% da CD), cinco o foram em Pernambuco. (Fonte: Deputados Brasileiros. Repertório Biográfico, 49 Legislatura, 1991-1995. Brasília, Câmara dos Deputados, 1991.).
}

situação que caracteriza também outros Estados nordestinos nos quais apenas um partido domina o cenário político. ${ }^{6}$

No Ceará, mutatis mutandis, o PSDB ocupa posição equivalente à do PFL na Bahia. Das 22 cadeiras desse colégio, 55\% foram para os tucanos. $\mathrm{O}$ PFL não foi além dos 5\%. O PMDB ficou em segundo lugar, conseguindo $23 \%$ das cadeiras, proporção que pode ser considerada razoável face aos péssimos resultados das outras legendas, nenhuma das quais elegeu mais de um deputado. Diante do predomínio tucano no Ceará, o índice de partidos efetivos (2,7) é ainda mais baixo do que o da Bahia $(3,2)$, só superado pelo do Rio Grande do Norte $(2,5)$. A fragmentação partidária ficou em 0,64 .

Em Pernambuco, o formato partidário é um pouco mais complexo, em razão especialmente da boa realização do PSB. Nesse Estado, os socialistas repartiram o primeiro lugar com o PFL, elegendo oito dos 25 deputados federais ( $32 \%$ dos deputados pernambucanos na CD). O PMDB ainda conseguiu eleger três parlamentares, mas os demais se saíram muito mal. A fragmentação partidária $(0,68)$ ficou um pouco mais alta do que a da Bahia e a do Ceará; o número de partidos efetivos foi de 4,3.

As razões das disparidades na força dos partidos nos três grandes Estados nordestinos, provavelmente, se devem em larga medida a fatores conjunturais ligados a lutas entre as elites locais, especialmente à influência dos governadores e das grandes chefias políticas: na Bahia, a figura dominante de Antônio Carlos Magalhães; no Ceará, a adesão de um grupo de grandes empresários ao PSDB, em 1981), que fez esse partido disparar; em Pernambuco, a passagem de Miguel Arraes para o PSB, fato que enfraqueceu substancialmente o PMDB que até então era o primeiro partido. No final, em cada Estado desse grupo, os campos ideológicos tenderam a ser ocupados por apenas um partido que ficou como dono do pedaço ideológico. Nos três estados, PPB, à direita, e PDT, à esquerda, foram amplamente batidos pelo PFL e pelo PT nos respectivos campos ideológicos. No centro, a supremacia do PSDB sobre o PMDB não foi tão ${ }^{6}$ Aparentemente, a julgar pelos resultados pretéritos, a divisão ideológica, na Bahia,
encontra-se estabilizada a partir das eleições de 1990 , com a direita oscilando em torno de
$50 \%$ das cadeiras na CD. Em 1998 , a direita ficou com $56 \%$, o centro com $26 \%$ e, a
esquerda, com 18\%. Para uma análise mais detalhada da evolução do quadro partidário baiano entre as eleições de 1982 e 1994, cf. Camargos \& Cardoso (1997). 
acentuada, mas mesmo assim a diferença entre eles, nos três Estados nordestinos, foi forte e a favor dos tucanos (dezenove cadeiras para o PSDB contra onze para o PMDB).

Tabela 27

Região Nordeste- Maiores colégios - Cadeiras por partido (n.a.)

\begin{tabular}{c|c|c|c|c|c|c|c|c}
\multirow{2}{*}{ Estados } & \multicolumn{7}{|c}{ Partidos } \\
\cline { 2 - 10 } & PPB & PFL & PMDB & PSDB & PDT & PT & Outros & Total \\
\hline Bahia & 1 & 20 & 3 & 6 & 1 & 5 & 3 & 39 \\
\hline Pernambuco & 2 & 8 & 3 & 1 & 0 & 1 & 10 & 25 \\
\hline Ceará & 1 & 1 & 5 & 12 & 0 & 1 & 2 & 22 \\
\hline N & 4 & 29 & 11 & 19 & 1 & 7 & 15 & 86
\end{tabular}

O Nordeste dos pequenos estados

O bloco dos colégios estaduais de baixa magnitude eleitoral tende a reproduzir algumas das tendências na distribuição de forças partidárias existentes entre os grandes Estados do Nordeste. Também, nesse bloco, o PPB, o PT e notadamente o PDT obtiveram resultados medíocres. O PFL e o PMDB ocupam o primeiro lugar, com aproximadamente $28 \%$ do total das 65 cadeiras que o bloco dos Estados de baixa magnitude possui na CD. $\mathrm{O}$ PSDB, bem distanciado, vem em segundo lugar, com 12\%. A proporção elevada de cadeiras obtidas pelo PFL deveu-se basicamente aos resultados do Maranhão e aos do Piauí (seis e cinco cadeiras, respectivamente). Já o PMDB saiu-se melhor na Paraíba e no Rio Grande do Norte. O PT ainda conseguiu três cadeiras nesse bloco e o PDT só obteve uma (no Maranhão).

Ao contrário do que acontece na Bahia e no Ceará, a elevada proporção de votos dados às legendas que não fizeram parte da pesquisa (aqui incluídas na rubrica "outros") impede a existência de um partido hegemônico no conjunto dos Estados nordestinos de baixa magnitude eleitoral. O grupo de partidos na rubrica "outros" - na qual estão o PTB e os pequenos e micropartidos de todas as tonalidades ideológicas -

${ }^{7}$ Para mais informações sobre os Estados da Bahia e Ceará cf., respectivamente, Camargos \& Cardoso (1997) e Moraes Filho (1997) conseguiu mais de um quinto das cadeiras. Em Alagoas, por exemplo, das nove cadeiras em disputa, cinco foram para os pequenos partidos (PTB, PSB, PC do B, PSD e PMN). O fato favorece o aumento da fragmentação partidária na $\mathrm{CD}$ e aumenta a diversidade dos formatos estaduais do sistema partidário, como havia observado Olavo Brasil de Lima Jr. (Lima Jr., 1997).

Tabela 28

Região Nordeste - Pequenos colégios - Cadeiras por partido (n.a.)
\begin{tabular}{c|c|c|c|c|c|c|c}
\multirow{2}{*}{ Partidos } & \multicolumn{7}{c}{ Pequenos Colégios } \\
\cline { 2 - 8 } & AL & MA & PB & PI & RN & SE & Total \\
\hline PPB & 0 & 0 & 1 & 0 & 1 & 1 & 3 \\
\hline PFL & 1 & 6 & 3 & 5 & 3 & 0 & 18 \\
\hline PMDB & 1 & 3 & 5 & 3 & 4 & 2 & 18 \\
\hline PSDB & 2 & 3 & 1 & 1 & 0 & 1 & 8 \\
\hline PDT & 0 & 1 & 0 & 0 & 0 & 0 & 1 \\
\hline PT & 0 & 0 & 1 & 1 & 0 & 1 & 3 \\
\hline Outros & 5 & 5 & 1 & 0 & 0 & 3 & 14 \\
\hline N & 9 & 18 & 12 & 10 & 8 & 8 & 65
\end{tabular}

No conjunto da região, considerando todos os Estados e todos os partidos, a eleição de 1998 para a CD resultou em 5,5 partidos efetivos (o índice mais baixo entre todas as grandes regiões) e um índice de fragmentação de 0,82 (o mais baixo junto com o Centro-Oeste).

\section{O Sudeste}

O formato partidário do Sudeste caracteriza-se pela existência de dois grandes distritos (Minas e Rio) e um megadistrito, o Estado de São Paulo, com 24,2 milhões de eleitores, superior à soma do segundo (Minas Gerais, 12 milhões) com o terceiro (Rio, com 10 milhões). O outro distrito que compõe a região é o do Espírito Santo com somente dois milhões de eleitores. ${ }^{8}$ Tal como as demais regiões, o Sudeste é marcado por fortes discrepâncias na força dos partidos nos seus quatro colégios eleitorais.

\footnotetext{
${ }^{8}$ Dados das eleições de 1998.
} 
Na região como um todo, o PSDB, nas eleições de 1998, confirmou sua condição de principal partido. Em todos os colégios eleitorais do Sudeste, os tucanos obtiveram mais cadeiras que seus concorrentes, conquistando mais de um quinto das cadeiras em todos os Estados. O melhor resultado do partido foi no Espírito Santo. Infelizmente, para o PSDB, a magnitude da circunscrição eleitoral potiguar é pequena, de modo que 30\% de cadeiras nesse Estado significaram apenas três deputados na CD.

O PPB, o PFL e o PT seguem o PSDB como partidos com forte implantação relativa nos Estados mais desenvolvidos, o que parece positivo quanto ao seu futuro. O lado negativo da concentração no Sudeste é que essas legendas são mais dependentes dos votos ganhos nessa região. Eventuais derrotas aqui têm custos elevados porque votos perdidos para um partido são votos que beneficiam bastante os concorrentes.

As vitórias no Sudeste, para a força dos partidos na $C D$, são as que mais rendem em termos da conversão em número absoluto de cadeiras em razão das magnitudes distritais elevadas de São Paulo (70 cadeiras), Minas (53) e Rio (46). No caso do PSDB, $43 \%$ dos seus 99 deputados federais vieram do Sudeste. Outros três partidos - o PPB, o PFL e o PT empataram em segundo lugar com 26 deputados cada um, 15\% dos eleitos por cada legenda. Nesse aspecto, a diferença entre o PFL, de um lado, e o PPB e o PT, de outro, está no fato de que, nesses dois últimos, os parlamentares da região Sudeste compreendem cerca de $43-44 \%$ do total de deputados que foram para a CD sob suas legendas enquanto, para o PFL, não vão além de um quarto. $O$ fato é indicativo da menor importância relativa que, para a força do PFL, significaram os resultados nos colégios estaduais do Sudeste. ${ }^{9}$

Mas, apesar da elevada proporção de deputados do PFL eleitos pelos Estados do Nordeste, os bons resultados que esse partido conseguiu no Sudeste vão contra o senso comum de que o PFL é um partido "fundamentalmente nordestino". No Rio de Janeiro, o PFL foi superado apenas pelo PSDB, elegendo mais deputados do que cada um dos dois

\footnotetext{
${ }^{9}$ Como já mostrou Jairo Nicolau, o PFL e o PDT são partidos com altas taxas de concentração estadual (Nicolau, 1996, cap. 5, "Distribuição dos Votos e Fragmentação Parlamentar").
}

partidos de esquerda e do que o PPB. Em Minas, o PFL elegeu oito parlamentares ficando atrás apenas do PSDB (catorze) e do PMDB (nove).

No campo da esquerda, o formato partidário do Sudeste reproduz, com sinais trocados, alguns traços encontrados no Nordeste. As posições associadas à esquerda ficam cada vez mais representadas pelo PT, que nesse campo ideológico tem liderança equivalente à do PFL no campo da direita no Nordeste. O espaço que sobrou para o PDT é pequeno, tal como aconteceu com o PPB no Nordeste com relação ao campo da esquerda. Na verdade, no Rio, o PDT não chegou a ter um mau resultado: elegeu sete deputados (15\% do total do Estado), o melhor índice obtido por ele em todo o País. ${ }^{10}$ Entretanto, foi superado pelo PFL nos quatro Estados da região, inclusive no Rio que fora uma das praças-fortes do pedetismo. Entre os quatro Estados, foi em Minas que o PDT obteve seu pior resultado, conseguindo só uma cadeira num total de 53.

O PMDB, no conjunto da região Sudeste, ficou em quarto lugar, com dezessete cadeiras representando $10 \%$ do total, mas muito distante das 43 do PSDB e das do PPB e do PT, com 26 cada. Na comparação da realização dos seis partidos, vê-se que o PMDB superou apenas o PDT (doze cadeiras).

Quadro 7

Região Sudeste - Cadeiras obtidas na região (\%)

\begin{tabular}{|l|c|}
\hline Partidos & $\%$ \\
\hline PPB & 14,5 \\
\hline PFL & 14,5 \\
\hline PSDB & 24,0 \\
\hline PMDB & 9,5 \\
\hline PDT & 6,7 \\
\hline PT & 14,5 \\
\hline Outros & 16,2 \\
\hline Total & 100,0 \\
\hline
\end{tabular}

O desempenho de todos os partidos no Sudeste indica fragmentação partidária acentuada na região, sem que nenhuma legenda ocupe posição

${ }^{10}$ Em termos percentuais de parlamentares eleitos por Estado, em Roraima, o PDT chegou a $25 \%$, mas essa porcentagem representa apenas dois parlamentares na CD em razão da baixa magnitude dessa circunscrição: oito cadeiras. 
hegemônica. O PSDB, o mais forte, não teve mais do que $25 \%$ das cadeiras. De fato, as eleições de 1998 não alteraram o formato partidário regional que vinha se fixando depois de 1990: multipartidarismo com cinco a seis partidos efetivos, crescimento dos partidos médios, inexistência de um partido dominante em qualquer dos quatro distritos eleitorais, fortes desníveis na penetração dos partidos em cada Estado. ${ }^{11}$

A avaliação do desempenho dos seis partidos pelos quatro Estados do Sudeste indica que foi em São Paulo que o PMDB mais perdeu espaço. Nas eleições de 1990 e 1994, havia se mantido em torno de $20 \%$ das cadeiras em disputa. Nas de 1998, foi para menos de $10 \%$.

Tabela 29

Região Sudeste - Distribuição das cadeiras por Estado (\%)

\begin{tabular}{c|c|c|c|c} 
Partidos & SP & MG & RJ & ES \\
\hline PPB & 17,2 & 13,2 & 13,0 & 10,0 \\
\hline PFL & 11,4 & 15,1 & 19,6 & 10,0 \\
\hline PMDB & 7,0 & 17,0 & 4,3 & 10,0 \\
\hline PSDB & 21,5 & 26,4 & 24,0 & 30,0 \\
\hline PDT & 5,7 & 1,9 & 15,2 & - \\
\hline PT & 20,1 & 13,2 & 8,7 & 10,0 \\
\hline Outros & 17,1 & 13,2 & 15,2 & 30,0 \\
\hline Total & 100,0 & 100,0 & 100,0 & 100,0 \\
\hline N & 70 & 53 & 46 & 10
\end{tabular}

A ascenção do PFL é um dos traços mais marcantes no mapa político paulista. Esse partido que tinha conseguido eleger apenas um deputado federal em 1990, elegeu três em 1994 e pulou para oito na atual legislatura. Em termos percentuais, os resultados foram, respectivamente, 1,7\%; 4,3\% e $11 \%$. No entanto, apesar da ascensão do PFL e do pequeno avanço (cerca de $2 \%$ ) dos pequenos partidos de esquerda (PSB, PC do B, PPS), o formato partidário de São Paulo vem se mostrando relativamente estável. A fragmentação partidária, na $\mathrm{CD}$, ficou em 0,85 . O número de partidos efetivos foi 6,9 (contra 6,70 e 6,66 em 1990 e 1994, respectivamente),

\footnotetext{
${ }^{11}$ Baseio-me aqui em meus dados sobre as eleições de 1998 e nos seguintes estudos sobre a evolução partidária no Sudeste (1982-1994): Figueiredo e Jorge (1997), Lamounier (1997), Schmitt (1997) e Nicolau (1996).
}

índice que coloca São Paulo no grupo dos seis Estados com mais elevado número de partidos parlamentares relevantes.

Das quatro circunscrições estaduais do Sudeste, Minas e Rio também possuem mais de seis partidos efetivos. Apenas o Espírito Santo tem um número relativamente baixo $(4,5)$. Como é intuitivo, o fato indica que, se todos os demais fatores forem iguais, as circunscrições eleitorais com magnitudes maiores tendem a favorecer o multipartidarismo, uma vez que o número de partidos parlamentares não pode ultrapassar o número da magnitude que serve, assim, de teto. Mas o número de partidos parlamentares dificilmente alcança a dimensão da magnitude. Por isso, magnitudes baixas tendem a reduzir o número de partidos parlamentares. Como observa Jairo Nicolau "o sistema eleitoral brasileiro [multipartidário] é composto por mecanismos que favorecem os maiores partidos, muito embora a alta magnitude de alguns distritos tenda a tornar mais fácil a representação dos menores partidos" (Nicolau, 1996, p. 61). O autor tem razão, mas convém apontar a grande exceção de Alagoas que, em 1998, com somente nove cadeiras na CD, apresentou um índice de 7,3 partidos efetivos e um índice de fragmentação de 0,86 , considerado bem elevado pelos especialistas. ${ }^{12}$

\section{A região Sul}

Das cinco grandes regiões brasileiras, o Sul é a mais simples do prisma do número de colégios eleitorais. Três Estados, dois com magnitude média e um de baixa magnitude: Rio Grande do Sul, com 31 deputados; Paraná, com trinta e Santa Catarina, com dezesseis. Apesar de alguns elementos de similitude da região como um todo, politicamente há muitas diferenças entre as três unidades da Federação que têm histórias partidárias diversas.

A análise do formato partidário do Sul mostra novamente o peso dos fatores regionais (e estaduais, como se verá) no sistema eleitoral brasileiro, quero dizer, a dificuldade para os partidos superarem as barreiras regionais na direção da construção de organizações com penetração nacional

12 Além do PSDB (dois deputados), do PFL (um) e do PMDB (um), os seguintes partidos também ganharam um representante: PTB, PSB, PPS, PSD, PMN. 
relativamente equilibrada na maioria dos colégios estaduais. O PSDB, por exemplo, que teve bons resultados no Sudeste, foi muito mal no Sul, embora as duas regiões pudessem ser consideradas como partes do "Brasil moderno". Com apenas 10\% das 77 cadeiras da região, entre os seis partidos da pesquisa, os tucanos ficaram à frente apenas do PDT. O primeiro lugar coube ao PMDB (20\%), seguido do PPB (18\%), PT (17\%) e PFL (13\%).

Contudo, apesar de o PMDB conservar a primeira posição, houve pequeno recuo dessa legenda no Sul: dezessete deputados em 1994 para quinze em 1998. Quanto às eleições passadas, o PFL permaneceu estável: dez deputados nas duas disputas. O PT teve, nas mesmas eleições, ganho de uma cadeira e o PDT perdeu três, caindo de dez para sete. No conjunto da região, o PPB saiu-se bem em 1998, ficando em segundo lugar, logo abaixo do PMDB.

Quadro 8

Região Sul — Cadeiras obtidas por partido (\%)

\begin{tabular}{|c|c|}
\hline Partidos & $\%$ \\
\hline PPB & 18,1 \\
\hline PFL & 13,0 \\
\hline PMDB & 19,5 \\
\hline PSDB & 10,4 \\
\hline PDT & 9,1 \\
\hline PT & 16,9 \\
\hline Outros & 13,0 \\
\hline Total & 100,0 \\
\hline
\end{tabular}

\section{Os resultados nos Estados}

Focalizando agora os Estados sulistas individualmente, vemos que se repetem as discrepâncias observadas nas outras grandes regiões. No Rio Grande do Sul, o PFL obteve um resultado medíocre, elegendo apenas um deputado. O PT, que ficou com oito das 31 cadeiras que cabem ao Rio Grande do Sul na CD, elegeu apenas dois parlamentares em Santa Catarina. O Partido dos Trabalhadores também colheu maus resultados no Paraná (10\% do total de cadeiras do Estado), só superado, nesse aspecto, pelo PDT (que naufragou também em Santa Catarina). Os tucanos, por sua vez, conseguiram cinco das trinta cadeiras do Paraná, de longe seu melhor resultado nos Estados sulistas, logo abaixo do PFL (seis cadeiras).

De modo geral, novamente, temos um quadro de multipartidarismo na política dos Estados do Sul. Esse quadro, a juízo de alguns estudiosos dos subsistemas desses Estados, tem permanecido relativamente estável, com pequeno crescimento da esquerda nas eleições proporcionais (Tavares, 1997; Grohmann, 1997, para o RS e SC, respectivamente). O número de partidos efetivos manteve-se entre cinco e seis no Rio Grande do Sul: 5,30 em 1990; 6,00 em 1994 e 5,7 em 1998. Em Santa Catarina, em troca, o número de partidos efetivos subiu e voltou a aproximar-se do índice de 1990: 5,1 nessas últimas eleições contra 4,4 em 1994 e 5,3 em 1990. No Paraná, os números são mais elevados: 6,1 partidos efetivos em 1998 (7,0 em 1994 e 5,5, em 1990). A fragmentação no Paraná foi de 0,83, em 1998; 0,85 em 1994 e 0,82 em 1990.

Tabela 30

Região Sul — Distribuição das cadeiras por Estado (\%)

\begin{tabular}{l|c|c|c|c}
\multirow{2}{*}{ Partidos } & \multicolumn{4}{|c}{ Região Sul } \\
\cline { 2 - 5 } & PR & SC & RS & Total \\
\hline PFL & 20,0 & 18,8 & 3,2 & 10 \\
\hline PPB & 16,7 & 25,0 & 16,1 & 14 \\
\hline PMDB & 13,3 & 25,0 & 22,6 & 15 \\
\hline PSDB & 16,7 & 6,3 & 6,5 & 8 \\
\hline PDT & 3,3 & 12,5 & 12,9 & 7 \\
\hline PT & 10,0 & 12,5 & 25,8 & 13 \\
\hline Outros & 20,0 & 0 & 12,9 & 10 \\
\hline Total & $100,0 \%$ & 100,0 & 100,0 & - \\
\hline N & 30 & 16 & 31 & 77
\end{tabular}

\section{Centro-Oeste}

A grande região do Centro-Oeste, com quatro unidades federativas, mostra duas discrepâncias estruturais que podem afetar o formato partidário regional. A primeira delas diz respeito à magnitude das quatro circunscrições: Distrito Federal, Mato Grosso e Mato Grosso do Sul têm oito cadeiras na CD, a menor magnitude estabelecida pela Constituição. Já 
Goiás tem dezessete deputados. ${ }^{13}$ A segunda discrepância é de caráter socioeconômico. Trata-se da presença do Distrito Federal, com forte peso da burocracia federal, num conjunto em que as atividades pecuárias e agrícolas são importantes. O resultado, novamente, é o acentuado contraste partidário intrarregional.

Quadro 9

Região Centro-Oeste — Cadeiras por partido (\%).

\begin{tabular}{|l|c|}
\hline Partidos & $(\%)$ \\
\hline PPB & 9,8 \\
\hline PFL & 12,2 \\
\hline PMDB & 29,2 \\
\hline PSDB & 19,5 \\
\hline PDT & 0 \\
\hline PT & 12,2 \\
\hline Outros & 17,1 \\
\hline Total & 100,0 \\
\hline
\end{tabular}

Favorecido pela grande vitória em Goiás (47\% das cadeiras), o PMDB conseguiu $29 \%$ das 41 cadeiras que cabem ao Centro-Oeste. Ao PSDB, com 20\%, coube o segundo lugar. O PFL ficou junto com o PT, com $12 \%$, o equivalente a cinco representantes. O PDT não conseguiu nenhuma cadeira.

Mas os resultados do PMDB na região, além de muito desiguais nas unidades federativas, têm mostrado certa oscilação: em 1990 elegeu dez deputados; em 1994, apenas sete e em 1998 recuperou-se, portanto, da perda ocorrida no pleito de 1994.

O restante dos lugares, em Goiás, distribuiu-se entre várias legendas, fato que, por um lado, aumenta o poder do PMDB e, por outro, ajuda a baixar o índice de partidos efetivos para 3,6. O PSDB, com certa distância do PMDB, obteve a segunda posição. Nos outros Estados do Centro-Oeste

\footnotetext{
${ }^{13}$ A magnitude da representação de Goiás passou de 16 cadeiras em 1982 para 17, a partir de 1986. Para os dados que não se referem à SP Legislatura, baseamo-nos em Assis (1997) e Nicolau (1998).
}

houve relativo equilíbrio entre os partidos, se não contarmos o completo fracasso pedetista em todas as circunscrições da região (nenhum de seus candidatos foi eleito) e do fracasso do PT no Mato Grosso, onde não ganhou uma só cadeira. Em compensação, ao lado do PPB, os petistas conseguiram dois dos oito deputados do Distrito Federal, colégio em que a votação foi dispersa (tabela 31).

No geral, a baixa magnitude dos colégios do Centro-Oeste e a dispersão de votos por várias legendas (com exceção de Goiás) não influenciaram de modo significativo a força relativa dos partidos na CD.

Tabela 31

Região Centro-Oeste — Distribuição das cadeiras por Estado (\%)

\begin{tabular}{l|c|c|c|c|c} 
Partidos & DF & GO & MT & MS & Total \\
\hline PPB & 25,0 & 5,9 & 0 & 12,5 & 9,7 \\
\hline PFL & 12,5 & 11,8 & 12,5 & 12,5 & 12,5 \\
\hline PMDB & 12,5 & 47,0 & 25,0 & 12,5 & 29,1 \\
\hline PSDB & 12,5 & 11,8 & 37,5 & 25,0 & 19,4 \\
\hline PDT & 0 & 0 & 0 & 0 & 0 \\
\hline PT & 25,0 & 5,9 & 0 & 25,0 & 12,2 \\
\hline Outros & 12,5 & 17,6 & 25,0 & 12,5 & 17,1 \\
\hline N & 8 & 17 & 8 & 8 & 41
\end{tabular}

141 


\section{EM DIREÇÃO DA ESTABILIZAÇÃO?}

Avaliando comparativamente o desempenho das seis legendas ao longo de três eleições para a CD efetuadas sob a Constituição de 1988, ou seja, num contexto político de competitividade razoavelmente elevada, seis aspectos parecem mais significativos:

1) Crescimento muito forte e constante do PSDB.

2) Crescimento forte e constante do PT.

3) Crescimento pequeno e constante do PFL.

4) Declínio pequeno do PPB.

5) Declínio forte e constante do PMDB.

6) Declínio muito forte e constante do PDT.

O PPB, entre 1990 e 1998, oscilou ligeiramente; cresceu um pouco de 1990 para 1994 para depois, em 1998, sofrer uma pequena perda. ${ }^{1}$ Mas cumpre notar que a avaliação da realização do PPB é prejudicada por se tratar de um partido que resultou da fusão com outros e que só concorreu com esse nome em 1998. ${ }^{2}$ Com essa ressalva, cotejando as cadeiras ganhas pelas legendas que se fundiram para dar origem ao PPB, esse partido declinou 6\% entre 1990 e 1998.

O PFL teve um crescimento pequeno mas constante nas três eleições. $\mathrm{Na}$ realidade, em situação de normalidade institucional e política seria difícil que as porcentagens de crescimento dessa legenda fossem muito altas porque se trata de um partido que já era forte em 1990 (17\% dos lugares na CD). Percentualmente, ganhos elevados nesses casos são mais raros. ${ }^{3}$ Ainda assim, o PFL cresceu $27 \%$.

\footnotetext{
${ }^{1}$ Estamos denominando pequenos os ganhos ou perdas de cadeiras inferiores a 4\%; médios os ganhos ou perdas entre mais de $4 \%$ e $10 \%$; e elevados os ganhos ou perdas acima de $10 \%$. ${ }^{2}$ O atual PPB é fruto da fusão, em 1993/1994, do PPR com o PP. O PPR, por sua vez, resultou da fusão, em 1992, do PDS com o PDC. O PP surgiu da fusão do PTR com o PST. Para 1990 e 1994 usamos os resultados do PPR que não é exatamente o PPB de hoje. Nas eleições de 1994, o PP, como legenda própria, conseguiu 7\% das cadeiras da CD. Esses dados não foram agregados aos do PPR.

${ }^{3}$ Em 1990, o PFL conseguiu 17\% das cadeiras na CD; o PSDB , 8\% e o PT, 7\%.
}

O PMDB registrou, de modo linear, perdas elevadas entre 1990 e 1998. Entre esses anos, o PMDB declinou 23\%. (As perdas mais acentuadas desse partido foram entre as eleições de 1986 e 1990, período não analisado aqui.).

O PSDB foi a legenda que mais cresceu nas três eleições, especialmente na comparação entre 1994 e 1998. Mas já tivera forte crescimento entre 1994 e 1990. Comparando o número de cadeiras de tucanos, em 1990, com o de 1998, o aumento foi de $161 \%$.

O PDT acusa perdas médias constantes no cotejo entre as porcentagens de cadeiras que havia conseguido em 1990 e 1998. Suas perdas foram mais fortes entre 1990 e 1994. Em termos de número de cadeiras, sua bancada declinou 46\% entre 1990 e 1998.

O PT foi outro partido que cresceu constantemente ao longo do período, embora não de modo tão acentuado como o PSDB. Ainda assim, percentualmente, esse partido avançou bastante (69\%).

No exame da evolução dos seis partidos nas três últimas eleições para a $\mathrm{CD}$, vê-se que, coincidentemente, houve crescimento de cada uma das legendas de uma tendência ideológica: direita, centro e esquerda, ou seja, PFL, PSDB e PT. Os outros partidos desses mesmos campos ideológicos perderam espaço parlamentar. Esses resultados indicam que, na sedimentação do sistema partidário brasileiro, cada um dos três campos ideológicos ameaça ser ocupado por um só partido. O PDT, especialmente, se as tendências anteriores persistirem, corre o risco de se encolher ainda mais e de deixar a representação das várias posições do campo da esquerda para o PT e para outros pequenos partidos de esquerda. ${ }^{4}$

Em comparação com o PDT, mutatis mutandis, o PPB no campo da direita parece resistir melhor ao avanço do PFL, talvez porque expresse setores diferentes das classes empresariais e tenha, no Sudeste e Sul, bases mais sólidas. O PDT, ao contrário, perdeu as posições fortes que possuía no Rio e no Rio Grande do Sul e, consequentemente, encontra-se muito

\footnotetext{
${ }^{4}$ Essas conclusões baseiam-se apenas nos resultados eleitorais para a CD. Não nos interessa aqui a discussão das razões do declínio pedetista que podem decorrer da desatualização de suas propostas políticas e de outros fatores relacionados à organização interna do partido.
} 
fragilizado para se defender do avanço de outras tendências de esquerda (tabela 32).

Como vimos, o exame das regiões e dos Estados revelou formatos bastante diferenciados na distribuição de forças partidárias, fato que, por si só, favorece o aumento do número de partidos efetivos na Câmara de Deputados, quero dizer, contribui para acentuar o multipartidarismo. ${ }^{5}$ Para o exame desses formatos cumpre levar em conta os partidos que não foram incluídos no estudo sobre a composição social das bancadas. Boa parte das cadeiras, em cada região, foi para esses partidos (com exceção do PTB, pequenos e micropartidos). Assim, no Norte, a rubrica "outros" (partidos) representa $11 \%$ das cadeiras; no Nordeste, $19 \%$; no Sudeste, $16 \%$; no Sul, $13 \%$ e no Centro-Oeste, $17 \%$ (tabela 24 ).

\footnotetext{
${ }^{5}$ Olavo Brasil de Lima Jr. - na conclusão de um estudo comparativo sobre os formatos eleitorais de oito Estados da Federação (BA, CE, GO, MG, RJ, RS, SC e SP) — entende que existem dois subsistemas a caracterizar nosso multipartidarismo: um moderadamente fragmentado e, outro, altamente fragmentado (Lima Jr., 1997, p. 304). Suas conclusões baseiam-se em resultados que incluem as disputas por outros cargos eletivos. Além do número de partidos efetivos e da fragmentação partidária, apoiam-se em outros indicadores, como os cálculos dos índices de volatilidade eleitoral. O período estudado vai de 1982 a 1994. Não inclui, portanto, as eleições de 1998. Mas os índices de partidos efetivos e de fragmentação partidária que calculamos para as eleições de 1998 para a CD coincidem com suas conclusões.
}

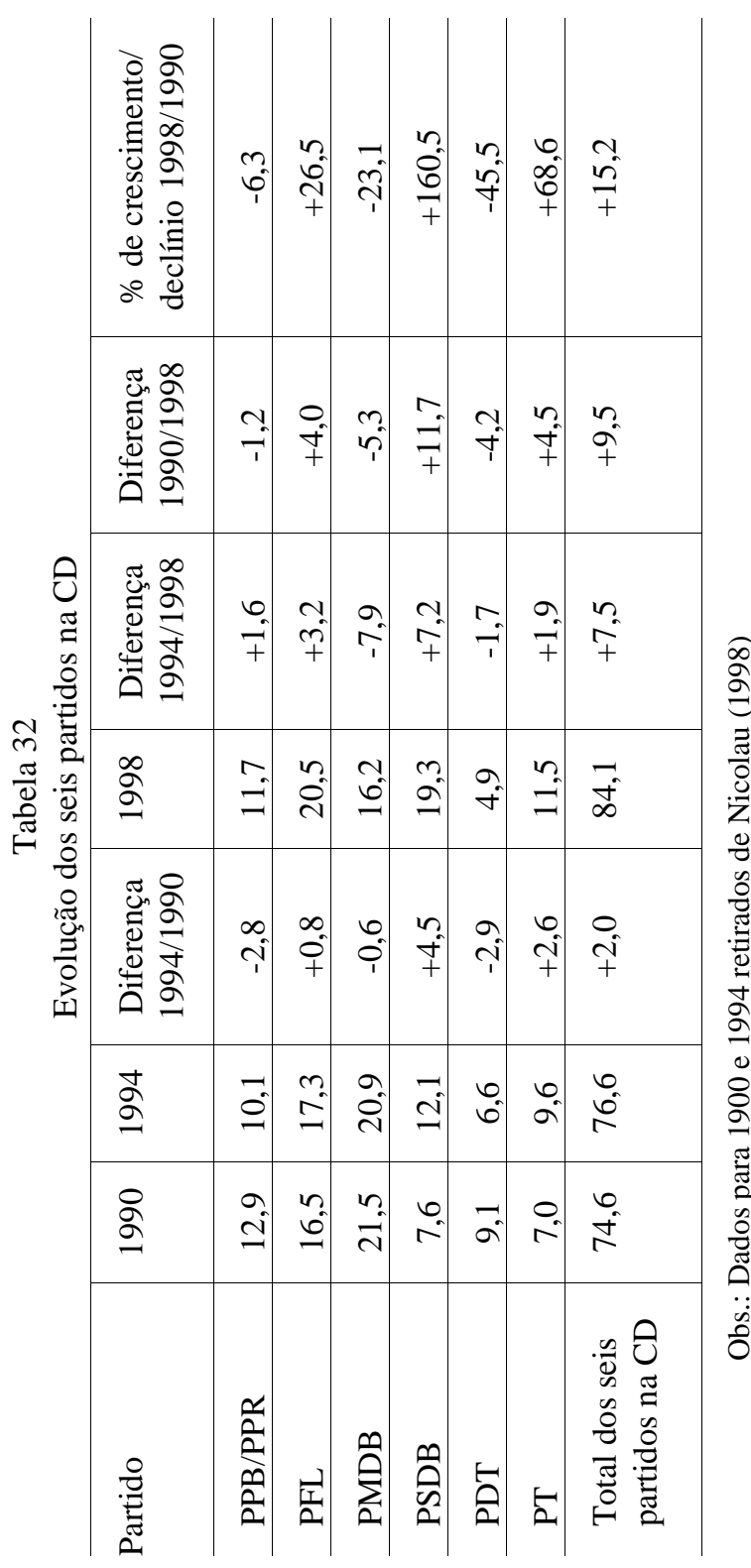




\section{As variações nas tendências ideológicas}

No total, são dezoito partidos parlamentares com, pelo menos, uma cadeira na CD. Portanto, o bloco de "outros" inclui doze partidos. Nove deles elegeram menos do que oito parlamentares (1,5\% da CD) e, quatro dessas legendas, somente um (0,2\%): Prona, PSL, PST e PV. É claro, pois, que na grande maioria das circunscrições estaduais, a maior parte dos partidos não elegeu ninguém.

$\mathrm{O}$ reduzido número de cadeiras que esses partidos possuem na $\mathrm{CD}$ não recomendava incluir, no estudo sobre as relações entre a composição socio-ocupacional dos partidos e a ideologia, legendas com um número muito pequeno de parlamentares. A "bancada" dos micropartidos se identificaria, em vários casos, com o próprio parlamentar ou com reduzido número deles. Dificilmente se poderia dizer que suas bancadas teriam alguma vinculação com segmentos da sociedade ou com correntes ideológicas e políticas expressivas do eleitorado. Assim, essas legendas foram deixadas de lado na parte da pesquisa que tratou da composição socio-ocupacional dos partidos e de suas orientações ideológicas. Mas para uma avaliação da distribuição das orientações político-programáticas no conjunto da $\mathrm{CD}$ foram considerados todos os partidos que elegeram ao menos um deputado. ${ }^{6}$

No final, a inclusão das legendas que tinham sido deixadas de lado acabou não alterando significativamente o formato ideológico que resultara da análise do grupo dos seis partidos, mesmo porque eles representavam $84 \%$ do total de parlamentares. Com essas observações, resumimos a seguir os principais aspectos que derivam do exame dos blocos ideológicos formados pelos dezoito partidos que conseguiram uma ou mais cadeiras nesta SP Legislatura:

1. O centro obteve os melhores resultados em todas as grandes regiões, mas, no Norte, empatou com a direita.

2. A esquerda ficou em último lugar em todas as regiões.

${ }^{6}$ Foram considerados partidos de direita: PFL, PPB, PL, PSD, PSC, Prona, PSL, PST; como partidos de centro: PMDB, PSDB, PTB; como partidos de esquerda: PT, PDT, PSB, PCdoB, PPS, PMN e PV. Essa classificação acompanha a da maioria dos cientistas políticos anteriormente citados.
3. Em todas as regiões, os partidos de centro obtiveram mais de $40 \%$ de parlamentares.

4. Em número de cadeiras, as diferenças entre o centro e a direita são muito pequenas no Norte e Nordeste, mas são fortes no Sul, Sudeste e Centro-Oeste, fato indicativo de maior homogeneidade ideológicopartidária nas duas primeiras regiões.

Tabela 33

Distribuição dos blocos ideológicos nas regiões e na CD (\%) (todas as legendas incluídas)

\begin{tabular}{l|c|c|c|c|c|c}
\multirow{2}{*}{ Blocos } & \multicolumn{7}{|c}{ Região } \\
\cline { 2 - 7 } & $\mathrm{N}$ & $\mathrm{NE}$ & $\mathrm{SE}$ & $\mathrm{S}$ & $\mathrm{CO}$ & Total na CD \\
\hline Direita & 41,5 & 41,1 & 33,5 & 31,2 & 31,7 & 36,1 \\
\hline Centro & 41,5 & 41,0 & 40,2 & 41,5 & 53,7 & 42,1 \\
\hline Esquerda & 17,0 & 17,9 & 26,3 & 27,3 & 14,6 & 21,8 \\
\hline Total & 100,0 & 100,0 & 100,0 & 100,0 & 100,0 & 100,0
\end{tabular}

5. Os melhores resultados da direita estão no Norte e no Nordeste; os melhores da esquerda, no Sul e no Sudeste

Em termos de cadeiras ganhas pelos partidos de cada bloco, o centro é o que tem a penetração mais equilibrada em todas as cinco grandes regiões. Com exceção do Centro-Oeste, onde obteve 54\%, em todas as outras regiões, a porcentagem de cadeiras obtidas pelos partidos de centro oscilou em cerca de $40 \%$. Não aconteceu a mesma coisa com a direita e com a esquerda. O bloco dos partidos de direita, no Norte e Nordeste, ficou em torno de $41 \%$ mas baixou para cerca de $30 \%$ nas outras (34\%, no Sudeste, e $31 \%$, no Sul). O bloco da esquerda também oscilou bastante: saiu-se mal no Norte e no Nordeste, ficando com 17-18\%. No CentroOeste, teve $15 \%$, resultado ainda pior que nas duas primeiras regiões. A esquerda foi melhor no Sul e no Sudeste, com $27 \%$ e $26 \%$, respectivamente.

Em síntese, considerando a proporção de cadeiras que os três blocos têm em cada região, vê-se que a direita teve bons resultados no Norte e no Nordeste, regulares no Sudeste e um pouco mais baixos no Sul e no CentroOeste. No total da CD, esse bloco tem $36 \%$ das cadeiras. O centro tem bons resultados nas cinco regiões, especialmente no Centro-Oeste. Na Câmara, é o bloco mais forte, com $42 \%$ das cadeiras. A esquerda teve maus resultados 
no Norte, no Nordeste e no Centro-Oeste e resultados regulares no Sudeste e no Sul. No conjunto da CD tem $22 \%$ dos lugares.

Focalizando todas as regiões, a direita está sobrerrepresentada no Norte e no Nordeste e sub-representada no Sul. O centro está em situação de quase equilíbrio em todas as regiões, com exceção do Centro-Oeste onde está sobrerrepresentado. A esquerda está sub-representada no Norte, no Nordeste e especialmente no Centro-Oeste, mas sobrerrepresentada no Sul e no Sudeste.

Tabela 34

Índices de representação dos blocos ideológicos nas regiões

\begin{tabular}{l|c|c|c|c|c}
\multirow{2}{*}{ Blocos } & \multicolumn{5}{|c}{ Região } \\
\cline { 2 - 6 } & $\mathrm{N}$ & $\mathrm{NE}$ & $\mathrm{SE}$ & $\mathrm{S}$ & $\mathrm{CO}$ \\
\hline Direita & 1,14 & 1,14 & 0,93 & 0,83 & 0,88 \\
\hline Centro & 0,99 & 0,97 & 0,95 & 0,99 & 1,3 \\
\hline Esquerda & 0,78 & 0,82 & 1,2 & 1,3 & 0,67
\end{tabular}

\section{$\mathrm{O}$ crescimento do bloco de centro}

No total da CD (todos os partidos parlamentares incluídos), a comparação com eleições passadas indica que o bloco que mais cresceu foi o dos partidos de centro. Para esse resultado contou muito o crescimento do PSDB que, de algum modo, compensou as perdas do PMDB. O melhor resultado do centro foi entre as eleições de 1990 e 1994. O bloco da direita sofre perdas fortes quando o ponto de referência é a eleição de 1990. O bloco da esquerda conseguiu crescimento pequeno entre 1990 e 1998, mas teve ligeiro recuo na comparação entre 1994 e 1998. O bloco dos partidos dessa tendência ideológica foi particularmente prejudicado pelo declínio do PDT. $^{7}$

\footnotetext{
${ }^{7}$ Um exame mais detalhado da performance dos partidos nas eleições de 1994 encontra-se em Fernandes (1995) que também constatou o crescimento do centro.
}

Tabela 35

Evolução dos blocos ideológicos (\%)

\begin{tabular}{l|c|c|c|c}
\multicolumn{1}{c|}{ Blocos } & 1990 & 1994 & 1998 & Diferença 1998/1990 \\
\hline Direita & 49,3 & 37,6 & 36,1 & $-13,2$ \\
\hline Centro & 30,6 & 40,0 & 42,1 & $+11,5$ \\
\hline Esquerda & 20,1 & 22,4 & 21,8 & $+1,7$ \\
\hline Total & 100,0 & 100,0 & 100,0 & -
\end{tabular}

No conjunto, ocorreram somente pequenas mudanças, ainda que não dramáticas, no perfil ideológico e partidário dos Estados e, portanto, do País. $^{8}$

\section{Conclusão}

Apesar dos aspectos negativos que surgem do cotejo entre metas ideais e a realidade do funcionamento dos partidos, o sistema partidário, ao longo dos últimos anos, vem apresentando melhores resultados no que tange à sua representatividade, à disciplina interna, à organização e principalmente ao funcionamento parlamentar. A continuidade do sistema democrático e a repetição das competições eleitorais, com menos intervenções externas ao sistema, devem conduzir à sedimentação do multipartidarismo brasileiro, levando a cerca de quatro a cinco partidos efetivos e, possivelmente, à pequena diminuição do número total de partidos parlamentares. Mas as dimensões das magnitudes dos colégios eleitorais e as diferenças sociais entre os Estados sugerem a persistência dos pequenos partidos, provavelmente girando em torno dos quatro ou cinco maiores partidos. ${ }^{9}$ Um indicador nessa direção foi o aumento da proporção de cadeiras do conjunto das seis principais legendas em comparação com as outras. (Como já vimos, na CD que resultou das eleições de 1990, as

\footnotetext{
${ }^{8}$ Uma apreciação mais aprofundada implicaria considerar o voto para as assembleias legislativas, para o Senado e para os cargos executivos. Essa tarefa nos levaria para longe do nosso objetivo. O leitor interessado encontra análises mais amplas sobre as eleições de 1990 e 1994 em Fernandes (1995), Rodrigues (1995) e Lima Jr. (1997), e dados eleitorais para todas as eleições e para todo o País (1982-1996) em Nicolau (1998).

É claro, nesse ponto, que a legislação eleitoral 6 um dos fatores importantes na determinação do número de partidos. Mas não estamos considerando, aqui, a hipótese, sempre possível, de mudanças nas regras do jogo.
} 
bancadas dos seis partidos cuja composição social analisamos totalizavam $75 \%$ da legislatura; em 1994, 77\% e, em 1998, 84\%.)

Projetando os resultados das três últimas eleições para a Câmara dos Deputados, parece possível o seguinte prognóstico:

Consolidação do PMDB como partido de tamanho médio.

Continuação do declínio do PDT.

Consolidação da supremacia do PFL no campo da direita.

Ligeiro declínio do PPB.

Crescimento do PSDB.

Avanço do PT no campo da esquerda em detrimento do PDT.

Redução do número de partidos efetivos na $\mathrm{CD}$, apesar da persistência dos pequenos partidos.

São prognósticos derivados de tendências a partir de variações percentuais que decorrem de resultados anteriores para a CD. Seria ocioso dizer que a disputa por cadeiras nas eleições proporcionais sofre os efeitos da competição pelo controle dos Executivos federal e estaduais. Nesse nível da luta política, das competições majoritárias, as consequências da volatilidade do eleitorado, da personalidade dos candidatos e das mágicas do marketing político têm forte autonomia ante as estruturas partidárias. Como consequência, as disputas por postos nos Executivos tenderiam a influenciar os resultados das eleições proporcionais. Essa é uma crença fortemente consolidada no senso comum.

Mas, quando se observa mais de perto os resultados das disputas para a Presidência da República, ou para os governos dos Estados, vê-se que a vinculação entre eleições majoritárias e proporcionais é mais complicada e passa por vários filtros. O ranking das principais legendas no Parlamento federal não foi radicalmente alterado pelos resultados dos candidatos que apresentaram, ou apoiaram, para funções executivas. $\mathrm{O}$ fato de o candidato do PT para a Presidência da República ter estado sempre, nas últimas eleições, entre os primeiros nas pesquisas de intenção de voto, não fez com que o PT ultrapassasse o PFL ou o PMDB na CD. Tampouco, os péssimos resultados colhidos pelo $\mathrm{PMDB}$ nas eleições presidenciais expulsaram essa legenda do clube dos grandes partidos. Do mesmo modo, os êxitos e malogros do principal líder do PDT não afetaram significativamente a dimensão da bancada pedetista na Câmara dos Deputados.

O exame das últimas disputas comprova que as eleições proporcionais, embora possam ser influenciadas positiva ou negativamente pela presença, ou ausência, de candidatos de peso em postos majoritários, têm uma dinâmica própria. Os resultados das eleições proporcionais, de um lado, e os das majoritárias, de outro, têm coeficientes de autonomia elevados que variam em contextos políticos específicos.

Um fator que parece influenciar fortemente os resultados para a CD (e para as Assembleias Legislativas) são os arranjos partidários estaduais, nos quais o governador do Estado é figura de primeiro plano, como já salientado por vários autores. Assim, como não convém minimizar a influência dos Executivos estaduais na dimensão das bancadas eleitas para a $\mathrm{CD}$, convém também não exagerá-la, porque muitas variáveis locais necessitam ser levadas em conta. A dinâmica das eleições proporcionais tem sua lógica própria que, numa escala difícil de mensurar, vem das vinculações dos parlamentares com grupos de interesses específicos. É por aí que as singularidades dos meios sociais locais influenciam as composições das representações nos Legislativos e impedem que o poder Executivo dos Estados determine, a seu bel-prazer, quem vai para a CD.

Assim, para concluir, entendemos que os dados aqui apresentados, bem como as pesquisas de outros cientistas políticos que trabalham na área de partidos e eleições, sugerem um mapa partidário relativamente estável, de pequenas mudanças, em processo de estruturação e não de desagregação. Esse desenvolvimento, desde 1990, tem vindo do próprio jogo do mercado político e eleitoral, com a sedimentação de tendências anteriormente existentes. Tudo indica que esse formato deve consolidar-se progressivamente, caso não haja intervenções impositivas externas que, para o bem ou para o mal, alterem as regras atuais. Mas, mesmo que elas ocorram, parece difícil que a composição do clube dos cinco maiores partidos sofra alguma alteração radical nas próximas eleições, entendendo por "alteração radical" a substituição de um (ou mais) dos seus atuais membros por outros. 


\section{PROCEDIMENTO METODOLÓGICO}

A leitura desta parte não é necessária para a compreensão das análises. Os não especialistas, os que estão dando de barato a correção da metodologia utilizada (o termo me parece um pouco forte, mas fica) e os que estão mais interessados no conteúdo das interpretações podem dispensar a leitura desta parte. As explicações oferecidas no inicio são suficientes, mas o detalhamento da metodologia adotada é necessário para os nossos colegas cientistas sociais, para os leitores mais exigentes e para todos os que queiram saber mais sobre os critérios que utilizamos, os problemas encontrados e o modo como procuramos superá-los.

\section{As profissões/ocupações}

A construção das profissões/ocupações foi relativamente arbitrária. Dois critérios foram utilizados. O primeiro, obviamente, foi a importância numérica de cada uma das profissões/ocupações encontrada na listagem preliminar de todas as atividades exercidas pelos parlamentares. Esse critério pode ser denominado quantitativo porque serviu para indicar os segmentos socio-ocupacionais de maior peso na $\mathrm{CD}$. A escolha do segundo critério foi mais de natureza qualitativa porque foi guiada pela intenção de detectar a presença de grupos numericamente pouco expressivos no interior da $\mathrm{CD}$, mas importantes na sociedade inclusiva.

O objetivo era ter elementos para a apreensão mais detalhada da composição social de cada legenda individual a fim de medir suas possíveis relações com a ideologia partidária. Se esses segmentos profissionais, muito minoritários, fossem, por exemplo, desviados para "outras categorias" (como algumas vezes se procede nas tabelas com os fenômenos de frequência muito baixa), as informações sobre esses grupos ocupacionais minoritários estariam perdidas. Por sua vez, também a percepção da composição de cada partido ficaria prejudicada. Por exemplo: do prisma de seu espaço no interior da $\mathrm{CD}$, os trabalhadores manuais, lavradores e assalariados do setor de serviço poderiam ser incluídos em "outras categorias". Mas, caso assim procedêssemos, perderíamos uma informação importante relativa à distribuição dos setores populares nos seis partidos.
Portanto, houve uma dose inevitável de arbítrio na construção das categorias profissionais e ocupacionais com as quais trabalhamos na medida em que serviram a determinados objetivos do pesquisador. Nesse ponto, indiscutivelmente, hipóteses e teorias - que foram apriorísticas com relação ao material empírico coletado e elaborado de modo a ser operacionalizado na pesquisa - influenciaram a criação das categorias em que, necessariamente, teriam de ser alocadas as profissões dos parlamentares. Mas não seria necessário ressaltar que a autonomia do pesquisador na manipulação do material empírico é limitada por uma lógica que advém do próprio material e que veta construções incongruentes e absurdas em face de todo um conjunto existente de conhecimentos sociológicos e do senso comum. Assim, não faria sentido elaborar uma categoria "empresários e operários". Faria sentido, no entanto, segundo as intenções do pesquisador, incluir juízes e delegados de polícia, não na categoria de "advogados", mas na de membros da administração pública.

Desse ângulo, a existência, nesse estudo, de uma categoria para incluir o pessoal político que veio do setor público está ligada ao nosso interesse de obter dados mais exatos sobre os vínculos da classe política com o setor estatal. A mesma observação vale para os professores, cuja atuação e importância política, como grupo distinto, procuramos captar. ${ }^{1}$

Apesar da fixação dos critérios acima, apareceram muitos casos de dúvida, em que a opção para a classificação socioprofissional não era clara e indiscutível. Uma solução para reduzir a interferência subjetiva do pesquisador seria optar simplesmente por registrar a profissão ou as profissões que os próprios parlamentares apontaram no Repertório Biográfico da $\mathrm{CD}$ e efetuar uma tabulação separando a primeira, a segunda ou a terceira profissão/ocupação. E, desse modo, se eliminaria a dose de subjetividade do pesquisador e a sua responsabilidade de opção. A distribuição final das profissões e ocupações seria a indicada pelos deputados e os leitores saberiam da utilização desse critério. $\mathrm{O}$ risco, com esse procedimento, seria o de aceitar, sem um exame crítico, as autodefinições ocupacionais e profissionais registradas pelos parlamentares

${ }^{1}$ Esses segmentos profissionais não aparecem em alguns bancos de dados e em algumas pesquisas. É o caso de um levantamento do DIAP (Departamento Intersindical de Assessoria Parlamentar ) de 1998, sobre as profissões nesta 51 Legislatura que distingue apenas o "servidor público" (onze casos) entre os parlamentares eleitos. 
e que são definidas, muitas vezes, pelo diploma universitário. Mas não foi esse o caminho que resolvemos seguir, o que levou ao reexame das profissões apontadas no Repertório.

Uma razão que nos pareceu aconselhar a adoção desse procedimento foi o fato de que a aceitação, sem glosa, da transcrição das profissões indicadas no Repertório levava a subestimar o número de parlamentares com emprego público e o de empresários, justamente um aspecto que queríamos captar. O possuidor de diploma em Direito, que é juiz ou que ocupa uma posição importante no Estado, ou outros que exercem funções que não têm a ver com as atividades advocatícias, poderia ser classificado entre os advogados, se a atenção fosse para o diploma universitário. Poderia, de outro ângulo, ser incluído no funcionalismo público. A mesma observação é válida para outras situações em que as pessoas têm uma função no Estado sem relação com o diploma obtido ou com sua formação profissional. Esses casos, como indicamos antes, foram incluídos no grupo dos funcionários públicos e ocupações governamentais.

Talvez por isso, no tocante às porcentagens das categorias profissionais presentes na $\mathrm{CD}$, na comparação de nossos resultados com os de outros pesquisadores, há algumas discrepâncias. Parte delas pode ser resultado de nossos erros ou dos de meus colegas. Na maioria das vezes, as diferenças não parecem afetar as tendências principais das distribuições ocupacionais. Entretanto, acredito (mas é difícil apresentar evidências) que as diferenças significativas (que existem) entre os dados desta pesquisa e os dos estudos de outros pesquisadores vêm do uso de critérios diferentes no que diz respeito à construção das categorias de atividades ocupacionais e econômicas em que cada parlamentar foi incluído. Como salientamos inicialmente, os grupos e subgrupos de profissões não surgem automaticamente da realidade, mas tendem a ser construções dos pesquisadores de acordo com certas teorias e em função do que se pretende explicar ou compreender. Por exemplo; Eli Diniz e Renato Boschi, num estudo sobre a adaptação do empresariado às mudanças em andamento na sociedade brasileira, distinguiram quatro subgrupos, mas agregados em categorias diferente das que utilizamos: 1) empresários de indústria e finanças; 2) empresários de serviços diversos e de setores não especificados; 3) produtores rurais sem atividade empresarial e 4) "outras atividades" (Diniz \& Boschi, 2000, pp. 49-60). No caso, os autores pretendiam estudar os grupos de interesses em suas relações com o Estado. As categorias acima foram as que lhes pareceram mais adequadas a esse objetivo.

No cotejo das nossas tabelas com as de outros pesquisadores, houve diferenças também quanto ao número absoluto de deputados dentro de uma mesma categoria profissional. No caso dos empresários, o DIAP encontrou na atual legislatura 143 deputados dessa atividade profissional. Excluindose da base de cálculo percentual os casos em que informações não foram obtidas (onze casos), 28,5\% do total de deputados foram incluídos na categoria de empresários, porcentagem bem inferior à nossa, de 43,5\%. Ocorre que o DIAP separou os proprietários dos não proprietários e não incluiu no grupo empresarial os administradores e os corretores. Mesmo acrescentando onze ex-administradores e um ex-corretor no bloco dos empresários urbanos e rurais, essa categoria chegaria, pelos critérios do DIAP, a 30,8\%, diferença ainda grande com relação aos nossos dados. Não sabemos explicar a razão da diferença. É possível que ela se deva, por um lado, ao fato de termos estabelecido a classificação profissional utilizando várias fontes de dados além as informações contidas na publicação Deputados Brasileiros - Repertório Biográfico - 51 ${ }^{a}$ Legislatura.

Por outro, poderia acontecer que, em nossa pesquisa, em comparação com os dados do Repertório, a proporção de empresários tenha se elevado devido às alterações que procedemos após o exame das declarações de bens dos parlamentares (ver mais adiante). Se tivéssemos acompanhado as declarações de profissão/ocupação dos próprios deputados os nossos resultados estariam um pouco mais próximos dos do DIAP: teríamos 181 parlamentares $(35,3 \%)$ que declararam possuir pelo menos uma profissão/ ocupação do tipo empresarial. ${ }^{2}$

Outro elemento de comparação, pudemos encontrar em André Marenco dos Santos em sua pesquisa sobre as formas de recrutamento parlamentar, carreira parlamentar e experiência legislativa entre 1946 e 1998 (Santos, 2000). A composição social do Parlamento não era o

${ }^{2}$ Por exemplo: um deputado do PFL, do Acre, posteriormente cassado pela Câmara Federal, foi classificado pelo DIAP como "militar", profissão indicada no Repertório da $51^{\mathrm{a}}$ Legislatura. Contudo, para nós, após o exame da sua declaração de bens, e obedecendo aos critérios formais que estabelecemos, foi também tabulado como "empresário rural". 
principal objetivo da pesquisa, mas Santos oferece alguns dados sobre a composição de várias legislaturas passadas até a atual. Foi possível, assim, o cotejo de seus dados com os nossos. De modo geral, as mesmas categorias profissionais das quais habitualmente saem os membros da classe política estão presentes em ambos os estudos.

Mas há diferenças, algumas delas decorrentes da construção de categorias profissionais diferentes, o que dificulta comparações. Por exemplo: Santos encontrou 2,8\% de trabalhadores manuais. No nosso caso, se somarmos os trabalhadores industriais qualificados com os lavradores chegamos a 2,0\%, diferença muito pequena dos números de Santos. Mas, para outras profissões, as discrepâncias foram mais acentuadas. Os advogados, pelos cálculos de Santos, seriam $17,7 \%$ e pelos do DIAP, 18,3\%. Pelos critérios que estabelecemos - deputados formados em Direito que estavam efetivamente exercendo a profissão antes da primeira eleição —, os advogados seriam apenas 9,7\%. (Seguindo as profissões declaradas no Repertório pelos deputados, que podem indicar mais de uma, encontramos 26,9\% de advogados.).

Quanto aos proprietários, Santos registrou $8,8 \%$ de proprietários agrícolas e $18,9 \%$ de empresários urbanos, enquanto pelos nossos critérios os empresários rurais seriam 10,1\%, os empresários urbanos, $28,5 \%$ e os empresários com atividades mistas, 4,9\%. (Essa última subcategoria não aparece em Santos e na relação do DIAP.) No caso dos funcionários públicos, os nossos números e os de Santos são praticamente iguais: 17,5\% e $17,9 \%$, respectivamente (não incluindo, no nosso caso, os diretores de bancos estatais: $2,5 \%$ ).

Outros exemplos da variedade de critérios, com resultados diferentes, aparecem também em outros trabalhos. David Fleischer (1981), num dos primeiros estudos sobre a composição da classe política brasileira, baseando-se em múltiplas fontes, tomou como ponto de referência a ocupação principal combinando ramo de atividade (por exemplo, comércio, banco, finanças) e profissão (professores, juízes, advogados) (Fleischer, 1981).

Sérgio Soares Braga, por sua vez, num estudo sobre a Constituinte de 1946, definiu apenas três grandes grupos: proprietários, profissões intelectuais e profissões manuais, com suas divisões internas (Braga, 1998).
Assim, é óbvio que as regras de classificação fixadas pelos pesquisadores acabam por aumentar (ou reduzir) o peso que assume cada segmento socioprofissional nos órgãos legislativos estudados e, desse modo, afetam o perfil social dos partidos. No caso do DIAP, com exceção do grupo dos empresários (em que empresários urbanos e rurais foram agregados), as demais profissões/ocupações estão bastante desagregadas. Para se tornarem operacionais para cálculos de correlação, necessitariam ser reduzidas a um número menor de categorias mais abrangentes e, aí, surge certa liberdade na criação das categorias socio-ocupacionais para cada pesquisador. $^{3}$

No final dessa sumária avaliação de alguns dos mais recentes trabalhos na área, vê-se que uma dose de arbítrio inevitável se introduz na construção das categorias ocupacionais e profissionais, fato que tem resultados diferentes quanto à avaliação do peso e à influência dos segmentos sociais nos órgãos de decisão política. Não pretendemos estar isentos desse tipo de viés. Por isso mesmo, gostaríamos de insistir sobre as razões que levaram aos critérios que adotamos.

No nosso caso, o objetivo era captar possíveis correlações entre profissões/ocupações (indicativas de status, num sentido amplo) e atitudes e valores políticos. Por isso, procuramos agregar numa categoria mais ampla - a dos empresários, proprietários e executivos - todas as profissões, ocupações e atividades ligadas ao capital, ao mercado, à situação de empregador que, tradicionalmente, são consideradas mais propensas a posições de direita ou conservadoras, o que, seguramente, pode ser objeto de discussão. ${ }^{4}$ Em contrapartida, tentamos detectar as possíveis, prováveis e variadas conexões com o Estado que servem como fonte de rendimento e poder e que, por isso mesmo, afetam as orientações políticas, programáticas e ideológicas das pessoas. Foi basicamente por esse motivo que o diploma

${ }^{3}$ Entendo que a listagem do DIA P leva à subestimação dos funcionários públicos e das ocupações governamentais. No caso da classificação de Santos (2000), um problema que vejo é o desaparecimento dos professores no quadro ocupacional das várias legislaturas, categoria que, no Brasil e em outros países, tende a ter, como vimos, uma presença forte na política.

${ }^{4}$ Entendo que muito conservadorismo pode ser encontrado no campo da chamada esquerda. Creio mesmo que os partidos de esquerda, em muitos aspectos, são mais conservadores do que os de direita e de centro, mas trata-se de uma opinião pessoal, que não vem ao caso nesta pesquisa. 
de nível superior, muitas vezes usado para indicar a ocupação ou a atividade econômica, não foi um critério para a inserção no grupo profissional, a não ser quando a profissão definida pelo diploma estava sendo de fato exercida.

Outro aspecto importante deve ser assinalado. Fazer parte de um grupo profissional num dado momento nada diz das trajetórias individuais, isto $e$, de onde vieram as pessoas para compartilhar de um mesmo patamar no sistema de estratificação social. Os que estão subindo e os que estão descendo social e economicamente podem, num dado momento, cruzaremse num mesmo ponto, mas vindos de experiências diversas, carregando bagagens culturais de universos sociais opostos, que podem ser o do aristocrata decadente ou o do plebeu em ascensão, trajetórias inversas que podem afetar suas visões do mundo e suas atitudes políticas. Eventualmente, essas trajetórias poderiam ser captadas pelo exame das profissões/ocupações dos parlamentares. Uma dificuldade, aqui, além do tempo requerido, está na correta obtenção de dados.

Entretanto, nesta pesquisa, esses movimentos de mobilidade vertical não foram investigados. Diante disso, uma vez que durante suas vidas as pessoas frequentemente passam por várias experiências profissionais além de terem, num mesmo momento, mais de uma atividade ocupacional - para a homogeneização dos procedimentos de escolha da profissão/ocupação, tomamos como critério de classificação a(s) última(s) ocupação(ôes)/ profissão(ôes) que os parlamentares tinham ou exerciam antes da primeira eleição para algum cargo ou função pública. ${ }^{5}$

Acreditamos que esse critério dê uma percepção relativamente adequada do status social imediatamente anterior à entrada na classe política. ${ }^{6}$ Quando mais de uma última ocupação/profissão foram exercidas ao mesmo tempo, todas foram assinaladas, o que faz com que, nas tabelas e quadros, a soma das porcentagens ultrapasse $100 \%$. Uma exceção à regra da "última ocupação" foi aberta para o caso dos empresários. Uma vez que essa atividade é bem mais compatível com a atividade parlamentar do que

\footnotetext{
${ }^{5}$ Foram considerados como primeiro cargo público eletivo: prefeito e governador, para funções executivas (como titular ou vice); e vereador, deputado estadual, deputado federal e senador, para funções legislativas.

${ }^{6}$ Dogan observa, para o caso francês, que mais de $90 \%$ dos representantes políticos, em sua primeira eleição parlamentar, já tinham "uma profissão bem definida que exigira uma certa formação e que lhes garantia os meios de subsistência" (Dogan, 1999, p. 174).
}

no caso de outras ocupações, os deputados que, depois de eleitos pela primeira vez se tornaram empresários, tiveram essa atividade classificada juntamente com a última profissão/ocupação. Achamos, pelo exame das declarações de bens, dezessete casos (4\% de 401) nessa condição.

\section{A composição das categorias}

No final, com a metodologia e os critérios utilizados, chegamos aos seguintes grupos ou categorias profissionais e ocupacionais cuja composição interna convém indicar.

Empresários - Esta categoria compreende três subgrupos: 1) os empresários urbanos; 2) os empresários rurais e 3) os empresários com atividades mistas, quero dizer, urbanas e rurais. Foram incluídos entre os empresários urbanos todos os deputados que eram (ou são ainda) proprietários, executivos, administradores, diretores e gerentes de empresas, de firmas e de companhias privadas industriais, comerciais e de serviços do meio urbano, inclusive proprietários de hospitais e de estabelecimentos de ensino, diretores de clubes esportivos e corretores de imóvel. Foram incluídos entre os empresários rurais todos os proprietários de terra, fazendeiros, produtores rurais, administradores de fazenda e pecuaristas ${ }^{7}$. Os parlamentares que tinham empreendimentos urbanos junto com outros rurais, ou com empreendimentos que envolviam a combinação dos dois setores, como o agro-business, aparecem nas tabelas sob a rubrica de empresários mistos. Tal como mostrou o exame das declarações de bens, um grupo minoritário dos empresários — urbanos, na sua maioria — são pequenos proprietários. Os executivos assalariados foram incluídos entre os empresários porque se trata de pessoal de comando identificado com os proprietários familiares ou acionistas, responsáveis (total ou parcialmente) pelo êxito da empresa.

Em contrapartida, não foi considerada a dimensão/valor da empresa ou da atividade econômica. Desse modo, foram classificados entre os empresários urbanos os parlamentares dos seguintes ramos de atividade:

\footnotetext{
${ }^{7}$ Geralmente, no Repertório, está indicado "empresário rural” ou, na maior parte das vezes, apenas "empresário". A complementação do setor de atividade foi efetuada por nós após o exame da carreira profissional descrita no próprio Repertório (quando esse dado existia), da declaração de bens ou do Dicionário Histórico-Biográfico Brasileiro, da FGV.
} 
empresários sem especificação; proprietários, sócios/diretores de televisão/ rádio; comerciantes; industriais; proprietários/diretores de hospitais ou estabelecimentos de ensino privados; administradores, gerentes, diretores de empresas; corretores de todos os tipos de atividade; diretores de sociedades recreativas/esportivas. Foram definidos como empresários rurais os agropecuaristas, os avicultores e todos os empresários cujo ramo específico de atividade rural não pudemos localizar.

Profissionais liberais - As profissões liberais tradicionais são compostas principalmente por médicos (12\%), advogados (10\%) e engenheiros $(6 \%)$. Os dentistas, farmacêuticos e veterinários, somente quatro casos no total, estão nesse grupo.

As profissões intelectuais - São aquelas cujo exercício requer também conhecimentos de nível superior, geralmente atestado por um diploma universitário. Aí estão principalmente os economistas (1\%) e mais os arquitetos, sociólogos, músicos, geólogos, assistentes sociais, todos em número muito pequeno. No conjunto, os parlamentares dessa categoria formam cerca de $5 \%$ da $\mathrm{CD}$.

$O$ magistério - A categoria dos professores abrange todo tipo de atividade docente, do setor público ou privado, de todos os níveis de magistério, incluindo professores de cursinhos e de escolas técnicas. Tratase de uma categoria numerosa na $\mathrm{CD}$. Os deputados que foram professores do magistério público superior constituem o maior segmento dessa categoria (6\%). Em 3\% dos casos, não foi possível identificar a vinculação empregatícia dos parlamentares que exerceram atividade docente antes de se elegerem pela primeira vez para algum cargo público. Foram para a categoria "outros professores" os docentes do ensino privado superior (5\%), os do ensino público (1\%), os do colegial público (1\%), os do colegial privado $(0,4 \%)$ e os de cursinhos $(0,4 \%)$. Os proprietários de estabelecimentos de ensino foram agregados ao grupo dos empresários urbanos.

Os funcionários públicos - O bloco dos deputados que foram funcionários públicos abrange os parlamentares que tiveram altos cargos do setor público federal, estadual e municipal. Foram colocados na subcategoria da alta burocracia federal, estadual ou municipal os que tiveram, como última ocupação, cargos ou funções de auditores, procuradores, promotores, diretores de institutos, de autarquias, de empresas estatais, delegados de polícia e outros cargos ou função de nível equivalente. Estão nesse grupo os funcionários das Câmaras de vereadores. Esse segmento do alto funcionalismo compreendeu $16 \%$ do total dos deputados. O item "baixo e médio funcionalismos públicos" incorporou cabos, oficiais das Forças Armadas, um fiscal de aduana e todos que declararam apenas "servidor público". Somados, representam $2 \%$ do total da CD. Os diretores de bancos estatais compreendem os que ocupavam cargos nas diretorias de bancos federais ou estaduais e representam $3 \%$ do total.

"Comunicadores" - Inclui todos os profissionais da área de comunicação de massa, que, por facilidade de expressão, estão sendo denominados aqui "comunicadores". Entraram nessa categoria: os radialistas, os locutores de rádio, os apresentadores de tevê e os jornalistas. Numericamente, diante do corpo eleitoral, representam uma parcela mínima, mas o tipo de atividade que perfazem facilita a ascensão a posições políticas eletivas. Constitui uma porta de entrada para a atividade política profissional sem necessidade de outros trunfos político-eleitorais, como o apoio de associações, sindicatos, máquina partidária, rede familiar e/ou grande recurso financeiro. Os "comunicadores" que eram proprietários ou sócios de estações de rádio ou televisão foram para a categoria dos empresários urbanos.

Os empregados não manuais em serviços - A categoria dos empregados não manuais de serviços contém cinco bancários, quatro técnicos em manutenção e de contabilidade, dois técnicos agrícolas, um escrevente, um programador de produção e um delineador naval.

Trabalhadores industriais qualificados - Nessa categoria encontramos apenas sete casos: seis metalúrgicos e um gráfico.

Lavradores - Houve somente três deputados que apontaram "lavrador" como profissão, sem mais especificações ( $0,6 \%$ do total). Juntamente com os trabalhadores industriais, esse grupo poderia ser entendido como a representação das classes baixas na CD.

Pastores e padres - Houve dezoito casos de deputados que tinham uma ocupação religiosa: dezesseis pastores (ou ministros) e dois padres (4\% do total da CD). 
"Políticos" - Sob essa designação, foram incluídos os parlamentares que entraram muito cedo para a política e tiveram, antes de obterem um diploma de nível superior, um cargo no governo ou em alguma entidade legislativa por indicação política e, a rigor, nunca chegaram a exercer outra profissão que não a de político. Há $0,8 \%$ da CD nessa categoria.

Sem informação - Em dois casos $(0,4 \%$ da $\mathrm{CD})$ não obtivemos informações seguras que permitissem classificar profissionalmente o parlamentar.

\section{As fontes de dados}

A principal fonte de dados utilizada foi o Repertório Biográfico da Câmara dos Deputados - da 51 ${ }^{a}$ Legislatura (1999-2003). Os repertórios biográficos que têm sido usados também por outros pesquisadores são publicados pela CD para cada legislatura. A publicação traz um perfil dos parlamentares eleitos e os dados são fornecidos pelos próprios deputados. Às vezes, as informações relativas a alguns itens são imprecisas; outras vezes, estão ausentes. É possível que, em alguns casos, a falta de informação seja intencional ${ }^{8}$; em outros casos, pode ser o resultado de descuido do próprio parlamentar ou, mesmo, de erros na organização e edição dos repertórios.

Deve-se ressaltar, no entanto, que a grande maioria dos parlamentares preencheu todos os itens com informações sobre sua pessoa (local e data de nascimento, Estado pelo qual foi eleito, profissão,

\footnotetext{
${ }^{8}$ Alguns exemplos: no item "filiações partidárias" do Repertório é mais frequente a ausência de dados sobre as legendas às quais o parlamentar pertenceu quando se trata de partidos que perderam prestígio, como a Arena ou o PRN. Além disso, no item "nascimento", em dois casos (de deputadas) faltaram as datas de nascimento, obtidas posteriormente por meio de contato com seus escritórios. Dificuldade maior, e mais frequente, ocorreu no tocante à atividade profissional e ocupacional indicada no item "profissão" que, pelos critérios de classificação que estabelecemos, deveria ser alterada. Em todos esses casos e em outros em que faltaram dados no Repertório (dez casos ao todo), recorrendo a telefonemas, e-mails dirigidos aos próprios parlamentares e ao auxílio de outras fontes, as lacunas foram preenchidas, em oito casos pelos escritórios dos parlamentares e, em dois casos, mediante conversa pessoal com o parlamentar. A todos eles, agradecemos a gentileza no atendimento de nossas solicitações.
}

escolaridade etc.), assim como sobre a carreira política (legendas a que pertenceram, cargos públicos ocupados, eleições anteriores, experiência profissional e outras informações). A cada legislatura, os repertórios vêm-se tomando mais informativos e organizados, sendo, assim, uma importante fonte para estudos sobre os parlamentares, em particular, e sobre a classe política brasileira, em geral. Contudo, não está excluída a possibilidade de que certas informações sobre a carreira do parlamentar tenham sido deixadas de lado no Repertório que usamos e escapado de nossa percepção. Mas não parece que algo realmente importante, para os fins desta parte do estudo, tenha faltado.

Além dos dados contidos no Repertório Biográfico, procuramos apoio em outras fontes. Uma das principais foi o Dicionário HistóricoBiográfico Brasileiro ( $1^{\mathrm{a}}$ e $2^{\mathrm{a}}$ edições), extraordinário trabalho realizado pelo Centro de Pesquisa e Documentação de História Contemporânea do Brasil (CPDOC) da Fundação Getúlio Vargas.

\section{As declarações de bens}

A tarefa de reclassificação das profissões/ocupações indicadas no Repertório foi facilitada e realizada com mais segurança pelo exame das declarações de bens que os parlamentares apresentam nos Tribunais Regionais Eleitorais dos seus Estados quando do registro de suas candidaturas. Do total das declarações solicitadas aos Tribunais Regionais, recebemos 412 (80,3\% do total da $\mathrm{CD})$, referentes a 21 Estados, dos quais foram aproveitadas $401(78,2 \%) .{ }^{9}$ Em $10,2 \%$ dos 401 casos foram feitas alterações no item "profissão" do Repertório, seja para completar

\footnotetext{
${ }^{9}$ Em onze casos, não foi possível realizar a análise profissional/ocupacional, visto que sete das declarações enviadas eram declarações de suplentes dos parlamentares eleitos em 1998 e em outros quatro casos os valores patrimoniais não foram expressos. Vinte e um Tribunais Regionais, aos quais agradecemos, enviaram as declarações de bens dos parlamentares eleitos pelos respectivos Estados: Sul: Rio Grande do Sul, Santa Catarina e Paraná; Sudeste: São Paulo, Rio de Janeiro, Espírito Santo e Minas Gerais; Centro-Oeste: Distrito Federal, Mato Grosso do Sul, Mato Grosso; Nordeste: Alagoas, Pernambuco, Rio Grande do Norte Ceará e Piauí; Norte: Pará, Rondônia, Roraima, Tocantins, Amapá e Acre. Não enviaram as declarações os TREs do Amazonas, de Goiás, do Sergipe, da Bahia, do Maranhão e da Paraíba.
} 
informações vagas (tal como "empresário", sem mais especificações) seja para mudar a profissão/ocupação registrada no Repertório (41 casos).

Cerca da metade das alterações que efetuamos foi no interior da categoria dos empresários, de modo a localizar o ramo e a atividade dos parlamentares que indicaram apenas "empresário" como profissão. A outra alteração importante foi a passagem de profissionais liberais e funcionários do Estado - profissões indicadas no Repertório - para a categoria de empresário, como se pode perceber abaixo. Ao todo, o número absoluto de empresários aumentou em dezessete casos.

Quadro 10

Alterações da classificação das ocupações a partir das declarações de bens

\begin{tabular}{|c|c|c|}
\hline Tipo de Alteração Total & $\mathrm{N}$ & $(\%)$ \\
\hline $\begin{array}{l}\text { Para redefinir a classificação } \\
\text { da profissão/ocupação empresarial (dentro do próprio } \\
\text { grupo de empresários) }\end{array}$ & 22 & 53,7 \\
\hline De funcionário do Estado para empresários & 8 & 19,6 \\
\hline De profissões liberais e intelectuais para empresários & 6 & 14,6 \\
\hline De políticos para empresários & 2 & 4,9 \\
\hline De comunicadores para empresários & 1 & 2,4 \\
\hline De empresários para profissões liberais & 1 & 2,4 \\
\hline De “sem informação" para Estado* & 1 & 2,4 \\
\hline Total & 41 & 100,0 \\
\hline \multicolumn{3}{|c|}{$\begin{array}{l}\text { * Representa um caso que o item profissão/ocupação do Repertório } \\
\text { Biográfico não permitia a classificação, devido à falta de informações. Por } \\
\text { meio da declaração de bens, apresentada juntamente com a declaração de } \\
\text { renda pelo parlamentar, observou-se que seus rendimentos advinham de um } \\
\text { órgão estatal. }\end{array}$} \\
\hline
\end{tabular}

Em 89\% dos 401 deputados cujas declarações de bens foram aproveitadas não houve alteração na profissão/ocupação analisada a partir do Repertório. Na hipótese de que a mesma proporção de alterações $(10,2 \%)$ que efetuamos se repetisse para os 112 deputados para os quais não obtivemos a declaração de bens, seriam de se esperar alterações em cerca de onze casos do total de parlamentares, o que significa a expectativa de que
2,1\% dos 513 deputados teriam sua profissão/ocupação alterada e, a julgar pelas reavaliações a que procedemos, aumentando muito ligeiramente a proporção total de empresários. ${ }^{10}$

No que toca à questão patrimonial, no total de 401 casos a partir dos quais construímos as faixas patrimoniais, em 22 casos $(5,5 \%)$ a localização na faixa patrimonial foi efetuada por estimativa porque o valor dos bens não constava das declarações. A estimativa, feita por nós, procurou levar em consideração o valor dos bens móveis e imóveis de acordo com a época de aquisição em cotejo com outras declarações do mesmo Estado. É evidente que não está excluída a possibilidade de erros, mas as estimativas destinavam-se apenas a possibilitar a inclusão dos bens do parlamentar em uma das faixas patrimoniais com intervalos de classes relativamente amplos. Não houve, pois, para esses casos, tentativa de se chegar a um valor exato do patrimônio.

As 401 declarações de bens que foram utilizadas compreendem a maioria dos deputados dos seis partidos, mas não na mesma proporção. Mais especificamente: as declarações de bens que obtivemos dos TREs de cada unidade da Federação abrangem o universo dos parlamentares de cada Estado. Mas a força dos partidos varia por unidade da Federação. Por isso, em termos das bancadas federais, algumas legendas estão mais bem representadas do que outras. Nesse sentido, a ausência de declarações dos parlamentares baianos, como indica o quadro seguinte, introduziu um viés maior nos dados da bancada do PFL. Por isso, provavelmente, as distribuições dos parlamentares do PFL e da Bahia estão subestimadas porque, como já fizemos notar, $44 \%$ dos deputados baianos eram empresários; dos vinte que eram do PFL, dez eram empresários.

O exame das 401 declarações, além de permitir corrigir algumas das profissões/ocupações assinaladas no Repertório, possibilitou o cruzamento dos níveis patrimoniais com as legendas dos seis partidos. É possível que existam falhas nas declarações de bens e que parte do patrimônio dos deputados não tenha sido declarada. Mas nem sempre ocultar

\footnotetext{
${ }^{10}$ A declaração de bens, queremos repetir, refere-se ao patrimônio e não deve ser confundida com a declaração de renda que não é pública e que é entregue à Receita Federal. No entanto, a maioria dos parlamentares entregou no TRE de seu Estado cópia da própria declaração de renda, o que, em alguns casos, facilitou a tarefa de classificação ocupacional do deputado.
} 
intencionalmente parte dos bens pode ser um ato racional da parte de um candidato, porque se arrisca, algum dia, a ter que explicar o acréscimo dos seus bens "antes" e "depois".

Assim, talvez não tenha havido muita ingenuidade de nossa parte na utilização das declarações. De todo modo, elas se mostraram muito consistentes com as profissões/ocupações e com as orientações políticas e ideológicas dos partidos e dos políticos. Cotejando as declarações de bens com outras informações dos próprios deputados, não encontramos discrepâncias entre patrimônio, carreira profissional, escolaridade e ocupação. $\mathrm{O}$ fato não prova a exatidão das declarações apresentadas, mas sugere que as distorções que nelas possam existir não as tornam inúteis para os nossos fins. Além disso, para a presente pesquisa não interessou o valor patrimonial exato, mesmo porque os valores individuais estão inseridos em classes com limites relativamente amplos e tratados quantitativamente. Pequenos erros que mantenham o patrimônio do parlamentar na mesma faixa não alteram os cálculos. Todavia, erros de maior magnitude, que levassem à mudança de faixa patrimonial, já teriam consequências mais relevantes nas interpretações, mas não tivemos meios de controlar essa possibilidade.

\section{ANEXOS}

1. Profissões/ocupações desagregadas por bloco ideológico (\%)

\begin{tabular}{l|c|c|c|c}
\multicolumn{1}{c|}{ Profissões/Ocupações } & $\begin{array}{c}\text { Direita } \\
\text { PPB/PFL }\end{array}$ & $\begin{array}{c}\text { Centro } \\
\text { PMDB/PSDB }\end{array}$ & $\begin{array}{c}\text { Esquerda } \\
\text { PDT/PT }\end{array}$ & CD \\
\hline Empresários urbanos & 40,0 & 28,6 & 6,0 & 28,5 \\
\hline Empresários rurais & 15,7 & 9,9 & 2,4 & 10,1 \\
\hline Empresários mistos & 7,9 & 3,8 & 0,0 & 4,9 \\
\hline Profissões liberais tradicionais & 21,2 & 30,2 & 33,3 & 27,1 \\
\hline Profissões intelectuais & 1,8 & 6,0 & 6,0 & 4,5 \\
\hline Altos cargos do gov. federal & 7,9 & 5,5 & 0,0 & 4,9 \\
\hline Altos cargos de gov. estaduais & 10,3 & 10,4 & 3,6 & 9,0 \\
\hline $\begin{array}{l}\text { Altos cargos de gov. } \\
\text { municipais }\end{array}$ & 0,6 & 3,3 & 1,2 & 1,8 \\
\hline $\begin{array}{l}\text { Baixo e médio funcionalismos } \\
\text { públicos }\end{array}$ & 1,8 & 1,6 & 1,2 & 1,8 \\
\hline Diretores de banco & 0 & 6,0 & 1,2 & 2,5 \\
\hline Magistério público superior & 4,8 & 7,1 & 9,5 & 6,4 \\
\hline Outros professores & 3,6 & 8,8 & 20,2 & 9,4 \\
\hline Comunicadores & 6,1 & 3,3 & 7,1 & 6,4 \\
\hline Padres & 0,6 & 0 & 1,2 & 0,4 \\
\hline Pastores & 4,2 & 0,5 & 1,2 & 3,1 \\
\hline $\begin{array}{l}\text { Empregados não manuais em } \\
\text { serviços }\end{array}$ & 1,2 & 0 & 11,9 & 2,7 \\
\hline $\begin{array}{l}\text { Trabalhadores industriais } \\
\text { qualificados }\end{array}$ & 0,6 & 0 & 6,0 & 1,4 \\
\hline Lavradores & 0 & 0 & 3,6 & 0,6 \\
\hline "Políticos"* & 165 & 182 & 84 & 513 \\
\hline Sem informação & 0 & 1,6 & 1,2 & 0,8 \\
\hline N Refere-se a deputados que nunca exerceram uma atividade profissional.
\end{tabular}


2. Profissões/ocupações desagregadas por partido

Ocupações

Empresários urbanos

Empresários rurais

Empresários mistos

Profissões liberais tradicionais

Profissões intelectuais

Altos cargos do gov. federal

Altos cargos de gov. estaduais

Altos cargos de gov. municipais

Baixo e médio funcionalismos

Diretores de bancos estatais

Magistério público superior

Outros professores

Comunicadores

Pastores e padres

Empregados não manuais em

serviços

Trabalhos industriais qualificados

Lavradores

"Políticos"

Sem informação

$\mathrm{N}$

\begin{tabular}{|c|c|c|c|c|c|c|}
\hline PPB & PFL & PMDB & PSDB & PDT & PT & $\mathrm{CD}$ \\
\hline 40,0 & 40,0 & 30,1 & 27,3 & 12,0 & 3,4 & 28,5 \\
\hline 16,7 & 15,2 & 12,0 & 8,1 & 8,0 & 0 & 10,1 \\
\hline 11,7 & 5,7 & 4,8 & 3,0 & 0 & 0 & 4,9 \\
\hline 18,3 & 22,9 & 28,9 & 31,3 & 52,0 & 25,4 & 27,1 \\
\hline 1,7 & 1,9 & 2,4 & 9,1 & 8,0 & 5,1 & 4,5 \\
\hline 3,3 & 10,5 & 4,8 & 6,1 & 0 & 0 & 4,9 \\
\hline 8,3 & 11,4 & 15,7 & 6,1 & 8,0 & 1,7 & 9,0 \\
\hline 1,7 & 0 & 1,2 & 5,1 & 4,0 & 0 & 1,8 \\
\hline 1,7 & 1,9 & 1,2 & 2,0 & 0 & 1,7 & 1,8 \\
\hline 0 & 0 & 6,0 & 6,1 & 4,0 & 0 & 2,5 \\
\hline 5,0 & 4,8 & 8,4 & 6,1 & 8,0 & 10,2 & 6,4 \\
\hline 1,7 & 4,8 & 7,2 & 10,1 & 12,0 & 23,7 & 9,4 \\
\hline 8,3 & 4,8 & 0 & 6,1 & 4,0 & 8,5 & 6,4 \\
\hline 10,0 & 1,9 & 0 & 1,0 & 4,0 & 1,7 & 3,5 \\
\hline 1,7 & 1,0 & 0 & 0 & 0 & 16,9 & 2,7 \\
\hline 0 & 1,0 & 0 & 0 & 0 & 8,5 & 1,4 \\
\hline 0 & 0 & 0 & 0 & 0 & 5,1 & 0,6 \\
\hline 0 & 0 & 1,2 & 2,0 & 4,0 & 0 & 0,8 \\
\hline 0 & 0 & 1,2 & 1,0 & 0 & 0 & 0,4 \\
\hline 60 & 105 & 83 & 99 & 25 & 59 & 126,7 \\
\hline
\end{tabular}

3. Profissões/ocupações desagregadas por patrimônio

(análise vertical)

\begin{tabular}{l|c|c|c|c|c|c|c|c}
\multirow{2}{*}{ Última ocupação } & \multicolumn{2}{|c}{ Baixo } & \multicolumn{2}{c}{ Médio-baixo } & \multicolumn{2}{c}{ Médio-alto } & \multicolumn{2}{c}{ Alto } \\
\cline { 2 - 10 } & $\%$ & $\mathrm{~N}$ & $\%$ & $\mathrm{~N}$ & $\%$ & $\mathrm{~N}$ & $\%$ & $\mathrm{~N}$ \\
\hline Empresários urbanos & 9 & 8,0 & 16 & 15,1 & 46 & 38,3 & 40 & 63,5 \\
\hline Empresários rurais & 3 & 2,7 & 6 & 5,7 & 17 & 14,2 & 13 & 20,6 \\
\hline Empresários mistos & 0 & 0 & 4 & 3,8 & 4 & 3,3 & 10 & 15,9 \\
\hline Prof. liberais tradic. & 29 & 25,9 & 34 & 32,1 & 36 & 30,0 & 6 & 9,5 \\
\hline Profissões intelectuais & 7 & 6,3 & 4 & 3,8 & 6 & 5,0 & 1 & 1,6 \\
\hline Magistério público superior & 10 & 8,9 & 8 & 7,5 & 7 & 5,8 & 1 & 1,6 \\
\hline Outros professores & 21 & 18,8 & 9 & 8,5 & 12 & 10,0 & 2 & 3,2 \\
\hline Altos cargos do gov. federal & 2 & 1,8 & 5 & 4,7 & 8 & 6,7 & 1 & 1,6 \\
\hline Altos cargos de gov. estaduais & 5 & 4,5 & 14 & 13,2 & 9 & 7,5 & 3 & 4,8 \\
\hline Altos cargos de gov. municipais & 2 & 1,8 & 5 & 4,7 & 1 & 0,8 & 0 & 0 \\
\hline Baixo e médio funcionalismos & 6 & 5,4 & 3 & 2,8 & 0 & 0 & 0 & 0 \\
\hline Diret. bancos estatais & 1 & 0,9 & 1 & 0,9 & 6 & 5,0 & 2 & 3,2 \\
\hline "Comunicadores" & 17 & 15,2 & 6 & 5,7 & 4 & 3,3 & 2 & 3,2 \\
\hline Pastores e padres & 7 & 6,3 & 4 & 3,8 & 3 & 2,5 & 2 & 3,2 \\
\hline Não manuais em serviços & 7 & 6,3 & 3 & 2,8 & 1 & 0,8 & 0 & 0 \\
\hline Trab. ind. qualificados & 5 & 4,5 & 2 & 1,9 & 0 & 0 & 0 & 0 \\
\hline Lavradores & 3 & 2,7 & 0 & 0 & 0 & 0 & 0 & 0 \\
\hline "Políticos" & 1 & 0,9 & 0 & 0 & 1 & 0,8 & 1 & 1,6 \\
\hline Sem informação & 0 & 0 & 1 & 0,9 & 0 & 0 & 0 & 0 \\
\hline Total de profissões & 135 & 120,5 & 125 & 117,9 & 161 & 134,2 & 84 & 133,3 \\
\hline Total de deputados & 112 & 100,0 & 106 & 100,0 & 120 & 100,0 & 63 & 100,0
\end{tabular}


4 - Profissões/ocupações desagregadas por patrimônio análise horizontal)

\begin{tabular}{l|c|c|c|c|c|c}
\multicolumn{1}{c|}{ Última ocupação } & Baixo & $\begin{array}{c}\text { Médio- } \\
\text { baixo }\end{array}$ & $\begin{array}{c}\text { Médio- } \\
\text { alto }\end{array}$ & Alto & $\mathrm{N}$ & Total \\
\hline Empresários urbanos & 8,0 & 15,2 & 41,1 & 35,7 & 112 & 100,0 \\
\hline Empresários rurais & 7,9 & 15,8 & 44,7 & 31,6 & 38 & 100,0 \\
\hline Empresários mistos & 0 & 21,0 & 21,1 & 57,9 & 19 & 100,0 \\
\hline Profissões liberais tradicionais & 27,6 & 32,4 & 34,3 & 5,7 & 105 & 100,0 \\
\hline Profissões intelectuais & 38,9 & 22,2 & 33,3 & 5,6 & 18 & 100,0 \\
\hline Altos cargos do gov. federal & 12,5 & 31,2 & 50,0 & 6,3 & 16 & 100,0 \\
\hline Altos cargos de gov. estaduais & 16,1 & 45,2 & 29,0 & 9,7 & 31 & 100,0 \\
\hline Altos cargos de gov. municipais & 25,0 & 62,5 & 12,5 & 0 & 8 & 100,0 \\
\hline Baixo e médio funcionalismos & 66,7 & 33,3 & 0 & 0 & 9 & 100,0 \\
\hline Diretores de bancos estatais & 10,0 & 10,0 & 60,0 & 20,0 & 10 & 100,0 \\
\hline Magistério público superior & 38,5 & 30,8 & 26,9 & 3,8 & 26 & 100,0 \\
\hline Outros professores & 47,7 & 20,5 & 27,3 & 4,5 & 44 & 100,0 \\
\hline Comunicadores & 58,6 & 20,7 & 13,8 & 6,9 & 29 & 100,0 \\
\hline Pastores e padres & 41,2 & 29,4 & 17,6 & 11,8 & 17 & 100,0 \\
\hline $\begin{array}{l}\text { Empregados não manuais de } \\
\text { serviços }\end{array}$ & 63,6 & 27,3 & 9,1 & 0 & 11 & 100,0 \\
\hline $\begin{array}{l}\text { Trabalhadores industriais } \\
\text { qualificados }\end{array}$ & 71,4 & 28,6 & 0 & 0 & 7 & 100,0 \\
\hline Lavradores & 100,0 & 0 & 0 & 0 & 3 & 100,0 \\
\hline Políticos & 33,3 & 0 & 33,3 & 33,4 & 3 & 100,0 \\
\hline Sem informação & 0 & 100,0 & 0 & 0 & 1 & 100,0
\end{tabular}

5. Patrimônio por unidade da Federação

\begin{tabular}{c|c|c|c|c|c}
\multirow{2}{*}{ Estado } & \multicolumn{5}{|c}{ Patrimônio } \\
\cline { 2 - 6 } & Baixo & Médio-baixo & Médio-alto & Alto & Sem inf. \\
\hline AC & 4 & 2 & 1 & 1 & 0 \\
\hline AP & 3 & 3 & 1 & 1 & 0 \\
\hline PA & 5 & 3 & 7 & 2 & 0 \\
\hline RO & 3 & 5 & 0 & 0 & 0 \\
\hline RR & 0 & 3 & 4 & 0 & 1 \\
\hline TO & 0 & 5 & 3 & 0 & 0 \\
\hline AL & 1 & 3 & 2 & 0 & 3 \\
\hline CE & 4 & 6 & 7 & 5 & 0 \\
\hline PE & 4 & 8 & 6 & 7 & 0 \\
\hline PI & 2 & 2 & 4 & 2 & 0 \\
\hline RN & 0 & 3 & 5 & 0 & 0 \\
\hline ES & 2 & 6 & 0 & 1 & 1 \\
\hline MG & 11 & 15 & 18 & 9 & 0 \\
\hline RJ & 22 & 9 & 8 & 7 & 0 \\
\hline SP & 17 & 9 & 27 & 15 & 2 \\
\hline PR & 6 & 7 & 10 & 6 & 1 \\
\hline RS & 10 & 12 & 7 & 2 & 0 \\
\hline SC & 5 & 3 & 7 & 1 & 0 \\
\hline DF & 2 & 1 & 1 & 2 & 2 \\
\hline MT & 5 & 1 & 1 & 0 & 1 \\
\hline MS & 5 & 0 & 1 & 2 & 0 \\
& & & & &
\end{tabular}




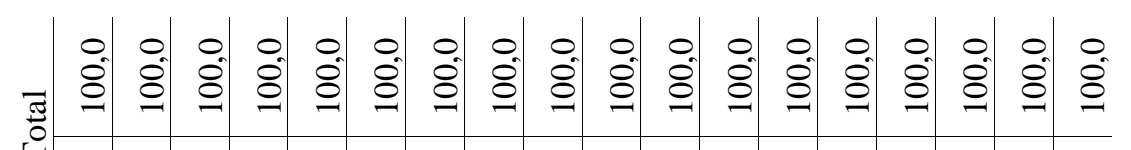

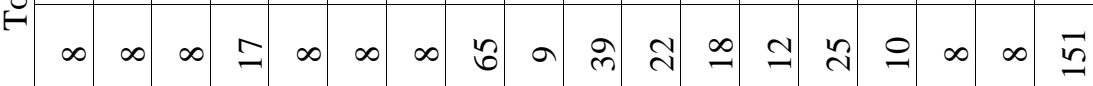
0

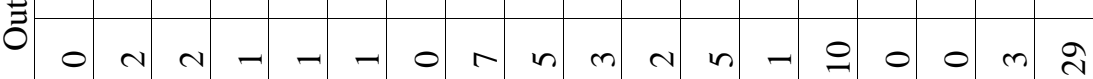

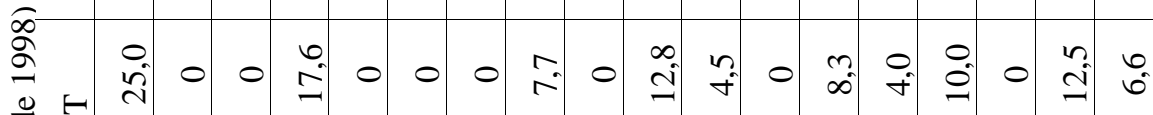

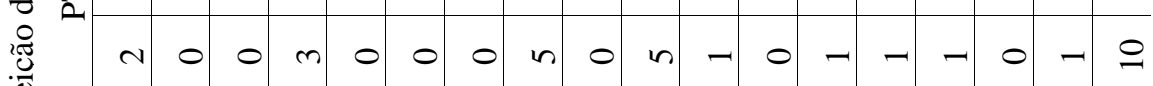
II

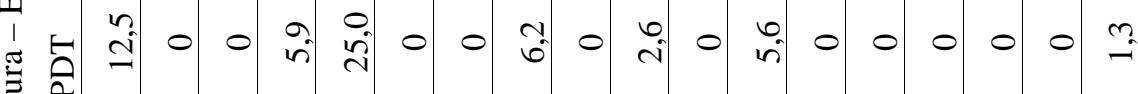
窇

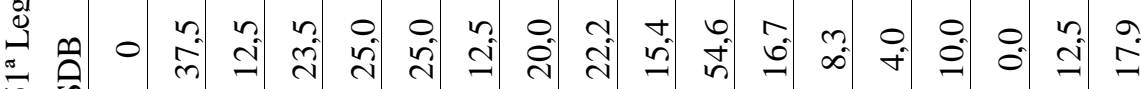

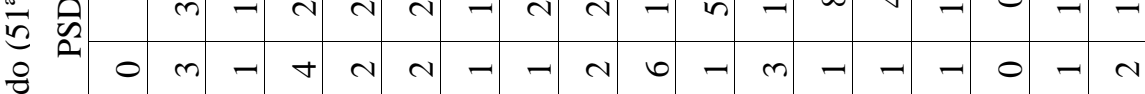

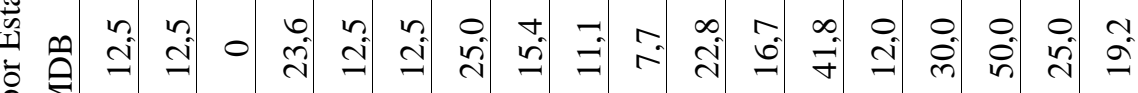

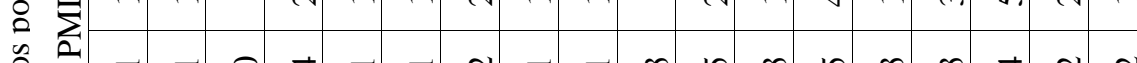

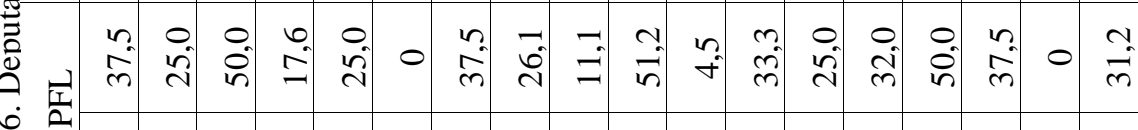

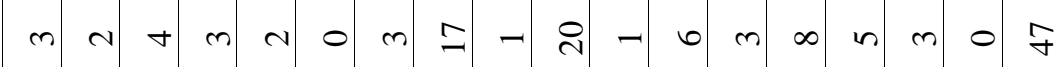

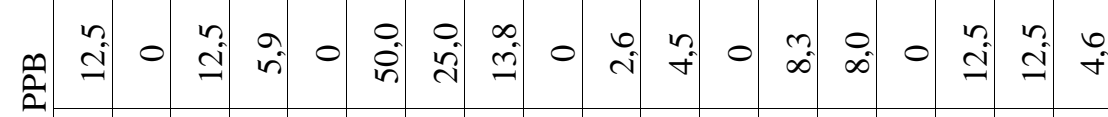

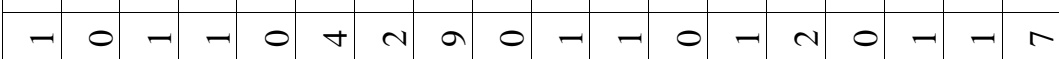

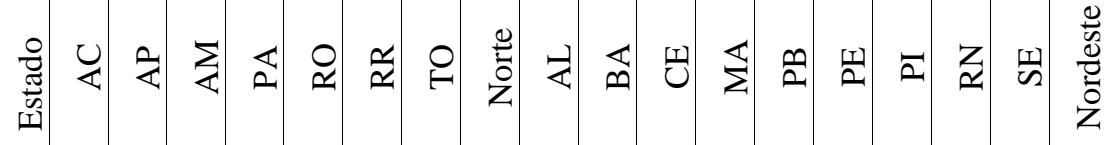

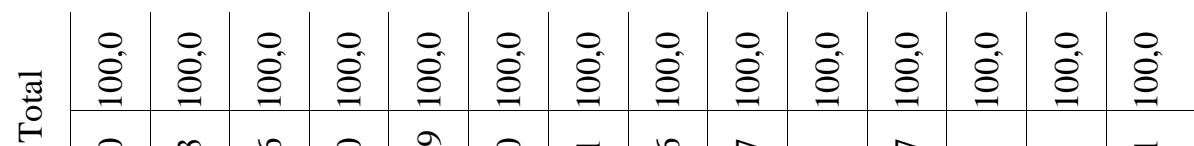

$\because$ 의

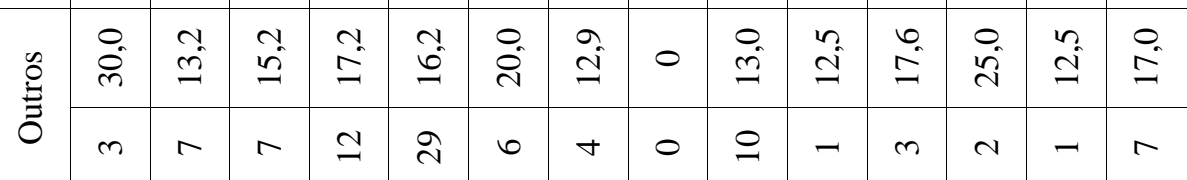

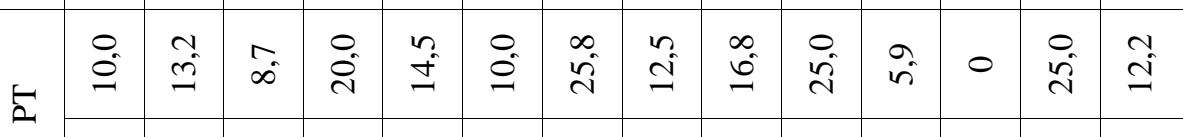

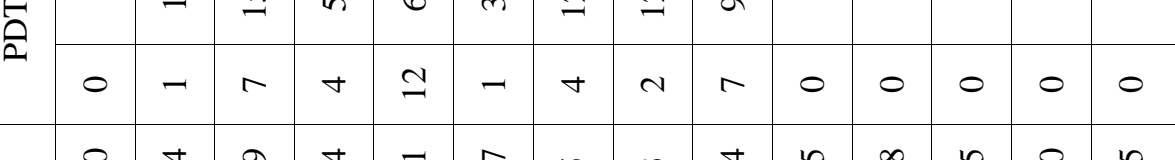

\begin{tabular}{|c|c|c|c|c|c|c|c|c|c|c|c|c|c|c|}
\hline & O̊ & $\begin{array}{l}+ \\
\stackrel{\leftrightarrow}{0}\end{array}$ & ले & $\frac{\vec{\Delta}}{\vec{v}}$ & $\vec{d}$ & $\hat{\sigma}$ & $n$ & ?ֶ. & $\stackrel{\Delta}{\stackrel{\sigma}{0}}$ & $\hat{c}$ & $\stackrel{\infty}{=}$ & $\frac{n}{n}$ & $\begin{array}{l}0 \\
i j\end{array}$ & $\tilde{a}$ \\
\hline & $m$ & $\Xi$ & $=$ & $n$ & $\stackrel{\vartheta}{\forall}$ & $n$ & $\sim$ & - & $\infty$ & - & $\sim$ & $m$ & $\sim$ & $\alpha$ \\
\hline
\end{tabular}

\begin{tabular}{|c|c|c|c|c|c|c|c|c|c|c|c|c|c|c|}
\hline \multirow{2}{*}{$\sum_{0}^{\infty}$} & $\stackrel{0}{0}$ & $\stackrel{\circ}{\cong}$ & $\stackrel{n}{f}$ & $\vec{r}$ & $\tilde{a}^{2}$ & $\stackrel{m}{g}$ & $\begin{array}{l}0 \\
\text { i }\end{array}$ & $\begin{array}{l}0 \\
i\end{array}$ & $\approx$ & $\stackrel{n}{\simeq}$ & $\overrightarrow{\vec{f}}$ & $\stackrel{0}{i}$ & $\stackrel{\sim}{\simeq}$ & $\hat{\text { ̀े }}$ \\
\hline & - & $a$ & $\sim$ & $n$ & 工 & $\nabla$ & $r$ & $\nabla$ & 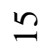 & - & $\infty$ & N & - & $\simeq$ \\
\hline
\end{tabular}

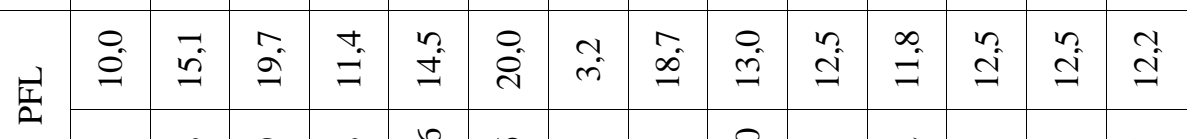

\begin{tabular}{|c|c|c|c|c|c|c|c|c|c|c|c|c|c|c|}
\hline \multirow{2}{*}{$\stackrel{n}{\hat{a}}$} & $\stackrel{0}{0}$ & $\tilde{n}$ & $\stackrel{0}{9}$ & $\stackrel{\Sigma}{\simeq}$ & $\stackrel{n}{ \pm}$ & 6 & $\overline{0}$ & $\begin{array}{l}0 \\
\end{array}$ & $\underset{\infty}{\infty}$ & $\begin{array}{l}0 \\
\text { in }\end{array}$ & $\begin{array}{l}\infty \\
i\end{array}$ & 0 & $\tilde{c}$ & $a^{\infty}$ \\
\hline & - & $r$ & 6 & $\simeq$ & బ้ & $n$ & $n$ & $\nabla$ & $\Xi$ & $N$ & - & 0 & - & $\nabla$ \\
\hline
\end{tabular}

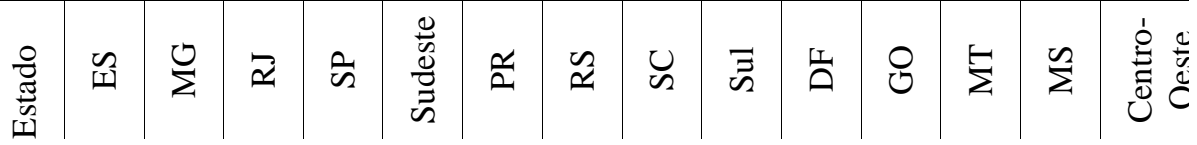


7. Fragmentação e partidos efetivos por Estado

\begin{tabular}{|c|c|c|}
\hline Estado & Fragmentação & Partidos efetivos \\
\hline $\mathrm{AC}$ & 0,75 & 4,0 \\
\hline $\mathrm{AL}$ & 0,86 & 7,3 \\
\hline $\mathrm{AM}$ & 0,68 & 3,2 \\
\hline AP & 0,75 & 4,0 \\
\hline BA & 0,68 & 3,2 \\
\hline $\mathrm{CE}$ & 0,64 & 2,7 \\
\hline DF & 0,81 & 5,3 \\
\hline ES & 0,78 & 4,5 \\
\hline GO & 0,72 & 3,6 \\
\hline MA & 0,81 & 5,2 \\
\hline MG & 0,84 & 6,2 \\
\hline MS & 0,81 & 5,3 \\
\hline MT & 0,75 & 4,0 \\
\hline PA & 0,82 & 5,4 \\
\hline PB & 0,74 & 3,8 \\
\hline PE & 0,77 & 4,3 \\
\hline PI & 0,64 & 2,7 \\
\hline PR & 0,83 & 6,1 \\
\hline RJ & 0,85 & 6,6 \\
\hline $\mathrm{RN}$ & 0,59 & $-,, ;-)$ \\
\hline RO & 0,78 & 4,5 \\
\hline $\mathrm{RR}$ & 0,65 & 2,9 \\
\hline $\mathrm{RS}$ & 0,82 & 5,7 \\
\hline $\mathrm{SC}$ & 0,8 & 5,1 \\
\hline SE & 0,84 & 6,4 \\
\hline SP & 0,85 & 6,9 \\
\hline TO & 0,72 & 3,5 \\
\hline
\end{tabular}

\section{AUTORES CITADOS}

ABRUCIO, Luiz Fernandes (1998). Os Barões da Federação. São Paulo, Hucitec, Departamento de Ciência Política da USP.

ALMEIDA, Maria Hermínia Tavares de \& MOYA, Maurício (1997). "A Reforma Negociada: o Congresso e a Política de Privatização". Revista Brasileira de Ciências Sociais, vol. 12, n. 34.

AMES, Barry \& POWER, Timothy (1990). "Research Guide for Roll-call Voting in Brazil's Constituent Assembly, 1987-1990".

AMES, Barry (1994). "A Organização Partidária Local nas Eleições Presidenciais Brasileiras de 1989". Dados, vol. 37, n. 1, Rio de Janeiro, Iuperj.

(2001). The Deadlock of Democracy in Brazil. Michigan, Michigan University Press.

AMORIM NETO, Octavio (2000). "Gabinetes Presidenciais, Ciclos Eleitorais e Disciplina Legislativa no Brasil". Dados, vol. 43, n. 3, Rio de Janeiro.

ASSIS, Éder Araújo de (1997). "Goiás: Os Partidos, As Eleições e as Transformações Recentes”. In: LIMA JR., Olavo Brasil de (org.). $O$ Sistema Partidário Brasileiro. Rio de Janeiro, Editora Fundação Getúlio Vargas.

AVELAR, Lúcia (1996). As Mulheres na Elite Política Brasileira. Canais de Acesso ao Poder. São Paulo, Konrad-Adenauer-Stiftung, n. 6.

BARTOLINI, Stefano \& MAIR, Peter (1990). Identity, Competition, and Electoral Availability: The Stabilization of European Electorates. Cambrigde. Cambrigde Universtity Press.

BRAGA, Sérgio Soares (1998). Quem foi Quem na Assembleia Constituinte de 1946. Brasília, Centro de Documentação e Informação da Câmara de Deputados, vol. I.

BRIQUET, Jean Louis (1999). "L'Imperatif du changement. Critique de la classe politique et renouvellment des parlamentaire dans la crise 
italienne". In: OFFERLÉ, Michel (org.). La Profession politique $X I X^{e}-X X^{e}$ siècles. Paris, Éd. Belin.

CAMARGOS, Malco Braga \& CARDOSO, Maria das Dores (1997). "Bahia: Formato e Funcionamento do Sistema Partidário". In: LIMA JR., Olavo Brasil de (org.). O Sistema Partidário Brasileiro. Rio de Janeiro, Editora Fundação Getúlio Vargas.

CANÊDO, Letícia Bicalho (1999). "Rites, symboles et allégories dans l'exercice professionnel de la politique". Informations sur les Sciences Sociales, vol. 38, n. 2, Londres, Pages.

(1998). "La Production généalogique et les modes de transmission d'un capital politique familial dans le Minas Gerais brésilien". Genése, n. 31, junho, Paris.

CARVAlHO, José Murilo (1980). A Construção da Ordem. A Elite Política Imperial. Brasília, Universidade de Brasília.

COELHO, Ricardo Corrêa (1999). Partidos Políticos, Maiorias Parlamentares e Tomada de Decisão na Constituinte. São Paulo, tese de doutorado apresentada no Depto. de Ciência Política da FFLCH da Universidade de São Paulo.

COLLOVALD, Annie (1985). "La République du militant. Recrutement et filières de la carrière politique des députés". In: BIRBAUM, Pierre. Les Elites Socialistes au Pouvoir. Paris, PUF.

DINIZ, Eli \& Boshi, Renato (2000). "Globalização, Herança Corporativa e a Representação dos Interesses Empresariais: Novas Configurações no Cenário Pró-reformas". In: Boschi, Renato; DINIZ, Eli \& SANTOS, Fabiano (orgs.). Elites Econômicas e Políticas no Brasil Contemporâneo. São Paulo, Konrad-Adenauer-Stiftung.

DOGAN, Mattei (1999). "Les professions propices à la carrière politique. Osmoses, filières et viviers". In: OFFERLÉ, Michel (org.). La Profession politique XIX ${ }^{e}-X X^{e}$ siècles. Paris, Ed. Belin.

DOWNS, Anthony (1957). An Economic Theory of Democracy. New York, Harper \& Row Publishers.
FERNANDES, Luís (1995). "Muito Barulho por Nada? O Realinhamento Político-Ideológico nas Eleições de 1994”. Dados, vol. 38, Rio de Janeiro, Iuperj.

FIGUEIREDO, Argelina Cheibub \& LIMONGI, Fernando (1994). "O Processo Legislativo e a Produção Legal no Congresso PósConstituinte". Novos Estudos Cebrap, n. 38, março.

(1999). Executivo e Legislativo na Nova Ordem Constitucional. Rio de Janeiro, FGV/Fapesp.

FIGUEIREDO, Marcus \& JORGE, Vladimyr (1997). "S. Paulo. Dinâmica e Formato do Sistema Político". In: LIMA JR., Olavo Brasil de (org.). O Sistema Partidário Brasileiro. Rio de Janeiro, Editora Fundação Getúlio Vargas.

FLEISCHER, David (1981). "O Sistema Partidário Brasileiro". In: FLEISCHER, David (org.). Os Partidos Políticos no Brasil. Brasília, UnB.

FOWLER, Linda L. \& MCCLURE, Robert D. (1989). Political Ambition. Who Decides to Run for Congress. Yale, Yale University Press.

GATTI, Brigitte (1999). "Syndicats des anciens contre 'forces vives' da la Nation. Le renouvellement politique de 1958". In: OFFERLÉ, Michel. La Profession politique XIX ${ }^{e}-X X^{e}$ siècles. Paris, Ed. Belin.

GRAMSCI, Antonio (1968). Maquiavel. A Política e o Estado Moderno. Rio de Janeiro, Civilização Brasileira, 1968.

GROHMANN, Luís Gustavo Melo (1997). "Santa Catarina: Formato e Tendências do Sistema partidário". In: LIMA JR., Olavo Brasil de (org.). O Sistema Partidário Brasileiro. Rio de Janeiro, Editora Fundação Getúlio Vargas.

GUEDÉ, Alain \& ROZEMBLUM, A. (1981). "Les candidats aux élections législatives de 1981". Revue Française de Science Politique.

GUTTSMAN, W. L. (1963). The British Political Elite. New York, Basic Books.

HAGOPIAN, Frances (1996). Traditional Politics and Regime Change in Brazil. Cambridge, Cambridge University Press. 
HERRNSON, Paul (1997). “United States”. In: Norris, Pipa (ed.). Passages to Power. Cambridge, Cambridge University Press.

KECK, Margaret (1991). PT A Lógica da Diferença. O Partido dos Trabalhadores na Construção da Democracia Brasileira. São Paulo, Ática.

KINZO, Maria D’Alva Gil (1993). Radiografia do Quadro Partidário Brasileiro. São Paulo, Konrad-Adenauer-Stiftung.

. Oposição e Autoritarismo. Gênese e Trajetória do MDB (19661979). São Paulo, Idesp/Vértice.

KIRCHHEIMER, Otto (1966). "The Transformation of the Western European Party Systems". In: LAPALOMBARA, Joseph \& WEINER, Myron (eds.). Political Parties and Political Development. Princeton, Princeton University Press.

LAMOUNIER, Bolívar (1989). Partidos e Utopias. O Brasil no Limiar dos Anos 90. São Paulo, Edições Loyola.

LAMOUNIER, Bolívar \& MENEGUELLO, Rachel (1986). Partidos Políticos e Consolidação Democrática. O Caso Brasileiro. São Paulo, Brasiliense.

LAMOUNIER, Leonardo Alves (1997). "Minas Gerais. O Sistema Partidário nas Duas Últimas Décadas". In: LIMA JR., Olavo Brasil de (org.). O Sistema Partidário Brasileiro. Rio de Janeiro. Editora Fundação Getúlio Vargas.

LIMA JR., Olavo Brasil de (1993b). Democracia e Instituições Políticas no Brasil dos Anos 80. Rio de Janeiro, Edições Loyola.

(1997). "A Reimplantação do Multipartidarismo: Efeitos Institucionais e Contextuais". In: LIMA JR., Olavo Brasil de (org.). O Sistema Partidário Brasileiro. Rio de Janeiro, Editora Fundação Getúlio Vargas.

. (1983). Partidos Políticos Brasileiros. Rio de Janeiro, Graal.

(1993a). "A Reforma das Instituições Políticas: A Experiência Brasileira e o Aperfeiçoamento Democrático". Dados, vol. 36, n. 1, Rio de Janeiro.
LIMONGI, Fernando \& FIGUEIREDO, Argelina Cheibub (1995). "Partidos Políticos na Câmara dos Deputados: 1989-1994". Dados, vol. 38 , n. 3 .

(1998). "Bases Institucionais do Presidencialismo de Coalizão". Lua Nova, n. 44, São Paulo, Cedec.

LOENBERG, Gerhard \& PATTERSON, Samuel C. (1979). Comparing Legislatures. Boston, Little, Brown and Company.

MACKIE, Thomas T. \& ROSE, Richard (1991). The International Almanac of Electoral History. Londres, MacMillan.

MAINWARING, Scott \& LIÑAN, Aníbal Pérez. (1998). "Disciplina Partidária: O Caso da Constituinte". Lua Nova, n. 44, São Paulo, Cedec.

(1993). "Democracia Presidencialista Multipartidária: o Caso do Brasil”. Lua Nova, n. 28/29, São Paulo, Cedec.

(1995). "Brazil. Weaks Parties, Feckless Democracy". In: MAINWARING, Scott \& SCULLY, Timothy R. (eds.). Building Democratic Institutions. Party Systems in Latin America. Stanford, Stanford University Press.

Rethinking Party Systems in the Third Wave of Democratization. The Case of Brazil. Stanford, Stanford University Press.

MAINWARING, Scott; MENEGUELLO, Rachel \& POWER, Timothy (2000). Partidos Conservadores no Brasil Contemporâneo. São Paulo, Paz e Terra.

MAINWARING, Scott P. \& SCULLY, Timothy R. (1994). "A Institucionalização dos Sistemas Partidários na América Latina". Dados, vol. 37, n. 1, Rio de Janeiro.

MARQUES, Jales Ramos \& FLEISCHER, David (1999). PSDB - de Facção a Partido. Brasília, Instituto Teotônio Vilela, Gráfica e Editora Positiva.

MCALLISTER, Ian (1997). “Australia”. In: NORRIS, Pipa (ed.). Passages to Power. Cambridge, Cambridge University Press. 
MELHEM, Célia Soilbelmann (1998). Política de Botinas Amarelas. O MDB-PMDB Paulista de 1965 a 1988. São Paulo, Hucitec/ Departamento de Ciência Política da USP.

MELO, Carlos Ranulfo Felix de (1999). Retirando as Cadeiras do Lugar: Migração Partidária na Câmara dos Deputados (1985-1998). Tese de doutorado apresentada em Ciências Humanas, Sociologia e Política da Universidade Federal de Minas Gerais (mimeo.).

(2000). "Partidos e Migração Partidária na Câmara de Deputados". Dados, vol. 43, n. 2, Rio de Janeiro, Iuperj.

MENEGUELLO, Rachel (1998). Partidos e Governos no Brasil Contemporâneo (1985- 1997). São Paulo, Paz e Terra.

. PT. A Formação de um Partido, 1979-1982. Rio de Janeiro, Paz e Terra.

MICHELS, Robert (1924). Il Partito Político nella Democrazia Moderna. Torino, Unione Tipográfico-Editrice Torinese.

MONCLAIRE, Stéphane \& BARROS FILHO, Clóvis (1998). A Política da Constituinte. Brasília, Instituto Tancredo Neves.

MONCLAIRE, Stéphane (1991). "Les Auteurs de la Constitution". In: MAUS, Didier \& BON, Pierre (orgs.) et al. La Nouvelle république bresilienne. Paris, Economica.

MONCLAIRE, Stéphane (1992). "Répresentés, répresentants et represéntations au Brésil". In: COUFFIGNAL, Georges (org.). Réinventer la démocratie. Paris, Presses de la Fondation Nationales des Sciences Politique.

MORAES FILHO, José Filomeno de (1997). "Ceará. O Subsistema Partidário e o Retorno ao Pluripartidarismo". In: LIMA JR., Olavo Brasil de (org.). O Sistema Partidário Brasileiro. Rio de Janeiro, Editora Fundação Getúlio Vargas.

NICOLAU, Jairo (1993). Sistema Eleitoral e Reforma Política. Rio de Janeiro, Foglio.

(1997). "Notas Sobre os Quatro Índices mais Utilizados nos Estudos Eleitorais". In: LIMA JR., Olavo Brasil de (org.). O Sistema
Partidário Brasileiro. Rio de Janeiro, Editora Fundação Getúlio Vargas.

(2000). "Disciplina Partidária e Base Parlamentar na Câmara dos Deputados no Primeiro Governo Fernando Henrique Cardoso (19951998)". Dados, vol. 43, n. 4, Rio de Janeiro, Iuperj.

(1996). Multipartidarismo e Democracia. Rio de Janeiro, Editora Fundação Getúlio Vargas.

(org.) (1998). Dados Eleitorais do Brasil (1982-1996). Rio de Janeiro, Iuperj/Ucam/Editora Revan.

NOHLEN, Dieter (1994). Sistemas Electorales y Partidos Políticos. México, Universidad Nacional Autónoma de México/Fondo de Cultura Económica.

NORRIS, Pipa \& LOVENDUSKI, Jones (1997). "United Kingdon”. In: NORRIS, Pipa (ed.). Passages to Power. Legislative Recruitment in Advanced Democracies. Cambridge, Cambridge University Press.

(1995). Political Recruitment: Race, Gender and Class in British Parliament. Cambridge, Cambridge University Press.

(1996). "Legislative Recruitment". In: LEDUC, Lawrence; NIEMI, Richard \& NORRIS, Pipa (eds.). Comparing Democracies. Elections and Voting in a Global Perspective. California, Sage, cap. 7.

NOVAES, Carlos Alberto (1993). "PT: Dilemas da Burocratização". Novos Estudos Cebrap, 35 (março).

(1994). "Dinâmica Institucional de Representação", Novos Estudos Cebrap 38. São Paulo, março.

PANEBIANCO, Ângelo (1988). Political Parties: Organization and Power. Cambridge, Cambridge University Press.

PEDERSEN, Mogens (1990). "On Measuring Party Systems Change: A Methodological Critique and Suggestions". Comparative Political Studies, n. 12, vol. 4. 
(1980): "Electoral Volatility in Western Europe: 1948-1977". In: MAIR, Peter (ed.): The West Europe Party System. Oxford, Oxford University Press.

PERES, Paulo Sérgio (2000). O Sistema Partidário Brasileiro e o Espectro da Instabilidade. São Paulo, dissertação de mestrado aprovada no Programa de Pós-Graduação do Departamento de Ciência Política da USP (mimeo.).

RADICE, Lisanne; VALLANCE, Elizabeth \& WILLIS, Virginia (1987). Member of Parliament. The Job of a Backbencher. Londres, St. Martin's Press.

RAE, Douglas (1971). The Political Consequences of Electoral Laws. $2^{\mathrm{a}}$ ed., New Haven/Londres, Yale University Press.

ROBERTS, Geoffrey (1988). "German Federal Republic: Two-Lane route to Bonn". In: GALLAGHER, Michael \& MARSH, Michael (eds.). Candidate Selection in Comparative Perspective. The Secret Garden of Politics. Londres, Sage.

RODRIGUES, Leôncio Martins (1990). "A Composição Social da Liderança do PT”. In: São Paulo, Ática.

(1997). "PT: A New Actor in Brazilian Politics". In: DEVOTO, Fernando J. \& DI TELLA, Torcuato (eds.). Political Culture, Social Movements and Democratic Transitions in South America in the Twentieth Century. Milão, Fondazione Giangiacomo Feltrinelli, Feltrinelli Editore.

(1987). Quem é Quem na Constituinte. Uma Análise Sociopolítica dos Partidos e Deputados. São Paulo, Oesp-Maltese.

(1990). "A Composição Social da Liderança do PT". Partidos e Sindicatos. São Paulo, Ática.

(1995). “As Eleições de 1994: Uma Apreciação Geral”. Dados, vol. 38 , n. 1 .

. (1999). Destino do Sindicalismo. São Paulo, Edusp.

RUSH, Michael (1969). The Selection of Parliamentary Candidates. Londres, Thomas Nelson and Sons Ltd.
SAMUELS, David (1996). Legislative Liliputians? Toward a Theory of Party Cohesion in the Brazilian Chamber of Deputies. Comunicação preparada para a Reunião Anual da Associação Americana de Ciência Política de 29 de agosto a 1 de setembro de 1996.

(1997). "Determinantes do Voto Partidário em Sistemas Eleitorais Centrados no Candidato: Evidências sobre o Brasil". Dados, vol. 40, n. 3, Rio de Janeiro, Iuperj.

SANTOS, André Marenco dos (1997). "Nas Fronteiras do Campo Político: Raposas e Outsiders no Congresso Nacional". Revista Brasileira de Ciências Sociais, n. 33, fevereiro.

(2000). Não se Fazem mais Oligarquias como Antigamente. Recrutamento Parlamentar, Experiência Política e Vínculos Partidários entre Deputados Brasileiros [1946-1998]. Porto Alegre, tese de doutorado apresentada no PPG de Ciência Política da UFRGS.

(2001). "Sedimentação de Lealdades Partidárias no Brasil: Tendências e Descompassos". Revista Brasileira de Ciências Sociais, vol. 16, n. 45, fevereiro.

SANTOS, Fabiano (2000). "Deputados Federais e Instituições Legislativas no Brasil: 1946-99”. In: BOSCHI, Renato; DINIZ, Eli \& SANTOS, Fabiano. Elites Políticas e Econômicas no Brasil Contemporâneo. São Paulo, Fundação-Konrad-Adenauer.

SARTORI, Giovanni (1982). Partidos e Sistemas Partidários. Brasília, Zahar Editores/Editora da Universidade de Brasília.

SCHMITT, Rogério (1998). Coligações Eleitorais e Sistema Partidário no Brasil. Rio de Janeiro, tese de doutorado apresentada e aprovada no Iuperj (mimeo.).

(1999). "Migração Partidária e Reeleição na Câmara dos Deputados" Novos Estudos Cebrap, vol. 54, julho.

(1997). "Rio de Janeiro. Multipartidarismo, Competitividade e Realinhamento Eleitoral". In: LIMA JR., Olavo Brasil de (org.). $O$ Sistema Partidário Brasileiro. Rio de Janeiro, Editora Fundação Getúlio Vargas. 
SHUMPETER, Joseph A. (1961). Capitalismo, Socialismo e Democracia. Rio de Janeiro, Editora Fondo de Cultura ( $1^{a}$ ed. americana: 1942).

SILVA, João Carlos da (2002). Empresários na Câmara de Deputados (1999-2003). Recrutamento, Ascensão e Trajetória Política. Dissertação de mestrado defendida no Departamento de Ciência Política da Unicamp (mimeo.).

SINGER, André (1999). Esquerda e Direita no Eleitorado Brasileiro. São Paulo, Edusp/Fapesp.

SOARES, Gláucio Ary Dillon (1973). Sociedade e Política no Brasil. São Paulo, Difusão Europeia do Livro.

TAVARES, José Antônio Giusti (1997). "Rio Grande do Sul: O Sistema Eleitoral e Parlamentar". In: LIMA JR., Olavo Brasil de (org.). $O$ Sistema Partidário Brasileiro. Rio de Janeiro, Editora Fundação Getúlio Vargas.

THIÉBAULT, Jean-Louis (1988). "France: Impact of Electoral System Change". In: GALLAGHER, Michael \& MARSH, Michael. Candidate Selection in Comparative Perspective. The Secret Garden of Politics. Londres, Sage.

VON BEYME, Klaus (1983). The Political System of the Federal Republic of Germany. New York, St. Martin's.

WEBER, Max (1964). "La Instituición Estatal Racional y los Partidos Políticos y Parlamentos Modernos (Sociologia del Estado)". In: Economia y Sociedad. Ciudad de México, Fondo de Cultura Económica, vol. II, cap. IX, (1ª ed. alemã: 1922).

WERTMAN, Douglas A. (1988). "Italy: Local Involvement, Central Control". In: GALLAGHER, Michael \& MARSH, Michael. Candidate Selection in Comparative Perspective. The Secret Garden of Politics. Londres, Sage.

WESSELS, Bernhard (1997). “German”. In: NORRIS, Pipa (1997) (ed.). Passages to Power. Cambridge, Cambridge University Press.

WINTER, De Lieven (1988). “Belgium: Democracy or Oligarchy?”. In: GALLAGHER, Michael \& MARSH, Michael. Candidate Selection in Comparative Perspective. The Secret Garden of Politics. Londres, Sage.

Outros documentos

“OLHO no Congresso”. (1998). Folha de S. Paulo,

Especial.

“OLHO no Voto”. (1994). Folha de S. Paulo, Especial.

“PERFIL Parlamentar Brasileiro”. (1991). Istoé/Senhor/Editora Três. 